UNIVERSIDADE DE SÃO PAULO

FACULDADE DE FILOSOFIA, LETRAS E CIÊNCIAS HUMANAS

DEPARTAMENTO DE HISTÓRIA

PROGRAMA DE PÓS-GRADUAÇÃO EM HISTÓRIA SOCIAL

\title{
A NARRATIVA DA ORDEM E A VOZ DA MULTIDÃO: \\ O FUTEBOL NA IMPRENSA DURANTE O ESTADO NOVO
}

(1937-1945)

Melina Nóbrega Miranda Pardini

Dissertação apresentada ao Programa de Pós-Graduação em História Social do Departamento de História da Faculdade de Filosofia, Letras e Ciências Humanas da Universidade de São Paulo, para a obtenção do título de Mestre em História.

Orientador: Prof. Dr. Flavio de Campos

São Paulo 
Com amor, ao meu querido José Rafael.

- 2 - 


\section{AGRADECIMENTOS}

Meu primeiro contato com o professor doutor Flávio de Campos ocorreu logo no segundo ano da minha graduação em História, na Faculdade de Filosofia, Letras e Ciências Humanas da Universidade de São Paulo. A despeito de eu não fazer parte de nenhum programa oficial de iniciação científica, desde a nossa primeira conversa ele tornou-se o meu orientador nessa empreitada, auxiliando-me a realizar o projeto de pesquisa que, posteriormente, seria a chave para eu entrar no programa de pósgraduação em História Social.

Assim, sou muito grata ao professor Flávio que, além de ter endossado a minha entrada no programa de pós-graduação, indicou-me os rumos da pesquisa de mestrado, foi compreensível nos difíceis momentos pelos quais passei durante essa empreitada e ensinou-me a superar tanto os obstáculos teórico-metodológicos do estudo, como aqueles intrínsecos à própria vida.

Ao professor doutor Waldenyr Caldas, com quem tive o primeiro contato através da leitura das suas obras sobre futebol e, posteriormente, quando assisti às suas aulas na Escola de Comunicação e Artes, da Universidade de São Paulo, meu sincero agradecimento por ter aceitado o convite de ser membro da banca de qualificação dessa dissertação.

À professora doutora Zilda Márcia Grícoli Yokoi que igualmente aceitou participar da qualificação desse trabalho, meu muito obrigada. Amiga desde os primeiros anos da graduação, a professora Zilda foi a pessoa que me monstrou o papel social do historiador e de suas pesquisas. Sinceramente, espero com esse trabalho ajudar a colocar mais um tijolo no muro do conhecimento, por menor que ele seja. 
Muito obrigada ao professor doutor Hilário Franco Junior pelo convite para assistir às suas aulas sobre futebol na pós-graduação, ainda quando eu sequer tinha me graduado, fato que se revelou uma grande oportunidade para eu me aprofundar na bibliografia sobre o assunto, conhecer outros estudiosos e profissionais do futebol.

Sou igualmente grata ao professor doutor da Universidade Federal do Rio de Janeiro, Victor Andrade de Melo, e aos demais membros do Laboratório de História do Esporte e do Lazer que tão bem me receberam durante o encontro regioanal da ANPUH, em 2006 (especialmente ao André Maia Schetinov, que tanto me auxiliou durante o período em que fiquei pesquisando na Biblioteca Nacional, no Rio de Janeiro). Aproveito para agradecer aos professores doutores da Universidade Federal Fluminense, Márcio Piñon de Oliveira e Cláudia Alves, que gentilmente me hospedaram em sua casa em Niterói, durante o encontro regional da Associação Nacional dos Professores Universitários de História (ANPUH), em 2006.

Outro professor que me auxiliou nessa empreitada e, por isso sou extremanente grata, foi o professor doutor da Universidade Federal de São Carlos, Luíz Henrique de Toledo. Muito obrigada, Kike, pelas conversas sobre futebol, por ter lido o meu projeto de mestrado e por ter deferido a minha entrada como aluna especial em suas aulas, durante o primeiro semestre de 2007.

Sou igualmente grata aos colegas do Grupo Interdisciplinar de Estudos sobre o Futebol (GIEF) do qual fiz parte entre os anos 2005-2007. Nossas reuniões, discussões bibliográficas, realizações de eventos e publicações de textos, sem dúvida alguma, foram de extrema importância para a realização desse trabalho. Muito obrigada Sérgio Settani Giglio, Enrico Spaggiari, João Paulo Streapco, Fernando, Paulo, Diana Mendes 
Machado da Silva, Julyane, Marco Antunes de Lima, Marcel Diego Tonini e demais membros que entraram posteriormente no GIEF.

Aos queridos amigos da época de graduação - Lucas, Edgar, Carol, Michelle, Vanessa, Camila entre outros que sempre estiveram ao meu lado nessa empreitada meu eterno obrigada. Para finalizar, registro o meu especial agradecimento a minha família, que mesmo longe sonhou a realização desse trabalho juntamente comigo. 
APRESENTAÇÃ

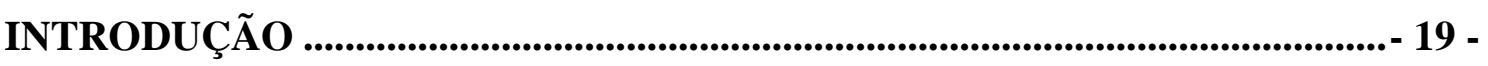

1 A DOMESTICAÇÃO DO CORPUS SOCIAL..................................................... 35

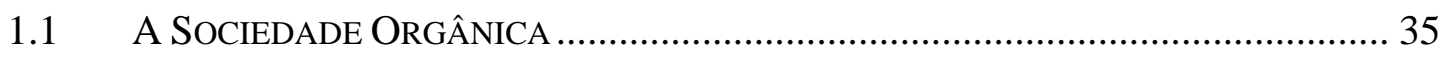

1.2 O ALIMENTO DO ORGANISMO SOCIAL........................................................... 49

2 OS TRABALHADORES DA BOLA .............................................................. 76

2.1 PADRONIZAÇÃO DE HERÓIS ........................................................................ 76

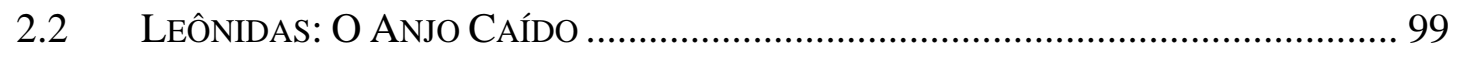

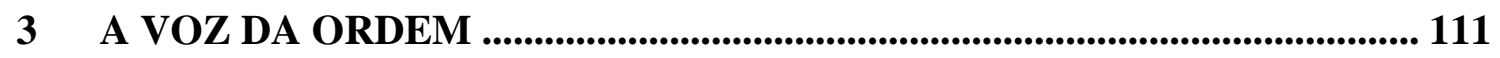

3.1 NAS ENTRELINHAS DO PODER ……………………………………….... 111

3.2 A CRôNICA ESPORTIVA POR MAZZONI E MÁRIo FILHO .................................... 124

4 NAS ARQUIBANCADAS................................................................................ 161

4.1 A AsSISTÊNCIA DA NAÇÃO......................................................................... 161

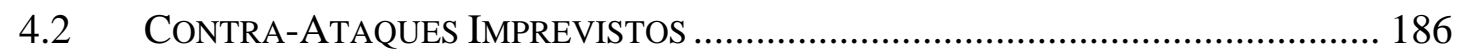

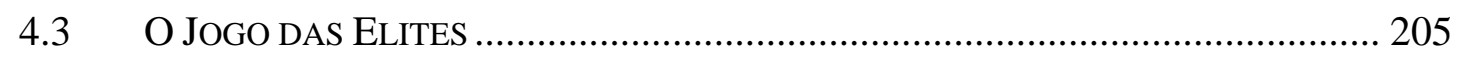

CONSIDERAÇÕES FINAIS.................................................................................. 217

BIBLIOGRAFIA CONSULTADA _................................................................... 220 


\section{RESUMO}

Essa dissertação objetivou analisar como o futebol de São Paulo e do Rio de Janeiro foi utilizado pelo Estado Novo para concretizar o seu projeto de construir uma nação ordenada e disciplinada, afim com os valores produtivos próprios do capitalismo e com o projeto de unidade nacional pensado pelo regime.

Analisando-se os principais periódicos e jornais especializados em esportes desses dois estados, vislumbrou-se como o futebol auxiliou na concretização de alguns ideais engendrados no período estadonovista e, ao mesmo tempo, através do seu aspecto ritualístico, desafiou alguns princípios caros ao Estado Novo.

Palavras-chaves: Estado Novo, Futebol, Imprensa, Nacionalismo e Regionalismo.

\section{ABSTRACT}

This dissertation aimed to analise how soccer in São Paulo and Rio de Janeiro was used by the government to achieve the project of building an ordered and organized nation, connected to the capitalism productive values and to the project of national unity thought by the regime.

Analysing the main periodicals and newspapers specialized in sports of both states it was possible to understand how this sport, through its ritual aspects, helped building the ideal nation planned during this period and, meanwhile, challenged some of the priciples within the regime.

Key words: Estado Novo, Soccer, Press, Nationalism and Regionalism. 
"O colega esvazia o futebol como um pneu, e repito: retira do futebol tudo o que ele tem de misterioso e patético. A mais sórdida pelada é de uma complexidade shakesperiana. Ás vezes, num córner mal ou bem batido, há um toque evidentíssimo do sobrenatural. (...) Se o jogo fosse só a bola, está certo. Mas há o ser humano por trás da bola, e digo mais: a bola é um reles, um ínfimo, um ridículo detalhe. $\mathrm{O}$ que procuramos no futebol é o drama, é a tragédia, é o horror, e a compaixão". RODRIGUES, Nelson. 


\section{APRESENTAÇÃO}

Nelson Rodrigues identificou no futebol a beleza do imponderável, a expressão dos dramas e alegrias da vida. Essa magia, cotidianamente vivenciada pelos diferentes participantes desse esporte, permite seu estudo como algo muito além de um simples jogo com bola, pois ela confere outros significados para os seus atores e legitima os sentimentos provocados em seus aficcionados.

Graças a essas características fascinantes, os jogos foram objetos de diversas reflexões nas ciências sociais. Nesse sentido, tentou-se compreender o futebol em seu aspecto ritualístico, como ele foi utilizado politicamente em diversas sociedades, seu poder gregário, sua influência social e seu aspecto econômico e globalizado. Além disso, inúmeras tentativas de classificá-los foram realizadas, como aquelas que levam em consideração o número de jogadores envolvidos ou os instrumentos necessários para jogar.

Para Caillois, por exemplo, a fim de melhor compreender o significado do jogo para seus participantes, os jogos deveriam ser classificados da seguinte forma: os jogos de competência, presentes como o esporte (agon) propriamente dito; os de imitação, representados pelos espetáculos (mimicry); os de azar e imitação (alea) e os jogos onde prevalecem o transe e a vertigem (ilinx) ${ }^{1}$.

Ainda de acordo com essa classificação, as categorias de jogos se aproximariam, em diferentes intensidades, de duas extremidades analíticas, a saber: os

\footnotetext{
${ }^{1}$ CAILLOIS, Roger. Los juegos y los hombres. La máscara y el vértigo. México: Fondo de Cultura Económica, 1986. p. 41.
} 
jogos livres (paidia) e os jogos regrados (ludus) ${ }^{2}$. Porém, o próprio autor confirmou a fluidez dessa divisão analítica ao descrever a possibilidade de classificar, ao mesmo tempo, a essência do jogo em mais de uma categoria ${ }^{3}$.

Assim, de acordo com as características do jogo de futebol, seria possível associá-lo com o agon, ou seja, esporte regrado onde deve vencer a equipe com maior competência, cujo pré-requisito inicial consiste na igualdade entre os participantes.

Porém, uma partida de futebol igualmente apresenta características próprias da mimicry, como a fuga da realidade quando o torcedor deixa de se apresentar como cidadão e passa a se comportar como um aficcionado por determinado clube realizando atos que, possivelmente, jamais faria se não agisse como torcedor.

Outra aproximação possível de se realizar com o futebol agon seria com a presença do imponderável, da sorte ou destino, presente na alea. Jogadores e torcedores rezam para diferentes credos a fim de trazer a sorte consigo. Uma decisão do juiz pode alterar a dinâmica do jogo e definir o resultado da partida ou do torneio. O próprio fato de, graças ao sorteio, ter que decidir o campeonato no campo do adversário pode ser considerado um mau agouro.

Por fim, no futebol como agon, pode-se encontrar o transe, próprio da ilinx, nos momentos nos quais o artilheiro marca um gol importante e a sua emoção contagia toda a massa torcedora, criando um só sentimento de loucura, com ambos se descolando da realidade e aproveitando intensamente aquele momento de prazer. Ou seja, o futebol agon tem, inicialmente, maior intimidade com o ludus mas, por diversas vezes, se aproxima ternamente da paidia.

\footnotetext{
${ }^{2}$ Idem. Ibidem. pp. 41-42.

${ }^{3}$ Idem. Ibidem. p. 145.
} 
Essas diferentes nuances que compõem um jogo competitivo como o futebol ocorrem graças às qualidades ritualísticas presentes em sua estrutura que reforçam o aspecto lúdico e demarcam o fato de, em princípio, o jogador agir unicamente pelo prazer de jogar, ou seja, do significado do jogo encontrar-se em sua própria prática ${ }^{4}$.

Essas características próprias do rito, presentes nos jogos, seriam a existência de regras próprias e definidoras da sua ordenação, o fato de ele ocorrer em um espaço e temporalidade própria provocando a evasão na vida real e a existência de uma liberdade que não deprecia a seriedade nele contida ${ }^{5}$.

Nesse sentido, ao analisar os diferentes modos de praticar o futebol, Arlei Damo elucidou que, apesar do aspecto lúdico e as características ritualísticas próprias do jogo se apresentarem em diferentes intensidades, variando de acordo com cada forma de jogar, esses elementos sempre se encontram presentes.

Para o autor, os jogos pertencentes à matriz bricolada apresentam o aspecto lúdico em toda sua potencialidade, apesar de não perder a seriedade própria do rito. Essa matriz representaria o tempo social do não trabalho, do lazer, recreação e ócio. Como exemplos dessa matriz destacam-se o futebol praticado na rua, os jogos de polícialadrão, de pega-pega, entre outros ${ }^{6}$.

A matriz comunitária explicaria o futebol de várzea no qual o jogo se apresenta com elementos de espetáculo, mas de modo precário. O futebol praticado nas aulas de Educação Física seria, de acordo com o autor, enquadrado na matriz escolar,

\footnotetext{
${ }^{4}$ HUIZINGA, Johan. Homo Ludens. O jogo como elemento da cultura. $5^{\circ}$ ed. São Paulo: Perspectiva, 2005. pp. 4-5.

${ }^{5}$ Idem. Ibidem. pp. 10-13.

${ }^{6}$ DAMO, Arlei Sander. Do dom à profissão. Formação de futebolistas no Brasil e na França. São Paulo: Aderaldo \& Rothschild Editores/ Anpocs, 2007. p. 40.
} 
diferenciando-se do futebol brincado durante o recreio, cujas características seriam de um jogo bricolado ${ }^{7}$.

Ainda pensando nas categorias de “futebóis” formuladas por Damo, o futebol profissional presente no período pesquisado, faria parte da matriz espetacularizada, na qual existe uma divisão social do trabalho dentro e fora dos gramados e a exigência, efetivada por todos seus participantes, de se realizar uma boa performance ${ }^{8}$.

De acordo com o autor gaúcho, o fato de prevalecer o aspecto competitivo no futebol espetacularizado não diminui o seu aspecto ritualístico, próprio das características inerentes ao jogo. Ao contrário, sua influência como rito público e cotidiano se potencializa com a presença da figura clubística, pois a possibilidade de se ganhar ou perder com o time vinculado a um clube que representa uma comunidade afetiva, faz milhares de pessoas tornarem-se torcedores e, assim, personagens do rito futebolístico ${ }^{9}$.

Assim, ao serem analisadas as diferentes práticas futebolísticas conceituadas por Damo, percebe-se como os jogos, por diversas vezes, aparecem como "fluxos de jogos”, ou seja, eles ocorrem sem programação prévia, em meio a acontecimentos sociais e fatos indetermindados, sempre exercendo certa influência nos indivíduos e grupos sociais, ainda que a sua função e utilidade, a priori, sejam desconhecidas e obscuras $^{10}$.

Apesar de o aspecto agonístico presente no futebol, em que o espírito de

\footnotetext{
${ }^{7}$ Idem. Ibidem. pp. 45-47.

${ }^{8}$ Idem. Ibidem. p. 43.

${ }^{9}$ Idem. Ibidem. p. 49.

${ }^{10}$ DUVIGNAUD, J. El juego del juego. México: Fundo de Cultura Econômica, 1982. p. 88.
} 
competição se destaca, o elemento lúdico encontra-se sempre imbricado na prática esportiva e confere outras experiências a seus participantes além do aspecto competitivo $^{11}$.

Somente se considerado o jogo de futebol como rito, torna-se possível compreender-se a “complexidade shakesperiana” presente em uma partida de futebol, muito bem destacada por Nelson Rodrigues, na qual a presença do drama faz extrapolar a sua imagem de uma atividade de vinte e dois homens correndo atrás de uma bola, concebendo-o como uma atividade capaz de proporcionar outros significados aos particiantes $^{12}$.

Conforme anunciado na epígrafe, a presença do drama constitui-se fundamental para a existência do rito. Para DaMatta, ao dramatizar chama-se a atenção para valores e ideologias que, de maneira diversa, não poderiam ser isolados das rotinas que formam a vida diária ${ }^{13}$. Sobre a função social do rito, o autor escreveu:

\footnotetext{
“O rito, como elemento privelegiado de fazer tomar consciência do mundo, é o veículo básico na transformação de algo natural em algo social. Isso porque para que essa transformação do natural ao social possa ocorrer, uma forma qualquer de dramatização é necessária. E é pela dramatização que tomamos consciência das coisas e passamos a vê-las como tendo um sentido, vale dizer, como sendo sociais” 14 .
}

\footnotetext{
${ }^{11}$ HUIZINGA, Johan. Op. cit., p. 56.

${ }^{12}$ Essa concepção do futebol profissional como ritual cotidiano da sociedade se afasta do conceito de jogo formulado por Huizinga para o qual os esportes seriam jogos profanos, dessacralizados, sem ligação orgânica com a estrutura social. Para esse autor, o espírito profissional presente no esporte, graças à falta de espontaneidade e despreocupação, retira o caráter lúdico próprio do jogo. HUIZINGA, Johan. Op. cit., pp. 219-220.

13 DAMATTA. Roberto (Org). Universo do Futebol. Esporte e sociedade brasileira. Rio de Janeiro: Pinakotheke, 1982. p. 21.

${ }^{14}$ Idem. Carnavais, malandros e heróis. Para uma sociologia do dilema brasileiro. $4^{\circ}$ ed. Rio de Janeiro: Zahar Editores, 1983. p. 29.
} 
Nesse sentido, o futebol constitui-se como drama social, ou seja, elemento básico de uma ritualização cotidiana nessa sociedade, sintetizador das formas de se relacionar, dos valores ou ideologias ${ }^{15}$. Pensada dessa forma, a atividade futebolística permite analisar um determinado fato histórico através do estudo da sua dinâmica e dos vários discursos engendrados ao seu redor:

“... o jogo está na sociedade tanto quanto a sociedade no jogo. Ambos se expressam mutuamente, sendo que suas relações muito complexas [sic]. Deste modo, pode-se dizer que cada sociedade tem o futebol que merece, pois ela o molda e projeta nele um conjunto de temas que lhe são básicos” 16 .

Assim, com a pesquisa de mestrado, compreendeu-se o futebol como expressão social, que por assim o ser, foi também utilizado - mas, não somente - como elemento de manipulação política. Essa concepção do futebol como ritual público e cotidiano contraria posicionamentos como o assumido por Juan Sebreli, para o qual o jogo de futebol como reflexo social favoreceria o fanatismo e a violência, ao mesmo tempo em que contribuiria com a conservação da ordem estabelecida ${ }^{17}$.

Para o autor argentino, o futebol seria um jogo próprio dos baixos setores sociais, pois, para ser um bom jogador de futebol constitui-se necessário saber enganar - arte própria de meninos pobres, sem educação e estrutura familiar, que desde a infância são treinados para mentir, aprontar travessuras e roubar ${ }^{18}$. Assim, de acordo

\footnotetext{
${ }^{15}$ Para Geertz, o elemento dramatizado cotidianamente em rituais é construído a partir do ethos de uma sociedade, aquilo que expressa sua visão de mundo. Para ele o "ethos” seria: “... o tom, o caráter, a qualidade da sua vida, seu estilo e disposições morais e estáticas - e sua visão de mundo - o quadro que fazem do que são as coisas na sua simples atualidade, suas ideias mais abrangentes sobre ordem”. GEERTZ, Clifford. A interpretação das culturas. Rio de Janeiro: Guanabara Koogan, 1989. p. 104.

${ }^{16}$ DAMATTA. Roberto . Op. cit., p. 16.

${ }^{17}$ SEBRELI, Juan José. La era del fútbol. $1^{\text {a }}$ ed. Buenos Aires: Debolsillo, 2005. p. 17.

${ }^{18}$ Idem. Ibidem. p. 27.
} 
com Sebreli, a finalidade do futebol seria enquadrar o ímpeto juvenil em favor dos interesses nacionalistas e das classes dominantes ${ }^{19}$.

Além de refutar o determinismo social presente na teoria de Sebreli, as características próprias do jogo formuladas por Huizinga e expostas acima ressaltam a liberdade como um dos elementos básicos do jogo. Desse modo, existe sempre a possibilidade criadora em sua prática, ou seja, ele não é apenas um reflexo social, mas elemento cultural que estabelece uma relação dialética com a sociedade.

Do mesmo modo, a concepção do jogo de futebol como rito social contraria o conceito do torcedor de futebol como um indivíduo alienado que sem identidade própria se apropria da identidade do clube futebolísitco ${ }^{20}$. O torcedor é um oficiante do ritual futebolístico, cuja crença no clube o faz vivenciar o jogo em toda a sua complexidade.

Assim, teorias como a formulada por Sebreli, para o qual o futebol constitui o ópio do povo ${ }^{21}$, é elemento utilizado somente para demarcar os interesses dos diferentes regimes políticos, para compensar simbolicamente as dificuldades cotidianas vivenciadas pelos setores pobres da sociedade, adestrar a massa, afastá-la da reflexão de seus reais problemas e controlá-la psicologicamente, não se mantêm quando percebe-se o jogo de futebol como um ritual público realizado cotidianamente na sociedade, em diferentes esferas, seja nas cerimônias políticas, partidas, linguagem, imprensa escrita, transmissões de rádio, etc.

Conforme escreveu Nelson Rodrigues, ao ser analisado o futebol deve ser considerado como drama social, vislumbrando-se suas tragédias e paixões, ou seja, é

\footnotetext{
${ }^{19}$ Idem. Ibidem. p. 23.

${ }^{20}$ Idem. Ibidem. p. 40.

${ }^{21}$ Idem. Ibidem. p. 155.
} 
preciso atentar-se para a sociedade em que ele se encontra, para os seus diferentes participantes, discursos, utilizações políticas e econômicas. Na epígrafe da dissertação encontra-se a inspiração e o caminho que guiou toda a pesquisa de mestrado.

A fim de identificar como os jogos de conflitos e interesses presentes na política e, dialeticamente, no futebol foram processados pelos estados de São Paulo e do Rio de Janeiro durante o Estado Novo, foram investigados como alguns de seus periódicos (veículos de informações das classes dominantes) tratavam seus times e selecionados locais de futebol.

Além disso, houve a análise da própria composição do selecionado brasileiro para apreender a concepção de futebol presente na imprensa e como esse órgão auxiliou o governo no controle das massas por meio desse esporte.

Para contextualizar o período pesquisado, introduz-se a dissertação com a demarcação do estadonovista, caracterizando seus eixos norteadores e a preocupação de proporcionar espetáculos públicos afins com esses princípios, voltados para controlar grandes multidões.

Visando a melhor compreender como esse controle social se realizava, o primeiro capítulo apresenta as bases constitutivas do Estado Novo, como a censura e a publicidade realizada pelo governo no período. Além disso, analisou-se como a paixão das classes populares por um esporte inicialmente elitista, no embrionário contexto da cultura de massa, foi utilizada pelo Estado para difundir seus ideais na sociedade.

A padronização social realizada pelo governo com o auxílio da imprensa 
constituiu tema do segundo capítulo. A burocratização do jogo de futebol como reflexo da coerção social e a finalidade política da construção do Pacaembu foram assuntos igualmente contemplados nesse capítulo.

Como exceção desse controle social e futebolístico, a figura do maior futebolista da época, Leônidas da Silva, foi analisada como um símbolo catalisador de sentimentos populares que, por esse motivo, foi amplamente utilizado pela propaganda estadonovista.

A imprensa do período foi analisada no terceiro capítulo como elemento fundamental para construir a nação nos moldes pensados pelo governo getulista, pois, através desse meio de comunicação o futebol era propagandeado como espetáculo de massa em sintonia com os ideais estadonovistas, censurando os elementos considerados nocivos à harmonia social e destruindo qualquer esboço de contestação popular.

No quarto capítulo, a Copa do Mundo de Futebol de 1938 foi destacada para a análise de como os grandes eventos futebolísticos e as imagens dos jogadores foram cuidadosamente trabalhadas a fim de demonstrar para o grande público as noções de harmonia e patriotismo caros à construção nacional engendrada pelo Estado.

Como contraponto dessa manipulação do governo varguista, através do futebol, destacou-se como esse esporte ajudou a concretizar e divulgar as fissuras presentes na ideologia do regime. Desse modo, também foram analisadas no mesmo capítulo as notícias sobre rebeldia de jogadores, prática de futebol feminino e outras notas representativas de conflitos regionais entre os estados de São Paulo e do Rio de Janeiro.

Para ser ter uma visão de como a elite paulistana utilizou o futebol estadual para demarcar a sua suposta superioridade frente aos demais estados da federação, o capítulo quatro também contém informaçãos sobre o mito da excepcionalidade bandeirante, presente tanto no âmbito político, como no futebolístico. 
Algumas considerações sobre a origem do São Paulo Futebol Clube foram realizadas a fim de sugerir a sua criação e construção identitária como início da retomada de poder da elite paulista nos rumos políticos nacionais e a afirmação do futebol estadual perante aquele praticado pelos demais estados.

Finalizando o texto foram feitos breves comentários ressaltando o futebol como ritual misto dessa socidade e elemento propício para a análise histórica, foi também demarcado o período estadonovista como um regime autoritário calcado na propaganda política, retomou-se a noção de burocratização social centralizada na ideologia trabalhista e na paixão futebolística e foram destacadas a disputa entre os diferentes grupos elitistas para continuar a reger os rumos político-econômicos do país. 


\section{INTRODUÇÃO}

No final do século XIX, a acumulação de capital proporcionada pela economia agro-exportadora permitiu o surgimento de algumas indústrias espalhadas em diferentes regiões do país. Com a aplicação diversificada do capital proveniente do cultivo e exportação do café, constituiu-se uma sociedade urbana de massa baseada no capital industrial $^{22}$.

Assim, durante a crise de 1929, enquanto os grandes cafeicultores amargaram a diminuição no preço de exportação do café, os setores urbanos e industriais se voltaram para o mercado interno e prosperaram economicamente.

Sob esse contexto de caos econômico e reorganização social, ocorreu a tomada de poder realizada pelas elites dissidentes, em 1930, obrigando as oligarquias cafeeiras disputarem um espaço com os novos grupos urbanos socialmente emergentes para se manter na esfera decisória dos rumos políticos do país. Sobre essa reacomodação política, Eli Diniz escreveu: “Trata-se de uma hegemonia [do Estado] que se legitima por ser um meio de resguardar as
posições econômicas dos grupos tradicionais, favorecendo ao mesmo tempo, a massa dos
setores emergentes, particularmente a burguesia industrial” ${ }^{23}$.

O futebol nesse turbulento período foi reconhecido pelos novos governantes como um poderoso elemento mobilizador das massas e a seleção brasileira como um símbolo catalisador da nacionalidade ${ }^{24}$. Assim, em 1931, a atividade futebolística foi

\footnotetext{
${ }^{22}$ DINIZ FILHO, Luis Lopes. Território e destino nacional: Ideologias geográficas e políticas territoriais no Estado Novo (1937-1945). Dissertação de Mestrado - FFLCH/ USP. São Paulo, 1993. p. 6.

${ }^{23}$ DINIZ, Eli. “O Estado Novo: Estrutura de poder, relações de classes”. IN: FAUTO, Boris (Org.). História Geral da civilização Brasileira. T. III, v. 3. Cap. II. O Brasil Republicano. Sociedade e Política (1930-1964). São Paulo: Difel, 1981. p. 84.

${ }^{24}$ FRANCO JUNIOR, Hilário. A dança dos deuses: Futebol, cultura e sociedade. São Paulo: Companhia das Letras, 2007. p. 78.
} 
profissionalizada de acordo com a legislação trabalhista, legitimando a ideia de o jogador de futebol trabalhar em prol da nação.

Nesse sentido, sempre que era interessante ao governo ter a sua imagem associada com o futebol nacional, os eventos ligando políticos e futebolistas eram organizados e divulgados para a população. O primeiro contato entre o governo presidido por Vargas e o futebol foi realizado em dezembro de 1932 quando a seleção brasileira que atuou na Copa Rio Branco, disputada no Uruguai, voltou ao país desfilando em carro aberto até chegar ao Catete, onde recebeu um asceno do presisente $^{25}$.

Desde o seu início, o governo varguista percebeu que o futebol detinha o poder de moldar a visão que o brasileiro fazia de si próprio. Em 1933, um ano após a revolta em São Paulo, na tentativa de minimizar os conflitos decorrentes da rivalidade política entre os estados de São Paulo e do Rio de Janeiro, criou-se a Taça Rio-São Paulo para tentar uma maior aproximação entre esses dois estados ${ }^{26}$.

Em 1934, foi promulgada a mais avançada carta constitucional já escrita no país. Ela regulamentou o voto secreto e feminino, o salário mínimo e outros direitos trabalhistas. Com o apoio obtido junto à população urbana, o novo arranjo político liderado por Vargas enquadrava as oligarquias e reduzia a autonomia regional em nome da unidade nacional ${ }^{27}$.

Ao mesmo tempo em que se incluíam as camadas subalternas urbanas no jogo político nacional, um maior número de torcedores foram incoporados ao universo do futebol. Essa ampliação no número de torcedores ocorreu, especialmente, graças a dois

\footnotetext{
25 AGOSTINO, Gilberto. Vencer ou morrer. Futebol, geopolítica e identidade nacional. Rio de Janeiro: Faperj/ Mauad, 2002. p. 142.

${ }^{26}$ AGOSTINO, Gilberto. loc cit.

${ }^{27}$ FRANCO JUNIOR, Hilário. Op. cit., p. 79.
} 
processos, a saber: a concretização do profissionalismo nos dois maiores estados do país, São Paulo e Rio de Janeiro, e a maciça cobertura realizada pelos jornais e rádios nos eventos futebolísticos ${ }^{28}$.

Essa propriedade gregária do futebol foi analisada por José Miguel Wisnik. Para o autor, o futebol provoca uma "hipnose compartilhada" no torcedor, identificando-o com outros indivíduos detentores de ideais iguais aos seus, como a adoração de determinados ídolos e clubes. Como ritual cotidiano e popular, o futebol constitui-se representante das paixões e desejos de grupos sociais, capaz de mobilizá-los à construção da sociedade na qual estão inseridos ${ }^{29}$.

Com receio de perderem os seus lugares privelegiados na política nacional, as velhas oligarquias e a nova elite industrial apoiaram a instauração do Estado Novo, em 1937. Apesar da aparente contradição existente entre os ideais estadonovistas e os pertencentes a esses grupos sociais, pois o primeiro era centralizador, anti-regionalista e autoritário, enquanto a nova elite e as oligarquias regionais eram federalistas e liberais, não havia conflito entre essas duas esferas de poder. O Estado colocava-se acima dos interesses de classes, enquanto os setores dominantes governavam de fato ${ }^{30}$.

A consolidação do regime autoritário era realizada por meio da intensa divulgação de uma ideologia oficial baseada em princípios elitistas, conservadores, nacionais e autoritários. O elitismo contribuiria para desacreditar a sabedoria popular e as teorias de um governo pela maioria. O conservadorismo não era uma defesa intransigente do status quo, mas uma concepção de mundo onde a ordem, a hierarquia e a tradição tinham papel preponderante. O nacionalismo e o autoritarismo completariam

\footnotetext{
${ }^{28}$ Idem. Ibidem. p. 78-79.

${ }^{29}$ WISNIK, José Miguel. Veneno remédio. O futebol e o Brasil. São Paulo: Companhia das Letras, 2008. p. 52.

${ }^{30}$ CARONE, Edgar. O Estado Novo (1937-1945). São Paulo: Difel, 1977. p. 113.
} 
o papel de formação do Estado Nacional, com base nos ideais de justiça, “democracia social” e "razão de Estado” 31 .

Para Mônica Velloso, em nenhum período anterior ao Estado Novo houve tanto empenho para legitimar o governo e se recorreu a aparatos ideológicos tão sofisticados. A ideologia estadonovista foi colocada como elemento central no plano político, pois lhe conferia legitimidade, organizava-o e integrava os diferentes atores sociais ${ }^{32}$.

A mitificação da nação e dos seus expoentes e chefes igualmente fazia parte da ideologia estadonovista. Na constituição dessa mitologia nacional, na qual mito e comemoração eram conjugados, com o primeiro acentuando as qualidades do governo, e o segundo tornando-as públicas, Carone destacou três elementos: a presença da massa popular, a confusão existente entre os valores das classes dirigentes e as ações do Estado como forma de propaganda e pressão ${ }^{33}$.

Essas características da mitologia estadonovista seriam a tríade base do movimento iniciado a partir de 1930 denominado, posteriormente, como populismo. Os primeiros estudos sobre o tema formulados por intelectuais preocupados com a crise nacional em curso na década de 50, do século XX, construíram por meio da combinação dos elementos citados acima, o modelo clássico para se compreender manifestações populistas, conforme salientou Ângela de Castro Gomes:

\footnotetext{
"O que importa aqui destacar é a seleção de variáveis histórico-sociológicas efetuada para a construção do modelo, bem como o perfil dos atores que o integram: um proletariado sem consciência de classe; uma base dirigente em crise de hegemonia; e um líder carismático, cujo apelo subordina instituições (como o partido, embora com ele conviva) e transcende fronteiras sociais (de classe e entre os meios urbano/ rural)" ${ }^{34}$.
}

\footnotetext{
${ }^{31}$ OLIVEIRA, Lúcia Lippi, VELLOSO, Mônica Pimenta e GOMES, Ângela Maria Castro. Estado Novo. Ideologia e Poder. Rio de Janeiro: Zahar Editores, 1982. p. 15.

${ }^{32}$ Idem. Ibidem. p. 72.

${ }^{33}$ CARONE, Edgar. Op. cit., p. 166.

${ }^{34}$ GOMES, Ângela de Castro. O populismo e as ciências sociais: notas sobre a trajetória de um conceito. IN: FERREIRA, Jorge (Org). O populismo e sua história: debate e crítica. Rio de Janeiro: Civilização Brasileira, 2001. p. 25-26.
} 
Pela análise dos estudos sobre populismo, sejam eles tradicionais ou atuais, percebe-se a dificuldade em integrar o aspecto geral e o caráter particular do fenômemo. Desse modo, o populismo foi pensado como uma categoria analítica para vislumbrar determinados fenômenos em diferentes sociedades e épocas ou como um fenômeno histórico, com data e local específico ${ }^{35}$. A historiadora Maria Helena Capelato, em sua análise sobre o populismo argentino e mexicano, apontou da seguinte maneira os problemas de compreender o populismo nesses parâmetros:

"Um dos perigos desta última tendência é atomizar os processos históricos, tornando-os fragmentados e contingentes, impedindo a captação de seu sentido e direção mais amplos; o perigo da primeira é a possibilidade de distorcer a informação empírica para forçá-la a encaixar-se nas suas categorias de sua análise conceitual”36.

Partidário da noção de populismo como categoria histórica para explicar determinado período, Jorge Ferreira afirmou, em um dos textos que compõe o livro organizado por ele próprio e portador de novas considerações sobre o tema, que o populismo brasileiro não se inciou em 1930 e teve sua crise em 1964, mas foi criado posteriormente para explicar essa fase política de nossa história:

\begin{abstract}
"Nas páginas que se seguem, procuro reconstituir a história do populismo. No entanto, é importante frisar, não compreendo a expressão como um fenômeno que tenha regido as relações entre Estado e sociedade durante o período de 1930 a 1964 ou como uma categoria peculiar da política brasileira naquela temporalidade, pois sequer creio que o período tenha sido 'populista', mas sim, como uma categoria que, ao longo do tempo, foi imaginada e, portanto, construída para explicar essa mesma política” ${ }^{37}$.
\end{abstract}

Concordando com Jorge Ferreira, retomou-se no prsente texto o conceito de

\footnotetext{
${ }^{35}$ CAPELATO, Maria Helena Rolim. Populismo latino americano em discussão. IN: FERREIRA, Jorge (Org). Op. cit., p. 139.

${ }^{36}$ loc cit.

${ }^{37}$ FERREIRA, Jorge. O nome e a coisa: O populismo na política brasileira. IN: FERREIRA, Jorge (Org). Op. cit., p. 63-64.
} 
populismo para auxiliar na compreensão das características autoritárias e de manipulação do governo estadonovista mas, concomitantemente, buscou-se destacar as características específicas desse fenômeno presentes naquele momento histórico.

De acordo com Francisco Weffort, o populismo estadonovista iniciou-se em 1930, quando a crise do liberalismo oligárquico brasileiro e a necessidade institucional das bases sociais de poder do Estado articularam variadas alianças políticas, aproximando os setores industriais das classes médias urbanas e das classes populares $^{38}$.

O incremento no desenvolvimento do capitalismo industrial, de acordo com Weffort, procovou o êxodo rural e trouxe uma mão-de-obra com tradições patrimoniais, individualista e sem tradição sindical para as cidades ${ }^{39}$. Essa massa desorganizada e passiva seria incorporda ao processo político via submissão às formulações populistas ${ }^{40}$.

Para esse autor, algumas das características principais do populismo como expressão política de uma deteminada classe seriam a presença da massa formada por proletários que se ligariam por uma sociabilidade periférica e mecânica, a transformação da classe dirigente como aquela que deveria dominar e dar exemplo às demais e a existência de um líder carismático ${ }^{41}$. Nesses termos, o populismo consistia na representação política da massa a despeito de suas próprias vontades:

“... o populismo, nestas formas espontâneas, é sempre uma forma popular de exaltação de uma pessoa na qual esta aparece como a imagem desejada para o Estado (...) A massa se

\footnotetext{
${ }^{38}$ GOMES, Ângela de Castro. O populismo e as ciências sociais: notas sobre a trajetória de um conceito. IN: FERREIRA, Jorge (Org). Op. cit., p. 32.

${ }^{39}$ FERREIRA, Jorge. O nome e a coisa: O populismo na política brasileira. IN: FERREIRA, Jorge (Org). Op. cit., p. 75.

${ }^{40}$ WEFFORT, Francisco Correa. O populismo na política brasileira. Rio de Janeiro: Paz e Terra, 1980. p. 17.

${ }^{41}$ Idem. Ibidem. p. 26.
} 
volta para o Estado e espera dele 'o solou a chuva', ou seja, entrega-se de mãos atadas aos interesses dominantes" ${ }^{42}$.

Em regimes ditatoriais, o populismo se reforça juntamente com a soberania do Estado em relação aos demais setores sociais, pois a legitimação do regime através das massas ocorre mais facilmente por meio das suas doações, decisões arbitrárias e manipulações às massas e outros grupos econômicos:

\begin{abstract}
"Firmando seu prestígio nas massas urbanas, Getúlio estabelece o poder do Estado como instituição e este começa a ser uma categoria decisiva na sociedade brasileira. Relativamente independente desta, através dos mecanismos de manipulação, passa a impor-se como instituição inclusive aos outros grupos economicamente dominantes.

O Estado não deixa, porém, de ser solução de compromisso e de equilíbrio entre aqueles grupos. Contudo, como pode se legitimar através das massas, encontra naquele compromisso uma forma de poder; passa à condição de árbitro que decide em nome dos interesses nacionais" ${ }^{43}$.
\end{abstract}

Por ter em sua base a massa popular urbana como novo personagem social, o populismo, representado idealmente através da imagem de um líder carismático, auxiliou o Estado Novo a construir a imagem de uma nação unida e harmônica, em sintonia aos supostos interesses do "povo brasileiro", mascarando os conflitos existentes entre os diferentes setores sociais.

Na esteira do projeto de unidade nacional, um dos alvos constantemente atacados pela ideologia estadonovista pela propaganda foi a herança regionalista da República Velha, cujo exemplo radical foi a revolta de São Paulo ${ }^{44}$, em 1932, conforme especificado no capítulo V.

No discurso inaugural do regime de 1937, Getúlio Vargas apontou o separatismo e o imperialismo como fatores de desagregação nacional externa e interna

\footnotetext{
${ }^{42}$ Idem. Ibidem. p. 36.

${ }^{43}$ Idem. Ibidem. p. 103.

${ }^{44}$ SKIDMORE, Thomas E. Brasil: de Getúlio Vargas a Castelo Branco (1930-1964). Rio de Janeiro: Paz e Terra, 1975. p. 59.
} 
no país. Nesse contexto, duas cerimônias podem exemplificar a preocupação em fazer vingar o projeto de unidade nacional, de construir o próprio Estado Nacional.

Na primeira dessas cerimônias, Vargas e alguns chefes estaduais colocaram-se em frente de uma urna prata proferindo discursos em prol da unidade nacional, enquanto representantes de todos os estados da federação nela depositavam, um após o outro, punhados de terra das suas respectivas regiões ${ }^{45}$.

A outra cerimônia, conhecida como “cerimônia das bandeiras”, realizada na Esplanada do Russell, no Rio de Janeiro, nove dias após a promulgação do Estado Novo, objetivava propagar o artigo segundo da Constituição que legalizava a exclusividade do uso de símbolos, hinos e bandeiras nacionais em cerimônias.

O simbolismo dessa cerimônia não deixa dúvidas quanto à intenção do regime em proclamar a submissão do poder estadual à União. Enquanto o maestro Heitor Villa Lobos regia um conjunto de várias bandas e um coro de colegiais na execução do Hino Nacional, as vinte e uma bandeiras estaduais foram queimadas em uma grande pira colocada no centro da praça e, logo depois, vinte e uma bandeiras nacionais foram hasteadas em substituição àquelas ${ }^{46}$.

A inauguração do estádio do Botafogo igualmente foi marcada pela preocupação do governo em dissipar a herança regionalista e firmar a unidade nacional, conforme noticiou a Gazeta de Notícias em sua seção esportiva:

"Sobre o gramado, no centro do campo de foot-ball, será estendido um grande mappa do Brasil, com os seus Estados, o Districto Federal e o território do Acre, devidamente

\footnotetext{
${ }^{45}$ DINIZ FILHO, Luis Lopes. Op. cit., p. 57.

${ }^{46}$ Idem. Ibidem. p. 58.
} 
delimitados. Uma enorme bandeira do Brasil abrir-se-á em frente à tribuna social. O coro orpheonico do Collegio Salesiano Santa Rosa, de Nitheroy, composto de vinte e dois meninos, symbolizando as unidades da Federação, entoará o Hynno à Bandeira, enquanto personalidades illustres collocarão sobre o mappa, na área de cada qual, as terras dos seus respectivos Estados. Findo este acto, o presidente Getúlio Vargas procederá unificação solenne das terras, ao som do Hynno Nacional (...) Este acto symbolico de unidade pátria será saudado com uma salva de vinte e um tiros" ${ }^{47}$.

A cerimônia presidida no estádio Botafogo tem um simbolismo muito forte, pois a união dos estados da federação em uma só nação estaria abençoada ao ocorrer na inauguração de um santuário da bola. A salva de tiros e a presença do chefe nacional como elementos representativos da ordem e do aparelho burocrático do Estado legitimariam a união nacional.

Completando o ritual de inauguração, o clássico futebolistico entre o time da casa e o Fluminense, naquele momento detentor do título de campeão carioca, tinha a função de trazer a massa torcedora para a aula de civismo e patriotismo.

Essa preocupação em efetivar o projeto de unidade nacional legitimava-se na crença de que a democracia e a segurança nacional só se concretizariam sob um regime centralizado, sem intermediários entre o povo e o chefe da nação incipiente, ou seja, quando se concretizasse o Estado Nacional.

A necessidade de construir uma unidade nacional foi considerada na Constituição de 1937 quando a legislação processual, civil, penal e financeira foram elevadas à escala nacional.

Esse documento também definiu o território nacional como unidade econômica, comercial e alfandegária, cabendo à União a prerrogativa exclusiva de regular matéria pertinente. O seu dispositivo nono conferia ao poder central a

\footnotetext{
${ }^{47}$ Gazeta de Notícias, 28 de agosto de 1938, p. 14.
} 
prerrogativa de intervir, em determinadas situações, diretamente nos governos estaduais $^{48}$.

Para fazer essa unidade se concretizar o Estado Novo, por meios autoritários e propagandas, reforçava a necessidade de se realizar um caldeamento étnico, integrar territorialmente as diferentes regiões, centralizar o poder político no Estado sediado no Rio de Janeiro, fixar a autoridade estatal em todo país e implemantar uma comunhão cultural e religiosa no povo ${ }^{49}$.

Nesse contexto, a Comissão Nacional do Livro Didático, criada em 1938, proibiu a criação de livros didáticos inspiradores de sentimentos desagregadores da unidade nacional, como os de superioridade ou inferioridade do homem de uma determinada região do país, em detrimento das demais regiões. Além disso, tal Comissão proibiu a utilização excessiva de expressões regionais incitantes de conflitos entre as classes sociais ou provocadoras de ódio entre as diferentes raças ${ }^{50}$.

Porém, conforme escreveu Hobsbawn, as nações são fenômenos duais, pois ao mesmo tempo em que são construídas essencialmente pelo alto, englobam sentimentos, necessidades, aspirações e interesses de pessoas comuns, não necessariamente nacionais ou nacionalistas ${ }^{51}$.

Assim, não importaria a ideologia oficial propagandeada pelo Estado para construir a nação pois, apesar da sua existência, ela não excluiria ou seria superior ao

\footnotetext{
${ }^{48}$ DINIZ FILHO, Luis Lopes. Op. cit., p. 60.

49 CAPELATO, Maria Helena Rolim. Multidões em cena. Propaganda política no Varguismo e no Peronismo. Campinas: Papirus, 1998. p. 223.

${ }^{50}$ Idem. Ibidem. p. 220.

${ }^{51}$ HOBSBAWM, Eric J. Nações e nacionalismos desde 1780. Programa, mito e realidade. $5^{\circ}$ ed. São Paulo: Paz e Terra, 2008. p. 19.
} 
restante das identificações construtoras do ser social ${ }^{52}$. Inclusive, para o autor, a identificação nacional sempre se combina com outro tipo de identificação, mesmo quando pode ser sentida como superior às demais ${ }^{53}$.

No esforço em concretizar o Estado Nacional, o governo varguista associou a identificação política com a futebolística. Conforme visto acima, a prática futebolística proporciona experiências ritualísticas que conferem uma realidade palpável àquilo que, de outro modo, seria uma comunidade imaginada ${ }^{54}$.

Sobre a utilização do esporte para a afirmação nacional, Hobsbawn escreveu:

"Entre as guerras, porém, o esporte internacional tornou-se, como George Orwell logo notou, uma expressão de luta nacional, com os esportistas representando seus Estados ou nações, expressões fundamentais de suas comunidades imaginadas (...) O que fez do esporte um meio único, em eficácia, para inculcar sentimentos nacionalistas, de todo modo só para homens, foi a facilidade com que até mesmo os menores indivíduos políticos ou públicos podiam se identificar com a nação, simbolizada por jovens que se destacam no que praticamente todo homem quer, ou uma vez na vida terá querido: ser bom naquilo que faz. A comunidade imaginária de milhões de pessoas parece mais real na forma de um time de onze pessoas com nome. O indivíduo, mesmo aquele que apenas torce, torna-se o próprio símbolo da sua nação" 55 .

Desse modo, apesar de a maioria dos jogadores que disputaram o Campeonato

Mundial de 1938 realizado na França serem cariocas, a seleção foi celebrada pelos governantes como expressão da unidade nacional ${ }^{56}$.

Utilizando o futebol para garantir o apoio da massa ao governo estadonovista e

\footnotetext{
${ }^{52}$ Uma outra forma de identidade social é aquela forjada pelo futebol. Cf. ANTUNES, Fátima Martin Rodrigues Ferreira. Com brasileiro não há quem possa. Crônicas de futebol e identidade nacional. Tese de Doutorado - FFLCH/ USP. São Paulo, 1999; DAMATTA. Roberto (Org). Op. cit., Cap. 1 e 4; FRANCO JUNIOR, Hilário. Op. cit., p. 213-215 e TOLEDO, Luíz Henrique de. Torcidas Organizadas de Futebol. Col. Educação Física e Esportes. Campinas: Autores Associados/ Anpocs, 1996.

${ }^{53}$ HOBSBAWM, Eric J. Op. cit., p. 20.

${ }^{54}$ Idem. Ibidem. p. 86. Nessa parte do texto, Hobsbawn fez referências ao conceito de "comunidades imaginadas", pensado por Benedict Anderson. Para Anderson, todas as comunidades são construídas imageticamente e criam uma identidade artificial em seu interior, pois jamais todos os seus membros, por mais minúsculas que sejam, irão se conhecer plenamente. ANDERSON, Benedict. Comunidades imaginadas: reflexões sobre a origem e a difusão do nacionalismo. São Paulo: Companhia das Letras, 2008. p. 32.

${ }^{55}$ Idem. Ibidem. p. 171.

${ }^{56}$ FRANCO JUNIOR, Hilário. Op. cit., p. 81.
} 
divulgar seus ideais nacionais, a delegação brasileira convocada para disputar o Mundial de Paris foi recebida no Catete pelo presidente Vargas, antes de partir rumo à Europa ${ }^{57}$.

Além disso, durante esse campeonato, o Departamento de Imprensa e Propaganda (DIP) vinculou a figura de Getúlio Vargas ao futebol nacional como forma de criar uma aura simpática ao governo, valorizando as vitórias futebolísticas como se fossem vitórias da própria nação. Nesse contexto, a filha do presidente, Alzira Vargas, foi a madrinha do selecionado brasileiro durante o mundial de 1938, enviando diversos telegramas motivadores ao time.

Seguindo o mesmo propósito, os maiores estádios de futebol do país, São Januário e Pacaembu, eram os locais escolhidos para realizar as cerimônias cívicas, como as comemorações do Dia do Trabalho. Nesses eventos, era difundida a ideologia trabalhista de conciliação das classes e de valorização da ordem, disciplina e nacionalismo ${ }^{58}$.

Os estádios de futebol são, no ritual futebolístico, locais apropriados para a sua realização, pois neles os fiéis cultuam seus deuses, celebram seus heróis e exorcizam seus inimigos ${ }^{59}$. Suas formas arredondadas, localizações no território urbano, as distribuições dos espaços formadores do campo como as divisões dos assentos e os símbolos em seu interior, confirmam a ideia de futebol como metáfora religiosa ${ }^{60}$.

Assim esses locais, além de acomodarem grande quantidade de pessoas,

\footnotetext{
${ }^{57}$ AGOSTINO, Gilberto. Op. cit., p. 144.

${ }^{58}$ FRANCO JUNIOR, Hilário. Op. cit., p. 80.

59 De acordo com Durkheim, a função dos templos e santuários consiste em separar a vida profana para a vida religiosa. A vida religiosa somente pode se desenvolver em um espaço especial, onde as coisas e os seres sagrados podem ser apropriar com exclusividade. Para o sociólogo, a mesma exclusividade para o desenvolvimento do religioso deve ocorrer com o tempo, ou seja, devem existir períodos temporais específicos para o sagrado (como as festas). DURKHEIM, Emile. As formas elementares da vida religiosa. Os sistemas totêmicos na Austrália. São Paulo: Martins Fontes, 1996. pp. 326-327.
}

${ }^{60}$ FRANCO JUNIOR, Hilário. Op. cit., p. 271. 
proporcionavam aos espectadores uma noção de pertencimento, adoração à sua divindade, seja ela o clube de futebol ou a pátria, o ídolo futebolístico ou os heróis ligados ao governo.

Acompanhando o processo de burocratização administrativa presente no Estado Novo, foi criado o Conselho Nacional de Desportos, em 1941. Sobre o seu papel social, Hilário Franco Junior escreveu:

“[O CND era] vinculado ao Ministério da Educação e Cultura, que subordinava a CBD [Confederação Brasileira de Desportos] e federações regionais e tinha poder de fiscalização, normatização e organização de todas as modalidades esportivas do país. Seus objetivos eram a modernização esportiva e sua utilização para a legitimidade do regime. Ou melhor, a modernização esportiva para aquilo que parecia a modernização do Estado e da sociedade” ${ }^{2}$.

Em sua dissertação de mestrado, Eduardo Manhães destacou o paradoxo existente na legislação esportiva concebida pelo Estado Novo. A ordem dominante pregava intervenção e controle, enquanto a ordem desportiva necessitava de autonomia; a primeira queria a oficialização das entidades e a segunda era partidária da iniciativa privada; o aparelhamento da ordem querida pelo governo era desfavorável ao poder estatutário almejado pelos desportes; a verticalização linear das funções pretendida pelo centro do poder inviabilizava o pluralismo querido pelos desportistas e a harmonia almejada pela primeira contrariava o conflito intrínseco existente na segunda ${ }^{62}$.

Nessa onda regularizadora e autoritária, o artigo 25 do Decreto-lei $n^{\circ} 3.199$ regulamentava que as confederações deveriam ser órgãos executores das decisões do Conselho Nacional de Desportes (CND) e prestar informações à secretaria de tal Conselho. Para o CND caberia o direito de expulsar profissionais ligados aos desportos

\footnotetext{
${ }^{61}$ Idem. Ibidem. p. 81.

${ }^{62}$ MANHÃES, Eduardo Dias. Políticas de Esportes no Brasil. Rio de Janeiro: Graal, 1986. p. 32.
} 
e interferir financeiramente nas associações desportivas ${ }^{63}$.

Nessa conjuntura, os artigos 18 e 24 obrigavam as entidades desportivas a ocuparem espaços de unidades geopolíticas, fazendo tanto as federações serem filiadas às confederações e às ligas, como suas diretorias existirem na órbita municipal - cada confederação poderia filiar uma única federação por desporto, tendo o artigo 16, parágrafo segundo, denominado o futebol como “desporto básico da CBD” ${ }^{64}$.

Se o futebol deveria ser, durante o Estado Novo, seu desporto básico, a alínea “a” do artigo terceiro do mesmo Decreto-lei n 3.199 elucidou o futebol como “esporte nacional” brasileiro, pois nele estava escrito como competência precípua do CND: “... tornar os desportos, cada vez mais (...) uma alta expressão da cultura e da energia nacionais” 65 .

Confirmando essa ideia de futebol como “esporte nacional”, há o artigo 47, do mesmo decreto, no qual as confederações eram obrigadas a ter sede na capital da República - como representantes da nação. O texto do artigo 48 igualmente estabeleceu relações entre futebol e esporte nacional:

\footnotetext{
“A entidade desportiva exerce uma função de caráter patriótico. É proibido a organização e o funcionamento de entidades desportivas de que resulte lucro para os que nela empreguem capitais sob qualquer forma” ${ }^{66}$.

O desporto no período estadonovista estava contido em um processo educativo
} do Estado para reforçar a educação cívica e o seu discurso de uma nação solidária e homogênea. Nesse contexto, o futebol era um dos "sustentáculos sociais", pois representava uma alta expressão de nacionalidade e da própria moral cívica, reforçando

\footnotetext{
${ }^{63}$ Idem. Ibidem. p. 36.

${ }^{64}$ Idem. Ibidem. pp. 49-51.

${ }^{65}$ Idem. Ibidem. p. 59.

${ }^{66}$ Idem. Ibidem. p. 70.
} 
a identidade entre Estado e nação ${ }^{67}$.

Apesar do empenho de Vargas em constituir uma política desportiva no Brasil, o esporte nacional não conseguiu consagrar-se internacionalmente durante o Estado Novo, pois com a Segunda Guerra Mundial grande parte dos jogos foram suspensos.

Com a declaração brasileira de guerra, em 1942, os clubes ligados às colônias italianas e alemãs, como o Palestra Itália e o Germânia de São Paulo, sofreram graves intervenções do CND, além de serem hostilizados pelas torcidas adversárias, que os consideravam como “inimigos da pátria” e “súditos do eixo”.

A política anti-imigrante se radicalizou e passou a contar com o apoio da imprensa, do Departamento Estadual de Ordem Política e Social do Estado de São Paulo (DEOPS) e da própria população. Em sua tese de doutorado, Alfredo Salun afirmou não serem raras as ocupações de grêmios esportivos com ligação estrangeira, como aquela realizada pela União Nacional dos Estudantes quando ocupou a sede do Germânia $^{68}$.

Os clubes ligados às colônias de imigrantes foram obrigados a alterar seus nomes e uniformes. Além disso, eles não podiam continuar mantendo dirigentes estrangeiros em seus domínios. As hostilidades nos campos de futebol e de batalha dos brasileiros na Segunda Guerra Mundial para defender o Estado revelam, entre outras coisas, o quanto tinha se difundido o sentimento nacionalista, divulgado pelo governo autoritário, em nossa sociedade ${ }^{69}$.

A vinculação da ideologia estadonovista com a prática futebolística do período endossava a ideia concebida por Gilberto Freyre na qual o futebol era "uma verdadeira

\footnotetext{
${ }^{67}$ Idem. Ibidem. p. 79.

${ }^{68}$ SALUN, Alfredo Oscar. Palestra Itália e Corinthians: Quinta coluna ou tudo buena gente? Tese de Doutorado - FFLCH/ USP. São Paulo, 2007. p. 117.

${ }^{69}$ FRANCO JUNIOR, Hilário. Op. cit., p. 85.
} 
instituição brasileira, [que] tornou possível a sublimação de vários daqueles elementos irracionais de nossa formação social e de cultura” ${ }^{70}$.

Assim, esse esporte foi amplamente utilizado pelo Estado Novo para concretizar o seu ideal de nação, pois ele mobilizava os setores populares da sociedade, frequentadores dos estádios, leitores dos jornais esportivos ou ouvintes de jogos, em um novo contexto social, o da embrionária cultura de massas ${ }^{71}$.

Analisar como o futebol foi utilizado pelo Estado Novo para a concretização do seu projeto de construção nacional constitui-se de uma tentativa de vislumbrar os diversos conflitos presentes em uma sociedade formada por diferentes classes sociais. O historiador ao estudar o tempo presente se volta para o passado a fim de perceber, com mais nitidez, como a mesma problemática encontrada na atualidade se processou para poder interpretá-la com maior clareza.

\footnotetext{
${ }^{70}$ RODRIGUES FILHO, Mario. O negro no futebol brasileiro. $4^{\mathrm{a}}$ edição. Rio de Janeiro: Mauad, 2003. p. 25.

${ }^{71}$ Para Adorno e Horkheimar, condições sociais específicas, como a figura de um líder ou a identificação com um símbolo faz os homens se unirem nessa abstração denominada "massa”. Por meio dela, os indivíduos se submetem, criam aversão a grupos estranhos e agregam-se em prol de uma união ilusória. HORKHEIMAR, Max e ADORNO, Theodor. Temas básicos da sociologia. São Paulo: Editora Cultrix, 1983. p. 85
} 


\title{
1 A DOMESTICAÇÃO DO CORPUS SOCIAL
}

\subsection{A Sociedade Orgânica}

Um ponto necessário para a legitimação do governo denominado como "novo" era a modernização do próprio Estado brasileiro. Para isso era necessária a criação de um aparelho legislativo e burocrático afim com os padrões autoritários e centralizadores do governo, além de realizar a unificação territorial, ideológica e das diferentes identidades dos domínios brasileiros. Para a realização dessa ambiciosa tarefa, formulou-se um projeto cujos principais objetivos foram resumidos da seguinte forma, por Helena M. B. Bomeny:

\begin{abstract}
“O grande projeto político a ser materializado no Estado Novo, iniciado com a Revolução de 1930, tinha como núcleo central a construção da nacionalidade e a valorização da brasilidade, o que vale dizer, a afirmação da identidade nacional brasileira (...) Estava em questão a identidade do trabalhador, a construção de um homem novo para um Estado que se pretendia novo, e incluía-se igualmente nesta pauta a delimitação do que seria aceito como nacional e, por contraste, o que seria considerado estrangeiro, estranho, ameaçador. Ambicioso e extenso, o projeto estado-novista deveria orientar todas as iniciativas do Estado dirigidas à sua própria construção e à construção da sociedade" ${ }^{72}$.
\end{abstract}

Para cumprir a ousada missão foram implantadas várias reformas técnicas e criadas inúmeras propagandas para incutir nos habitantes do país a noção de pertencimento, unidade e identidade nacional. Assim, todos os elementos ligados ao regionalismo, como as crenças populares, ideias separatistas e exaltação da diferença social e econonômica entre as diferentes regiões da federação foram severamente combatidos pelo Estado Novo.

A integração territorial do país era considerada como fundamental aos planos governamentais de unir ideologicamente e economicamente os habitantes do país, nos

${ }^{72}$ BOMENY, Helena M. B. "Três decretos e um ministério: a propósito da Educação no Estado Novo”. IN: IN: PANDOLFI, Dulce (Org.). Repensando o Estado Novo. Rio de Janeiro: Ed. Fundação Getulio Vargas, 1999. Versão online: www.cpdoc.fgv.br, p. 151. 
moldes da modernidade e industrialização. Assim, projetos como a "marcha para o Oeste” vislumbravam essa integração de diferentes aspirações e costumes em prol do bem coletivo almejado pelo Estado. Sobre a vinculação da política expansionista no interior do país e o emprego de mão-de-obra nacional para atuar nos novos territórios ocupados, Ângela de Castro Gomes escreveu:

\begin{abstract}
“Com o estabelecimento do Estado nacional, a matéria [Decreto Lei n ${ }^{0}$ 19.482, que obrigava o emprego de dois terços de trabalhadores nacionais, nas empresas] ganhara novo impulso, na medida em que se associava ao grande movimento de ocupação de nosso território, lançado pelo presidente Vargas. A política de "Marcha para o Oeste" visava à expansão brasileira dentro de suas fronteiras e recolocava o problema da mão-de-obra necessária à coordenada conquista do interior do país” ${ }^{73}$.
\end{abstract}

No contexto de guerra mundial, discursos afirmavam ser próprio do imperialismo brasileiro a expansão demográfica e territorial dentro de seus domínios. O sertão, o isolamento e os localismos representavam o regionalismo herdado do período anterior ao governo getulista, intencionalmente denominado como República Velha, e eram duramente repudiados pelo Estado Novo.

Nesse combate, inúmeras metáforas foram utilizadas pelo governo para estimular as ocupações dos vazios demográficos existentes na época conhecidos como “oeste”. A ocupação dessas áreas pouco habitadas era vital para os interesses estadonovistas de unificação territorial e ideológica do país, além de fazer parte da sua estratégia de segurança nacional ${ }^{74}$.

Como exemplo dessas metáforas, destaca-se a utilização do mito bandeirante paulista no qual a exploração e interiorização no território brasileiro realizado pelas

\footnotetext{
${ }^{73}$ GOMES, Ângela de Castro. "Ideologia e trabalho no Estado Novo”. IN: PANDOLFI, Dulce (Org.). Op. cit., pp. 68-69.

${ }^{74}$ Uma análise mais completa sobre a vinculação do projeto de segurança nacional estadonovista ao sistema educacional do período e a importância conferida pelo regime à militarização no processo de educação social do indíviduo encontra-se em: BOMENY, Helena M. B. Op. cit., IN: PANDOLFI, Dulce (Org.). Op. cit., pp. 142-144.
} 
bandeiras no passado foram relembradas como feitos heroicos em prol da nação. No discurso pronunciado por Vargas publicado na Gazeta de Notícias, em 1939, os paulistas foram colocados como os eleitos para realizar o povoamento dessas regiões, pois teriam eles a tradição bandeirante de desbravar o desconhecido:

“... Caminhamos para a unidade, marchamos para o centro, não pela força de preconceitos doutrinários, mas pelo fatalismo da nossa definição racial. Não temos mais problemas regionaes; todos são nacionaes e interessam ao Brasil inteiro (...) E, como não decahiu o espírito emprehendedor e a coragem é a mesma dos velhos, estou certo de que os modernos bandeirantes assumirão, sem tardar, o seu posto nesta cruzada da expansão nacional” 75 .

Associava-se, assim, o regionalismo e seus mandatários locais ao liberalismo político-econômico presente no governo anterior a Vargas. Para acabar com essas características, o regime de 10 de novembro fundamentou-se sob as bases do autoritarismo, centralização política e intervenção estatal na economia. Vale dizer que, assim como demarcou Maria Antonieta P Leopoldi, essa base estadonovista foi sendo construída aos poucos, desde 1930:

\begin{abstract}
“Ao reorientar o modelo econômico brasileiro, o governo Vargas favoreceu o crescimento do setor produtivo e de serviços nas áreas urbanas. Assim, indústria, bancos e seguros iriam crescer a partir de 1930 sob a proteção de um Estado intervencionista, regulador, nacionalista e desenvolvimentista” ${ }^{76}$.
\end{abstract}

Na concepção de sociedade moderna proposta pelo Estado Novo, estava vinculada a noção de eugenia e caldeamento étnico. Como a nação deveria ser formada por cidadãos brancos ou mulatos com “alma branca”, a imigração europeia foi fomentada no período. Em contra partida, negros e mestiços eram vinculados à pobreza

\footnotetext{
${ }^{75}$ Gazeta de Notícias. 30 de agosto de 1939, p. 16. Na ocasião em que foi proferida a entrevista, Vargas estava em São Paulo para iniciar a construção de uma ponte no Rio Tietê. Para melhor compreensão sobre a construção do mito bandeirante e sua utilização para demarcar uma identidade paulista ver: FERRETTI, Danilo José Zioni. A construção da paulistanidade. Identidade, historiografia e política em São Paulo (1856-1930). Tese de Doutorado - FFLCH/ USP. São Paulo, 2004. e RAIMUNDO, Silvia Lopes. A invenção do mito bandeirante. Tradição e pensamento regionalista na historiografia paulista nas décadas de 1920-1930. Dissertação de Mestrado - FFLCH/ USP. São Paulo, 2001.

76 LEOPOLDI, Maria Antonieta P. "Estratégia de ação empresarial em conjunturas de mudanças política”. IN: PANDOLFI, Dulce (Org.). Op. cit., p. 118.
} 
e, em decorrência, à categoria de classes perigosas ${ }^{77}$ :

\begin{abstract}
"Se o mito das três raças aparece sempre envolvido por um embranquecimento do mestiço, a importação de brancos é jogada como o golpe certeiro para se assegurar o predomínio dos brancos 'superiores' em relação às 'raças inferiores'.Contava-se também, seja lembrado, com a gradual destruição física desses últimos”78.
\end{abstract}

Nesse contexto, a ideia de democracia racial estimulada por Gilberto Freyre durante uma conferência em Lisboa em julho de 1937, confirmava a preocupação de conferir harmonia em um contexto onde admitir a presença de diferentes classes sociais era impensável no projeto de nação fabulado pelo governo varguista.

Para a transmissão dos ideais do regime, inúmeras festas eram organizadas como forma de ritualizar publicamente determinadas ideologias, trazendo emoção e dramaticidade às normas, regras e doutrinas. Assim, o espaço público era ocupado de modo regrado pelas massas domadas, realizando o controle social governamental sem desfazer o aspecto natural e harmônico tão caro ao projeto de nação estadonovista.

De acordo com Cláudia Schemes, as cerimônias realizadas nesse período autoritário reforçavam as noções estadonovistas de comunhão e igualdade entre todos os diferentes atores sociais:

“A festa seria um ritual necessário para legitimar uma determinada situação. É atráves da emoção, do movimento dos símbolos e dos gestos que se procurava unir a sociedade, provocando a sensação de felicidade geral” ${ }^{79}$.

Aspectos do cerimonial religioso encontavam-se imbricados na política

\footnotetext{
${ }^{77}$ O conceito de "classes perigosas" foi pensado por Chalhoub, em seu livro sobre a Revolta da Vacina, no Rio de Janeiro. No texto, o autor analisou como esse conceito foi se ajustando a população pobre, em sua maioria descendente de ex-escravos, e legitimou a sua retirada do centro da cidade e instalação nos morros (formando o que hoje conhecemos como favelas) para o Estado realizar a reforma no centro urbano carioca, baseada nos princípios de modernização e eugenia. CHALHOUB, Sidney. Cidade Febril - cortiços e epidemia na corte imperial. São Paulo: Companhia das Letras, 1996.

${ }^{78}$ LENHARO, Alcir. Sacralização da política. 2a ed. Campinas: Papirus, 1986. p. 129.

${ }^{79}$ SCHEMES, Claudia. As festas cívicas e esportivas no populismo. Um estudo comparado dos governos Vargas (1937-1945) e Perón (1946-1955). Dissertação de Mestrado - FFLCH/ USP. São Paulo, 1995. p. 51.
} 
estadonovista, caracterizando o que Alcir Lenharo denominou de liturgia política. Um dos principais elementos da sacralização política consiste no fato de cada cidadão ser convidado a dar a sua vida, verter o seu sangue para a salvação do corpo social representado em última instância na pátria quando necessário ${ }^{80}$.

Na cerimônia política projetada pelo Estado Novo, a ideologia do regime foi divulgada de maneira intensa pelas teatralizações públicas voltadas à multidão, onde ideias e conceitos eram convertidos em imagens e símbolos significantes à massa populacional $^{81}$.

Assim, vários mitos políticos foram engendrados, pois na realidade social estadonovista havia um fenômeno de não identificação. A sociedade não se reconhecia pelas normas existentes e, por isso, se apoiava em grupos ou indivíduos definidos como diferentes dos demais.

De acordo com o historiador Raoul Girardet, a mitologia política pode ser realizada de quatro diferentes formas: pela conspiração, idade de ouro, unidade e pelo salvador. Durante o Estado Novo, esses quatros mitos foram continuamente trabalhados pelo regime, de modo a sustentá-lo ideologicamente ${ }^{82}$.

O embrião do período estadonovista foi a divulgação de uma conspiração realizada pelos comunistas para assumir o poder político, denominada como Intentona Comunista. O segredo, a união e hierarquia interna do grupo conspirador foram os elementos destacados para ressaltar a possibilidade de o corpo social sofrer riscos, caso eles conseguissem vingar seus planos, sendo esses sempre demonstrados de maneira

\footnotetext{
${ }^{80}$ LENHARO, Alcir. Op. cit., p. 18.

${ }^{81}$ CAPELATO, Maria Helena Rolim. Op. cit., p. 36.

${ }^{82}$ GIRARDET, Raoul. Mitos e mitologias políticas. São Paulo: Companhia das Letras, 1987.
} 
diabólica e subterrânea ${ }^{83}$.

Com a deturpação de um passado relativamente próximo e enaltecendo o presente de modo exagerado, o Estado Novo caracterizou o seu tempo como um exemplo de virtude a ser seguida, a idade de ouro para a nação brasileira. Fez parte dessa construção mítica a caracterização da sociedade brasileira como uma comunidade fechada, autossuficiente, moderna, encerrada em seu interior de modo tranquilo e feliz, alheia aos problemas e receios pertencentes estritamente ao mundo exterior.

Um dos elementos de maior destaque nos planos do regime era a constituição da unidade nacional. A pátria virtual se projetou primeiramente pela propaganda realizada pelo governo, cujo teor consistia em exorcizar do território os fatores contrários à unificação ideológica e territorial do país.

No discurso pronunciado na noite do golpe instaurador do Estado Novo, irradiado para todo país do Palácio da Guanabara, Vargas destacou a construção de uma nação unida como sendo a principal preocupação do seu governo, combatento os regionalismos e partidarismos presentes na sociedade brasileira ${ }^{84}$.

Para realizar essa tarefa, uma reforma administrativa foi consolidada em 1941, possibilitando a supremacia do governo central frente aos poderes estaduais e, assim, a eliminação dos últimos resquícios da política regionalista proveniente da República Velha.

Nesse contexto, inteventores estaduais nomeados pelo presidente substituiram

\footnotetext{
${ }^{83}$ Como exemplo do enraizamento social da teoria conspiratória durante o Estado Novo, destacou-se a que se construiu dentro do campo futebolístico. Em 1942, após a declaração de guerra brasileira, o Palestra Itália sofreu hostilidades por parte das demais torcidas por ter a sua imagem associada à Itália, país pertencente ao Eixo. Desse momento, os palestrinos guardam uma história conspiratória que eles afirmam ser verdade: o São Paulo Futebol Clube, chefiado por Porfírio da Paz, tentou invadir o Palestra para tomar seu patrimônio, mas foi surpreendido pela vigília de Adalberto Mendes que não deixou o fato se concretizar. SALUN, Alfredo Oscar. Op. cit., Cap. 3.

${ }^{84}$ VARGAS, Getúlio. A nova política do Brasil. Livro V- O Estado Novo (10 de novembro de 1937 a 25 de julho de 1938). Rio de Janeiro: Livraria José Olympio Editora, 1938. p. 23.
} 
os governadores nas funções legislativa e judiciária e aplicavam medidas relativas ao estado de emergência no âmbito estadual. Esses inteventores eram supervisionados pelo Departamento Adminstrativo existente em cada estado, subordinado ao Ministério da Justiça, cujo diretor era nomeado por Vargas ${ }^{85}$.

A sacralização de figuras políticas comum em governos totalitários concretizou-se no Estado Novo com o culto ao presidente Getúlio Vargas. O presidente era visto como o pai dos pobres, a cabeça de uma socidade orgânica, ou seja, quem ordena para o corpo social obedecer. Sobre a influência da propaganda na construção do mito varguista, Alcir Lenharo escreveu:

"Era enorme o esforço desenvolvido pelas agências de propaganda e informação do regime no intuito de moldar a cabeça de Vargas de modo que ela fosse reveladora de facetas que escapassem da esfera do homem comum. O lado humano não era negligenciado: Vargas surge sempre sorridente, jovial, confiante. Entretanto, é mais constante nessa composição o casamento de perfis derivados da excepcionalidade de sua pessoa com os perfis de homem público, desdobrados ao político capaz e reformador social” ${ }^{86}$.

Na construção do herói Vargas podemos constatar as três temporalidades presentes na formação da figura do salvador, conceituadas por Girardet ${ }^{87}$. O “tempo de espera e do apelo” realizou a formação e difusão da imagem do salvador desejado. A impressão de realização completa do curso da História aconteceu graças ao "tempo da presença” e o “tempo da lembrança” e ainda faz a figura desse salvador se perpetuar na memória coletiva.

Analisando os diferentes tipos de heróis conceituados pelo historiador, encontramos um condizente à figura salvadora de Getúlio Vargas. O herói cincinnatus seria um velho homem, cujos esforços para a paz conquistada por muito trabalho, o faria

\footnotetext{
85 SOLA, Lourdes. “O golpe de 1937 e o Estado Novo”. IN: MOTA, Carlos Guilherme (Org.). Brasil em perspectiva. Coleção Corpo e Alma do Brasil. São Paulo: Difusão Européia do Livro, 1969. p. 269.

${ }^{86}$ LENHARO, Alcir. Op. cit., p. 193.

${ }^{87}$ GIRARDET, Raoul. Op. cit., p. 72.
} 
exercer altos cargos $^{88}$.

Após essa vida pública, ele se retira para viver modestamente, mas quando a

desgraça assola seu povo, ele se sente obrigado a voltar a comandar o Estado. Assim, sua virtude seria gravitas, ou seja, a firmeza da provação, a experiência, a prudência, o sangue frio, o comedimento e a moderação.

Em sua análise sobre a sacralização política presente no Estado Novo, Lenharo associou o mito varguista com a santíssima trindade do catolicismo, fato que reforçava o poder imagético dessa construção junto às massas:

“O discurso do poder penetra e caminha por dentro do conjunto de símbolos, imagens e personagens familiares ao imaginário cristão. Sem querer calcar imagens sobre imagens (o discurso do poder opera muito mais à vontade com o movimento ambíguo delas) é possível perceber uma projeção da pessoa de Getúlio a um plano de divinização, desdobrável em uma trindade de imagens que se interpenetram e se contêm em uma só: Getúlio ora compreende à imagem do Pai, que vela e protege pelos filhos, imagem que recebe seu acabamento principal na figura do grande legislar social; ora indentifica-se mais com a imagem do Filho, líder que intervém na estória, predestinadamente, o Messias que veio para mudar seu fluxo e afastar outros intermediários; ora corresponde à figura do Espírito a iluminar os caminhos dos seus subordinados para uma nova ordem, amparada por outras luzes. Até mesmo a grandeza futura da pátria parece assemelhar-se ao tempo da escatologia, em que a bem-aventurança é finalmente alcançada" 89 .

Nos jornais do período, as fotos de Vargas habitualmente mostravam a cabeça

do presidente e embaixo dessa, eram postas fotos da multidão, concretizando

imageticamente a ideia de nação orgânica:

“A nação, por exemplo, é associada a uma totalidade orgânica, à imagem do corpo uno, indivisível e harmonioso; o Estado também acompanha essa descrição; suas partes funcionam como órgãos de um corpo tecnicamente integrado; o território nacional, por sua vez, é apresentado como um corpo que cresce, expande, amadurece; as classes sociais mais parecem órgãos necessários uns aos outros para que funcionem homogeneamente, sem conflitos; o governante, por sua vez, é descrito como uma cabeça dirigente e, como tal, não se cogita em conflituação entre a cabeça e o resto do corpo, imagem da sociedade” ${ }^{90}$.

\footnotetext{
${ }^{88}$ Idem. Ibidem. p. 73.

${ }^{89}$ LENHARO, Alcir. Op. cit., pp. 194-195.

${ }^{90}$ Idem. Ibidem. pp. 16-17.
} 


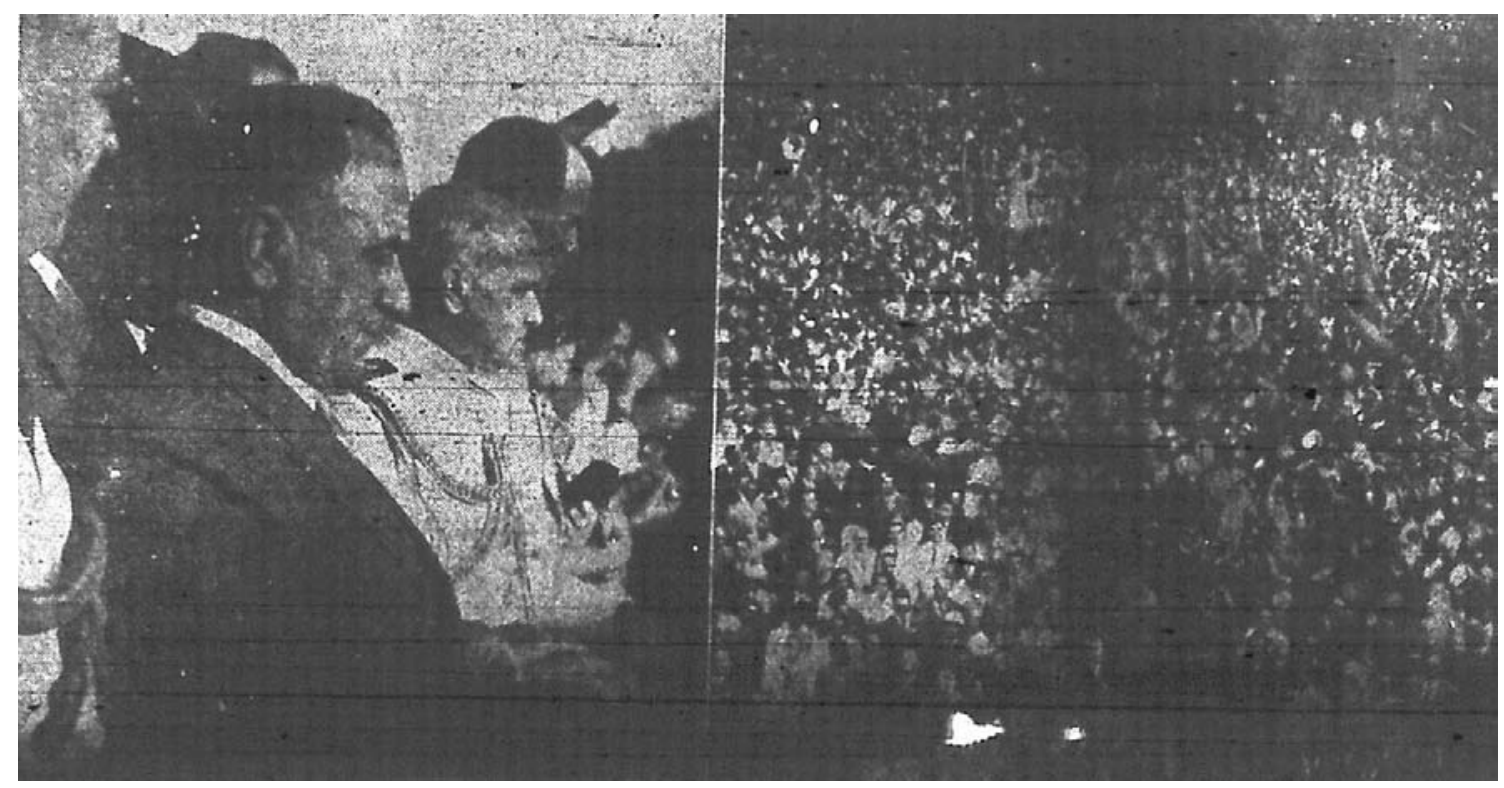

Nessa imagem, Vargas olha de modo paternal para o povo. Interresante notar a montagem da imagem em que as duas fotos, dispostas uma ao lado da outra, remetem a uma noção de superioridade de Vargas em relação ao povo, pois ele olha a massa de cima para baixo. Fotos publicadas no Correio Paulistano, 15 de maio de 1938, p. 1.

O povo era considerado pelo governo varguista uma massa ignorante, alienada e incapaz de se governar. Sendo assim, cabia ao Estado personificado na figura de seu presidente, tal como um bom pai, nortear esse ser infantil. Aprendendo a engatinhar, a incipiente nação não poderia correr o risco de ser manipulada pela esquerda, considerada como a terrível inimiga nacional.

Desse modo, uma atenção especial foi conferida às elites para realizar o projeto de unidade nacional, pois caberia a ela auxiliar o governo na construção do novo país e no controle da enorme massa de analfabetos constituinte do povo brasileiro, considerado inepto à participação política e ao papel de dirigente dos rumos nacionais.

De acordo com Vianna, os empresários sentiam-se como fiadores do "bem estar do conjunto social”, pois para essa classe social, era graças aos empregos concedidos por eles que os trabalhadores gastavam mais dinheiro, movimentando a 
economia nacional e proporcionando a modernização do setor agrícola ${ }^{91}$.

Nesse sentido, os trabalhadores deveriam cooperar harmoniosamente com as elites. Tais como os diferentes órgãos do organismo humano, as diversas classes sociais deveriam atuar solidariamente em prol do corpus social:

\begin{abstract}
"De volta aos anos 30, é preciso observar como um amplo jeito de reordenamento da sociedade - o corporativismo - se apóia interamente na imagem de organicidade do corpo humano. As partes que compõem a sociedade foram pensadas tal como o relacionamento do corpo humano: integradamente e sem contradição. O objetivo do projeto, portanto, visava a neutralizar os focos de conflitos sociais, tornando as classes (órgãos) solidárias umas com as outras” ${ }^{92}$.
\end{abstract}

Um importante instrumento do governo para escamotear o conflito presente entre as diferentes classes sociais foi a Lei de Segurança Nacional, promulgada em 1935. A propaganda política divulgava não existirem divergências entre os interesses classistas, e os discursos estadonovistas pediam a colaboração entre os diversos setores sociais para realizarem um trabalho comum em favor da cooperação e harmonia social.

Em seu livro sobre a formação sindical brasileira, Heloisa Martins reproduziu o discurso pronunciado por Vagas em São Paulo, em 23 de julho de 1938, no qual o presidente pediu colaboração entre as classes:

\begin{abstract}
“O Estado Novo não reconhece direitos de indivíduos contra a coletividade. Os indivíduos não têm direitos, têm deveres: Os direitos pertencem à coletividade! O Estado, sobrepondo-se à luta de interesses, garante os direitos da coletividade e faz cumprir os deveres para com ela. O Estado não quer, não reconhe luta de classes. As leis trabalhistas são leis de harmonia social” 93 .
\end{abstract}

A sindicalização do país foi regulamentada a fim de auxiliar a construção da pretensa paz social. Cada categoria profissional poderia ter apenas uma organização sindical para representá-la, sendo essa dirigida por um representante escolhido pelo Ministério do Tabalho. Assim, enfraqueceu-se a capacidade mobilizadora dos sindicatos

\footnotetext{
${ }^{91}$ VIANNA, Luis Werneck. Liberalismo e sindicato no Brasil. $2^{\mathrm{a}}$ ed. Rio de Janeiro: Paz e terra, 1978. p. 209.

${ }^{92}$ LENHARO, Alcir. Op. cit., p. 18.

93 MARTINS, Heloisa Helena Teixeira de Souza. O Estado e a burocratização do sindicato no Brasil. $2^{\mathrm{a}}$ ed. São Paulo: Editora Hucitec, 1989. p. 61.
} 
e, em decorrência, houve o esvaziamento desses.

As novas obrigações sindicais, como a construção de escolas e hospitais fez diminuir a base orçamentária dos sindicatos e o número de profissionais sindicalizados, minimizando a luta sindical e ampliando a aceitação da ideologia estadonovista de harmonia social via colaboração entre as diferentes classes sociais.

O imposto sindical, instituido pelo Decreto-lei nº 2.377 de 8 de julho de 1940, transformou os sindicatos em órgãos do poder público, cuja função era aproximar a massa não sindicalizada das associações sindicais para realizar em maior amplitude o controle social $^{94}$.

Desse modo, ao caracterizar os sindicatos como órgãos de assistência social, sua função originalmente política de promover a luta de classes ficou em segundo plano. Ao realizar a conciliação entre patrões e empregados os sindicatos passaram a ser peça fundamental na política estadonovista de constituir a paz social e a colaboração entre as classes $^{95}$.

Para caracterizar o elitista governo estadonovista como popular e, assim, legitimá-lo, a ortoga da legislação trabalhista teve enorme importância, pois repremia a manifestação popular de modo velado e quase imperceptível. Sobre esse controle popular, Heloísa Martins escreveu:

“[a política trabalhista] acabou 'servindo admiravelmente à burguesia industrial', garantindolhe condições de acumulação de capital sem que os conflitos e tensões decorrentes do processo produtivo se voltassem exclusivamente contre ela" ${ }^{96}$.

A Consolidação das Leis de Trabalho (CLT), promulgada em $1^{\circ}$ de maio de 1943 pelo Decreto-lei $n^{0}$ 5.452, realizava a valorização do coletivo como entidade detentora dos direitos concedidos pelo Estado em detrimento da categoria de indivíduo,

\footnotetext{
${ }^{94}$ Idem. Ibidem. pp. 232-233.

${ }^{95}$ Idem. Ibidem. p. 64.

${ }^{96}$ Idem. Ibidem. p. 70.
} 
dona de deveres para com a nação construída nos moldes do regime.

A ideologia trabalhista possibilitava ao governo intervir na sociedade de duas maneiras distintas. A primeira constituía no oferecimento de benefícios diretos aos trabalhadores, enquanto a outra correspondia ao simbolismo proporcionado pela lógica da reciprocidade, pois o atendimento às demandas dos trabalhadores era colocado como um ato de generosidade do regime ${ }^{97}$.

Apesar de concordar que a ideologia trabalhista e sindical atuou como uma das bases da ideologia da ordem e paz social promovida pelo Estado Novo, Heloísa Martins ressalvou que na praxis ela contribuiu para realizar uma tomada de consciência no trabalhador:

\footnotetext{
"Mas, ao mesmo tempo que contribuem para a acomodação e alienação do trabalhador, os chamados direitos trabalhistas, ao lado da constante burla por parte do patronado, vão, pouco a pouco, dando ao trabalhador alguma consciência da sua real situação de vida e de suas condições de trabalho, possibilitando uma atuação mais reivindicativa e, até mesmo, radical, ainda que dentro dos limites da política de massas” ${ }^{98}$.
}

Para auxiliar o Estado, considerado a única instituição garantidora da coesão nacional e realizadora do bem público, a desempenhar a sua função e manter a paz, a ordem e a segurança nacional, a censura prévia da imprensa, teatro, cinema e rádio difusão foi instituída na Constituição de 1937, artigo 122, inciso 15, facultando à autoridade competente proibir a circulação, representação ou difusão.

O Departamento de Imprensa e Propaganda (DIP) foi fundado em 27 de dezembro de 1939, fruto dos antecedentes Departamento Oficial de Propaganda (de 2 de julho de 1931) e Departamento de Propaganda e Difusão Cultural (de 10 de julho de 1934). Seu foco era a vida do trabalhador em todas as suas ramificações, interferindo em seu lazer, vida intelectual, trabalho e saúde.

\footnotetext{
${ }^{97}$ GOMES, 1988, p. 327 apud SCHEMES, Claudia. Op. cit., p. 9.

${ }^{98}$ MARTINS, Heloisa Helena Teixeira de Souza. Op. cit.,p. 115.
} 
O DIP era composto por uma diretoria, divisões de divulgação, rádio, cinema, teatro e cinema e subdivisões auxiliares de comunicação, contabilidade, tesouraria, material, filmatoteca, discoteca e bilbioteca (em 1941 acrescentaram-se as seções de pessoal, administração do Palácio Tiradentes, garagem, registro de imprensa e distribuição de propaganda). Cabia ao DIP centralizar os órgãos de propaganda e publicidade dos Ministérios, departamentos, estabelecimentos da administração pública ou entidades autárquicas criados por lei no país ${ }^{99}$.

Desse modo, durante o Estado Novo, o monopólio da força física e da força simbólica encontrava-se em poder do regime, conforme destacou Maria Helena Capelato:

\begin{abstract}
“A propaganda política é estratégica para o exercício do poder em qualquer regime, mas naqueles de tendência totalitária ela adquire força muito maior porque o Estado, graças ao monopólio dos meios de comunicação, exerce censura rigorosa sobre o conjunto das informações e as manipula. O poder político, nesses casos, conjuga o monopólio da força física e da força simbólica. Tenta suprimir, dos imaginários sociais, toda representação do passado, presente e futuro coletivos que seja distinta daquela que atesta a sua legitimidade e cauciona seu controle sobre o conjunto da vida coletiva” ${ }^{100}$.
\end{abstract}

Porém, deve-se sempre considerar a ponderação realizada pela historiadora e não exagerar em nossa análise a força da propaganda política na coaptação popular, pois a sua influência consegue apenas reforçar os sentimentos já presentes na sociedade:

\begin{abstract}
“A análise da utilização dos meios de comunicação como propaganda para divulgação das mensagens políticas, não se pode exagerar sua importância no que se refere ao controle das consciências. As teses que insistem na onipotência da propaganda política não levam em conta o fato de que ela só reforça tendências já existentes na sociedade e que a eficácia de sua atuação depende da capacidade de captar e explorar os anseios e interesses predominantes num dado momento. Cabe lembrar que mesmo os regimes que levaram esse controle ao extremo não conseguiram atingir o objetivo de formar a 'opinião única'. Tal constatação não implica
\end{abstract}

\footnotetext{
${ }^{99}$ MELO e SOUZA, José Inácio. A ação e o imaginário de uma ditadura: controle, coerção e propaganda política nos meios de comunicação durante o Estado Novo. Dissertação de Mestrado - USP. São Paulo, 1990. pp. 182-183.
}

${ }^{100}$ CAPELATO, Maria Helena. "Propaganda política e controle dos meios de comunicação". IN: PANDOLFI, Dulce (Org.). Op. cit., p. 169. 
menosprezo da importância da propaganda política: mesmo sem obter adesão unânime, ela foi um dos pilares de sustentação do poder” ${ }^{101}$.

Nessa prática de controlar o aspecto simbólico da sociedade, censurando temas contrários aos interesses estadonovistas e exaltando outros favoráveis à consolidação de seus ideais, o futebol como elemento de cultura popular, mobilizador de multidões, foi constantemente trabalhado pelo regime, conforme descrição a seguir.

${ }^{101}$ Idem. Ibidem. pp. 177-178. 


\title{
1.2 O Alimento do Organismo Social
}

Para a realização do adestramento social pretendido pelo governo estadonovista em favor da construção nacional, o futebol foi amplamente utilizado para divulgar os valores caros ao regime à multidão por ele aficcionada. O historiador Leonardo Pereira demarcou a utilização do futebol pelo Estado Novo da seguinte forma:

\begin{abstract}
"Cristalizador dos ideais de harmonia social e furor nacionalista que eram propagandeados pelo seu governo após a implantação do Estado Novo, o futebol servia como um grande aliado na disseminação do projeto político que planejava implantar - intensificando e dando sentido mais claro aos intesses que, desde seus primeiros anos, as autoridades governamentais manifestaram em relação ao jogo ${ }^{102 ”}$.
\end{abstract}

No início do século XIX, com o crescimento urbano e a decorrente formação das grandes metrópoles, as autoridades políticas iniciaram seus investimentos em educação física e esportes para disciplinar o coletivo.

Em 1882, Rui Barbosa introduziu nas escolas a prática da educação física e o Colégio São Luíz, em Itú, inspirado nos colégios europeus, colocou o futebol em sua grade curricular objetivando disciplinar seus alunos ${ }^{103}$.

Nesse período, buscou-se incutir no indíviduo, desde a sua infância, um condicionamento corporal, reações automatizadas para ajustar o sujeito do modo mais perfeito possível, as contingências e solicitações físicas do ambiente urbano ${ }^{104}$.

De acordo com Hilário Franco Junior, a própria normatização do futebol ocorrida em Londres, no ano de 1863, aconteceu com o propósito de manter a ordem social, dominar o corpo e fazê-lo trabalhar em favor da sociedade local. O futebol

\footnotetext{
102 PEREIRA, Leonardo. Footballmania. Uma história social do futebol no Rio de Janeiro, 1902-1938. Rio de Janeiro: Nova Fronteira, 2000. p. 335.

103 SANTOS NETO, José Moraes dos. Visão do jogo. Primórdios do futebol no Brasil. São Paulo: Cosac \& Naify, 2002. p. 18.

104 SEVCENKO, Nicolau. "Futebol, metrópoles e desatinos”. Revista USP, n 22, p. 30-37, jun./jul./ago, 1994. p. 34.
} 
moderno, em seus primórdios, foi pensado pelas elites inglesas para constituir uma microsociedade igual à sociedade inglesa na qual ele foi construído ${ }^{105}$.

Na sociedade brasileira, a cultura esportiva disseminou-se no final do século XIX quando as grandes metrópoles foram constituídas. Anteriormente, na sociedade colonial pouco dinâmica e sem vida cultural, as associações esportivas não conseguiram vingar, devido a quase inexistência de redes de sociabilidade no período ${ }^{106}$.

A tríade dos novos tempos, de acordo com o historiador Nicolau Sevcenko, passou a ser composta pela regeneração urbanística, modernidade e os esportes. Sobre a truculência presente no processo de “regeneração” do Rio de Janeiro, Sevcenko observou:

\begin{abstract}
“Graças a essa intensificação dos laços neocoloniais e ao prodigioso afluxo de riquezas decorrentes, alguns subiam na escala social e outros, literalmente, subiam expulsos para os morros da cidade" ${ }^{107}$.
\end{abstract}

A vinculação dos esportes à noção de uma vida saudável, atrelado ao ideário burguês proveniente da Europa onde os esportes eram tidos como um fator civilizador $^{108}$ propagaram a cultura esportiva na sociedade brasileira, pois o elemento estrangeiro era considerado moderno e, assim, querido pela elite:

“Essa expressão ‘civilização esportiva' portanto não deve ser entendida como se referindo exclusivamente à prática generalizada de diferentes modalidades de esporte, mas à generalização de uma ética do ativismo, a idéia de que é na nação e portanto no engajamento corporal que se encontra a mais plena realização do destino humano. As filosofias da ação, os homens de ação, as doutrina militares, os atos de arrebatamento e bravura se tornam os índices os quais as pessoas passam a se inspirar e pelos quais passam a se guiar”" ${ }^{109}$.

\footnotetext{
${ }^{105}$ FRANCO JUNIOR, Hilário. Op. cit., p. 28. urbana do Rio de Janeiro”. Estudos Históricos. Rio de Janeiro, v. 13, n 23, p. 17-39, 1999. p. 21. 1998.

${ }^{108}$ Cf. ELIAS, Nobert. O processo civilizador. v. 2. Rio de Janeiro: Zahar, 1994.

${ }^{109}$ SEVCENKO, Nicolau. Op. cit., p. 568.
}

106 JESUS, Gilmar Mascarenhas de. "Construindo a cidade moderna: a introdução dos esportes na vida

107 SEVCENKO, Nicolau. “O prelúdio republicano, astúcias d ordem e ilusões do progresso”. IN: NOVAIS, Fernando A. (Coord.). História da vida privada no Brasil. 3 vol. São Paulo: Cia dos Livros, 
Nessa febre esportiva, fruto da modernidade que valorizava a saúde físicomuscular e os cuidados com a higiene, enquanto o futebol era praticado de modo amador pela elite das grandes metrópoles brasileiras, os setores populares formavam seus times de futebol na várzea, sem equipamentos próprios, apenas utilizando a imitação e o talento para jogar ${ }^{110}$. Os esportes passaram a ser signos de distinção nesse novo cenário social, no final do século XIX:

\begin{abstract}
"Nesse contexto o esporte, e tudo que traga as suas conotações, se torna de fato um dos códigos mais expressivos para fortalecer os signos de distinção social. Ele surgiu e se impôs como um ritual elitista, revestido de valores aristocráticos do ócio, do adestramento militar e do sportmenship (cavalheirismo, imparcialidade e lealdade). Ao se apropriar dele a burguesia o traduzia em termos de agressividade, competividade e imperativo de vitória. O seu prestígio crescente garantiu que as convenções prosseguisem ao longo da escala social. Daí a sua rápida popularização de fins do século XIX até o boom dos anos 20"111.
\end{abstract}

Essa prática popular foi aos poucos sendo reconhecida pela imprensa e pelos clubes que passaram a contratar bons jogadores para atuar em seus times e disputar os campeonatos amadores mediante o pagamento em dinheiro ou com oferta de empregos em fábricas e atividades comerciais. ${ }^{112}$

Ao encontro dos ideais antropofágicos pensados pelo movimeto modernista na década de 20 do século passado, o futebol e seus fundamentos estrangeiros foram reapropriados pelas classes populares brasileiras, conferindo a este um outro dinamismo e especificidades próprias da cultura brasileira ${ }^{113}$.

\footnotetext{
${ }^{110}$ FRANCO JUNIOR, Hilário. Op. cit., p. 63.

${ }^{111}$ SEVCENKO, Nicolau. Op. cit., p. 575.

${ }^{112}$ Sobre o falso amadorismo no futebol, ou “amadorismo marrom” ver: CALDAS, Waldenyr. O pontapé inicial. Contribuição á memória do futebol brasileiro (1894-1933). Tese de Livre Docência - ECA/ USP. São Paulo, 1988; FRANCO JUNIOR, Hilário. Op. cit., p. 28. Cap. 2; RODRIGUES FILHO, Mario. Op. cit., Cap. II e ROSENFELD, Anatol. Negro, macumba e futebol. São Paulo: Edusp/ Perspectiva/ Editora da Unicamp, 1993. p. 80-88. Para uma análise sobre o sistema de pagamento do jogador proveniente com uma oferta de emprego e um salário mediante essa atividade profissional: ANTUNES, Fátima Martin Rodrigues Ferreira. Futebol de fábrica em São Paulo. Dissertação de Mestrado - FFLCH/ USP. São Paulo, 1992.

${ }^{113}$ WISNIK, José Miguel. Op. cit., p. 181.
} 
Nicolau Sevcenko refletiu sobre o poder sedutor do futebol junto às classes trabalhadoras. Um dos motivos estaria na própria constituição das metrópoles, onde pessoas de diferentes lugares, sem traços em comum ou tradições foram atraídas após a revolução científico-tecnológica. Caberia ao futebol, nesse raciocínio, com suas características ritualísticas, unir esses diferentes indivíduos criando traços identitários e uma sociedade coletiva ${ }^{114}$.

Outra explicação para a sedução futebolística seria o seu próprio poder gregário. Sua característica coletiva, a semelhança física dos seus jogadores com os indivíduos da classe trabalhadora, o fato de não utilizar materiais específicos para sua prática e a sua imprevisibilidade que cria uma sensação no torcedor de poder tomar os rumos da partida, estabelecem uma cumplicidade entre seus praticantes e a massa trabalhadora.

Ainda sobre popularização do futebol, Roberto DaMatta realizou uma interessante análise sobre o assunto vislumbrando a apropriação do jogo pela massa raciocinando inversamente a Sevcenko: por que a elite teria abandonado esse esporte? Sobre esse movimento inverso, contraponto da motivação popular pelo jogo de futebol, DaMatta escreveu:

\begin{abstract}
"Ao contrário, elas [as elites brasileiras] odeiam o jogo. Por quê? Porque certamente o jogo significa basicamente ter que se submeter a regras que valem para todos. Realmente, o ponto crítico e o traço distintivo do jogo é a noção fundamental das regras para todos e uma aceitação da idéia de justiça (que legitima o perdedor e o ganhador) e individualidade (quem perde é você, não a sua classe, família ou segmento social). Tudo isso, eu sustento, o futebol apresenta de modo implícito e humildemente a uma sociedade que tem jogado muito mal pelas regras universais. Assim, em vez do jogo, temos em geral ritualizações onde os poderosos sempre inventam novas regras e modificam drasticamente o jogo" ${ }^{115}$.
\end{abstract}

A popularização do futebol também pode ser analisada pela concepção do jogo

\footnotetext{
${ }^{114}$ SEVCENKO, Nicolau. Op. cit., p. 35.

${ }^{115}$ DAMATTA. Roberto (Org). Op. cit., p. 16.
} 
como uma atividade alienante ${ }^{116}$, conforme salientou o historiador Leonardo Pereira. Ao analisar as explicações tecidas por Joel Rufino dos Santos em seus textos sobre os motivos que formentaram o processo de massificação do futebol, Pereira as criticou como formulações exógenas a dinâmica do jogo:

\begin{abstract}
"O que em São Paulo seria um esporte que, patrocinado pelos industriais, equivaleria a um ensinamento de disciplina e de harmonia, assumia, assim, no Rio de Janeiro a feição de um poderoso instrumento de alienação, capaz de distrair os trabalhadores de seus problemas e difilculdades. Nos dois casos discutidos pelo autor [Joel Rufino dos Santos] o futebol aparece portanto, como um elemento externo à experiência daqueles que o praticavam: como imposição ou como dádiva, é pelas mãos de seus algoses que os trabalhadores do período interessar-se-iam pelo jogo da bola”" ${ }^{117}$.
\end{abstract}

Outro exemplo sobre a popularização do futebol como processo vinculado à

tentativa da classe dominante de controlar a massa foi elaborado por Juan Sebreli:

\begin{abstract}
“Desde el Imperio Romano con su lema 'pan y circo', el espetáculo deportivo ha sido usado por el poder politico como compensación simbólica le las miséiras de la vida cotidiana. En el mundo actual el fútbol - como tambiém el rock - es utilizado como medio de adiestramiento gregario, de control psicológico, através de reflexos condicionados, como un señuelo para alejar a las massas y a la juventud de la reflexión sobre los problemas reales” ${ }^{118}$.
\end{abstract}

\title{
Considerações à parte sobre a massificação futebolística, com a
}

profissionalização dos esportes e sua propagação à multidão graças ao rádio e aos

periódicos, o futebol se concretizou na sociedade como um esporte nacional capaz de

sensibilizar tanto os setores elitistas (seus primeiros praticantes), como os populares.

Sobre o incremento da imprensa esportiva, após o início das transmissões das

\begin{abstract}
${ }^{116}$ Como exemplo de literatura onde o futebol foi analisado estritamente como elemento alienante da classe trabalhadora, destaca-se o livro escrito por Roberto Ramos. Utilizando a teoria marxista e analisando o espaço concedido ao futebol pelo jornal Zero Hora e Folha da Tarde, a programação esportiva da Rede Bandeirantes de Televisão e a Rádio Gaúcha e Guaíba, de Porto Alegre, o autor interpretou o futebol como um instrumento ideológico utilizado pela burguesia para alienar o trabalhador da sua condição de explorado pelo sistema capitalista. RAMOS, Roberto. Futebol. Ideologia do poder. Petrópolis: Vozes, 1984. Para outra referência bibliográfica, Cf. SEBRELI, Juan José, 2005.
\end{abstract}

${ }^{117}$ Para Joel Rufino dos Santos, o que motivou a popularização do futebol em São Paulo, fomentada pelos industriais, foi a necessidade de manter os operários afastados da atividade sindical. Sob o mesmo raciocínio, a acessibilidade popular à prática futebolística no Rio de Janeiro foi um importante instrumento para coibir a prática da capoeira, pois proporcionava na massa o gosto por uma luta mais regulamentada. SANTOS, Joel Rufino. História política do futebol brasileiro. São Paulo: Brasiliense, 1981 apud PEREIRA, Leonardo. Op. cit., p. 204.

${ }^{118}$ SEBRELI, Juan José. Op. cit., p. 155. 
partidas de futebol, via rádio, Leonardo Pereira escreveu:

"Não era de se estranhar que, segundo uma publicação oficial de 1931, a imprensa esportiva tivesse sido a que maior incremento alcançara nos anos anteriores, saltando de 5 jornais em 1912 para 58 em 1930 - em um crescimento que, chegando aos 1060 \% era imensamente maior do que aquele verificado pelos jornais noticiosos de forma geral, que fora de apenas 72,2 \%. Surgiram nesse movimento folhas diárias dedicadas ao futebol como o Rio Sportivo, fundado em 1926, o Jornal dos Sports e o Mundo Sportivo, criado em 1931, pelo próprio Mário Filho" ${ }^{119}$.

Os meios de comunicação construíam e propagavam cotidianamente as “formas-representações” ${ }^{120}$ presentes no futebol, trascendendo os limites espaciais e temporais do evento esportivo, tornando-o um "fato da sociedade" ao estabelecer uma complexa trama entre as dimensões rituais e cotidianas ${ }^{121}$.

Nessa presença cotidiana do ritual futebolístico se estabelecia uma “sociabilidade por distanciamento”, pois grupos e relações identitárias eram constituídos mesmo após o final da partida. Esses diferentes agrupamentos estimulados pela própria natureza competitiva do esporte viviam em constante disputa por espaços sociais ou simbólicos ${ }^{122}$.

Sobre o poder inerente ou patrocinado do futebol em criar signos de pertencimentos entre os torcedores e seus clubes ou nação, Arlei Damo escreveu:

"O processo de investimento possui dupla face e pressupõe, entre outras coisas, um trabalho de mediação entre o time e a nação. É preciso fazer crer à comunidade de sentimento que aquele time representá-a, bem ou mal, e isso implica um jogo de sedução. O futebol foi, no seu conjunto, investido desse poder simbólico ao longo de mais de um século e, em razão disso, os mediadores especializados encontram, no presente, uma base considerável de investimentos já realizados (...) que, em outras épocas, foi patrocinada pelos Estados-nações, por intermédio de suas agências de propaganda, e em certos casos, ainda é” ${ }^{123}$.

\footnotetext{
${ }^{119}$ PEREIRA, Leonardo. Op. cit., p. 317.

${ }^{120}$ Para Toledo, as “formas-representações” próprias do futebol são constituidas a partir da tática, estilo e simbologia do jogo, como o “jogar à brasileira”, “futebol arte” ou o "São Paulo de Têle”. Elas seriam categorias móveis de interpretação, pois dependem do consenso entre o especialista, torcedor e profissional. TOLEDO, Luíz Henrique de. Lógicas no futebol. Dimensões simbólicas de um esporte nacional. Tese de Doutorado - Antropologia Social/ USP. São Paulo, 2000. pp. 164-165.

${ }^{121}$ Idem. Ibidem. p. 193.

${ }^{122}$ Idem. Ibidem. p. 276.

${ }^{123}$ DAMO, Arlei Sander. Do dom à profissão. Formação de futebolistas no Brasil e na França. São Paulo:
} 
Graças à coerção social praticada pelo Estado Novo, o modo como o futebol era compreendido e praticado foi alterado, ajustando-se às características dos novos moldes sociais. Assim, o habitus do futebol no país variou de acordo com as diretrizes implementadas pelo governo estadonovista para o qual trabalho, coletivismo e harmonia eram os pontos balizadores.

Conforme teorizou Mauss, esse habitus varia de acordo com a prática coletiva influenciada pela educação socialmente recebida pelos indivíduos, e não simplesmente pelas repetições realizadas por esses. Os atos formadores desse habitus reúnem características físico-mecânicas, anatômico-fisiológica e pscico-sociológica, ou seja, ele constitui-se como fato social total em sua coletividade integradora ${ }^{124}$.

Sendo assim, o futebol colocaria em ação a totalidade das sociedades e suas instituições. Analisando esse esporte foram vilumbrados, concomitantemente, os âmbitos jurídico, econômico, religioso, estético, linguístico e todas as demais áreas formadoras da cultura das quais ele faz parte e interage.

Isso ocorre devido à inexistência de uma “maneira natural” de praticar um esporte. As técnicas corporais seriam atos transmitidos por meio de uma tradição, ou seja, são construídas historicamente, por relações conflituosas entre as diferentes classes sociais $^{125}$.

Nessa construção histórica da prática esportista, de acordo com Luiz Henrique Toledo, apesar de as regras do jogo serem universais, elas são interpretadas socialmente, ou seja, são “climatizadas” de acordo com as necessidades de quem pratica o jogo:

“... as sucessivas aclimatações às regras, a princípio nocivas aos propósitos universalistas do Aderaldo \& Rothschild Editores/ Anpocs, 2007. Versão em Tese de Doutorado, p. 319.

${ }^{124}$ MAUSS, Marcel. Sociologia e antropologia. Rio de Janeiro: Cosac \& Naify, 2003. p. 404.

${ }^{125}$ Idem. Ibidem. p. 405. 
futebol, estimularam, ao mesmo tempo, uma fragmentação de estilos de jogar mais condicionados às variabilidades locais impostas pelos interesses, percepções, leituras e entendimentos dessas mesmas regras, alterando as padronizações e conferindo plasticidades e emoções variadas à sua fruição, dentro e fora do campo de jogo" ${ }^{126}$.

Além das regras construídas historicamente, para Toledo, o jogo de futebol teria uma "segunda" e "terceira natureza" que auxiliam no rompimento dessa pretensa universalidade, própria do caráter universal do jogo, a saber: as “formas" e “representações”:

"Desse modo, as regras não determinam ou instruem totalmente as maneiras de jogar, o que revela nas formas uma espécie de 'segunda natureza' do esporte, ambas acopladas ainda a uma 'terceira natureza', identificada nas representações que consolidam as anunciadas 'escolas', 'jeitos' ou 'estilos', categorias nativas em relação que determinam os modos de conceber e vivenciar o futebol praticado em várias partes do mundo, ou mesmo dentro de um país, como parece ser o caso do brasileiro ao anunciar várias escolas...” 127.

As formas de jogar seriam combinações numéricas que formatam o posicionamento e a incumbência dos jogadores dentro de campo ${ }^{128}$. Esses padrões de jogo ao visarem a melhores performances formentam a rivalidade própria do esporte e mobilizam uma maior quantidade de aficcionados ${ }^{129}$. Para Arlei Damo, resumidamente, essas formas e padrões de jogo seriam as diferentes maneiras de ocupar o tempo e o espaço durante a partida:

"Da gestão do espaço e do tempo, surgiram as formas/padrões de jogo referidos como o '3-43', o '4-3-3', o '3-5-2' e outras variações possíveis, porém limitadas. Tais formas/padrões nada são além de estratégias de ocupação dos espaços e fazem parte da cultura futebolística - os profissionais usam, seguidamente, o termo ‘cultura tática' para referirem o domínio prático ou discursivo dessa modalidade de dispositivo. Atuar de acordo com as formas/padrões é ensinado e aprendido ao longo da formação profissional, como uma modalidade de capital futebolístico. Trata-se de uma estratégia de divisão dos espaços entre os diferentes membros da equipe. Em conceito sociológico, as formas/padrões de jogo seriam princípios de divisão social do trabalho e, por extensão, de especialização" ${ }^{130}$.

Assim, de acordo com Toledo, para analisar o futebol deve-se ter em mente as

\footnotetext{
${ }^{126}$ TOLEDO, Luíz Henrique de. Op. cit., p. 60.

${ }^{127}$ Idem. Ibidem. p. 71.

${ }^{128}$ Idem. Ibidem. p. 70.

${ }^{129}$ Idem. Ibidem. p. 77.

${ }^{130}$ DAMO, Arlei Sander. Op. cit., p. 307.
} 
regras e as formas de jogar culturalmente aceitas e não somente suas representações de “jeito" e "estilo":

"Porém, é preciso advertir, somente o jeito ou o estilo, que se revelam num repertório bastante heteróclito de categorias nativas muito em voga, tais como as noções de ginga, malícia, raça, virilidade de um povo, não definem exclusivamente o futebol por ele praticado, como querem as análises excessivamente culturalistas, que muitas vezes divorciam as representações engendradas em torno do futebol, da sua evolução técnica, individual e coletiva. Há uma contiguidade entre essas "três naturezas", ou seja, entre as regras, as formas de jogar e estas categorias nativas, que consolidam representações socialmente aceitas" ${ }^{131}$.

Nesse raciocínio, a própria definição de quais elementos seriam apreciados no

futebol por seus participantes, em determinadas culturas, igualmente constrói-se

historicamente. Sobre essa construção estilística, escreveu Damo:

"Sendo a prática e a apreciação do futebol apreendidas concretamente, o esquadrinhamento do espaço e do tempo tornou-se, seguidamente, naturalizado aos olhares dos praticantes e observadores. Entretanto, nada há de natural no posicionamento das equipes, nem mesmo no sentido preferencial das suas ações”, ${ }^{132}$.

Desse modo, pode-se pensar se realmente o futebol brasileiro tem um estilo,

um jeito próprio de ser praticado. Não seria esse estilo um discurso engendrado para

demarcar algumas noções de diferenciação e identidade, já que a prática esportiva é influenciada pela tradição, ou seja, construída socialmente ao longo dos tempos?

Analisando essa questão Arlei Damo escreveu:

“Os estilos são constitutivos das propriedades dos jogos. Ao considerá-los enquanto tal, implica dizer que eles são objeto de interesse dos agentes sociais e sujeitos à criação e recriação (...) Os estilos do jogo, quaisquer que sejam, são objeto de interesse dos agentes sociais, porém não o são indistintamente. Assim como as formas/padrões interessam, prioritariamente, aos profissionais (jogadores, técnicos, etc) e aos mediadores especializados (comentaristas, sobretudo), os estilos importam a determinados públicos (torcedores, intelectuais, etc) e, particularmente, em dadas circunstâncias (Copas do Mundo, por exemplo)” 133 .

Essa formulação estética em torno do futebol brasileiro foi construída a partir da dicotomia dom versus técnica. Para os parâmetros de estilo brasileiro, o verdadeiro

\footnotetext{
131 TOLEDO, Luíz Henrique de. Op. cit., p. 79.

${ }^{132}$ DAMO, Arlei Sander. Op. cit. p. 305.

${ }^{133}$ Op. cit., p. 315.
} 
jogador habilidoso tem um dom natural com a bola. Ele não foi fabricado pela repetição de treinos que lhe conferiram um refinamento técnico. Em seu estudo de doutorado, Toledo formulou a seguinte consideração sobre o “estilo” ser um “dom” inato:

“Estilo também remete à idéia de 'jeito’, evocando, inclusive, outras dimensões do universo simbólico, tão caro à cultura esportiva brasileira. Quando se diz que um determinado jogador possui estilo está referindo a um “dom” recebido, revelado muitas vezes na fala dos jogadores como uma dádiva ou benção divina” ${ }^{134}$.

Outro importante estudo sobre o dom como elemento vinculado ao capital futebolístico foi desenvolvido por Damo, no livro citado anteriormente. Para o autor, o “dom” pode ser concebido como talento ou como dádiva. No primeiro caso, ele seria algo inato ao sujeito e tem a possiblidade de ser aperfeiçoado. No segundo modo, ele precisa circular entre os grupos que o reconhecem e o manipulam, ou seja, as mesmas configurações sociais que geram o dom são as responsáveis por orientar a sua manipulação e circulação ${ }^{135}$.

Assim, de acordo com Arlei Damo, para existir a noção de dom foi necessário ocorrer o seu reconhecimento pelo público e pelos demais envolvidos na atividade futebolística:

\begin{abstract}
“... pois o dom não sugere substância, mas relação, troca, circulação (...) O dom futebolístico que está na origem de todos os investimentos, uma vez aperfeiçoado e reconhecido pelo público, entra em circulação suscitando uma cadeia de trocas que, por seu turno, implicam a sua reconversão incessante, em forma de dinheiro e afeto, interesses individuais e coletivos, fidelidade e traição, idolatria e escárnio, enfim, em uma miscelânia de eventos e símbolos. Estamos tratando de dom/dádiva, um dom com sentido ubíquo - ao contrário do dom/talento, claro e manifesto - e, ao que tudo indica, no terreno da reciprocidade” ${ }^{136}$.
\end{abstract}

No processo construtivo de um estilo brasileiro de jogar futebol, imbricou-se à noção de dom e facilidade intrínseca do jogador no lidar com a bola, a ideia de gingado, molejo, refinamento artístico e malandragem. Sobre essa característica brasileira de

\footnotetext{
${ }^{134}$ TOLEDO, Luíz Henrique de. Op. cit., p. 101.

${ }^{135}$ DAMO, Arlei Sander. Op. cit., p. 186.

${ }^{136}$ Idem. Ibidem. pp. 193-194.
} 
praticar o "futebol-arte" e a diferença entre esse estilo e o "futebol-força”, DaMatta escreveu:

"O futebol-arte é representado de maneira totalmente outra. Para ele contam habilidade, espontaneidade, toque-de-bola e malícia. Estas qualidades não se aprendem no colégio. São naturais no jogador brasileiro. A capacidade de improvisar e o talento individual produzem um futebol de beleza e exibição. Para que possam existir todos esses atributos, tem de haver descontração tática. O jogador brasileiro tem ginga, versatilidade e intuição, por isso é um artista.

O confronto dos dois paradigmas é instrutivo. O $1^{\circ}$ propõe um modelo voltado para a eficácia empírica. Todos são iguais e subordinados a um esquema nacional, assimilado e expresso na disciplina. A aplicação e economia são as armas do sucesso. O outro modelo se baseia em qualidades tidas como naturais. A ginga nasce com o indivíduo. O gênio pessoal é indispensável. Sem ele, o futebol perderia a sua qualidade expressiva. Perderia a graça da criatividade estética gratuita, e com ela, o prazer da exibição e da contemplação” ${ }^{137}$.

Conforme destacou Damo, não se pode perder de vista que a afirmação de um estilo brasileiro próprio de jogar futebol foi construída no imaginário da nação graças à intensa quantidade de discursos engendrados nesse sentido por torcedores e especialistas, e não propriamente devido ao processo miscigenador ou qualquer outro fato presente na formação nacional ${ }^{138}$.

Mesmo porque, as características hoje exaltadas como intrínsecas ao futebol brasileiro, no período estadonovista eram consideradas nocivas aos esportes nacionais e duramente combatidas pelo governo por meio dos discursos publicados nos meios de comunicação (controlados pela censura, no período).

Assim, durante o Estado Novo exaltou-se o futebol praticado harmonicamente, no qual o conjunto era mais valorizado, em detrimento do craque individual. A eugenia, valorização da família e da mulher como agente fundamental para a sua constituição, a burocratização e a normatização dos principios futebolísticos foram outras características trabalhadas pelo regime para serem enraizadas na sociedade brasileira e no futebol vivido por essa.

\footnotetext{
${ }^{137}$ DAMATTA. Roberto (Org). Op. cit., p. 109.

${ }^{138}$ DAMO, Arlei Sander. Op. cit., p. 323.
} 
Desse modo, instalava-se um mal estar súbito, um desconforto entre o ideal esportivo defendido pelo governo afim com o seu projeto de nação e o jogo habitualmente praticado profissionalmente, responsável por levar milhares de espectadores aos estádios. Como escreveu Damo, o futebol refletia uma imagem de nação deformada em relação àquela projetada pelas classes dominantes:

"O que o time de onze brasileiros vestindo verde e amarelo faz não é apenas espelhar, mas deformar, quase sempre para melhor, a imagem que a nação faz de si mesma. Como o futebol brasileiro é identificado, não por acaso e sim porque é investido, com os segmentos dominados na economia e na política, seu poder simbólico de rendição é potencializado, seduzindo não apenas os excluídos, bem como uma parte da intelectualidade. Desde os anos 30, talvez, a seleção brasileira é aclamada por praticar o futebol-arte, ou por não praticá-lo, desvirtuando-se ou reencontrando-se com suas próprias origens" 139.

Apesar do controle realizado pelo governo por decretos ou por divulgação da função social dos esportes nos periódicos do período ${ }^{140}$, o futebol profissional era realizado de modo individualista, com atuações voltadas ao espetáculo e não necessariamente ao rendimento ou à obediência tática.

Esse conflito entre a prática futebolística e os ideias governistas estava presente na construção de um estilo brasileiro de jogar futebol, como demonstra a ambiguidade existente no período sobre o fato da miscigenção brasileira ser ou não considerada um bom componente. Assim, a negritude, o descompromisso, o individualismo e a ginga mulata ficavam em constante tensão com a burocratização do esporte formentada pelo Estado Novo:

\begin{abstract}
“A ideologia da miscigenação, que se firmou nos anos 30, valorizou a fusão das raças e das culturas que deram origem ao povo brasileiro. A partir da idéia de síntese racial e cultural, chegou-se à definição de uma identidade nacional, ou de traços de personalidade que definiam o caráter nacional brasileiro. Atributos como brejeirice, ginga, astúcia, simplicidade e outros também foram reconhecidos na maneira ou no estilo brasileiro de jogar futebol. Contudo, não se deve confundir estilo com padrão de jogo. Historicamente, o futebol brasileiro sempre adotou o esquema tático mais comum à época. Assim foi com o 2-3-5, com o 4-2-4 e suas
\end{abstract}

\footnotetext{
${ }^{139}$ Idem. Ibidem. p. 320.

${ }^{140}$ Esse tema será tratado com mais vagar no Capítulo III: A voz da ordem, na presente dissertação de mestrado.
} 
variações” ${ }^{141}$.

Com o desenquadramento entre o ideal futebolista proposto pelo governo, calcado na disciplina e harmonia, e o jogo praticado dentro de campo e vivenciado cotidianamente pelos torcedores, foram inúmeras as notícias publicadas nos periódicos paulistas e cariocas sobre violência durante as partidas:

\begin{abstract}
"Vale recordar os feios sucessos. As coisas começam lá pelo $1^{\circ}$ quarto de hora, quando o juiz puniu o time carioca com uma pena máxima. Pixim segurou a bola em plena área. Penal legítimo e assinalado pelo árbitro. Os sancristovenses com Veliz à frente, protestaram e fizeram roda em torno do juiz. Gritaram. Ameaçaram. Policiais em campo. Um deles desembanhou a espadim e interpelou o árbitro (...) Aos 39 minutos eles disputaram a bola nas proximidades da área carioca e o ponteiro santista levou a pior. Parece que Jorginho, mesmo caído, pisou Pelado, o qual revidou prontamente, socando o rosto do jogador local. Ambos foram expulsos. E logo depois, Índio, o atlético centro-médio carioca, agrediu Eunápio. Eunápio não reagiu, porque é futebolista correto, de boa disciplina. Pois bem. O juiz foi além de sua decisão. Mandou que o agressor e o agredido se retirassem de campo (...) [No segundo tempo de jogo] Vários jogadores se engalfinharam. Jorge Miguel, o rotundo apitador, também entrou no barulho. Recebeu um pontapé de Magalhães, mas revidou com outro pontapé. Entretanto, cofundiu-se, o árbitro ordenou a expulsão de Nestor, que nada tivera com a briga, sendo, por sinal, uma dos mais disciplinados jogadores do Rio de Janeiro (...) Dois minutos depois, o mesmo Magalhães provocou nova desordem. Dessa vez, Jorge Miguel expulsou-o. E o que fez o ponteiro direito carioca? Foi até a grade, desfez-se do gorro e voltou ao campo, colocando-se muito de indústria na extrema esquerda. Jorge Miguel não pecebeu (...) Veliz no arco, instigava seus companheiros à desordem. Tripudiava dos adversários toda vez que a bola lhe caia às mãos. Houve nova interrupção. Todos os jogadores se reuniram em campo, discutindo, ameaçando, gritando. E Índio e Celado, já expulsos, voltaram ao campo para brigarem..." 142 .
\end{abstract}

Na notícia em destaque, fica clara a falta de harmonia e disciplina dentro de campo entre os combatentes. Além disso, a violência empregada pelos jogadores deixou exacerbados dois fatores fortemente repudiados pelo governo, por serem contrários ao ideal de nação, a saber: o individualismo e o regionalismo.

A própria questão racial merece ser analisada mais cuidadosamente, pois apesar de a maioria dos futebolistas serem negros ou mestiços, o governo estadonovista transmitia os seus ideais eugênicos por meio do futebol. Uma hipótese para explicar essa utilização do futebol profissional pelo regime para concretizar o seu projeto de

\footnotetext{
${ }^{141}$ ANTUNES, Fátima Martin Rodrigues Ferreira. Op. cit., p. 32.

${ }^{142}$ O jogo que a notícia fez referência foi um amistoso disputado em Santos, na Vila Belmiro, entre Santos F C e São Cristovão F C. Gazeta Esportiva, 24 de fevereiro de 1945.
} 
caldeamento étnico consiste no processo de valorização da mestiçagem brasileira, em voga no período com Gilberto Freyre ${ }^{143}$.

Sobre esse processo de exaltação à miscigenação, Roberto DaMatta nos esclareceu que, após a abolição da escravidão, a hierarquização e diferenciação social passou a se dar pelo uso do corpo:

\begin{abstract}
“A teoria do corpo, especialmente a partir da Abolição, passou a ser racismo à brasileira, dotados de dois fatores distintos: um, onde ele era tipicamente hierarquizado e rígido, logo após a abolição, quando, de fato, o problema se coloca (Cf. Skidmore, 1976), E outra, que entra em vigor a partir da publicação da obra de Gilberto Freyre, orientada não para o ponto de partida ou de chegada dos sistemas (respectivamente, o negro atrasado e debil e o branco civilizado), mas para seus interstícios. Temos, como consequência, a glorificação da miscigenação, do mestiço e da mulataria. Mas não se pode esquecer que, em ambas, é o corpo o elemento central da elaboração ideológica, formando a unidade básica do plano hierarquizador" ${ }^{144}$.

O enaltecimento da figura mestiça no processo de formação racial brasileira,
\end{abstract} durante o Estado Novo, possibilitou aos futebolistas negros e mestiços provenientes, em sua maioria, dos setores pobres da sociedade concretizarem a sua ascensão social e a popularização do esporte mesmo porque, a maioria dos torcedores se identificavam com tais profissionais da bola, pois além de serem negros e mestiços eram igualmente provenientes dos setores subalternos da sociedade.

Ao criticar uma tese de doutorado, cujo tema era o livro $O$ negro no futebol brasileiro, escrito por Mário Filho, Ronaldo Helal e César Gordon Junior, concordaram com o jornalista carioca ao demarcar o futebol, durante o Estado Novo, como um dos raros espaços em que negros e mestiços poderiam conseguir a ascenção social:

“... [o futebol] é ao mesmo tempo um dos únicos domínios de que negros e mulatos dipõem para ingressar no sistema econômico brasileiro; matéria- prima de um discurso de integração nacional; e objeto de massificação e popularização. Não resta dúvida de que todos esses fatores se encontraram no futebol a partir da década de 30 e serviram, de vários modos, para torná-lo o

\footnotetext{
143 A valorização da mestiçagem dependia, em muito, de como o negro ou mestiço se comportava socialmente. Para ser destacado, caberia a ele atuar de acordo com os ideais do regime, ou seja, com disciplina, ordem e coletivamente. Sobre isso ver o capítulo II - Os trabalhadores da bola.

${ }^{144}$ DAMATTA. Roberto. Op. cit., p. 154.
} 
‘esporte nacional” 145 .

A ideia de constituir uma raça pura, realizar o caldeamento étnico da população brasileira predominantemente mestiça ligava-se à construção da nação brasileira idealizada pelo regime. Nesse contexto, a despeito da grande quantidade de jogadores negros e mestiços no futebol, esse esporte foi colocado como elemento inspirador de eugenia e formador da raça forte, por meio de uma propaganda enaltecedora da disciplina, força física e técnica presentes no futebol.

Nessa missão de enquadrar a imagem da nação nos moldes propostos pelo regime estadonovista, a Educação Física foi implementada nas escolas públicas para auxiliar o adestramento social e fortalecer o corpo da nação. Os grandes desfiles de colegiais perfilados militarmente para enaltecer o governo, a valorização do trabalhador em detrimento da figura do malandro e o enaltecimento do jogo coletivo e disciplinado sem fortalecer a imagem dos craques individuais e rebeldes, confirmam a tentativa do governo de construir uma nação eugênica, sadia e disciplinada.

Em sua tese de doutorado, Plínio Negreiros escreveu sobre a aproximação da Educação física com a disciplina militar, durante o Estado Novo:

\begin{abstract}
“A introdução dessa área de conhecimento se deu nas escolas de formação militar e as primeiras escolas para a formação de pessoal especializado em Educação Física vinculavam-se ao Exército e à Marinha. Assim, grande parte das teorias da Educação Física eram militares. Explica-se, pois, que a Diretoria de Esportes do Estado de São Paulo estivesse nas mãos do tenente Sylvio de Magalhães Padilha, ou que a direção e os principais cargos da revista Educação Física, estivessem em poder de militares” ${ }^{146}$.
\end{abstract}

Nesse sentido, escreveu o historiador que o esporte era compreendido como uma forma de educar o corpo para o trabalho e como elemento básico na busca pelo

\footnotetext{
${ }^{145}$ O texto realizou uma crítica à tese de doutorado defendida em 27 de março de 1998, por Antônio Jorge Soares, na Universidade Gama Filho, sob o título Futebol, raça e nacionalidade no Brasil: releitura da história oficial. HELAL, Ronaldo e GORDON, César. "Sociologia, História e Romance na construção da identidade nacional através do futebol”. Estudos Históricos. Rio de Janeiro, v. 13, n 23, p. 147-165,1999. p. 158.

${ }^{146}$ NEGREIROS, Plínio José Labriola de Campos. A nação entra em campo: Futebol nos anos 30 e 40. Tese de Doutorado - História/ PUC-SP. São Paulo, 1998. p. 154.
} 
progresso:

“... numa questão de fundo: a construção da nação a partir do melhoramento do corpo da população brasileira. Ou seja, independente dos projetos acerca dos caminhos que o país deveria ou não seguir, existia quase uma convergência quanto ao entendimento que o brasileiro era fraco, dono de um corpo pouco disciplinado para o trabalho e para a guerra" ${ }^{147}$.

"A herança deixada por uma sociedade escravocrata de desprezo pelo trabalho, entre outros fatores, obrigava o Estado e os empresários a atuarem no sentido de disciplinar as classes populares para o trabalho" ${ }^{148}$.

As atletas praticantes de volêi, tênis e a natação tinham destaques nos jornais esportivos, pois essas atividades eram consideradas ideais para o fortalecimento físico e mental das geradoras de novos cidadãos. A grande atleta durante o período estadonovista nos esportes femininos foi a nadadora Maria Lenk, figura destacada na propaganda do regime para enaltecer seus principios básicos.

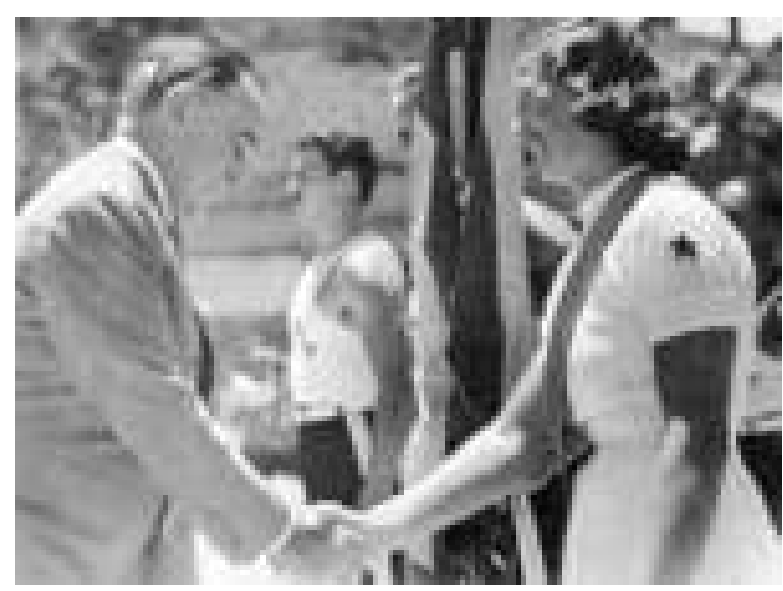

Maria Lenk, nadadora da seleção brasileira, recebe os cumprimentos de Getúlio Vargas, presidente da República do Brasil, pela quebra do recorde mundial nas provas dos 200 e $400 \mathrm{~m}$ nado peito, válida pelo Torneio Sul-americano de 1939. Foto retirada em 05 de janeiro de 1940, pela Agência Gazeta Press, disponível pelo site http://www.gazetapress.com.br/pautas/lista/11552/maria_lenk.

Para criar filhos fortes e sadios, afim com a ideologia eugenista, era necessário preservar o corpo das mulheres, pois essas detinham a responsabilidade de formar os cidadãos da nação. Assim, a prática esportiva era permitida às mulheres, mas o futebol

\footnotetext{
${ }^{147}$ Idem. Ibidem. p. 129.

${ }^{148}$ Idem. Ibidem. p. 182.
} 
era inaceitável, conforme dados seguintes.

Outras ações governamentais para concretizar seus projetos foram realizadas de forma mais direta no futebol brasileiro, por meio de regulamentações, normas e decretos, conforme apresentado na introdução da dissertação. Nesse enquadramento, além do afastamento obrigatório de elementos do Eixo nos clubes e federações, houve intervenções policiais dentro de campo, estruturação de legislações esportiva e trabalhista e censuras impostas pelo DIP.

Como exemplos dessas normatizações destacam-se a regulamentação formulada pelo DIP, em fevereiro de 1940, à Confederação Brasileira de Rádio e Difusão e à Federação Paulista das Sociedades de Rádio para irradiações esportivas, que proibiu se depreciar a atuação do árbitro e da polícia (representantes da ordem) e apreciações não amistosas aos times das nações estrangeiras.

Anteriormente a edição dessa lei, o próprio Vargas admitiu em 2 de fevereiro de 1937 em suas confidências escritas no diário, ter apreendido a edição do jornal $A$ Nota por constar nessa uma notícia agressiva à Argentina, após o jogo de futebol entre as seleções do Brasil e da Argentina, disputado em Buenos Aires ${ }^{149}$.

Ao futebol caberia a função de realizar uma propaganda positiva do Brasil no exterior. Os jogadores brasileiros deveriam se comportar como verdadeiros cavalheiros, respeitando os adversários e atuando com disciplina, harmonia e coletividade, assim como agia toda a nossa sociedade, pelo menos no ideal nacional formulado pelo governo.

Se na realidade as coisas se processavam de maneira diferente àquela projetada pelo governo, como ocorreu entre brasileiros e argentinos no jogo disputado em Buenos Aires, caberia ao Estado assegurar que a massa não fosse influenciada de modo ${ }^{149}$ VARGAS, Getúlio. Diário. Vol. II. São Paulo/ Rio de Janeiro: Siciliano/ Fundação Getúlio Vargas, 1995. p. 18. 
equivocado mesmo se, no limite, fosse necessário censurar ou suspender a edição de um jornal.

Para o governo, o futebol deveria proporcionar momentos de afirmação nacional afins com seus ideais de nação. Assim, compreende-se porque o confronto entre brasileiros e argentinos, em Buenos Aires, durante o Campeonato Sul-americano de 1936-37 tornou-se um motivo de preocupação.

Como escreveu Vargas em seu diário, foram divulgadas várias notícias exaltadas e hostis à nação argentina após o jogo, o que obrigou o Estado brasileiro a tentar remediar a situação mesmo porque, naquele no momento, existia uma outra questão delicada entre os dois países amigos: a questão do trigo que estava sendo tratada na Câmara ${ }^{150}$.

Outro modo de controle social presente no período estadonovista realizou-se por meio da ideologia trabalhista, pois essa igualmente se norteva pelos princípios caros ao regime, sendo outro elemento responsável pela domesticação social. Desse modo, o governo estadonovista trabalhou em duas frentes antitéticas, mas de grande amplitude social, para concretizar seus planos: o trabalho e o futebol, sendo esse último tido como esporte e lazer.

O imbricamento entre a ideologia trabalhista e a prática futebolista ampliaram a influência do governo na sociedade, sendo sintomático o fato de a seção esportiva de um dos jornais de maior circulação da época, o carioca Jornal do Comércio, ser na mesma página da seção sindical.

Reforçando esse raciocínio, puderam-se notar na introdução da dissertação as constantes regulamentações realizadas pelo governo para afinar a prática futebolista e

\footnotetext{
${ }^{150}$ VARGAS, loc. cit. O conflito que se instaurou entre as duas nações após a partida foi igualmente analisado por Plínio Negreiros, em sua tese de doutorado: NEGREIROS, Plínio José Labriola de Campos. Op. cit., p. 25.
} 
trabalhista aos seus ideais e a vinculação de figuras políticas a esses dois elementos como forma de ampliar a capacidade do futebol e da ideologia trabalhista em moldar a nação de acordo com os desejos do Estado Novo.

Conforme analisado anteriormente, a promulgação da CLT e a divulgação do salário mínimo compreendidos como elementos outorgados pelo grande herói da nação e não como direitos conquistados pela luta entre as diferentes classes sociais, confirmam o projeto governamental em projetar uma nação unida e harmônica, onde existiria apenas cooperação entre os atores sociais, jamais considerados como diferentes classes sociais.

Completaram esse quadro de bem estar social para os trabalhadores as constantes divulgações das realizações estadonovistas em favor desses, amplamente divulgados pela propaganda do regime nos periódicos e rádios. O fato de o herói nacional falar diretamente aos trabalhadores cotidianamente no programa radiofônico Hora do Brasil sugere uma ação governamental para estreitar os laços com a multidão por meio da ideologia trabalhista:

\begin{abstract}
"Desde 1934, Vargas criara um programa oficial — inicialmente a "Voz do Brasil" e, em seguida, "Hora do Brasil” —, no qual se transmitia uma programação centrada nas "realizações políticas” de seu governo. Porém, a partir da posse do ministro do Trabalho, Indústria e Comércio, Alexandre Marcondes Filho, em janeiro de 1942, esse programa passou a irradiar, semanalmente, uma palestra do próprio ministro, na qual ele se dirigia coloquialmente aos trabalhadores. "Falando aos trabalhadores brasileiros" tinha como objetivo básico divulgar a grande obra trabalhista do presidente, explicando aos diretamente interessados seus novos direitos. Devia ser um canal de comunicação privilegiado, rápido e sem intermediários, entre o povo e o presidente/Estado" ${ }^{151}$.
\end{abstract}

A grande divulgação realizada pelo rádio e pela mídia impressa aos eventos futebolistas e trabalhistas demonstram a importância dada pelo governo estadonovista a esses dois fatores sociais, conforme ressalvou Sevcenko:

${ }^{151}$ GOMES, Ângela de Castro. “Ideologia e trabalho no Estado Novo”. IN: PANDOLFI, Dulce (Org.). Op. cit., pp. 64-65. 
“Os dois rituais básicos da nova ordem eram o discurso presidencial de $1^{\circ}$ de maio no Estádio de São Januário e o noticiário diário da Voz do Brasil, ambos assentados sobre esse mesmo nexo simbólico, a voz dramatizante de Vargas, irradiada, recebida e incorporada como expressão do animus profundo da nação. Ademais, o envolvimento da imagem do presidente com o cinema, o teatro, o disco, o humor gráfico, o Carnaval e a gravura popular revela que a prática inédita de produzir o consenso por meio de apelos sensoriais e conotações afetivas, se mostrava muito mais eficiente que a racionalidade dos discursos" ${ }^{\prime 52}$.

Inicialmente, as rádios eram utilizadas apenas para transmitir comerciais até ocorrerem melhorias técnicas que possibilitaram aos regimes populistas a utilização desse veículo de informação para transformar a massa amorfa de ouvintes em força política $^{153}$. Sobre o início do rádio no Brasil, Sevcenko escreveu:

\begin{abstract}
"Sua introdução aqui só se deu no início dos anos 20, mas tantos eram seus problemas técnicos de transmissão, difusão, qualidade de sinal e programação, que só a partir dos anos 30 é que ele teria um impacto decisivo para a transformação da cultura brasileira. A idéia inicial era fazer dele uma espécie de teatro burguês irradiado, com músicas clássicas, leituras de longos trechos literários, recitação poética e discursos intermináveis. Portanto, a forma era precária e o conteúdo tedioso” ${ }^{\text {154 }}$.
\end{abstract}

A utilização do rádio foi objeto de discussão durante os anos 30 do século

XX. Alguns defendiam o projeto de radiodifusão educativa com finalidade de formar uma consciência nacional considerada fundamental à integração nacional. Outro grupo era favorável à perspectiva empresarial do rádio voltando-o para o consumo ${ }^{155}$.

Nesse período, o rádio adquiriu grande prestígio graças à diversificação das suas irradiações que abrangia de noticiários a transmissões esportivas ${ }^{156}$. Assim, o rádio tornou-se um dos principais divulgadores de peças publicitárias, fator que motivou os donos de jornais e revistas a comprarem as concessões de radiodifusão. Esse processo fez desaparecer os rádios clubes com característica amadora, tornando-

\footnotetext{
${ }^{152}$ SEVCENKO, Nicolau. Op. cit., p. 37.

${ }^{153}$ Idem. Ibidem. p. 587.

${ }^{154}$ SEVCENKO, Nicolau. loc cit.

155 CAPELATO, Maria Helena. "Propaganda política e controle dos meios de comunicação". IN: PANDOLFI, Dulce (Org.). Op. cit., p. 176.

156 Capelato exemplificou da seguinte forma o sucesso do rádio na década de 30, do século XX: “Em 1937, havia 63 estações, número que passou para 111 em 1945; o número de radiorreceptores aumentou de 357.921 aparelhos para 659.762 em 1942”. loc. cit.
} 
os empresas que, por diversas vezes, eram incorporadas pelos mesmos grupos políticos

e econômicos que controlavam os meios impressos ${ }^{157}$.

O primeiro conglomerado brasileiro de comunicação de massa foi construído

por Assis Chateaubriand, a Emissoras e Diários Associados. Sua composição foi

descrita por Othon Jambeiro da seguinte forma:

\begin{abstract}
"Iniciado com a posse de cinco emissoras de rádio, 12 jornais diários e uma revista, o império chegou ao auge 20 anos depois, em 1958, então contabilizando 36 emissoras de rádio, 34 jornais diários, 18 emissoras de televisão e várias revistas, entre as quais a de maior circulação do país, O Cruzeiro, com quase um milhão de exemplares vendidos semanalmente" 158 .
\end{abstract}

Durante o Estado Novo, a principal função do rádio era divulgar a

propaganda política do regime mas, em um segundo plano, esse meio de comunicação

se voltou ao consumo de produtos e ideias:

“O projeto político estado-novista de transformar o rádio num instrumento de educação e cultura com vistas à integração nacional teve em Roquette Pinto um de seus principais defensores. Fernando Limongeli Gurgueira (1995) analisou o significado político do projeto pedagógico e seu embate com outros projetos para o rádio ligados à esfera comercial. Ele mostra que, dentro do Estado Novo, havia duas propostas distintas para o rádio: uma do DIP, que previa a utilização maciça do rádio como veículo de propaganda do regime; e outra do Ministério de Educação e Saúde (o órgão encampou as idéias de Roquette Pinto), que restringia o uso do rádio às esferas de educação e cultura, opondo-se ao uso exclusivo do rádio para propaganda política. Do conflito entre os diferentes projetos resultou a definição do sistema de radiodifusão brasileira: um sistema misto em que o Estado controlava e fiscalizava a atividade, mas a exploração ficava por conta da iniciativa privada.

O projeto de “integração nacional pelas ondas” permitiu que as idéias e as mercadorias fossem “vendidas” num mesmo pacote; assim, não se pode concluir que o rádio, no Estado Novo, se restringiu ao papel de formação do consenso político, nem que seu controle tenha sido tão rígido" ${ }^{159}$.

O controle da radiodifusão brasileira durante o Estado Novo ocorria de duas

maneiras distintas, a saber: previamente, pela concessão de emissoras e equipamentos

e, posteriormente, por meio do controle da informação realizado pelos censores

157 JAMBEIRO, Othon (Org). Tempos de Vargas: o rádio e o controle da informação. Salvador: EDUFBA, 2004. p. 18.

${ }^{158}$ loc. cit.

${ }^{159}$ JAMBEIRO, Othon (Org). Op. cit., pp. 176-177. 
presentes nas emissoras:

"O controle da radiodifusão pelo Estado Novo ocorria de duas formas principais: a) exercido parcialmente através da concessão de emissoras de rádio e de licença para importação de equipamentos; e b) diretamente, exercido pelo DIP, através da censura e da distribuição da propaganda estatal” ${ }^{160}$.

A função do rádio, o maior veículo de comunicação do período, era divulgar

um Brasil unido geograficamente, politicamente e linguisticamente:

"Partindo cada um de seu isolamento real se encontram todos nesse território etéreo, nessa dimensão eletromagnética, nessa voz sem corpo que sussurra suave vindo de um aparato elétrico no recanto íntimo do lar, repousando sobre uma toalhinha de renda caprichosamente bordada e ecoando no fundo da alma dos ouvintes, milhares, milhões, por toda a parte e todos anônimos” 161 .

A Rádio Nacional, órgão oficial do regime estadonovista, foi incorporada à União pelo Decreto Lei $\mathrm{n}^{\circ}$ 2073, em 8 de março de 1940, como forma de pagamento dos impostos atrasados pela Companhia Estrado de Ferro São Paulo - Rio Grande, sua antiga proprietária. Por ser irradiada em todo o país, a principal função da Rádio Nacional era promover a integração nacional. Para realizar tal missão, uma expressiva verba oficial era utilizada pela Rádio Nacional para firmar a sua popularização com a contratação dos melhores músicos, cantores, radialistas, humoristas e técnicos da época ${ }^{162}$.

Outra emissora oficial do governo estadonovista era a “emissora trabalho”. A Rádio Mauá encontrava-se subordinada diretamente ao Ministério do Trabalho e era constantemente utilizada para divulgar a imagem de Vargas como o benfeitor da classe trabalhadora $^{163}$.

No mesmo período, a Confereração Brasileira de Rádio (fundada em 1933)

\footnotetext{
${ }^{160}$ Idem. Ibidem. p. 21.

${ }^{161}$ SEVCENKO, Nicolau. Op. cit., p. 585.

162 JAMBEIRO, Othon (Org). Op. cit., pp. 109-110.

${ }^{163}$ Idem. Ibidem. p. 112.
} 
regulava as rádios cariocas e as localizadas nos demais estados da federação e a Associação das Emissoras de São Paulo, presidida por Roquette Pinto, representava as rádios paulistas ${ }^{164}$.

As emissoras Byington ${ }^{165}$, conveniadas com a Gazeta Esportiva, tinham exclusividade nas transmissões de futebol, pois forneciam material de iluminação nos estádios a preço de custo em troca da autorização dos clubes para irradiar os jogos ${ }^{166}$. Sobre a primeira irradiação futebolistica, Fábio Franzini escreveu:

"De acordo com a historiografia sobre o rádio no Brasil, a primeira irradiação de um jogo de futebol no Brasil, a primeira irradiação de um jogo de futebol no país coube ao speaker (locutor) Nicolau Tuma, que em 19 de julho de 1931 narrou para os microfones da Rádio Educadora Paulista a partida entre as seleções de São Paulo e do Paraná, disputada no campo da Floresta, em São Paulo. No entanto, a leitura dos jornais do início dos anos 1930 indica que as emoções da bola já viajavam no ar antes dessa narração de Tuma”167.

Durante o mundial de futebol de 1938, Gagliano Neto narrou os cinco jogos disputados pelo selecionado brasileiro direto da França para a cadeia de rádios Byington associada aos jornais O Globo e Jornal dos Sports, com patrocínio do Cassino da Urca. O uso da imaginação do locutor esportivo foi uma das principais ferramentas para consolidar o rádio como veículo de comunicação entre os torcedores, conforme escreveu José Carlos Marques:

"No início, não havia cabines de imprensa nos estádios, os locutores narravam do meio da arquibancada, entre os torcedores. A partir de 1932, as rádios passaram a vender espaços publicitários e inicia-se a guerra de audiência - daí a valorização do relato imagético como fonte de se ganhar a preferência dos ouvintes. Além disso, o linguajar diferente do comunicador esportivo tem como motivos a necessidade de fugir ao comum, de modo a imprimir à expressão verbal um significado conotativo, e a luta pela conquista de maior audiência” ${ }^{168}$.

\footnotetext{
164 As rádios paulistas Difusora e Record impediam em sua frequência a transmissão da carioca Rádio Nacional entre as décadas de 30 a 50, do século XX. MELO e SOUZA, José Inácio. Op. cit., p. 51.

${ }^{165}$ Essa rede emissora era formada pelas rádios Clube do Brasil, Cruzeiro do Sul, do Rio de Janeiro, Cosmos e Cruzeiro do Sul, de São Paulo.

166 SOARES, Edileuza. A bola no ar. O rádio esportivo em São Paulo. São Paulo: Summus, 1994. p. 40.

${ }^{167}$ FRANZINI, Fábio. Corações da ponta da chuteira: capítulos iniciais da história do futebol brasileiro (1919 - 1938). Rio de Janeiro: DP\&A, 2003. p. 56.

168 MARQUES, José Carlos. O futebol em Nelson Rodrigues. O óbvio ululante, o Sobrenatural de
} 
Forte concorrente das emissoras Byington, a Rádio Record era muito popular em São Paulo por ter apoiado esse estado na revolta constitucionalista, ficando conhecida como “A voz de São Paulo” ${ }^{169}$. Porém, a exclusividade nas irradiações futebolisticas tidas pela primeira, somente acabou com a inauguração do Pacaembu, onde a cabine ficava aberta para todas emissoras de rádio (no Palestra e no Parque São Jorge o monopólio nas transmissões da Cosmos e da Cruzeiro do Sul, associadas Byington, continuou vigente) $)^{170}$.

\footnotetext{
Almeida e outros temas. São Paulo: Educ/ Fapesp, 2000. p. 90.

${ }^{169}$ SOARES, Edileuza. Op. cit., p. 37.

${ }^{170}$ Idem. Ibidem. p. 43.
} 


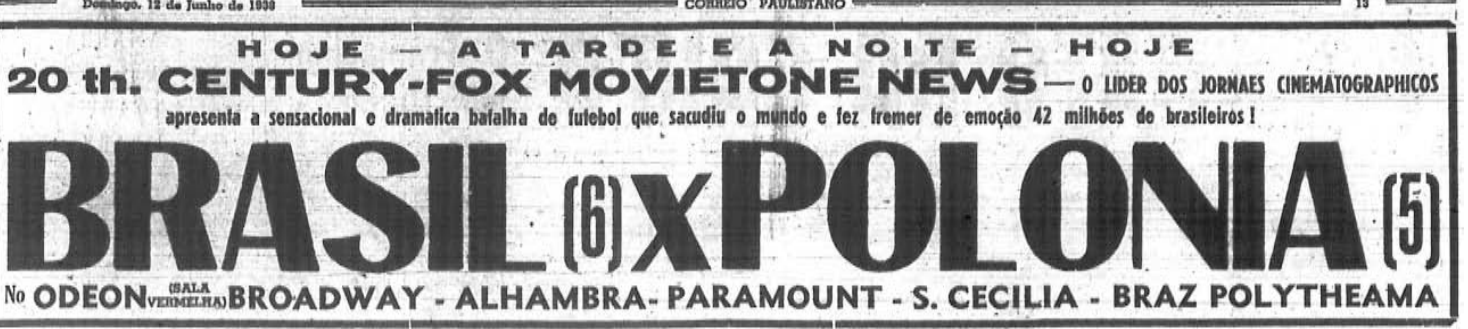

CINEMA NACIONAL

PALAVRAS DE GARMEN SANTOS SOBRE SEU PROXIMO FILME
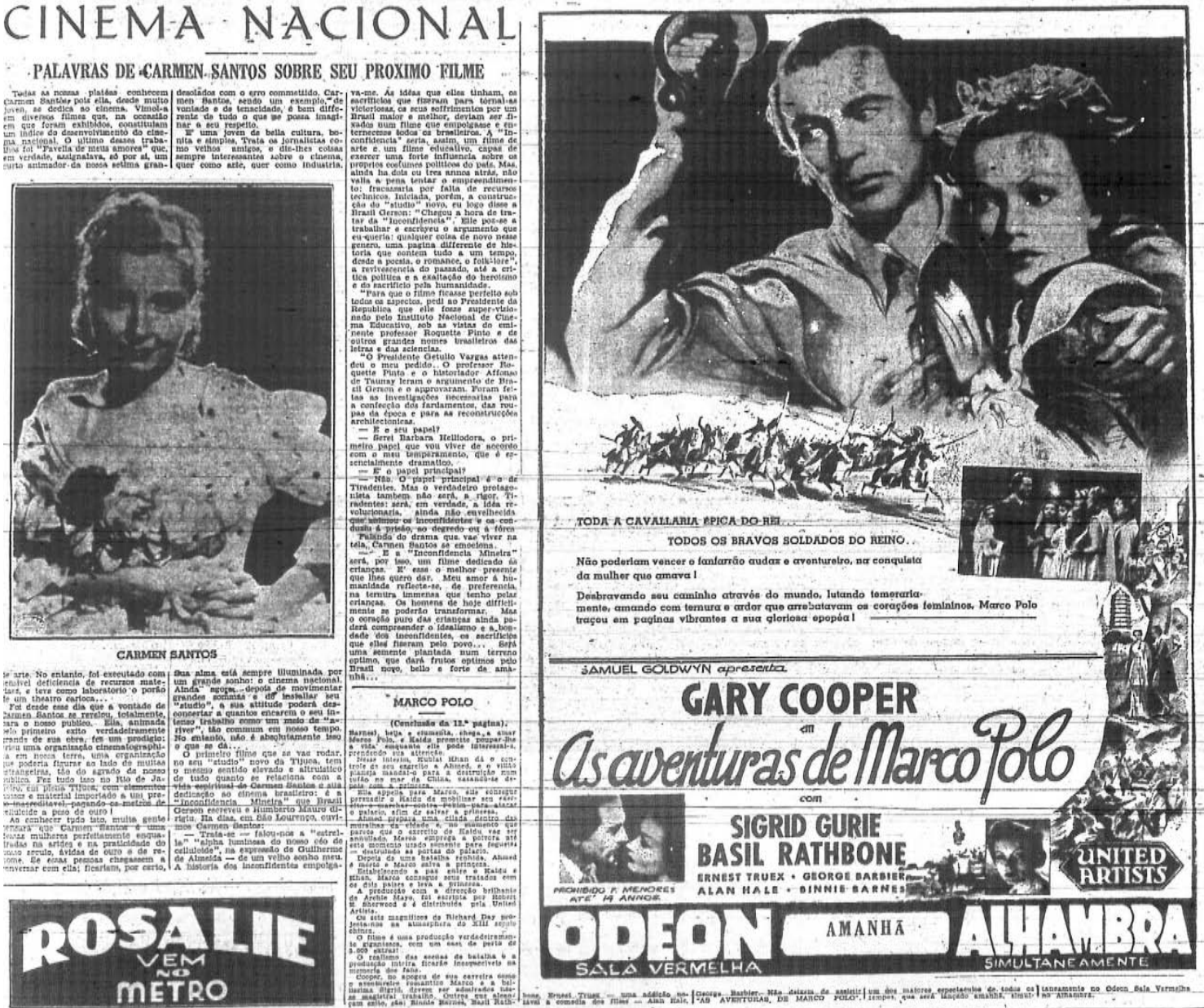

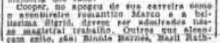

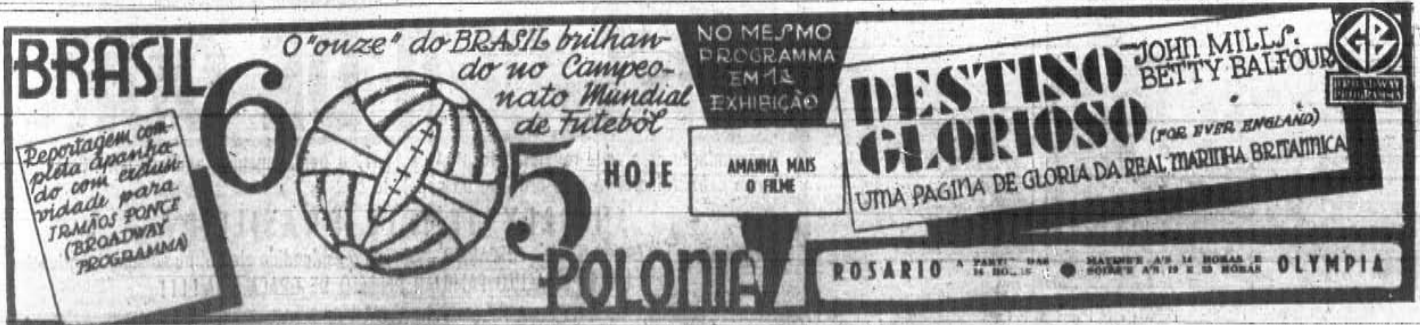

Chamada para a transmissão nos cinemas de um filme-reportagem do primeiro jogo disputado pelo Brasil contra a Polônia, no Mundial de Futebol de 1938. Imagem retirada do Correio Paulistano, 12 de junho de 1938, p. 13. De acordo com Negreiros, essa transmissão foi prometida para o dia 11 de junho de 1938, mas como o avião que traria as fitas para São Paulo não pode decolar devido o mau tempo, ela foi confirmada para o dia 12 de junho, em duas salas de projeção. NEGREIROS, Plínio José Labriola de Campos. A nação entra em campo: Futebol nos anos 30 e 40 . Tese de Doutorado História/ PUC-SP. São Paulo, 1998. p. 303. 
Durante a Copa do Mundo de Futebol disputada em 1938, além do rádio e dos periódicos, o torcedor contava com os filmes-reportagens para acompanhar os jogos brasileiros. As distribuidoras dessas imagens sabiam da ansiedade do torcedor em ver, mesmo que após os jogos, as imagens das partidas que eles acompanharam por rádio e vivenciaram nas páginas dos jornais. Assim, essas distribuidoras competiam entre elas para montar e trazer as fitas com maior tempo de duração no menor prazo possível ${ }^{171}$.

Baseado na profissionalização e na expansão do rádio como meio de comunicação de massa, símbolo da unificação nacional querida pelo governo, o futebol profissional se concretizou como espetáculo. Capaz de atingir multidões de aficcionados ele se tornou um instrumento para analisar a vida social do período:

\begin{abstract}
“As competições são espetáculos públicos e quem a eles acorre vai atraído pelo desejo de compor um ato coletivo. E, no entanto, o nexo do torcedor com a ação coletiva só ocorre quando seu corpo reflete no público resultado dos sentimentos, emoções, frustrações e inquietações da sua vida pessoal. Daí a simbologia associada a determinadas atletas e equipes e as razões obscuras que levam as pessoas a torcer uns pelos outros. Daí o mesmo modo pelo qual o esporte atua como um termômetro e um termostato da vida social” ${ }^{172}$.
\end{abstract}

De acordo com Gustave Le Bon, uma multidão não seria apenas o somatório de inúmeros indivíduos, mas um organismo independente, com vontade e identidade própria. A multidão pode realizar atos impensáveis de serem feitos individualmente. Quanto mais homogênea for a massa, mais dependentes seriam os indivíduos formadores da sentença do próprio grupo, e mais alheios às opniões externas ${ }^{173}$.

Assim, na embrionária indústria cultural do período estadonovista, cujo alicerce era o rádio, a presença de uma massa torcedora e trabalhadora para ser constantemente articulada aos ideais do governo constituiu-se como uma importante base de apoio a ser conquistada para a efetivação dos projetos governamentais.

\footnotetext{
${ }^{171}$ NEGREIROS, Plínio José Labriola de Campos. Op. cit., p. 302.

${ }^{172}$ SEVCENKO, Nicolau. Op. cit., p. 579.

173 apud SUROWIECKI, James. A sabedoria das multidões. Rio de Janeiro: Record, 2006. p. 14.
} 
Nesse sentido, constitui-se sintomático o fato de serem encontrados tantos torcedores de futebol do carioca Clube de Regatas Flamengo nas regiões norte e nordeste de país. Como os demais territórios brasileiros distantes do circuito Rio de Janeiro - São Paulo recebiam apenas a irradiação da Rádio Nacional localizada no capital fluminense, as transmissões radiofônicas dos jogos de futebol que essas regiões tinham acesso eram dos jogos realizados pelo campeonato carioca.

Esse fato constitui um exemplo de como o Estado Novo fortaleceu seus ideais quando os vinculou à ideologia trabalhista e ao esporte de maior influência no país com as transmissões via rádio. Auxiliado pela propaganda divulgada em grande escala, própria da embrionária cultura de massa, o governo transmitiu seus valores aos indivíduos tanto em seus momentos de trabalho, como nos períodos de lazer, a fim de projetá-los como cidadãos da nação. 


\section{OS TRABALHADORES DA BOLA}

\subsection{Padronização de Heróis}

O futebol não se encontra descolado da sociedade, ao contrário, interage dialeticamente nessa. Assim, a burocratização, o autoritarismo e a censura imposta pelo regime na sociedade encontraram no futebol um outro ambiente para se constituir.

Conforme teorizou Roberto DaMatta, a política se constrói mediante cerimoniais ritualizados cotidianamente nas sociedades. Assim, elementos dramáticos como futebol, o carnaval e as procissões religiosas são extremamente importantes para a concretização de determinados governos e projetos políticos ${ }^{174}$.

De acordo com o autor, um rito nacional seria toda ocasião capaz de catalizar a atenção e alterar radicalmente a normalidade das atividades sociais. Normalmente, nessas ocasiões ocorre um abandono do trabalho, fato denominado "feriados nacionais" 175

Esses rituais nacionais podem ser compreendidos pela temporalidade em que são processados. Os rituais burocráticos estariam ligados ao tempo histórico, enquanto os rituais gregários ocorreriam no tempo cósmico ${ }^{176}$. Como exemplo dessas categorias ritualísticas, DaMatta destacou a cerimônia do Dia da Pátria como ritual burocrático, o Carnaval como exemplo de ritual gregário e as procissões religiosas como rituais mistos.

A característica principal dos rituais burocráticos seria a unidade e a uniformização do coletivo que torna todos os homens iguais em suas posições, conforme salientou DaMatta ao analisar o Dia da Pátria:

\footnotetext{
${ }^{174}$ DAMATTA. Roberto. Op. cit., p. 27.

${ }^{175}$ Idem. Ibidem. p. 36.

${ }^{176}$ Idem. Ibidem. p. 43.
} 
"O desfile militar cria um sentido de unidade, sendo o seu ponto crítico a dramatização da idéia de corporação nos gestos, vestes e verbalizações que são sempre idênticos. No Dia da Pátria, assim, ficam separados autoridades e povo e, dentre as autoridades, aqueles que detêm e controlam maior ou menor parcela de poder" ${ }^{177}$.

"As fardas simbolizam identidades sociais concretas e operam em todos os níveis da vida social. Um coronel fardado não deixa de ser coronel quando não está fardado - apenas pode perder ou provocar a perda de consciência de sua posição" ${ }^{178}$.

Já a força de ordenação social dos rituais comunitários consistiria em seu poder

de agregar diferentes e hierarquizados setores sociais:

“Numa palavra, a communitas do Carnaval é uma função da rígida posição social dos grupos e segmentos nela implicados no mundo quotidiano. Sua universalidade e homogeneidade servem precisamente para reforçar e compensar, num outro plano, o particularismo, a hierarquia e a desigualdade do mundo da vida diária brasileira” ${ }^{179}$.

Nos rituais mistos como as procissões religiosas, estaria presente a

hierarquização dos ritos burocráticos e a participação de diferentes setores sociais, como

nos ritos gregários:

"Tais ritos em geral são iniciados com uma missa, estão centrados na procissão (onde a imagem do santo sai de um santuário para outro) e terminam com uma festa no adro da Igreja, onde foi depositada a imagem. Aí se vendem doces, bebidas e são leiloados objetos para a irmandade dos santo, há jogos e danças, criando-se um ambiente de encontro e comunhão muito semelhante ao Carnaval. Além disso, a própria procissão teria características conciliadoras, pois seu núcleo é formado por das pessoas que carregam a imagem dos santos, e tais pessoas estão hierarquizadas: são as autoridades eclesiásticas, civis e militares. Entretanto, o núcleo é formado e seguido por um conjunto desordenado de todos os tipos sociais: penitentes que pagam promessas, aleijados que buscam alívio para seus males, homens normais que apenas demonstram sua devoção ao santo. A procissão, como conseqüência, reúne os componentes da hierarquização da parada militar no seu centro e os elementos da reunião polissêmica no seu conjunto" 180 .

Seguindo o raciocínio formulado por DaMatta, o estudo caracterizou o futebol

como um ritual misto, similar às procissões religiosas, pois existem inúmeras semelhanças entre futebol e certas formas religiosas, essas últimas compreendidas como um sistema composto de mitos, dogmas, ritos e cerimônias, conforme teorizou

\footnotetext{
${ }^{177}$ Idem. Ibidem. p. 45 e 47.

${ }^{178}$ Idem. Ibidem. p. 47.

${ }^{179}$ Idem. Ibidem. p. 51.

${ }^{180}$ loc. cit.
} 
Durkheim $^{181}$.

A presença dos mitos futebolísticos pode ser exemplificada pela transcendencialidade da fama de grandes jogadores como Pelé; os dogmas da religião futebol seriam as regras do jogo e sua hierarquização em entidades e cargos; o rito consiste na própria partida de futebol, cheia de significados para seus participantes e os torneios seriam as cerimônias futebolistícas, pois se constituem de elemento capaz de mobilizar os participantes do ritual para celebrar o deus clubístico ${ }^{182}$.

Outro motivo que levou a perceber o futebol como um ritual burocrático e comunitário ao mesmo tempo, consiste no fato de elementos rígidos e hierarquizados em sua estrutura (como as regras, ordenação dos clubes e entidades, esquemas táticos e uniformização dentro de campo) conviverem com seu poder de agregar diferentes setores sociais em sua prática e vivência cotidiana (proporcionando, inclusive, a ascensão social de jogadores pobres, negros e mestiços) ${ }^{183}$.

Nesse sentido, o estudo se afasta da concepção ritualística conceituada por Franco Junior em sua análise sobre o futebol, para o qual a ordenação do jogo se daria através, e apenas, por seu aspecto religioso. Esse conceito baseia-se em algumas características presentes no jogo de futebol, a saber: o sistema de gestualidades e sonoridades significantes para seus envolvidos, os símbolos presentes na composição

\footnotetext{
${ }^{181}$ Os fenômenos religiosos foram classificados pelo sociólogo francês em duas categorias fundamentais: as crenças, que como estados de opinião consistem em representações, e o rito, entendido como um modo de ação determinado. DURKHEIM, Emile. Op. cit., pp. 18-19.

${ }^{182}$ Hilário Franco Junior analisou com profundidade o futebol como metáfora religiosa, em principal os conceitos de ídolos, divindades, ritos, símbolos e dogmas. FRANCO JUNIOR, Hilário. Op. cit., cap. 7.

${ }^{183}$ Pode-se enquadrar o processo de ascensão social proporcionada pelo futebol às classes desfavorecidas socialmente ao que Roberto DaMatta denominou como "ritual de reforço". Nesse tipo de ritualização, o simbólico fica separado do real, pois o primeiro se reforça perante a realidade, criando um respeito pela imagem. Desse modo, compreende-se a adoração projetada sobre a figura de Leônidas da Silva, futebolista considerado como herói nacional, a despeito de ser negro e proveniente dos setores subalternos da sociedade. DAMATTA. Roberto. Op. cit., p. 62.
} 
dos campos oficiais e da própria bola com que ele é jogado, o fato de ele ocorrer sempre em locais específicos (preferencialmente nos estádios, os santuários da bola), a presença da regras como dogmas religiosos e a existência de oficiantes, assistentes e fiéis:

\footnotetext{
"Se o jogo futebol é religião e cada clube divindade, toda partida é rito, como indica a própria origem da palavra, vinda do sânscrito rita, 'ordem', 'regra', 'ritmo', isto é, conjunto de atos repetitivos que se supõe estabelecer ou recuperar certa ordenação cósmica ou humana” ${ }^{184}$.
}

Assim, reforçando o caráter misto do ritual futebolístico, durante o Estado Novo procurou-se firmar a imagem do futebol como parada militar, pois cabia a esse esporte disciplinar, uniformizar e educar a massa para o trabalho e demais interesses projetados pelo governo como nacionais. Em um regime autoritário e hierarquizado como o presente no período, era fundamental naturalizar ao máximo o fato de grupos específicos regerem os rumos nacionais em favor de seus interesses.

Como exemplo dessa imagem militarizada do futebol em que a concepção festiva da partida era solapada pela cerimônia burocrática em prol da unidade do grupo, destaca-se a notícia publicada pelo Correio Paulistano que criticou o aspecto lúdico presente no segundo tempo do jogo entre Corinthians e Botafogo, válido pelo Torneio Rio-São Paulo ${ }^{185}$.

O time paulista construiu o resultado durante o primeiro período da partida com dois gols de diferença sobre o rival. Essa etapa inicial foi classificada pelo jornal como vistoso e movimentado, sendo um “dos melhores [períodos] visto nos últimos tempos” 186 .

\footnotetext{
${ }^{184}$ FRANCO JUNIOR, Hilário. Op. cit., p. 270.

${ }^{185}$ Jogo disputado em $1^{\circ}$ de novembro de 1942 , no Pacaembu. Notícia sobre a partida presente na edição do Correio Paulistano, 03 de novembro de 1942. Resultado da partida: 5x 4 para o Corinthians Paulista.

${ }^{186}$ loc. cit.
} 
Porém, no segundo tempo de jogo os corinthianos, tendo como certa a vitória (mesmo porque, o quarto gol do Botafogo só ocorreu aos quarenta e dois minutos da etapa complementar de jogo), abusaram das jogadas mais espetaculares, afins com a técnica e o talento individual dos jogadores.

Esse tipo de jogadas era a antítese do ideal de harmonia coletiva e burocratização social pregada pelo governo estadonovista. Nesse sentido, é possível compreender o comentário realizado pelo jornalista, porta-voz da ordem, quando escreveu que o segundo tempo do jogo não foi tão bom quanto o primeiro, pois os corinthianos “fizeram jogadas de arquibancada que, na maioria das vezes, deliciaram o seu público, mas em prejuízo do quadro” ${ }^{187}$.

A concepção de bom futebol implícita na reportagem fundamentava-se nos seguintes valores: seriedade, disciplina e coletividade. Nesse contexto, a escolha dos melhores jogadores da partida constitui-se sintomática, pois entre os três escolhidos, Hércules, Chico Preto e Santamaria, apenas o primeiro era atacante e tinha marcado gols.

Assim, percebe-se uma grande tensão ao analisar o descompasso presente entre a realidade futebolística, na qual imperava o individualismo e o jogo voltado ao espetáculo, e o discurso regularizador do jogo de bola, pensado pelo Estado Novo para concretizar seus ideais nacionais e ventilado por seus órgãos de comunicação.

Essa tensão estava presente na própria sociedade do período e refletia igualmente nos discursos dos intelectuais que nessa época se preocupavam em delimitar as especificidades de uma pretensa cultura brasileira. Esses ideólogos representavam os valores do regime estadonovista e das classes dominantes e auxiliaram na construção de

\footnotetext{
${ }^{187}$ loc. cit.
} 
uma noção de cultura brasileira ainda presente no imaginário social, ressaltando princípios como coletivismo, harmonia social e racial e o conservadorismo.

Um dos grandes pensadores da época foi o pernambucano Gilberto Freyre. Em sua tentativa de explicar a história brasileira pelo processo de miscigenação, a perspectiva conservadora de sua tese proveniente da sua origem social era notada pelo destaque da presença ibérica no processo de miscigenação, para o qual a valorização do negro ocorre na tentativa de incorporá-lo mais facilmente ao capitalismo brasileiro ${ }^{188}$.

Além disso, conforme ressalvou Dante Moreira Leite, na tese de miscigenação racial realizada por Gilberto Freyre, a presença do elemento negro somente era tolerada quando esse reconhecia e aceitava a sua situação de subordinação em relação a homem branco ibérco $^{189}$ :

\footnotetext{
"A obra de Gilberto Freyre revela uma profunda ternura pelo negro. Mas pelo negro escravo, aquele que 'conhecia a sua posição' - como o moleque da casa-grande, como o saco de pancadas do menino rico, como cozinheira, como ama de leite ou mucama da senhora moça. Nesses casos, o branco realmente não tinha preconceito contra o negro, podia até estimá-lo" ${ }^{190}$.

Em sintonia com os valores estadonovistas, a teoria de Freyre apresenta-se sem

a presença de conflito e tensão com o aspecto regional submetido ao âmbito nacional, conforme salientou Carlos Guilherme Mota:
}

\begin{abstract}
"Na verdade, ficam eliminadas, em seu discurso, as contradições reais do processo históricosocial, as classes e os estamentos em seus dinamismos específicos e seus conflitos e desajustamentos no sistema global. Do ponto de vista interpretativo-metodológico, o encaminhamento é hábil, de vez que opera sistematicamente com pares antagônicos para... esvaziar a contradição. Apesar de trabalhar com duas categorias sociais bem definidas - os senhores e os escravos - não são as classes ou as raças que comandam o processo: a tarefa, com frequência, não se desenvolve no sentido de precisar, de definir contornos sociais, mas de imprecisá-los, de matizar a regra geral em tantos exemplos quantos sejam necessários,
\end{abstract}

\footnotetext{
${ }^{188}$ MOTA, Carlos Guilherme. Ideologia da cultura brasileira (1933-1974). 4º ed. São Paulo: Ática, 1978. p. 61.

${ }^{189}$ Esse aspecto da miscigenação, que legitimou a sua difusão durante o Estado Novo, será melhor tratado quando analisada a figura de Leônidas da Silva, no próximo capítulo.

${ }^{190}$ LEITE, Dante Moreira. O caráter nacional brasileiro: história de uma ideologia. $4^{\text {a }}$ ed. São Paulo: Pioneira, 1983. p. 311.
} 
justamente para indefinir os contornos dos grupos sociais” ${ }^{191}$.

Outro importante idelógo do regime estadonovista foi Fernando de Azevedo, cuja presença em importantes cargos na área da educação contribuiu para propagar o seu conceito de cultura brasileira. Para o autor, a articulação entre cultura e educação deveria contribuir para propagar os seguintes valores do Estado Novo: aristocratismo, humanismo, ilustração e socialismo ${ }^{192}$.

Deve-se ressaltar que socialismo, de acordo com Fernando de Azevedo, compreendia a cooperação entre indústria, Estado e trabalhadores (que deveriam ser educados para profissão), ou seja, sintetizava o ideal de harmonia e cooperação entre as diferentes classes sociais ${ }^{193}$.

A “Escola Nova” proposta por Fernando de Azevedo tinha como missão divulgar os valores nacionais e coletivos à massa. Caberia a aristocracia ilustrada qualificar as classes populares para o trabalho e deixá-la apta para participar do processo político e cultural em curso durante o Estado Novo. Para o educador, o individualismo era nocivo à nação, pois levava a sociedade ao conflito e não à criação:

\footnotetext{
"Entre as características gerais indica ainda o individualismo, que não é individualismo criador, encontrável, por exemplo, entre os anglo-saxões; ao contrário, é muitas vezes negativo, pois é uma tendência anti-social de oposição do indivíduo à sociedade. Nesse sentido, embora conduza a 'sentimentos de audácia, coragem e altivez", alimenta igualmente a dispersão, a indisciplina e os conflitos “ ${ }^{194}$.

Em afinidade com os ideais estadonovistas esboçados acima, Mazzoni assegurava que os principais problemas do nosso futebol provinham da atividade individualistas dos dirigentes, voltadas apenas para benefício de seus próprios clubes.
}

\footnotetext{
${ }^{191}$ MOTA, Carlos Guilherme. Op. cit., p. 67.

${ }^{192}$ Idem. Ibidem. p. 76.

${ }^{193}$ Idem. Ibidem. p. 77.

${ }^{194}$ LEITE, Dante Moreira. Op. cit., p. 328-329.
} 
Assim, para o jornalista paulista qualquer tipo de separatismo, sejam individualismos, regionalismos ou clubismos, deveria ser solapado pela racionalização esportiva promovida pelo Estado Novo:

“O autor elenca um rol de críticas que vão desde a precariedade logística do futebol brasileiro, até os critérios adotados na confeccção das tabelas dos campeonatos, a indiscriminada importação de jogadores estrangeiros, muito comum na época, as dissidências entre associações e ligas, enfim, aspectos que, segundo ele, diziam respeito ao faccionismo pernecioso, descentralizador e anárquico no futebol, marcando aquilo que ele definia, genericamente, por clubismo.

Eram os interesses e paixões particulares, por clubes ou Estados da federação, que emperravam a consolidação institucional e técnica de um verdadeiro futebol nacional. Sob esse aspecto, Mazzoni faz uma ruidosa defesa dos ideais propagados pelo Estado Novo, legitimando todo o seu perfil centralizador, estendido ao âmbito esportivo" ${ }^{195}$.

A concepção burocrática de praticar o futebol, contraponto do aspecto festivo igualmente presente no ritual misto, acentuava o ideal estadonovista de constituir uma sociedade harmônica e disciplinada. Nesse sentido, Thomas Mazzoni prefere o jogo praticado em prol do conjunto, em detrimento ao futebol praticado com um exibicionismo individualista:

"Para Mazzoni, não era esse o caminho [do individualismo, do futebol praticado de modo exibicionista] e sim um jogo no qual todos estivessem solidários em torno de uma tática préestabelecida. De certa forma, Mazzoni buscava fazer uma analogia com os debates que se faziam no Brasil, principalmente após o golpe de 10 de novembro de 1937. Esse era o discurso que vinha do regime ditatorial: os esforços individuais devem estar a serviço da coletividade, da nação, a partir dos interesses nacionais. Dessa forma, não poderia haver espaço para os particularismos regionais, pois não importava o sucesso da região ou de uma atividade econômica, mas do progresso homogêneo do país, expressão recorrente na época” ${ }^{196}$.

Ainda citando Mazzoni, destaca-se a crítica realizada por ele ao

descompromisso, falta de seriedade e excesso de individualismo, presentes no primeiro

tempo de jogo entre Brasil e Polônia, válido pelo Mundial de Futebol de 1938:

“Chegou o dia da nossa primeira partida e minutos após iniciado o prélio, contra a Polônia, o público teve a certeza de que os brasileiro venceriam por 7 ou 8 gols... Superioridade absoluta. Mas, nosso quadro, sempre com a velha mania das brincadeiras facilitou tanto que o prélio terminou empatado! (...) a lição ficou... sem ser aproveitada pelos nossos jogadores, pois nos prélios seguintes fizeram o mesmo, gostavam mais de zombar dos adversários do que meter-

\footnotetext{
195 TOLEDO, Luíz Henrique de. op. cit., p. 184.

${ }^{196}$ NEGREIROS, Plínio José Labriola de Campos. Op. cit., p. 273.
} 
lhes o couro nas redes...” ${ }^{197}$.

Em consonância com esse discurso, para Mário Filho o individualismo seria um resquício da época do futebol amador e espelhava a valorização do individualismo na sociedade brasileira, entendido aqui como forma de distinção ${ }^{198}$. Nesse sentido, convergindo com os ideais nacionais estadonovistas, o jornalista carioca defendia o jogo coletivo como um dos trunfos do futebol brasileiro:

\begin{abstract}
"Unir-se, formar uma verdadeira equipe: nisso consistia a receita de Mário Filho para a superação da humildade e do individualismo mórbidos, que, de acordo com sua observções, perturbavam o sucesso do fuebol brasileiro" 199.
\end{abstract}

Em uma sociedade em que a ideologia estadonovista pregava o trabalho árduo como um meio para o indivíduo ascender socialmente e pertencer ao corpus social, a noção de um futebol burocratizado auxiliava na tarefa de formatar a sociedade nos moldes estadonovistas.

Essa concepção de futebol também estava presente na notícia publicada em 27 de fevereiro de 1940, no Jornal dos Sports:

\footnotetext{
“A peleja sempre foi desenhada dentro desse terreno de enthusiasmo louco dos nossos contra a qualidade do trabalho adversário. De um lado intelligencia, engenho e manha, do outro muito ardor, muita combatividade, sem contudo haver a necessária diretriz technica a guiar racionalmente os nossos jogadores” ${ }^{200}$.
}

Nessa notícia o jornalista exaltou as qualidades do time trabalhador, associando os disciplinados jogadores adversários a figuras inteligentes e merecedoras da vitória. Em contraposição, os jogadores brasileiros foram taxados como loucos e irracionais, pois não apresentaram um jogo padronizado no gramado.

\footnotetext{
${ }^{197}$ MAZZONI, Tomas. História do Futebol no Brasil. São Paulo: Edições Leia, 1950. p. 273.

${ }^{198}$ ANTUNES, Fátima Martin Rodrigues Ferreira. Op. cit., p. 125.

${ }^{199}$ Idem. Ibidem. p. 129.

${ }^{200}$ Matéria retirada do comentário sobre a quarta partida final da Copa Roca de 1939, disputada no Parque Antártica em 25 de fevereiro de 1940. O jogo acabou com o placar de três gols a zero para a Argentina.
} 
Sem usar a racionalidade e o rigor tático devidos, os brasileiros foram representados como anti-heróis da pátria, verdadeiros malandros descompromissados com a vitória e indignos de vencer a partida.

A tensão presente entre o discurso de um futebol individualista, anárquico e gingado versus a construção de um futebol coletivo, regido por esquemas táticos e praticado com harmonia e sem violência, encontrava-se na concepção de cultura brasileira projetada por Artur Ramos, durante o Estado Novo, para o qual o aspecto apolíneo, em oposição ao dionisíaco, era aceito e projetado como próprio de nossa sociedade ${ }^{201}$.

O conflito aqui presente entre a realidade social e os valores projetados pelo governo constitui-se elemento de longa duração histórica pois, desde o processo de colonização brasileira, este é perceptível nas palavras dos cronistas estrangeiros que caracterizavam os habitantes do país como indolentes, preguiçosos e aversos ao trabalho.

Em seu estudo sobre o início da formação da nação brasileira, o historiador Sérgio Buarque de Holanda escreveu em 1936 que as raízes dessas problemáticas características brasileiras surgiram em nosso processo colonizador realizado pelos portugueses $^{202}$.

Vale ressaltar que, apesar de a publicação desse texto ter ocorrido um ano antes da promulgação do Estado Novo, ele fez bastante sucesso durante o regime, pois refletia sobre os pontos considerados problemáticos pelo governo como a falta de coletividade, respeito pela hierarquia e disciplina social, indo buscar no passado colonizador suas

\footnotetext{
${ }^{201}$ MOTA, Carlos Guilherme. Op. cit., p. 88.

202 HOLANDA, Sérgio Buarque. Raízes do Brasil. 26º ed. São Paulo: Companhia das Letras, 1995. p. 3538. De acordo com Dante Moreira Leite, Sérgio Buarque procurou predizer com o estudo do passado colonial, o futuro da crise vivida no momento de sua publicação. LEITE, Dante Moreira. Op. cit., p. 318.
} 
causas e soluções.

O historiador iniciou o livro demarcando a anarquia e a indolência como características próprias dos países ibéricos e do Brasil:

“À frouxidão da estrutura social, à falta de hierarquia organizada devem-se alguns dos episódios mais singulares da história das nações hispânicas, incluindo-se nelas Portugal e o Brasil. Os elementos anárquicos sempre frutificaram aqui facilmente, com a cumplicidade ou a indolência displicente das instituições e costumes” ${ }^{203}$.

Essa nossa falta de compreensão hierárquica seria fruto da fluidez dos privilégios de nobreza na península ibérica e da importância conferida, pelos ibéricos, ao mérito individual. Sobre essa última característica, Sérgio Buarque praticamente previu o advento do Estado Novo e legitimou a necessidade de existirem governos mais centralizados em sociedades menos racionalizadas e disciplinadas:

\begin{abstract}
"Nas nações ibéricas, à falta dessa racionalização da vida, que tão cedo experimentaram algumas terras protestantes, o princípio unificador foi sempre representado pelos governos. Nelas predominou, incessantemente, o tipo de organização política artificialmente mantida por uma força exterior, que, nos tempos modernos, encontrou uma das suas formas características nas ditaduras militares” ${ }^{204}$.
\end{abstract}

A própria noção de malandragem foi esboçada por Sérgio Buarque quando ele tratou sobre a repulsa do homem ibérico pelo trabalho. Para ele, esse seria um dos pontos fulcrais da desorganização social brasileira, pois a inexistência de uma ética trabalhista auxiliaria a reduzir a capacidade de organização social o que, consequentemente, diminuiria a organização racional entre os homens e aumentaria a falta de coesão entre eles:

\footnotetext{
"Um fato que não pode deixar de tomar em consideração no exame da psicologia desses povos [ibéricos] é a incrível repulsa que sempre lhe inspirou toda moral fundada no culto ao trabalho (...) A ação sobre as coisas, sobre o universo material, implica submissão a um objeto exterior, aceitação de uma lei estranha ao indivíduo. Ela não é exigida por Deus, nada acrescenta à sua glória e não aumenta nossa própria dignidade. Pode-se dizer, ao contrário, que prejudica e a
}

\footnotetext{
${ }^{203}$ Idem. Ibidem. p. 33.

${ }^{204}$ Idem. Ibidem. p. 38.
} 
avilta” ${ }^{205}$.

Para Sérgio Buarque, as grandes empresas colonizadoras promovidas pelos

povos ibéricos fomentaram o espírito de aventura desses povos e demarcaram as

colônias como lugares propícios para aventureiros. Sobre a diferença ética entre o

trabalhador e o aventureiro, esse historiador escreveu:

\begin{abstract}
"Existe uma ética do trabalho, como existe uma ética da aventura. Assim o indivíduo do tipo trabalhador só atribuirá valor moral positivo às ações que sente ânimo de praticar e, inversamente, terá por imorais e detestáveis as qualidades próprias do aventureiro - audácia, imprevidência, irresponsabilidade, instabilidade, vagabudagem - tudo, enfim, quanto se relacione com a concepção espaçosa do mundo, característica desse tipo.

Por outro lado, as energias e esforços que se dirigem a uma recompensa imediata são enaltecidos pelos aventureiros; as energias que visem à estabilidade, à paz, à segurança pessoal e os esforços sem perspectiva de rápido proveito material passam, ao contrário, por viciosos e despresíveis para eles. Nada lhes parece mais estúpido e mesquinho do que o ideal do trabalhador" 206 .
\end{abstract}

Nessa concepção "espaçosa” de se apropriar do mundo realizada pelos aventureiros ibéricos, a grande lavoura de exploração e o emprego do trabalho escravo foram elementos fundamentais para concretizar o espírito malandro e a aversão pelo trabalho nas colônias ibéricas:

"O que o português vinha buscar era, sem dúvida, a riqueza que custa ousadia, não riqueza que custa trabalho. A mesma, em suma, que se tinha acostumado a alcançar na Índia com as especiarias e os metais preciosos" ${ }^{207}$.

Durante o Estado Novo, para diminir a presença da desordem, indisciplina, individualismo e descompromisso na sociedade brasileira, e concretizar os ideais

\footnotetext{
${ }^{205}$ loc. cit.

${ }^{206}$ Idem. Ibidem. p. 44.

${ }^{207}$ Idem. Ibidem. p. 49.
} 
nacionais formulados pelo governo, era fundamental combater esses elementos nocivos à sociedade e, nessa missão, o futebol foi amplamente utilizado.

Os jornais do período como narrativas da ordem que revelavam as diretrizes estadonovistas exaltavam o futebol praticado com disciplina, senso de coletividade e seriedade, conforme demonstrou a matéria publicada na Gazeta Esportiva intitulada “O artilheiro famoso da cidade: A revelação de 1940”. Nessa reportagem, com uma foto grande do jogador do Ipiranga, o jornal destacou Arnaldo Alves Garcia, o Peixe, artilheiro do Campeonato Paulista com vinte e um gols pelas seguintes qualidades:

\begin{abstract}
"Peixe é um dominador exímio da pelota. Seu estilo é simples e, portanto, produtivo. Não é nenhum espetáculo de técnica, de fintas primorosas, de 'bicicletas' ou de zigue-zagues. Não. Todo o seu valor está na produção, no rendimento, nas escaladas, nas infiltrações. Não quer jogar para o público. Prefere, isto sim, jogar para o quadro. Dono de uma elasticidade única, ele faz com que a vista do expectador vá dando saltos e mais saltos a cada investida cujo remate é sempre uma ameaça tremenda. Disciplinado, 'gentleman', não se molesta com ninguém e não sabe o que é ser molestado. Esquiva-se das entradas bruscas e poupa o adversário nesse tocante, preferindo castigá-lo com descidas vertiginosas, pondo em pânico o último redito contrário" 208 .
\end{abstract}

As qualidades futebolísticas destacadas no período seguiam os pontos considerados fundamentais pelo governo para construir a identidade nacional. Na reportagem, o jogador não foi exaltado pela quantidade de gols marcados. Seu estilo produtivo, o fato de jogar pensando no bem coletivo, com harmonia, disciplina, simplicidade e sem violência foram suas características mais destacadas.

A noção de coletivismo e a crença de ser a união um elemento fundamental para alcançar a meta estipulada, conforme destacado na notícia acima, foram exaltadas pelo governo em sua tentativa de criar uma identidade nacional brasileira, e pelos jornalistas esportivos como elementos constituintes da prática futebolística no Brasil.

Referindo-se ao popular jogador de futebol como "gentleman”, o jornalista elevou Peixe aos grandes esportistas do passado, provenientes dos setores cultos e ricos

${ }^{208}$ Gazeta Esportiva, 6 de maio de 194, p.3. 
da sociedade na época do futebol amador.

Essa era a ideia presente na imprensa esportiva da época. O futebol profissional poderia ser jogado por pessoas provenientes das classes populares, desde que essas se comportassem de acordo com os princípios elitistas do esporte e da ideologia estadonovista, conforme se verá mais adiante, na segunda parte do capítulo III.

O homem nacional idealizado pelo Estado Novo deveria apresentar os padrões de conduta defendidos pela narrativa esportiva exposta acima. O trabalhador disciplinado e produtivo seria a matriz racial do brasileiro. O ideal de homem estadonovista deveria cooperar, agir disciplinadamente, ser uno e homogêneo ${ }^{209}$. Nesse período, criou-se o mito do trabalhador ordeiro e esforçado, cumpridor de seus deveres para com a nação:

“... Quais são as aspirações das massas obreiras, quais os seus interesses? E eu vos responderei: A ordem e o trabalho! Em primeiro lugar, a ordem, porque na desordem nada se constrói (...) O trabalho só de pode desenvolver em ambiente de ordem” ${ }^{210}$.

O futebol auxiliava o Estado a uniformizar, de acordo com as suas normas e ideais, a pátria em chuteiras. O compartamento dos jogadores em campo e as opiniões dos jornalistas contrárias a individualismos, rebeldias e violência dentro de campo foram fundamentais para moldar a massa torcedora de acordo com os padrões do governo varguista.

Nesse contexto, a categoria dos jogadores de futebol foi regularizada pelo governo estadonovista, em julho de 1939. Na reunião de fundação do primeiro Sindicato dos Jogadores Profissionais de Futebol destacaram-se os seguintes jogadores: Walter, Romeu, Batataes, Machado, Hercules, Adilson, Og, Villa, Yustrich, Possato, Jarbas, Valtente, Fogueira, Novelli, Odir. A cerimônia foi presidida por um

\footnotetext{
${ }^{209}$ LENHARO, Alcir. Op. cit., p. 104.

${ }^{210}$ VARGAS, Getúlio. Op. cit., p. 203 apud MARTINS, Heloisa Helena Teixeira de Souza. Op. cit. p. 36.
} 
representante do Ministério do Trabalho, Moacyr Mesquita, e assistida pelo representante da Ordem Pública e Social, Raphael Amadeu, no Rio de Janeiro ${ }^{211}$.

Nessa reunião inaugural formou-se uma comissão executiva para elaboração do estatuto da nova associação de classe formada por: Presidente, Walter Goulart; Vicepresidente, Hercules Miranda; Primeiro Secretário, Dorival Kuiipell (Yustrich); Segundo Secretário, Adilson Ferreira Arante; Primeiro Tesoureiro, Leônidas da Silva; Segundo Tesoureiro, Luis Villa. O novo sindicato, de acordo com a nota, a despeito de já contar com cem adesões seria reconhecido oficialmente somente no dia 15 de julho do mesmo ano ${ }^{212}$.

O Mundial de Futebol disputado na França, em 1938, foi exaustivamente divulgado pela imprensa para educar a massa nos moldes da ideologia estadonovista. De acordo com Wisnik, esse torneio foi a "epifania" do futebol brasileiro como meio de divulgação do Brasil no exterior ${ }^{213}$. Pela primeira vez, a escalação do selecionado nacional continha os melhores jogadores em atuação no país, não importando o seu estado de origem ou sua raça ${ }^{214}$.

Os jornais do período acompanharam todos os passos do selecionado, exaltando as suas atuações, destacando Domingos da Guia e Leônidas da Silva como os melhores jogadores do mundo em suas posições e indignando-se contra a arbitragem na semifinal, contra a Itália ${ }^{215}$.

\footnotetext{
${ }^{211}$ Correio Paulistano, 2 de julho de 1939. p. 12

${ }^{212}$ loc. cit.

${ }^{213}$ WISNIK, José Miguel. Op. cit., p. 183.

${ }^{214}$ Sobre a presença de negros na Seleção brasileira durante o Mundial de 1938, Gilberto Freyre declarou em 15 de junho de 1938: "Creio que uma das condições da victória dos brasileiros nos encontros europeus, prende-se ao fato de termos tido a coragem de mandar à Europa, desta vez, um team francamente afro-brasileiro. Tomem os arianistas nota disso”. Gazeta de Notícias, 16 de junho de 1938, p. 10.

${ }^{215}$ A campanha da Seleção Brasileira de futebol no Mundial de 1938 foi a seguinte: Brasil 6 x 5 Polônia
} 
Nessas matérias eram destacadas a união e a harmonia do conjunto brasileiro, suas atuações cavalheirescas e o patriotismo dos jogadores, pois essas eram as qualidades projetadas pelo governo estadonovista internamente e que deveriam ser divulgadas no exterior.

O discurso em favor da ordem e disciplina pode ser verificado na declaração do técnico do selecionado brasileiro, Adhemar Pimenta, após a conquista do terceiro lugar no Mundial de Futebol de 1938, em 14 de julho do mesmo ano:

\begin{abstract}
"Em todas as ocasiões mostraram-se [os jogadores paulistas] elles perfeitos cavalheiros, acatando sem discussão as ordens e cumprindo-as com boa vontade (...) É com prazer que faço essa referência aos jogadores paulistas, que souberam honrar a nossa embaixada, comportandose em todos os momentos como perfeitos esportistas que prezam a palavra disciplina” 216 .
\end{abstract}

A declaração do treinador revela-se ambígua com relação ao alinhamento do esporte aos padrões estipulados pelo governo. A rivalidade regional presente no comentário de Pimenta quando esse dividiu a seleção brasileira em um grupo de jogadores paulistas e outro de atletas cariocas, era um elemento considerado nocivo ao projeto de unidade nacional estadonovista.

Porém, esse regionalismo apareceu em segundo plano na entrevista, pois o técnico exaltou o cavalheirismo, a cordialidade e a disciplina presentes nos jogadores paulistas. Esses valores transformavam os atletas em verdadeiros heróis nacionais, na medida em que divulgaram de maneira grandiosa a imagem brasileira no exterior.

Além disso, deve-se destacar a ironia presente na declaração de Pimenta ao representar os jogadores como verdadeiros esportistas, leais e disciplinados, pois o segundo jogo do Brasil no Mundial de Futebol de 1938, contra a Tchecoslováquia, foi

(na prorrogação, em 4 de junho de 1938), Brasil 2 x 2 Tchecoslováquia (em 12 de junho de 1938), Brasil 2 x 1 Tchecoslováquia (no jogo de desempate, em 14 de junho de 1938), Brasil 1 x 2 Itália (em 16 de junho de 1938). O segundo gol italiano foi conseguido com um pênalti que a imprensa brasileira considerou ilegítimo. Na disputa do terceiro lugar do torneio, em 19 de junho, o resultado foi Brasil 4 x 2 Suécia.

${ }^{216}$ Correio Paulistano, 14 de julho de 1938, p. 10. 
marcado pela violência dentro de campo com dois jogadores brasileiros expulsos ${ }^{217}$.

Além disso, o lance vital da semifinal contra a Itália que causou a desclassificação do selecionado brasileiro, foi fruto de uma jogada de violência de Domingos em um futebolista italiano quando a bola não estava em jogo. Os porta-vozes do governo reclamaram da marcação não acreditando que o lance realmente pudesse ter ocorrido de um selecionado tão cavalheiresco e harmônico.

A realidade era que, apesar dos esforços governistas, o futebol brasileiro demonstrava para o exterior algumas das principais características de nossa sociedade, a saber: o individualismo, desrespeito às regras e violência.

Nessa empreitada de moldar o futebol de acordo com os princípios estadonovistas, os jornais também representavam a massa torcedora como um conjunto harmônico, sem conflitos e individualismos, através de fotografias (muitas delas publicadas nas capas dos periódicos) em que a multidão era representada como uma coletividade dócil, patrioticamente se despedindo, torcendo ou recebendo seus heróis nacionais de regresso ao país após terem defendido as cores e o bom nome do Brasil no exterior.

${ }^{217}$ Jornal dos Sports, 13 de junho de 1938. 


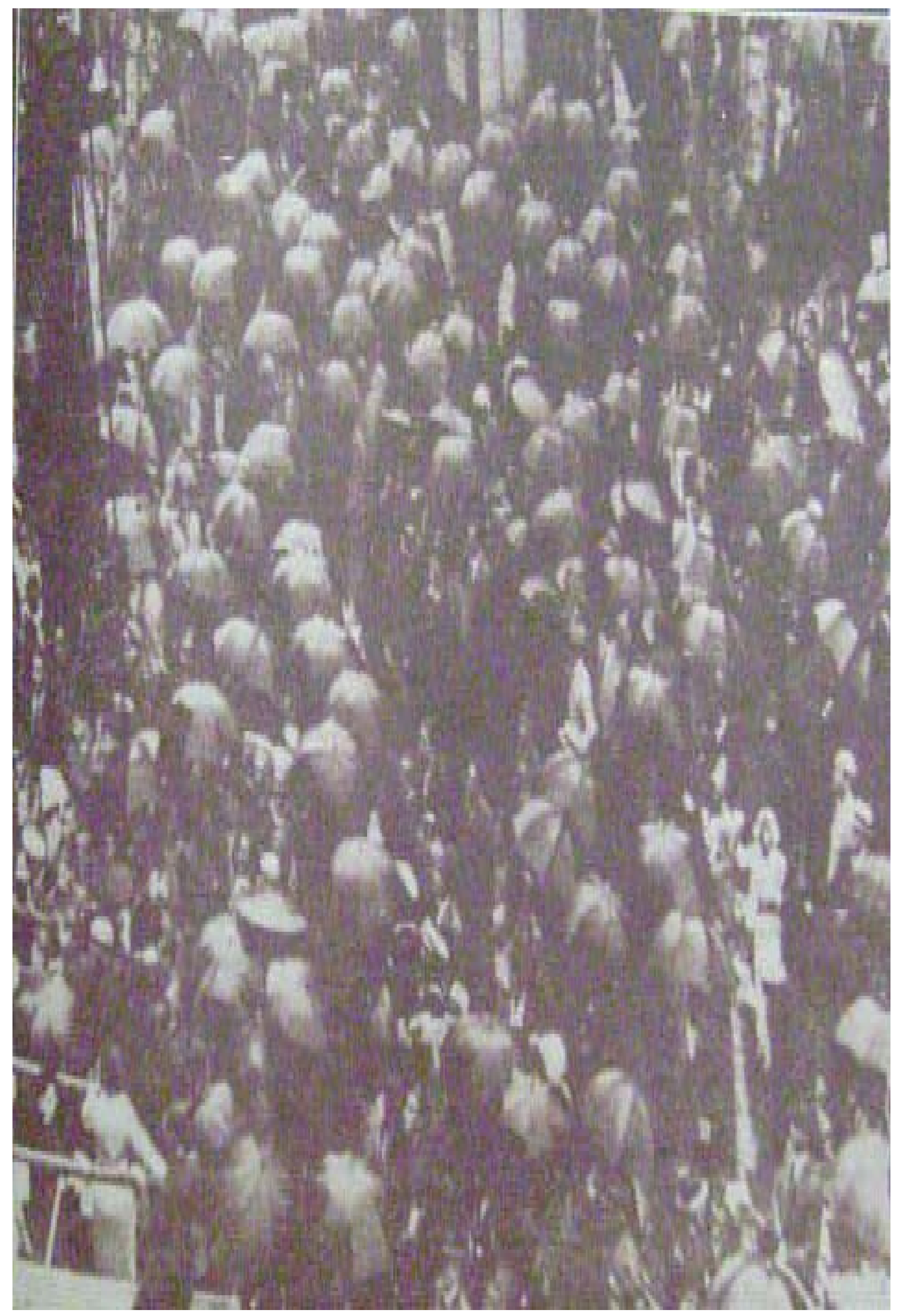

Foto da multidão que, apesar da forte chuva, foi se despedir da seleção quando essa embarcava para disputar o Campeonato Mundial de Futebol, na França. Gazeta Esportiva, 02 de maio de 1938, p. 5. 


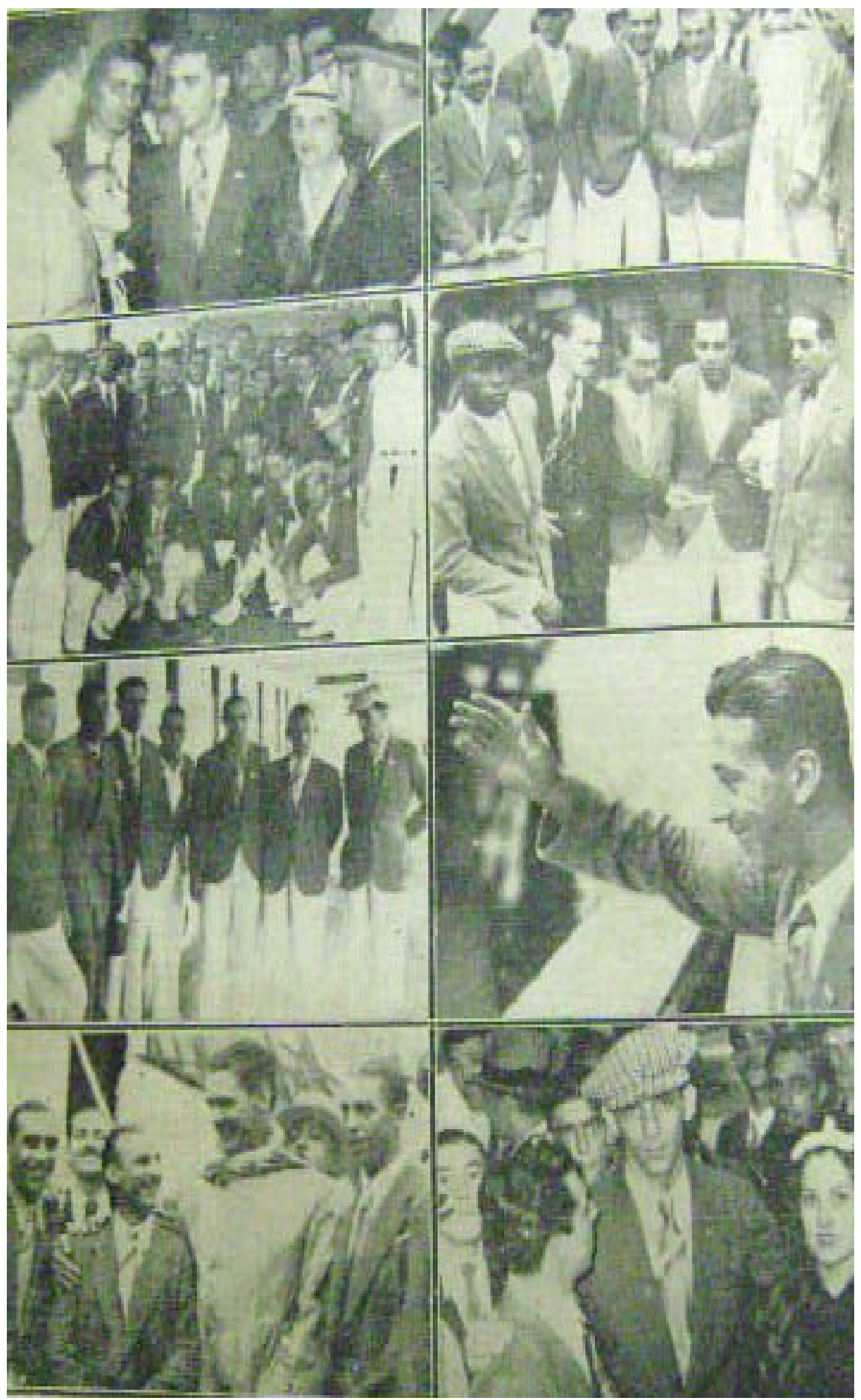

Imagens dos jogadores brasileiros a bordo do navio Arlansa durante o embarque para a disputa da Copa do Mundo de Futebol, em 1938. A maior parte das fotos traz os jogadores em grupos, representando uma coletividade harmonica e feliz em defender a imagem do Brasil no exterior. Além disso, percebe-se a presença de jogadores negros vestindo o mesmo estilo de roupas que os demais jogadores e membros da comissão. Por fim, vale destacar como as cenas fotografadas lembram a despedida de combatentes que foram para a Europa, atuar no front. Gazeta Esportiva, 02 de maio de 1938, p. 6. 
O contexto beligerante presente no período estadonovista contribuiu para a ordenação, via militarização, da sociedade e de seu futebol. Nesse período, alguns tipos de guerra encontraram legitimidade, como o futebol e a Segunda Guerra Mundial, cuja adesão brasileira foi declarada em agosto de 1942; enquanto outros foram repudiados, como a guerra constituída pela oposição democrática versus o governo autoritário praticante de perseguições, torturas e censuras.

Alguns elementos presentes no futebol conferem-lhe semelhanças com as guerras como as estratégias e táticas presentes em sua organização, o uso de uniformes nas partidas, os nomes de alguns clubes (como o clube inglês Arsenal) e de torcidas uniformizadas de futebol, os cânticos de motivação, a entonação dos hinos nacionais antes dos jogos internacionais, a presença de bandeiras e escudo nos clubes, a linguagem para denominar algumas posições em campo (como o “capitão” e o “artilheiro matador”), as partes integrantes do jogo (como a “meta”) e da própria partida, a "peleja” 218 .

Desse modo, é possível compreender a adoção no futebol brasileiro do esquema tático diagonal no qual o centro defensivo sempre estava preenchido, em detrimento ao WM utilizado na Europa com sua marcação individual e, consequente, maior espaço em campo $^{219}$. Enquanto no velho continente a guerra era declarada, franca, aberta e noticiada diariamente ao mundo, no Brasil a guerra promovida pelo Estado contra seus opositores era silenciosa, escamoteada, com mínimas brechas para os ataques inimigos.

Tanto no futebol, como na Segunda Guerra Mundial e na guerra entre o Estado autoritário e seus opositores, o objetivo de conquistar o território e expulsar o inimigo

\footnotetext{
${ }^{218}$ FRANCO JUNIOR, Hilário. Op. cit., pp. 235-236.

${ }^{219}$ Para uma análise mais consistente sobre os esquemas táticos como forma-representação do jogo de futebol, sempre atualizados durante os treinos, ver: TOLEDO, Luíz Henrique de. Op. cit., p. 164.
} 
constituiu-se fundamental. No futebol essa missão se processou pela ocupação dos espaços no campo e, em seu ponto máximo, quando a própria "meta" existente no espaço adversário era atingida constituindo o goal (palavra inglesa que significa de “objetivo”).

Na Segunda Guerra ficou famosa a tática dos combatentes em sobrevoar o território inimigo e dizimá-lo com bombas para depois invadi-lo. No caso da guerra realizada pelo Estado Novo, a conquista de território era interna como se os opositores impedissem esse de realizar a tão desejada unificação nacional e, por isso, mereciam ser exilados do país e afastados definitivamente do território nacional em litígio.

A preparação do selecionado brasileiro para disputar a Copa Roca em janeiro de 1940, ilustrou o relacionamento existente entre a guerra real e o futebol, pois foi realizada pelo tenente Ambrósio, instrutor da Escola de Educação Física do Exército, no quartel general da Rua Manoel da Nóbrega em São Paulo ${ }^{220}$.

Nesse contexto, o Correio Paulistano publicou a seguinte declaração do marechal inglês, Harold Alexander:

\footnotetext{
“- 'Nossa guerra faz lembrar o futebol inglês onde existe 'players' que atuam na defesa, outros que coordenam a defesa e o ataque e os 'fowards' nos quais incubem os arremessos finais, marcando os pontos. Mas, não é o marcador de 'goals' que ganha o jogo, mas sim o quadro todo’. Trata-se da $1^{\mathrm{a}}$ vitória do futebol, no que concerne a sua aplicação como paradigma, para os lances da guerra em curso" 221.
}

As palavras do "comandante supremo das forças aliadas no Mediterrâneo” firmam-se como ícones na relação entre esses dois diferentes estilos de peleja, pois enfatizavam as semelhanças existentes entre o futebol e a guerra, destacando a força do conjunto existente em ambos.

Em janeiro de 1942, concomitante à realização do $14^{\circ}$ Campeonato Sulamericano de Futebol disputado em Montividéu, ocorreu a conferência entre os

\footnotetext{
${ }^{220}$ Gazeta de Notícias, 28 de janeiro de 1940, p. 14.

${ }^{221}$ Correio Paulistano, $1^{\circ}$ de dezembro de 1944, p. 11.
} 
países latino-americanos realizada no Rio de Janeiro, onde acertou-se uma aliança entre esses países e seus rompimentos com aqueles integrantes do Eixo, concretizando o posicionamento do governo brasileiro em relação à guerra na Europa ${ }^{222}$.

Essa polarização mundial em Eixo e Aliados interferiu nos nomes de alguns clubes futebolísticos no Brasil pois as cores, o uniforme e o escudo desses não poderiam mais representar países do Eixo, agora inimigos brasileiros incontestes.

Assim, logo após a declaração de guerra brasileira, os Palestras Itália de São Paulo e de Belo Horizonte tiveram seus nomes alterados para Palmeiras e Cruzeiro dois elementos tipicamente brasileiros, assim como suas novas cores verde - branco e azul - branco, respectivamente ${ }^{223}$.

Outros clubes foram extintos como a Associação Alemã de Esportes após sua fusão com o São Paulo Futebol Clube, proporcionado a este último a criação do departamento de basquete, esporte então denominado de cestobol ${ }^{224}$.

Nesse contexto, outra regularização no futebol foi realizada pelo Conselho Regional de Desportos do Estado de São Paulo, de acordo com o item número dois, do artigo sexto presente no Decreto-lei número 12.758, de 17 de junho de 1942. Essa regulamentação proibiu a participação de pessoas provenientes de países do Eixo em competições esportivas no Brasil independente de atuarem como jogadores, técnicos ou sócios de clubes. Medidas drásticas, porém em conformidade ao projeto do governo em fazer dos esportes um dos sustentáculos do processo criativo da nação brasileira ${ }^{225}$.

\footnotetext{
${ }^{222}$ Correio Paulistano, 25 de janeiro de 1942.

${ }^{223}$ As mudanças nos nomes dos Palestra Itália de São Paulo e Belo Horizonte foram assuntos nas seguintes publicações: Correio Paulistano, 15 de março de 1942, p. 17 e Correio Paulistano, 18 de setembro de 1942, p. 5. Sobre o assunto, Hilário Franco Junior escreveu que o Goiás Esporte Clube, fundado em 1943, iria igualmente se chamar Palestra Itália, mas alterou o nome para não sofrer represálias. FRANCO JUNIOR, Hilário. Op. cit., p. 84.

${ }^{224}$ Correio Paulistano, 25 de março de 1942, p. 8.

${ }^{225}$ Gazeta Esportiva, 5 de outubro de 1942, p. 2.
} 
Sobre a atuação de estrangeiros no futebol brasileiro, Mário Filho escreveu a seguinte matéria:

“A filiação em massa de Ligas tornará complexa a missão do órgão máximo da capacitação. E como a Federação não poderá collocar-se em um plano equidistante pelas exigências políticas, transformou-se em um organismo inútil e perigoso. Sem prestígio, mas com um farrapo de lei. Sem forças mas com armas traiçoeiras (...) A Federação 'suggere' na ansia vindicta [sic] que só 'brasileiros natos' possam presidir organizações do foot-ball, o 'único sport que precisa nacionalizar-se'... Depois de um acto semelhante a Federação Brasileira não tem mais moral para dirigir o foot-ball. Para dirigir coisa alguma. Já não é mais entidade” ${ }^{226}$.

Na ocasião, o jornalista carioca teceu duras críticas à Federação Brasileira de Futebol, afirmando ser essa uma entidade ilegítima, sem moral para dirigir o esporte nacional. Além disso, a notícia constitui-se sintomática ao destacar que a nacionalização esportiva foi exigida somente para o futebol, o que demonstra a importância desse esporte para o projeto estadonovista de padronização social.

A uniformização no futebol realizada pelo Estado autoritário interferiu, inclusive, nos nomes utilizados pelos jogadores. Em agosto de 1945, a Confederação Brasileira de Desportos considerou como não cavalheiresco a nomeação dos profissionais da bola com apelidos ${ }^{227}$.

Assim, para não vulgarizar a imagem da nação brasileira no exterior e extinguir um dos sintomas da força dos relacionamentos interpessoais em nossa soiciedade em detrimento da concretização das instituições, instituiu-se essa medida regularizadora do decoro futebolístico.

\footnotetext{
${ }^{226}$ Jornal dos Sports, 30 de abril de 1939, p. 2.

${ }^{227}$ Correio Paulistano, 5 de agosto de 1945, p. 8.
} 


\subsection{Leônidas: O Anjo Caído}

Os jogadores de futebol muitas vezes são considerados ídolos, heróis e, até mesmo, santos de seus clubes quando operam verdadeiros milagres. Eles constituem o elo entre os fiéis torcedores e os deuses clubísticos ${ }^{228}$. Sua fama transcende os campeonatos, sendo miticamente reforçada pela oralidade presente da cultura popular com suas histórias, lendas e mitos.

Nesse contexto, o embate épico entre Domingos e Leônidas da Silva, excompanheiros no Flamengo, e heróis nacionais da Copa do Mundo de Futebol disputada em Paris, foi destacado pelo Jornal dos Sports $^{229}$. Do mesmo modo, Figliola foi considerado "a chave do triunfo" na vitória do Vasco da Gama no amistoso contra o Corinthians Paulista ${ }^{230}$.

O modelo ideal de futebolista para os paulistas, durante o Estado Novo, era o ex-jogador do Paulistano, seleção paulista e brasileira, Arthur Friedenreich. Apesar de ter atuado na revolta de 1932 contra o Estado ${ }^{231}$, o governo estadonovista reconhecia a sua influência e utilizava constantemente a figura do El Tigre para moldar os leitores de São Paulo, mesmo após o encerramento da sua carreira futebolística, na forma de seus princípios. Sobre esse jogador, a Gazeta Esportiva publicou o seguinte texto:

"Bem sabemos quão audacioso é o nosso empreendimento ao inscrever o nome do veterano 'player' [sic] ao lado das figuras máximas na conquista do ar [Santos Dumont], no engrandecimento da arte [Carlos Gomes], na personificação robusta do talento [Ruy Barbosa]. Contudo, ainda que ousado, não vacilamos em colocar junto daquelas individualidades levadas às culminâncias da glória, a personalidade de Arthur Friedreich. Ele o merece, sob

\footnotetext{
${ }^{228}$ FRANCO JUNIOR, Hilário. Op. cit., pp. 260-261.

229 Na edição 29 de outubro de 1942, por ocasião do jogo Flamengo versus São Paulo, disputado no Pacaembu, um dia antes.

${ }^{230}$ Jornal dos Sports, 20 de fevereiro de 1943. A partida ocorreu um dia antes, no Pacaembu.

${ }^{231}$ A atuação de Friedenreich no movimento paulista de 1932 contra o governo central será analisada no capítulo V: O jogo das elites.
} 
todos os aspectos. O valor de um personagem de projeção internacional está na razão direta dos benefícios que ele conquistou para a sua Pátria. Pouco importa em que modalidade, de que forma, de que maneira foram obtidas tais conquistas. O que a Pátria deseja são vitórias em quaisquer campos, para engrandecimento de nacionalidade, para orgulho de seus filhos. Nada mais justo, pois, que a glorificação daqueles que, como Friedreich, tanto fizeram e tanto pugnaram para tornar maior a terra que lhes serviu de berço” ${ }^{232}$.

Para o jornalista paulista o futebolista poderia fazer parte do panteão nacional, pois heroicamente realizou serviços em favor da pátria, engrandecendo-a e promovendo orgulho aos seus cidadãos. Sua imagem sintetizava valores caros ao regime como disciplina, humildade, caldeamento étnico e esforço eugênico.

Porém, durante o Estado Novo, sem dúvida alguma o ídolo da multidão foi Leônidas da Silva, o “Diamante Negro”. Nascido em 1912, Leônidas praticava futebol nas ruas da Ponte dos Marinheiros, próxima à Cidade Nova no Rio de Janeiro. Aos doze anos ingressou no time de escoteiros do São Cristovão, de onde saiu um ano depois para jogar em clubes pequenos em busca de melhores remunerações.

Em 1931, Leônidas transferiu-se do Sírio para o Bonsucesso, clube da primeira divisão da AMEA (Associação Metropolitana de Esportes Athléticos). Após ter a sua transferência para o América frustrada, graças ao preconceito racial que imperava no clube carioca, o jogador foi contratado pelo Flamengo, clube em que atuou até ser transferido para o São Paulo Futebol Clube (após passagem pelo Peñarol do Uruguai) 233

Entre os seus maiores feitos encontram-se a artilharia da Copa do Mundo de 1938, a negociação mais vultuosa do período estadonovista e a sua contribuição para fazer um clube recém fundado, como o São Paulo Futebol Clube, se transformar em um dos três maiores da paulicéia.

Ao analisar a figura do herói, Roberto DaMatta destacou a tragédia, a trajetória

\footnotetext{
${ }^{232}$ Gazeta Esportiva, 4 de janeiro de 1941, p. 6.

233 Sobre os dados biográficos de Leônidas da Silva e o preconceito racial que impediu sua transfrência para o América, ver: PEREIRA, Leonardo. Op. cit., pp. 313 e 319, respectivamente.
} 
tortuosa, cheia de peripécias e desmascaramentos como elementos sempre presentes na vida dessas personagens. Afim com essa concepção, a história construída em torno da figura de Leônidas da Silva foi realizada a partir das superações profissionais e sociais que o jogador realizou ao longo de sua vida:

“... sempre narramos e ficamos deveras fascinados com contos de enriquecimento e ascenção social violenta e irremediável do herói. Ou seja, a base do drama é fazer o personagem central terminar com muito mais do que possuia quando da abertura da estória (...) Realmente sempre começamos com alguém muito pobre e desgraçado, alguém que está lá embaixo, nos porões do mundo social. E obviamente terminamos com sua ascenção social fulminante (...) Mas, e este ponto precisa ser bem acentuado, naquele personagem havia pobreza e desgraça, mas nunca mediocridade ou falta de nobreza. De fato, o sujeito estava muito bem marcado desde o início da estória por algum sinal particular, traço ineludível do seu caráter especial, sempre revelado por nós de modo substantivo" ${ }^{234}$.

Marcado desde o início por sua mestiçagem, valorizada pelo Estado Novo como representante de seus valores eltistas, a esse herói ligou-se um mito fundador, o da jogada "bicicleta”. Famoso pela sua elasticidade, Leônidas fez em gramados brasileiros a jogada uruguaia “chaleira”, sendo aqui denominada igual a um dos objetos símbolos dos novos tempos; como se a modernidade latino-americana fosse intrinsecamente brasileira, construída no Brasil e pelo Estado Novo.

Os heróis tipicamente brasileiros não se apresentam como o grande exemplo sem caráter, eles seriam figuras deslocadas das regras formais da estrutura social, avessos ao trabalho, mais afim com a conquista fácil, realizada graças ao dom natural $^{235}$. Sobre a associação existente entre as concepções de malandro e de herói, Roberto DaMatta escreveu:

"Essa anti-ingenuidade, essa habilidade em transitar nas zonas fronteiriças da regra, desafiando o limite entre o permitido e o proibido, é uma qualidade de que os brasileiros costumam se orgulhar. Chamam isso de malandragem. E os malandros, além de personagens do quotidiano, são heróis do imaginário social” ${ }^{236}$.

\footnotetext{
${ }^{234}$ DAMATTA. Roberto. Op. cit., p. 199.

${ }^{235}$ DAMATTA. Roberto. Op. cit., p. 204.

${ }^{236}$ DAMATTA. Roberto (Org). Op. cit., p. 107.
} 
A própria vinculção entre a figura do herói com a do malandro na sociedade e, consequentemente, no futebol brasileiro, simboliza o orgulho em relação à malandragem presente no país:

“A sociedade brasileira adora esse vingador ingênuo e engraçado [o malandro]. Aqui é necessário ser humilde para surpreender e humilhar os que se julgam fortes e invencíveis. É preciso dissimular, pretextando modéstia, para se impor. Estimular a auto-confiança alheia para enganar e vencer o adversário" ${ }^{237}$.

Essas figuras altamente individualizadas têm como armas principais a astúcia e o ridículo e, por meio dessas, vingam-se do sistema social sem, no entanto, tentar alterá$l^{238}$. Como exemplo desta vingança social capaz de influenciar a massa de torcedores aficcionados, destaca-se a declaração de Leônidas sobre a eleição presidencial de 1945.

Enquanto a União Nacional dos Estudantes iniciava a Semana Nacional Pró Anistia em 1945, e Vargas assinava o Decreto-lei número 7.474 concedendo-a para aqueles que foram presos por motivos políticos desde julho de 1934, e marcando eleições democráticas para o final do ano, o ídolo futebolístico Leônidas da Silva declarava que o seu voto iria para o candidato do Partido Comunista Brasileiro ${ }^{239}$.

A individualidade e astúcia, próprias dos malandros, estava na forma de Leônidas jogar futebol. Assim, construiu-se a noção de um estilo brasileiro de jogar futebol em torno de sua figura e atuação: cheio de ginga, dribles e fintas. Essa concepção estilística encontra-se ainda presente no inconsciente coletivo, conforme demonstrou essa afirmação de DaMatta:

\footnotetext{
${ }^{237}$ Idem. Ibidem. p. 108.

${ }^{238}$ Idem. Ibidem. p. 258.

${ }^{239}$ A entrevista foi realizada na concentração da seleção brasileira, em Caxambu, durante os preparatórios para a Copa Roca de 1945. Correio Paulistano, 29 de novembro de 1945, p. 14.
} 
“A catimba é um dos aspectos que assume a malandragem no futebol. O drible é outro. A valorização da finta é uma característica do nosso estilo de jogo. Driblar o adversário é uma fascinação. Uma finta define um malandro e o seu otário” 240.

A figura desse futebolista e a construção de um estilo festivo de jogar futebol realizado em torno do ídolo popular mestiço e rebelde conflitava diretamente com os ideais do Estado Novo e a sua tentativa de vingar um estilo futebolístico disciplinado e ordenado.

O fato de Leônidas ser carioca, negro e proveniente das camadas populares da sociedade permitia a associação imediata do herói ao estereótipo do malandro, presente na cultura popular brasileira e antítese da figura do trabalhador criada pelo Estado Novo. Sua imagem representava o axioma preto versus branco presente na sociedade, proveniente da herança escravista ainda latente no período estadonovista ${ }^{241}$.

Nesse conflito entre a mestiçagem libertária, o estilo individualista e malandro de jogar futebol representado por Leônidas e sintonizado com os valores das classes populares versus a exaltação de uma mestiçagem comportada e da prática futebolística baseada em padrões elitistas defendida pelo regime, o preconceito racial aparecia de modo escamoteado, pois se festejavam as qualidades tidas como inerentes da raça no trato com a bola, ao mesmo tempo em que se associava o herói futebolista ao bandido, malandro e ex-escravo.

Sobre essa tensa relação entre o que era exaltado pela massa no futebol e o ideal nacional defendido pelo governo e introjetado na sociedade, Leonardo Pereira destacou o preconceito racial presente na defesa realizada por Mário Filho a Leônidas da Silva, no início da carreira do jogador:

“Enquanto descrevia Leônidas em campo ‘sacudindo os braços, como um macaco’ Mário Filho

\footnotetext{
${ }^{240}$ DAMATTA. Roberto (Org). Op. cit., p. 107.

${ }^{241}$ WISNIK, José Miguel. Op. cit., p. 199.
} 
ia formando sobre ele uma imagem que tinha por base características tidas como imanentes aos jogadores negros, como a ginga que lhes permitia fazer as suas 'macaquices' - em um termo que, explicitando o preconceito que ainda se escondia por trás de sua admiração, evidenciara o caráter quase natural atribuído ao seu talento. Mais do que permitido, a presença desses jogadores no selecionado parecia agora desejada, a partir de uma visão que fazia deles os portadores de um jeito especial de jogar que os diferenciava dos atletas brancos que até então representaram a cidade e o país” ${ }^{242}$.

A despeito do preconceito racial escamoteado na sociedade brasileira a valorização da mestiçagem promovida pelo Estado Novo, o crescimento da imprensa esportiva e a divulgação dos jogos de futebol realizada pelo rádio contribuíram para tornar os jogadores verdadeiros astros do cenário esportivo da cidade, conquistando inúmeras vantagens financeiras.

A figura de Leônidas foi utilizada inúmeras vezes para vender produtos, pois sua semelhança física, origem social e feitos futebolísticos o aproximava dos operários do regime, a massa torcedora. O jogador era o garoto-propaganda da goiabada Peixe e dos Cigarros Leônidas, corporificando o próprio produto a ser vendido ${ }^{243}$.

\footnotetext{
${ }^{242}$ PEREIRA, Leonardo. Op. cit., p. 315.

${ }^{243}$ NEGREIROS, Plínio José Labriola de Campos. Op. cit., p. 306.
} 


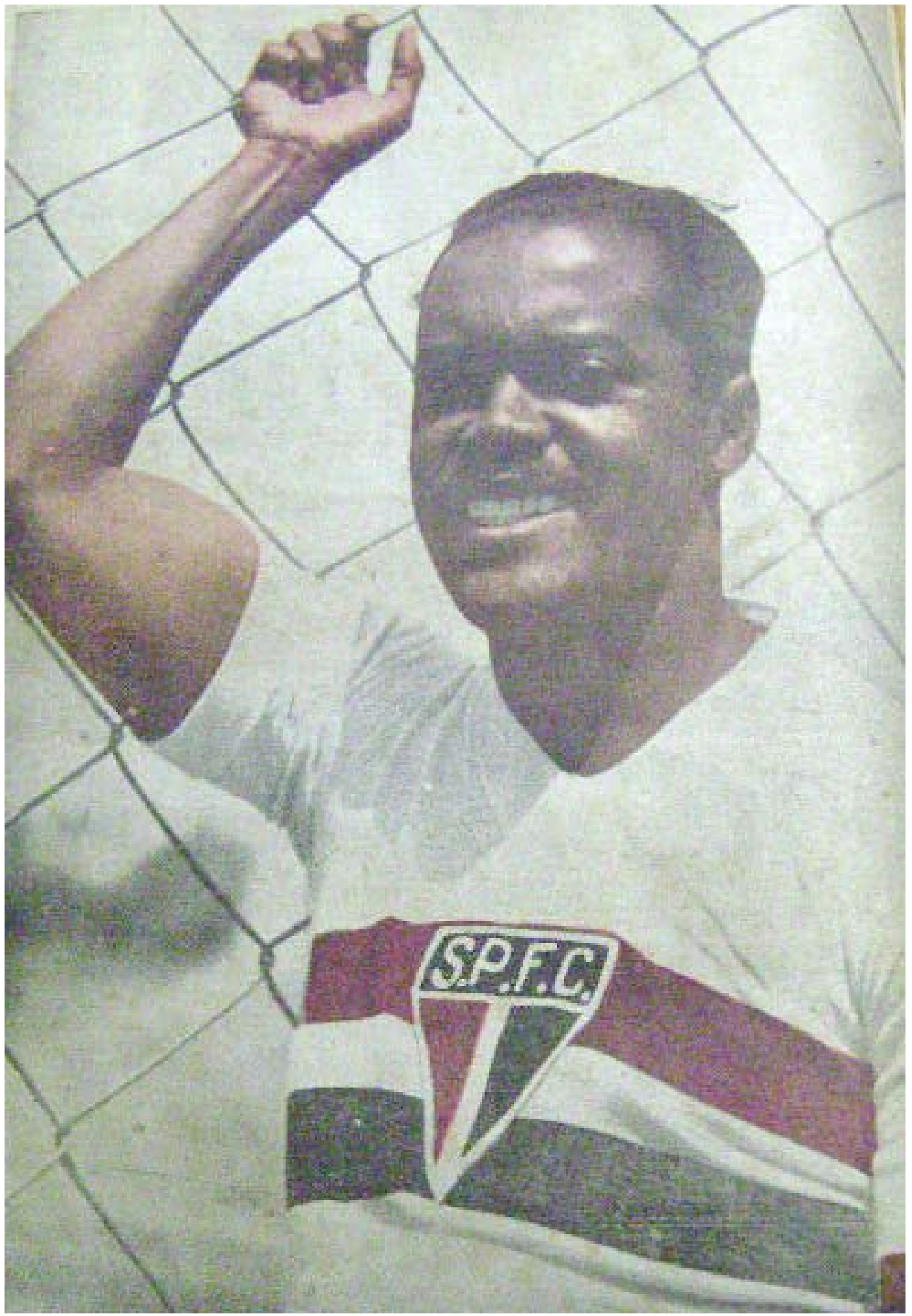

Leônidas foi contratado pelo São Paulo Futebol Clube após ter saído da prisão e decido não permanecer no C R Flamengo. Apesar das propostas para atuar em outros clubes, inclusive do Palestra de São Paulo, o tricolor paulista contratou o jogador por 80 contos, sendo que 20 contos seriam pagos na contratação, em 04 de abril de 1942, outras duas parcelas de 25 contos seriam pagas posteriormente e 10 contos iriam para o seu advogado. A nota ainda esclareceu o valor que Leônidas iria ganhar por dois anos de atuação no clube paulista: 75 contos. Correio Paulistano, 05 de abril de 1942, p. 14. Foto publicada em Gazeta Esportiva, 16 de junho de 1943, p. 16. 


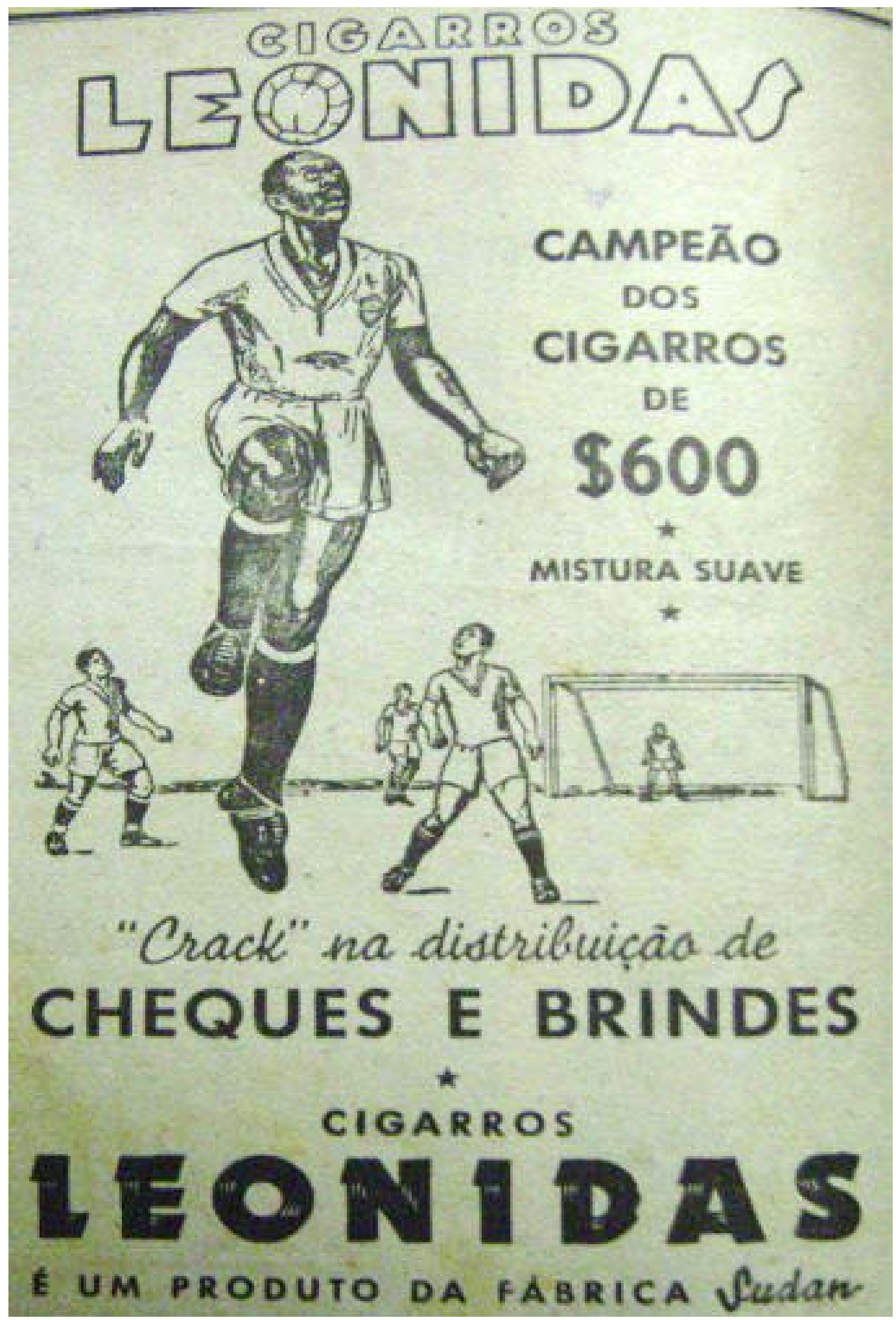

Propaganda da marca de cigarro Leônidas que destacava o desenho do Diamante Negro com o escudo da CBD bordado na camisa. Os demais jogadores presentes na imagem, brancos, olham boquiabertos para Leônidas, que ostenta a sua habilidade com a bola. Como apelo publicitário, o cigarro recebeu a mesma caracterização que o jogador: ambos eram “cracks”. Gazeta Esportiva, 25 de maio de 1942, p. 8. 
Porém, apesar da sua popularidade, utilizada diversas vezes como forma de propaganda, graças a sua mestiçagem e origem social, Leônidas teve por diversas vezes sua imagem vinculada às notícias de caráter policial:

\begin{abstract}
"Vem de ter, finalmente, seu epílogo a rumurosa questão em que Leônidas se viu envolvido, acusado que foi pelo barbeiro Rosário Lizzio de o haver agredido com um pontapé na cabeça. $\mathrm{O}$ juiz da $4^{\circ}$ Vara Criminal, em fundamentada sentença absolveu Leônidas, visto que as provas não tinham consistência (...) a própria vítima não pode precisar de o ferimento recebido foi em conseqüência de qualquer ação de Leônidas ou em virtude de queda” ${ }^{244}$.

O modo como foi estruturada a notícia causava uma dúvida no leitor em relação ao acerto da sentença, pois o jornalista escreveu sarcasticamente no final da matéria que a absolvição foi baseada no fato de o acusador não ter como provar se o ferimento era da agressão ou de uma queda.
\end{abstract}

Outra notícia criminosa ligada à vida do futebolista consistiu na suspeita de roubo formulada pela Associação Metropolitana de Futebol para cortá-lo do selecionado carioca. Essa seleção tinha como base os jogadores do elitista América F C, que não queriam atuar com Leônidas da Silva por ele ser negro ${ }^{245}$. Vale lembrar que o preconceito racial existente entre diretoria, sócios e jogadores desse mesmo clube foi o principal motivo que impediu a transferência de Leônidas do Bonsucesso para o América F C.

Em um regime constituído por ideais elitistas, eugênicos, burocráticos e racionais a adoração popular de Leônidas fomentava uma conflituosa relação entre os valores do regime e o ídolo da massa. Algumas vezes, os jornais publicavam uma caricatura do futebolista ressaltando sua malandragem, descompromisso e rebeldia mas, em outras situações, enalteciam suas realizações dentro de campo, salvadoras da nação.

Durante o carnaval de 1940, a Gazeta de Notícias publicou a seguinte nota

\footnotetext{
${ }^{244}$ Jornal do Comércio, 14 de março de 1945, p.6.

${ }^{245}$ PEREIRA, Leonardo. Op. cit., p. 321.
} 
sobre o sumiço de Leônidas durante os preparativos para a Copa Roca:

“O 'Diamante' desapparecera e ninguém sabia aonde elle andava. Entretanto, achamos que a busca não foi feita a rigor, pois o popular 'crack' esteve durante as quatro noites de Carnaval no 'High-Life' e, quando não nos ‘bars’ da Glória. Enfim o 'rapaizinho' é mestre e pode fazer dessas tolices sem 'prejuízo’ da selecção nacional” ${ }^{246}$.

A sua rebeldia não podia ser disfarçada, pois estava presente em seu modo descompromissado e gingado de jogar, como se estivesse à margem dos esquemas táticos. O fato de ter atuado no Uruguai, abandonando o futebol brasileiro, demonstrava o seu descompromisso para com os ideais nacionais em construção naquele momento.

Do mesmo modo, a sua transferência do futebol carioca para o paulista acirrou as paixões regionalistas, constituindo outro ponto conflituoso entre a prática futebolista e os ideais estadonovistas. Sobre isso, analisa-se a matéria publicada no Jornal dos Sports:

"A príncipio os clubes cariocas pareciam contentar-se com elementos disponíveis e afora o caso Leonidas, no qual o São Paulo aproveitou-se bem da desinteligência havida com o Flamengo, as demais preocupações chegaram a preocupar. Agora, entretanto, o caso está mudando de figura, e no curto prazo de duas semanas lá se foram Caxambú e Oswaldo, enquanto Santamaria e Domingos estão sendo assediados e até influenciados a ficarem mais a vontade para migrar (...) O ponto de partida para a reação deve ser, sem dúvida, a exigência que a lei seja respeitada sem subterfúgios. Desde que isso não seja possível, outros recursos devem ser estudados para evitar o mal enquanto é tempo" ${ }^{247}$.

A reportagem expressou a rivalidade presente entre o futebol praticado por São Paulo e Rio de Janeiro, nociva ao projeto de unidade nacional do governo de modo contundente. Para o jornalista, a transferência de Leônidas abriu precedentes para os clubes paulistas continuarem assediando os bons jogadores cariocas - fato considerado extremamente danoso ao futebol da capital federal.

Porém, em outros momentos, a rebeldia de Leônidas era contornada pelo

\footnotetext{
${ }^{246}$ Gazetas de Notícias, 08 de fevereiro de 1940, p. 11.

${ }^{247}$ Jornal dos Sports, 26 de maio de 1943, p. 2.
} 
regime com a finalidade de utilizar a imagem do futebolista para exaltar alguns de seus princípios. Para jogar na Copa Roca em 1940, o Diamante Negro entrou na Argentina sem passaporte, pois Vargas interveio junto ao governo argentino para permitir o seu acesso às terras portenhas sem o referido documento ${ }^{248}$. O fato demonstra como a vitória da seleção brasileira de futebol em terras estrangeiras era considerada de vital importância para a boa publicidade do Brasil no exterior.

Nessa tensa e delicada relação de poder, o Estado Novo puniu Leônidas com oito meses de prisão (na época de sua operação de menisco), pela falsificação de sua carteira de reservista $^{249}$. Caberia ao governo dar exemplo à sociedade sem cair no erro de transformar o santo futebolístico em mártir.

O conflito existente entre os valores projetados à sociedade pelo Estado Novo e aqueles provenientes da figura de Leônidas ficou caracterizada no comentário do leitor Tomé Cardoso Borges:

“... uma coisa acabou para sempre: o seu prestígio: foi o de adquirir um certificado militar de modo irregular que bem se vê que, com os destinos da Pátria, não há prestígios, recursos ou ignorância que possa demover ou convencer a digna jurisprudência da Justiça Militar brasileira. Eis o fim de um admirável prestígio" ${ }^{250}$.

A reprodução dessa carta no períodico representa como a imprensa foi amplamente utilizada pelo governo para concretizar sua ideia de nação. Não pode ser considerado fruto do acaso a divulgação de um comentário tão afim com os ideais do Estado Novo.

O comentário do leitor demonstrou como estavam presentes os valores de disciplina e nacionalismo na sociedade do período. Para Borges, a atitude de Leônidas

\footnotetext{
${ }^{248}$ Correio Paulistano, 2 de março de 1940, p. 8.

${ }^{249}$ Entrevista de Leônidas da Silva ao Museu da Imagem e do Som de São Paulo, em 7 de janeiro de 1976 (Fitas 45.1 e 45.1-2).

${ }^{250}$ Carta publicada na Gazeta de Notícias, em 30 de julho de 1941, p.10.
} 
de se abster em lutar pela sua nação foi imperdoável e merecedora de punição. Assim, percebe-se que a aceitação do negro e do mestiço na sociedade do período ocorria mediante a incorporação de valores brancos e elitistas como disciplina, trabalho e coletivismo, em suas atitudes e personalidades.

Para finalizar o capítulo, deixa-se um ponto a ser analisado. Talvez, se possa compreender a permanência no inconsciente coletivo brasileiro de um estilo de jogar futebol voltado ao espetáculo, fruto do dom dos artistas da bola, construído a partir de ídolos como Leônidas da Silva, em contraposição ao estilo técnico e burocrático representado pelos ideais estadonovistas, como resultado de uma resposta popular ao autoritarismo do regime.

Sendo assim, com a vitória discursiva do futebol-arte construído e preferido pelas massas, em detrimento ao futebol-força praticado com refinamento técnico e projetado pelo Estado Novo, é possível perceber uma das ofensivas populares sofridas pelo regime. 


\section{A VOZ DA ORDEM}

\subsection{Nas Entrelinhas do Poder}

De acordo com Benedict Anderson, os jornais seriam obras de ficção cujas notícias formam comunidades imaginadas entre seus leitores. Essa identificação ocorreria de duas formas: pela coincidência cronológica existente entre os fatos divulgados e pela relação entre as empresas e o mercado ${ }^{251}$.

Assim, o jornal constitui-se como uma “cerimônia de massa”, pois o seu consumo como ficção traz uma noção de pertencimento aos leitores, apesar de o ato de ler ser individualmente realizado:

“... a ficção se infiltra contínua e silenciosa na realidade, criando aquela admirável confiança da comunidade no anonimato que constitui a marca registrada das nações modernas ${ }^{252 »}$.

Como os jornais analisados durante a pesquisa de mestrado eram representantes dos interesses elitistas e da ideologia estadonovista, os projetos e as reivindicações das classes trabalhadoras e dos grupos minoritários não eram contemplados em seus editoriais. A “grande imprensa” objetiva atrair o público para as ideologias defendidas por seus donos e, concomitantemente, ter lucro com a sua publicação $^{253}$.

Assim, por meio da ação política exercida cotidianamente nesses jornais por

\footnotetext{
${ }^{251}$ ANDERSON, Benedict. Op. cit., pp. 65-66.

${ }^{252}$ Idem. Ibidem. p. 68.

253 CAPELATO, Maria Helena Rolim. Os arautos do liberalismo: Imprensa paulista 1920-1945. São Paulo: Brasiliense, 1988a. p. 15.
} 
membros do governo, intelectuais e jornalistas liberais, decorrente das suas produções e publicações de textos, o controle das classes populares e a criação de uma elite pensante nos problemas nacionais foram efetivados nos moldes de um Estado conservador e autoritário $^{254}$.

A propriedade dos principais jornais em São Paulo desde a época imperial, pertencia aos grandes fazendeiros cafeicultores. Com as notícias publicadas em seus jornais esse grupo social organizou-se politicamente contra o Império, pediu o final da escravidão e exigiu a instauração da República ${ }^{255}$.

Nesse período, o principal objetivo dessas publicações era divulgar as ideias liberais de seus donos, ou seja, os textos tinham um perfil eminentemente político. Com base nos princípios iluministas as classes dominantes colocavam-se para elas próprias a missão de ensinar o povo a lidar com o poder proveniente da sua soberania ${ }^{256}$.

Após a Primeira Guerra Mundial, com o desenvolvimento tecnológico decorrente do contexto bélico e a maior objetividade presente nas relações sociais, os jornais adquiriram um perfil mais comercial, passando a ser editados em maior escala e atingindo um número maior de leitores.

Em 1933, de acordo com Silvana Guimarães, circulavam cerca de um mil e quinhentos jornais (entre cotidianos e periódicos), quatorze mil pessoas eram empregadas nas redações, administrações e impressões de jornais, quinhentas e cinquenta máquinas planas e cento e setenta máquinas rotativas funcionavam e

\footnotetext{
${ }^{254}$ CAPELATO, Maria Helena Rolim. Os intérpretes das luzes. Liberalismo e imprensa paulista; 19201945. Tese de Doutorado - FFLCH/ USP. São Paulo, 1986. p. I.

${ }^{255}$ Idem. Ibidem. p. 11.

${ }^{256}$ Idem. Ibidem. pp. 3-7.
} 
setecentos jornais tinham suas próprias oficinas ${ }^{257}$.

O caratér empresarial dos jornais os tornavam mais manipuláveis, obrigando seus proprietários a cederem às exigências do poder, aos pedidos dos anunciantes e às solicitações dos leitores. Dos anúncios e comerciais provinha a maior parte de seus lucros, enquanto através do número de leitores, além da rentabilidade conseguida pelas vendas de periódicos, eram concretizados seus prestígios em termos de ideias e força política.

Durante o Estado Novo, para fazer da imprensa um dos serviços públicos do regime havia, na Divisão de Imprensa do DIP, o Conselho Nacional de Imprensa para julgar as ações cometidas por jornalistas contra sua própria categoria, leitores ou nação; a Agência Nacional, cuja função era produzir as notícias escritas pelo regime e o Serviço de Controle à Imprensa, encarregado de realizar a censura nos periódicos.

O DIP conseguia agir contra a liberdade de expressão na imprensa, pois controlava as concessões de insenções da taxa para adquirir o papel utilizado na fabricação dos periódicos (que eram provenientes do exterior em pequena quantidade, devido à guerra mundial).

Além disso, esse órgão censurava os textos publicados no país, controlava as agências telegráficas, estreitava a área de atuação dos correspondentes estrangeiros, vigiava as empresas de publicidade e tinha poder para agir contra todas as gráficas com seus respectivos equipamentos e trabalhadores ${ }^{258}$.

A censura era realizada de dois modos distintos pelo Estado Novo, a saber:

\footnotetext{
${ }^{257}$ GUIMARÃES, Silvana Goulart. Ideologia, propaganda e censura no Estado Novo. Dissertação de Mestrado - FFLCH/ USP. São Paulo, 1984. p. 88.

${ }^{258}$ MELO e SOUZA, José Inácio. Op. cit., p. 220.
} 
previamente e após a publicação do texto. Inicialmente, ela era feita pelo departamento policial porém, quando essa tarefa passou a ser realizada pela Divisão de Imprensa do DIP, sem a truculência habitual da polícia, de modo mais sutil e impessoal, os jornais a sentiram com mais intensidade.

O Serviço de Controle à Imprensa (SCI) censurava qualquer notícia sobre o regime anterior à instauração do Estado Novo, assim como era proibida a vinculação do governo às referências não democráticas, a publicação de matérias sobre o comunismo e elogiosas à Rússia. Críticas ao DIP e a divulgação de problemas existentes nesse eram igualmente censuradas. As notícias relativas aos atos do governo deveriam ser publicadas após a efetivação de tais atos, via versões oficiais, para evitar especulações $^{259}$.

O SCI proibia sistematicamente a publicação de notícias sobre as agências do governo como o Departamento do Café. Comentários relativos à carestia de alimentos provocada pela guerra mundial e sobre a saúde pública (como as notícias relativas à febre tifóide, em 1942) eram proibidos. Censuravam-se notícias sobre discussões salariais, movimentos grevistas e litígios entre empregados e patrões. Do mesmo modo, era vedada a publicação de discursos oposicionistas, notícias sobre o movimento estudantil, informações sobre anistia política e, inclusive, comentários sobre as comemorações do movimento paulista de $1932^{260}$.

Notas sobre a participação brasileira na guerra, relativas à movimentação militar no mundo e sobre acidentes com aviões brasileiros transportando material bélico eram cuidadosamente trabalhadas pelo SCI, sendo a maioria delas divulgadas por nota

\footnotetext{
${ }^{259}$ GUIMARÃES, Silvana Goulart. Op. cit., pp. 200-201.

${ }^{260}$ Idem. Ibidem. pp. 203-204.
} 
oficial $^{261}$.

Referências à censura postal foram proibidas em 1943. Um ano depois, começaram a examinar as notícias sobre política extrangeira, os telegramas do exterior, as cartas e memoriais enviados ao presidente. No mesmo ano, coube ao SCI resolver sobre a liberação de documentos coletivos, como manifestos, proclamações e convites. Em 1945, nenhuma matéria ou foto poderia ser liberada para publicação sem a autorização do $\mathrm{SCI}^{262}$.

Nessa prática autoritária, as notícias polêmicas eram proibidas pelo SCI. Silvana Guimarães exemplificou esse tipo de censura com um episódio ocorrido em dezembro de 1944, quando os cronistas esportivos foram advertidos para não publicarem coisa alguma sobre o último Campeonato Brasileiro de Futebol, com a finalidade de não acirrar os ânimos e provocar mais desentendimentos entre as entidades paulistas e cariocas de futebol. A partir dessa data, os comentários esportivos ficaram sujeitos à censura prévia ${ }^{263}$.

Além de realizar a censura nos meios de comunicação, o Estado Novo comprava espaços nos jornais para vincular seus ideais de forma sutil, fazendo um leitor menos atento acreditar que a matéria era fruto da redação de cada periódico. Essa “propaganda em gotas”, caracterizada por Guimarães, garantiu ao governo estadonovista legitimação e força para concretizar seus projetos ${ }^{264}$.

De acordo com o Decreto-lei ${ }^{\circ}$ 1949, artigo 13, de 30 de dezembro de 1939,

\footnotetext{
${ }^{261}$ Idem. Ibidem. p. 206.

${ }^{262}$ Idem. Ibidem. pp. 207-209.

${ }^{263}$ Idem. Ibidem. p. 206.

${ }^{264}$ Idem. Ibidem. p.195.
} 
os jornais deveriam, obrigatoriamente, trazer artigos, comentários, editoriais ou notícias gerais para esclarecer a opinião popular sobre os planos de construção material e ideólogica da nação engendrados pelo governo.

Sobre essa intromissão governamental na produção jornalísitica no período, a historiadora Maria Helena Capelato informou ser de sessenta por cento a quatidade de matérias fornecidas pela Agência Nacional e publicadas nos jornais ${ }^{265}$.

Essas notícias vinham prontas, com determinações sobre a página onde deveriam ser inseridas, quais deveriam ser os destaques e os tipos de fontes a serem utilizados na publicação.

A interferência governamental deve também ser analisada pelas sanções materias prometidas aos jornais rebeldes, caso não obedecessem às regulamentações do regime para esse setor. As ameaças consistiam na retirada da publicidade federal e privada (o governo solicitaria para a empresa retirá-la se fosse necessário) e no controle das cotas de papel, pois essas eram retiradas na alfândega apenas com autorização governamental, conforme o Decreto-lei $n^{0}$ 300, de 7 de março de 1938 e deveriam ser pagas em vinte e quatro horas ${ }^{266}$.

De acordo com o artigo 131, do já citado Decreto-lei $\mathrm{n}^{0} 1.949$, as empresas jornalísticas igualmente seriam punidas se realizassem, diretamente ou não, campanha contra a unidade nacional. A ocorrência desse fato seria interpretada como um ato contra a segurança nacional interna e degradante à soberania do país no exterior.

Por esse autoritarismo e controle exercido pelo governo estadonovista em prol da concretização de seus ideiais, deve-se analisar os periódicos como ambientes de lítigio, nos quais diferentes classes sociais disputavam um lugar para divulgar suas ideologias e projetos, a fim de controlar grande parte da população.

\footnotetext{
${ }^{265}$ CAPELATO, Maria Helena Rolim. Op. cit., p. 109.

${ }^{266}$ Idem. Ibidem. p.116.
} 
Nada nos periódicos encontrava-se por acaso. O tamanho da matéria, seu lugar de publicação, o tipo de fonte e imagem utilizada em sua construção constitui-se fundamental para compreender como se processou essa luta pelo poder.

Do mesmo modo, é necessário analisar o passado da empresa jornalística, seus proprietários, diretores, linguagem, preço e a destinação da publicação, pois esses elementos constituem-se significativos para a interpretação de quais interesses eram defendidos pelos diferentes grupos sociais em combate.

O jornal paulista Correio Paulistano foi fundado em 1854, já inovando ao apresentar os cargos de diretor e editor, sendo o primeiro cargo ocupado por seu criador Joaquim Roberto de Azevedo, e o segundo por Pedro Taques de Almeida Alvim. Sua sede era à Rua Libero Badaró, número 661, no centro de São Paulo.

Em seu subtítulo, “Órgão do Partido Republicano Paulista”, estava a ideologia norteadora de suas publicações. A despeito de ser empastelado, ter seus bens confiscados (deixados a cargo de um depositário) e ver suas oficinas anexadas à Imprensa Oficial por apoiar o movimento paulista contra o governo varguista em 1932, esse epíteto perdurou até dois meses após a instauração do Estado Novo.

O número médio de cada publicação era de dezessete páginas, sendo as primeiras folhas compostas por comentários políticos pró-governo, notícias de atos promovidos pelo regime em benefício da pátria, reportagens sobre o estado do Rio de Janeiro e dos demais estados do interior do país e notas sobre a guerra europeia.

No meio do jornal estavam as notícias culturais, sobre o cotidiano da cidade com as colunas sociais e programação de cinemas e rádios, as notas militares e jurídicas. No final das edições encontravam-se as notícias econômicas, relativas ao comércio e agricultura, telegramas retidos, ocorrências policiais, anúncios, classificados e notas de 
última hora.

As edições dominicais eram compostas por um número maior de páginas, contendo um segundo caderno com matérias voltadas ao público feminino. As notícias esportivas eram publicadas, normalmente, na oitava página com as chamadas “Esportes”, “Ao correr da pena...” (que continha crônicas raramente publicadas), "Resenha dos fatos esportivos” e "Notas cariocas" (espaço para publicar notícias esportivas decorrentes das atividades praticadas no Rio de Janeiro com destaque ao futebol).

Nos dois últimos meses de 1937, o Correio Paulistano custava diariamente duzentos réis e podia ser assinado em outros países. Outras localidades no país podiam recebê-lo semestralmente por trinta contos de réis, e anualmente por cinquenta e cinco contos de réis. Os cargos presentes no jornal eram o de redator-chefe e superintendente, sendo o primeiro crgo ocupado por Alberto Americano até $1^{\circ}$ de dezembro, quando foi substituído pelo representante do DIP Abner Mourão, e o segundo cargo pertencente a Antonio M. de Oliveira Cesar.

De janeiro a junho de 1938, o Correio Paulistano trouxe em sua capa algumas mudanças como um quadro informativo sobre suas sucursais em Santos, Campinas e Rio de Janeiro, destacando seus diretores e endereços e o novo subtítulo, "Fundado em 1854”, cujo intuito era rementer à tradição do jornal e proporcionar maior legitimação aos ideais nele contidos. 


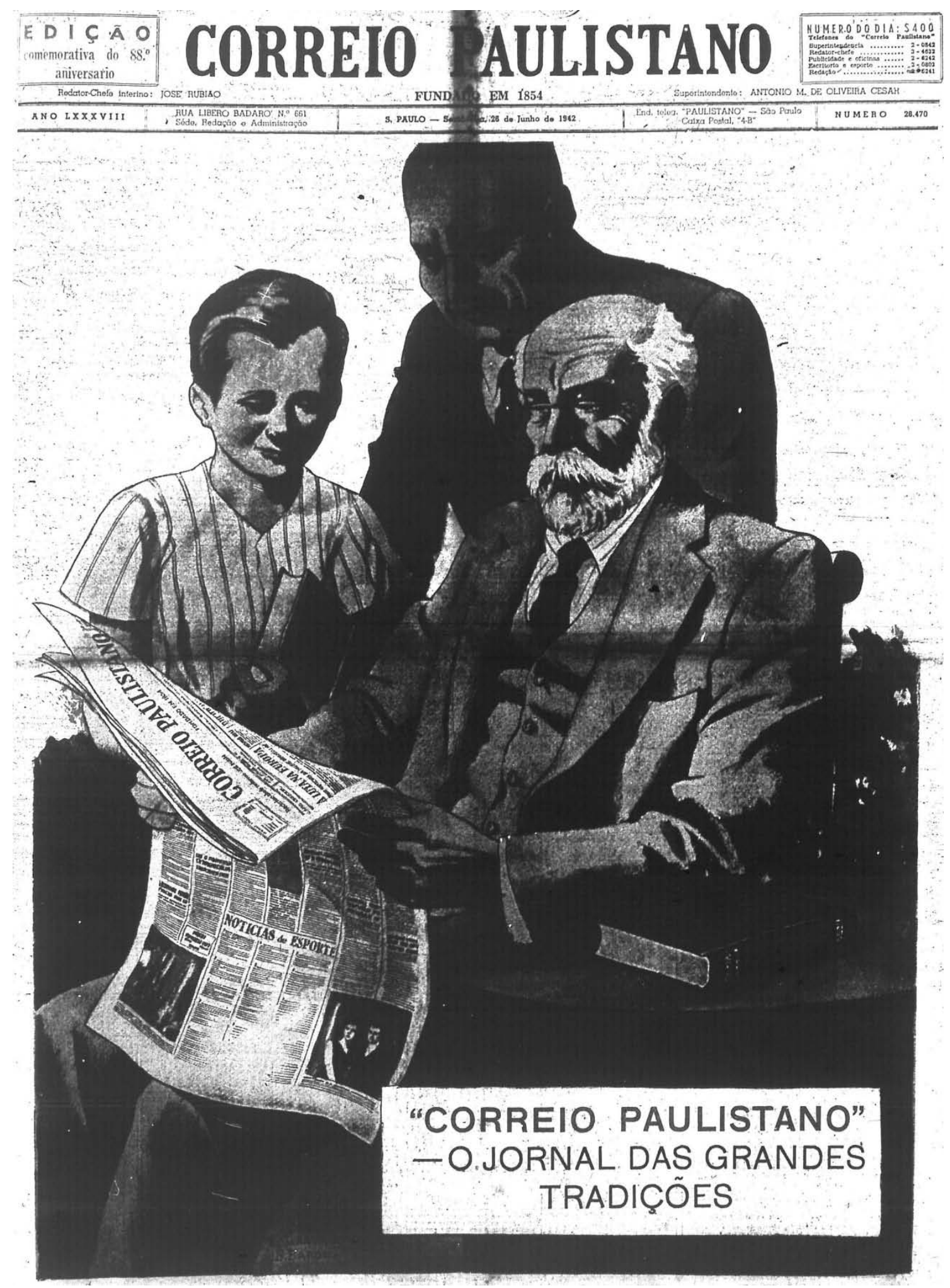

Imagem comemorativa do $\mathbf{8 8}^{\circ}$ aniversário do Correio Paulistano, apresentando o novo subtítulo "Fundado em 1854". A despeito da frase presente no quadro em destaque, “O jornal das grandes tradições”, a tradicional e elitista história do jornal estava simbolizada pelas três gerações, representadas por três verdadeiros cavalheiros que liam o periódico. Correio Paulistano, 26 de junho de 1942, p. 1. 
Outros dois periódicos de grande circulação durante o Estado Novo eram os cariocas Gazeta de Noticias e Jornal do Comércio. Devido à impossibilidade de se encontrar nos arquivos pesquisados um jornal do Rio de Janeiro contendo todas as edições diariamente publicadas e conservadas durante o período estudado, foi necessário pesquisar até 1941 utilizando a Gazeta de Notícias, e realizar a análise de 1942 a 1945 pelo Jornal do Comércio.

A Gazeta de Notícias estava sediada na Rua do Ouvidor, número 104, no centro do Rio de Janeiro. De dezembro de 1937 a julho de 1938, esse periódico trouxe em sua capa o subtítulo “O jornal de mais tradição no Brasil” procurando, assim como o Correio Paulistano, uma legitimação calcada no ideal de tradição para as opniões nele publicadas.

As edições eram compostas por dezoito páginas, em média, e suas seções eram bem definidas, com suas divisões presentes na paginação desde agosto de 1938. No início das publicações encontravam-se os editoriais e as matérias relativas à política praticada pelos países estrangeiros. Os telegramas, notas sobre educação, matérias sobre economia e finanças e cotidiano da cidade encontravam-se entre a quinta e nona página.

Finalizando as edições publicavam-se as notícias sobre direito, conclusões dos editoriais das primeiras páginas, notas sindicais e aquelas de última hora. As matérias esportivas encerravam as edições, sendo separadas as notícias sobre corridas de cavalos daquelas relativas aos demais esportes.

O Jornal do Comércio era igualmente sediado no centro da capital do país, na Avenda Rio Branco, número 177. Seu subtítulo "Propriedade de Rodrigues \& Comp.” trazia outro tipo de legitimação, não apelativa à tradição, mas baseada nos ideais burgueses e liberais enaltecedores da propriedade e de sua representação classista. 
Durante os anos analisados, os cargos administrativos do jornal não sofreram nenhuma alteração, sendo a gerente Dora Rodrigues Pacheco, e Elmano Cardim o diretor. Essa estabilidade pode representar a sintonia do jornal com os interesses do Estado Novo, fruto de sua constituição elitista.

Em média, as edições do Jornal do Comércio continham dezesseis páginas, sendo essas divididas da seguinte maneira: no início das publicações estavam as notas sobre os atos governamentais, sumário da edição, telegramas, matérias sobre política internacional e a guerra, decretos assinados e as notícias do interior. No meio da publicação encontravam-se as matérias jurídicas, sobre o cotidiano da cidade (com programações de teatros, cinemas e rádio), previsão do tempo e notícias policiais.

Finalizando as edições, eram publicadas as notícias comerciais, notas católicas, avisos, editais, avisos fúnebres, informações de última hora, matérias esportivas e uma grande quantidade de anúncios e classificados.

Outros períodicos de grande circulação no período estadonovista eram aqueles voltados aos esportes. A Gazeta Esportiva foi adquirida por Casper Líbero em 1918, com sérios problemas econômicos. Sofreu empastelamento em 1930, sendo recuperada dois anos depois quando recebeu um valor para reparar o ato autoritário. Essa indenização possibilitou a compra de um maquinário de qualidade e a inauguração da nova sede em julho de 1939, deixando a Rua Libero Badaró, números 645 e 652, para se localizar em prédio próprio, na Rua Conceição, número 6.

Consolidada uma empresa próspera no final da década de 30, para comemorar tal estabilidade a Gazeta Esportiva publicou na capa de $1^{\circ}$ de janeiro de 1939 ilustrações comemorativas com os dizeres “A Gazeta cresce com São Paulo”. No final de 1941, para firmar sua posição junto ao Estado Novo, suplantando os desafetos de 32, a Gazeta 
trouxe a seguinte frase: "São Paulo nunca esteve divorciado, como se pretendeu demonstrar, do grande Chefe Nacional” 267.

No interior desse períodico era publicado às segundas-feiras, desde 24 de dezembro de 1928, o suplemento Gazeta Esportiva com dezesseis páginas, em média, por edição. Em 10 de outubro de 1947, esse suplemento tornou-se um periódico diário, vendido separadamente.

O periódico esportivo paulista era conhecido pela importância que conferia ao fato, concebido como o relato direto e preciso do acontecimento. Para reforçar essa exatidão ao fato publicado, o jornal utilizava uma grande quantidade de fotografias nas notícias, transmitindo-as como imparciais e verdadeiras.

Outro periódico esportivo analisado foi o carioca Jornal dos Sports, idealizado e comandado por Mário Filho, o responsável pela modernização estilística nos jornais do gênero. Sua linguagem de fácil compreensão, narrativas detalhadas sobre os jogos, entrevistas com esportistas, estímulos às rivalidades, criação de concursos e a grande quantidade de fotos proporcionavam uma efetiva participação das classes mais populares nos veículos de comunicação, majoritariamente comandado e acessível à elite ilustrada do país.

O Jornal dos Sports, cujo epíteto era "O diário mais completo e de maior circulação na América do Sul”, tinha sua sede na Avenida Rio Branco, número 129, no centro do Rio de Janeiro. Em seu comando estavam o secretário Everardo Lopes, o gerente Henrique Gigante e o diretor Mário Rodrigues Filho que comprou o jornal com

\footnotetext{
${ }^{267}$ CAPELATO, Maria Helena Rolim. Op. cit., p. 115. O historiador Plínio Negreiros demarcou A Gazeta como um jornal alinhado ao regime varguista e que buscava ser popular. NEGREIROS, Plínio José Labriola de Campos. Op. cit., p. 55.
} 
o auxilio financeiro dos amigos Arnaldo Guinle, Bastos Padilha e Roberto Marinho, em $1936^{268}$. Suas edições eram compostas, em média, por seis páginas.

Notícias sobre esportes e espetáculos, a presença de ilustrações, fotografias e caricaturas nas matérias e a publicação de folhetins nos jornais eram elementos muito utilizados para atrair o grande público e, assim, propagar os valores do Estado Novo para um maior número de cidadãos.

Na década de 30, do século XX, uma conjunção de fatores contribuíram para fazer do futebol o esporte representativo da identidade nacional, como o processo de profissionalização e as transmissões radiofônicas que o propagou para diferentes setores sociais e permitiu a sua utilização pelo Estado na concretização de seus ideais ${ }^{269}$.

Assim, a função básica da imprensa durante o Estado Novo era descobrir os desejos e paixões das massas e vinculá-los aos princípios do regime construindo uma identificação entre as classes populares e os ideais estadonovistas.

O aspecto ritualístico desse esporte capaz de despertar fortes sentimentos e identidades foi amplamente trabalhado pela imprensa durante o Estado Novo, com a censura e publicação de matérias escritas pelo próprio governo, como demonstrado a seguir.

\footnotetext{
${ }^{268}$ Sobre o patrocínio que permitiu Mário Filho comprar o jornal ver ANTUNES, Fátima Martin Rodrigues Ferreira. Op. cit., p. 107.

${ }^{269}$ CALDAS, Waldenyr. “Aspectos sócios políticos do futebol brasileiro”. Revista USP, n² 22, p. 40-49, jun./jul./ago, 1994. p. 45.
} 


\subsection{A Crônica Esportiva por Mazzoni e Mário Filho}

Analisar a luta pelas representações na História constitui elemento de fundamental importância, tanto quanto estudar os embates econômicos de uma sociedade para compreender como diferentes grupos sociais impõem, ou tentam impor, sua concepção do mundo social, seus valores e domínio ${ }^{270}$.

De acordo com Roger Chartier, o conceito de "representação" e a sua articulação com o mundo social processa-se da seguinte forma:

“... em primeiro lugar, o trabalho de classificação e de delimitação que produz as configurações intelectuais múltiplas, através das quais a realidade é contraditoriamente construída pelos diferentes grupos; seguidamente, as práticas que visam a fazer reconhecer uma identidade social, exibir uma maneira própria de estar no mundo, significar simbolicamente um estatuto e uma posição; por fim, as formas institucionalizadas e objectivadas graças às quais uns 'representantes' (instâncias coletivas ou pessoas regulares) marcam de forma visível e perpetuada a existência do grupo, de classe ou de comunidade” ${ }^{271}$.

Quando aplicada essa teoria à literatura, esta é percebida como um campo de litígio, fruto de variáveis históricas e sociais. Assim, não existe neutralidade na relação texto-leitor; o primeiro extrapola seu conteúdo semântico, enquanto que o segundo se apropria do texto com práticas históricas e socialmente variáveis ${ }^{272}$.

Por meio da literatura os conflitos entre os diferentes grupos sociais podem ser analisados pela relação escrita-leitura, pois a prática literária não se limita à construção

\footnotetext{
${ }^{270}$ CHARTIER, Roger. A historia cultural. Entre práticas e representações. Lisboa: Difel, 1990. p. 17.

${ }^{271}$ Idem. Ibidem. p.23.

${ }^{272}$ Idem. Ibidem. p.25.
} 
e dominação ideológica por parte de quem escreve, podendo proporcionar a reapropriação, o desvio e a resistência em seu leitor ${ }^{273}$.

Nesse contexto, o papel da imprensa esportiva como um dos veículos de propagação da ideologia estadonovista foi destacado por Salim Helou, cronista do Correio Paulistano:

“... O cronista moderno é produto das massas. Conhecedor das suas nuances psíquicas, dá a ela o que ela pede: emoção (...) Transformam o quadro numa família de todo mundo. E como membro desta família, o público compartilha de suas intimidades. Nascem controvérsias e com elas polêmicas calorosas. O contágio é geral (...) O Brasil é um campo de futebol, disse alguém com clarividência de profeta. Sendo um esporte das multidões, como se proclama orgulhosamente, o futebol deveria ter uma orientação mais patriótica, processando imediatamente uma reeducação na mentalidade dos torcedores (...) Ao cronista compete a sagrada missão de reeducar. Basta para tanto moderar a linguagem, despindo-a de termos excitantes" ${ }^{274}$.

De acordo com a matéria, deveria o jornalista se apropriar da função de educar as massas de acordo com os valores do regime, utilizando seus textos como verdadeiras narrativas da ordem. Para Helou, a melhor maneira de escolher a metodologia desse ensino consistiria em conhecer as paixões da multidão pois, partindo das suas experiências vividas, os valores seriam compreendidos mais facilmente pelo povo. Sobre a função educadora desempenhada pelos cronistas, Plínio Negreiros destacou:

\footnotetext{
"De um lado, faziam dos seus ofícios quase que uma militância, pois entendiam que a função de um cronista esportivo - ou antes de mais nada, um jornalista - era contribuir para a educação da população. Daí o tom professoral das suas crônicas” ${ }^{275}$.
}

Assim, o futebol como ritual misto, se aproximava do povo ao representar o

\footnotetext{
${ }^{273}$ Idem. Ibidem. p.59.

${ }^{274}$ Correio Paulistano, 26 de outubro de 1944, p.11.

${ }^{275}$ NEGREIROS, Plínio José Labriola de Campos. Op. cit., p. 58.
} 
aspecto festivo da paidia, ao mesmo tempo em que servia aos interesses do Estado como ludus, ou seja, elemento disciplinador e regrado. Por esse seu caráter ambíguo, o futebol constitui a paixão de diferentes classes sociais da sociedade brasileira e, desse modo, foi utilizado como um dos meios de divulgação da ideologia estadonovista.

Porém, ressaltou Helou, o cronista esportivo deveria ter cuidado com os seus textos pois, caso contrário, poderia exaltar a massa contra os mesmos princípios que deveriam ser por ela compreendidos e aceitos.

As ideologias presentes no período estadonovista transpareciam nos periódicos esportivos, pois além da censura imposta à imprensa que fazia ser publicado o que era interessante ao governo os jornalistas, como sujeitos históricos, vivenciaram os debates postos na sociedade e participaram ativamente do conflituoso jogo entre as classes sociais, cujo objetivo consistia em fazer seus ideais propagarem para um maior número de pessoas.

Sendo assim, analisam-se os dois maiores periódicos esportivos do país, a paulista Gazeta Esportiva e o carioca Jornal dos Sports, e como estes realizaram essa missão de propagar a ideologia estadonovista e educar a massa torcedora nos moldes autoritários quando escreviam suas narrativas da ordem. Além disso, as sutilezas e ironias desse discurso igualmente serão analisadas para se entender como as atores sociais utilizaram o futebol para burlar o autoritarismo estadonovista.

O futebol estava presente nas edições dos jornais, por notícias sobre os jogos das rodadas passadas, colocação dos clubes nas tabelas dos campeonatos, em entrevistas realizadas com profissionais ligados ao esporte, nas coberturas das concentrações antes das grandes partidas, com a promoção de concursos ligados a esse esporte (como o da melhor torcida uniformizada, promovido pela Gazeta Esportiva), com propaganda de 
produtos utilizando linguagem ou personagens futebolísticos, entre outros inúmeros exemplos de notícias baseadas no futebol.

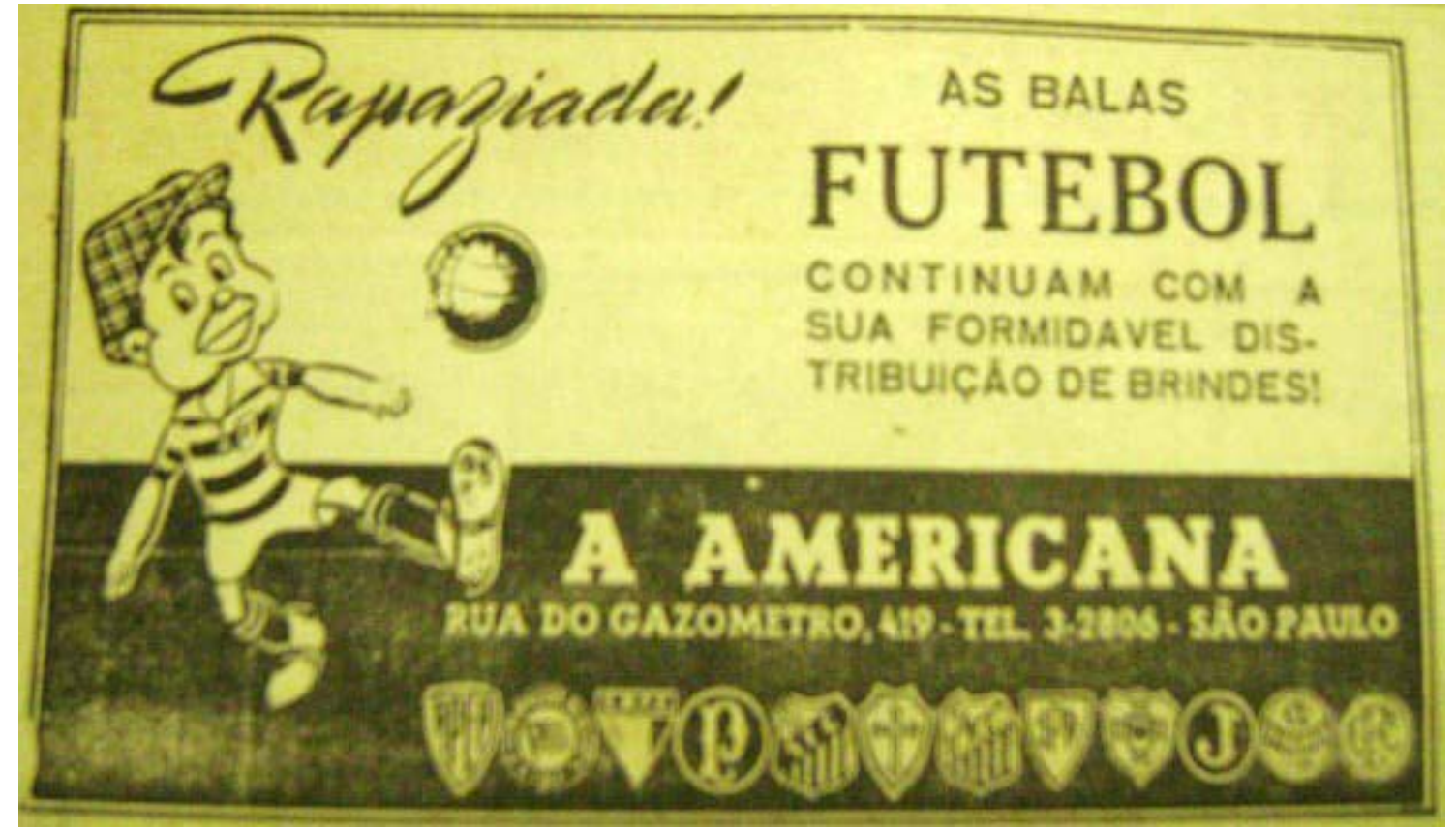

No anúncio das balas, o futebol foi utlizado como meio de propaganda concedendo, inclusive, o nome ao produto. Na peça publicitária encontram-se escudos dos príncipais clubes paulistas juntamente com o local onde as balas são vendidas. A figura do jogador de futebol não representa um clube específico, mas traz as características de um profissional da bola. Gazeta Esportiva, 29 de junho de 1942, p. 8.

Esses jornais esportivos continham inúmeras fotografias, sendo a grande maioria delas, de futebolistas, diretorias de clubes ou lances de partidas passadas. Outro elemento comum era o desenho de profissionais ligados ao futebol e dos mascotes dos principais clubes do país ${ }^{276}$.

\footnotetext{
${ }^{276}$ Em sua análise sobre a imprensa brasileira, Capelato destacou o estilo de apresentação dos jornais como uma ferramenta para conseguir seduzir o seu público alvo. Para a historiadora, os jornais elitistas teriam a apresentação mais sóbria (como se precebe nos periódicos Correio Paulistano, Jornal do Comércio e Gazeta de Notícias), enquanto os periódicos voltados aos setores populares traziam em suas páginas uma grande quantidade de ilustrações, títulos espetaculares, esportes, crime, horror e folhetins (apresentação que lembra a presente na Gazeta Esportiva e no Jornal dos Sports). CAPELATO, Maria Helena Rolim. Op. cit., p. 15.
} 


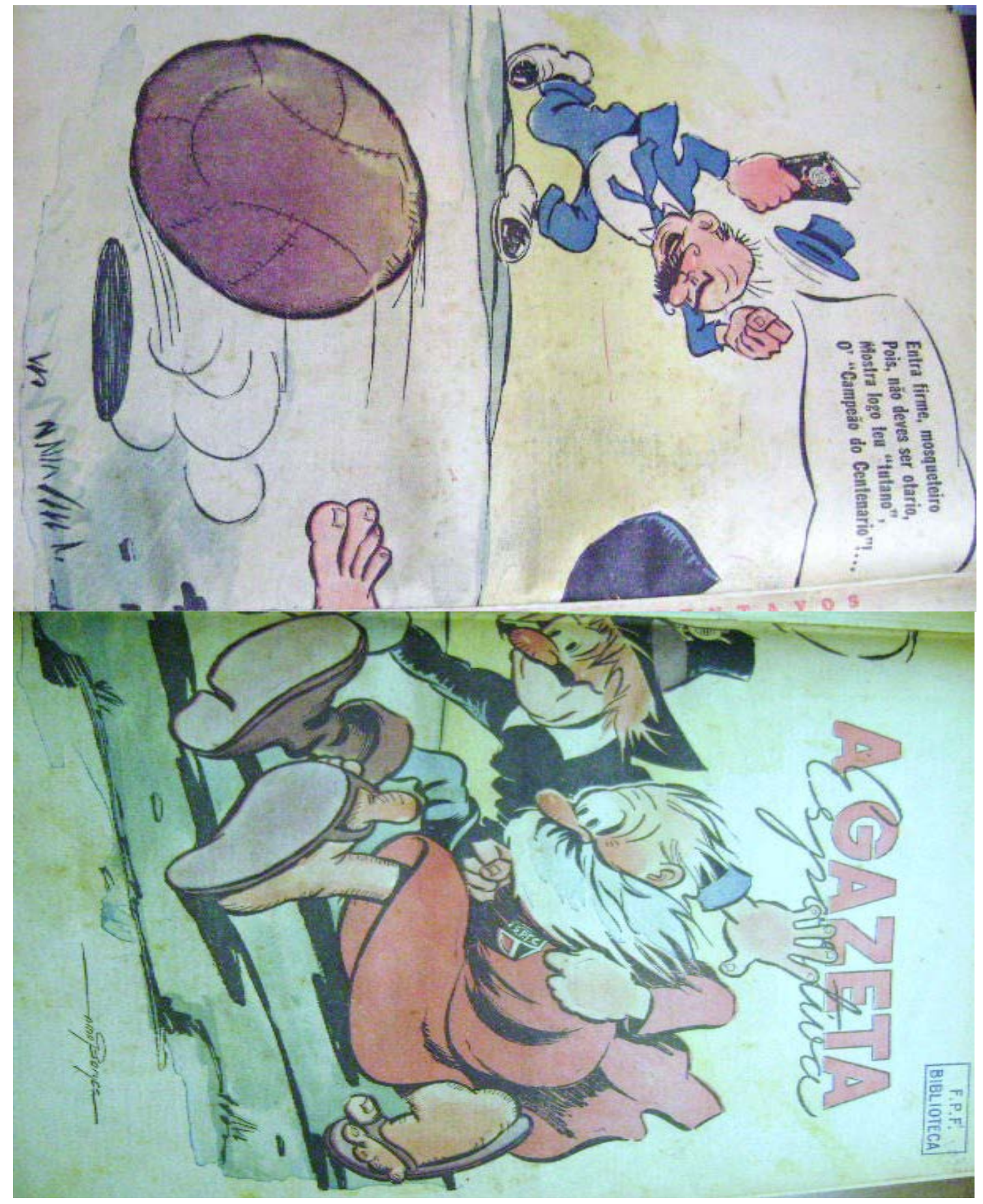

Ao analisar o desenho dos mascotes do Corinthians e do São Paulo na corrida pelo primeiro lugar do Campeonato Paulista de Futebol, salienta-se o fato desses símbolos clubísticos jamais serem negros: apesar de o futebol ser considerado um esporte popular, ele expressa nossa própria identidade nacional, ou seja, os valores impostos pela ideologia dominante e aceitos pela massa como elementos intrínsecos à sociedade. Além disso, percebe-se o elitismo presente no futebol profissional pela fala e vestimenta do torcedor corinthiano que, pela presença da cartola pode representar um dirigente do clube alvi-negro. O fato de a ilustração ser colorida, a evocação de uma identidade inventada como sendo própria do clube e a presença do epíteto "Campeão do Centenário” corroboram para caracterizar esse periódico como popular. Gazeta Esportiva, 01 de julho de 1944, p. 1. 


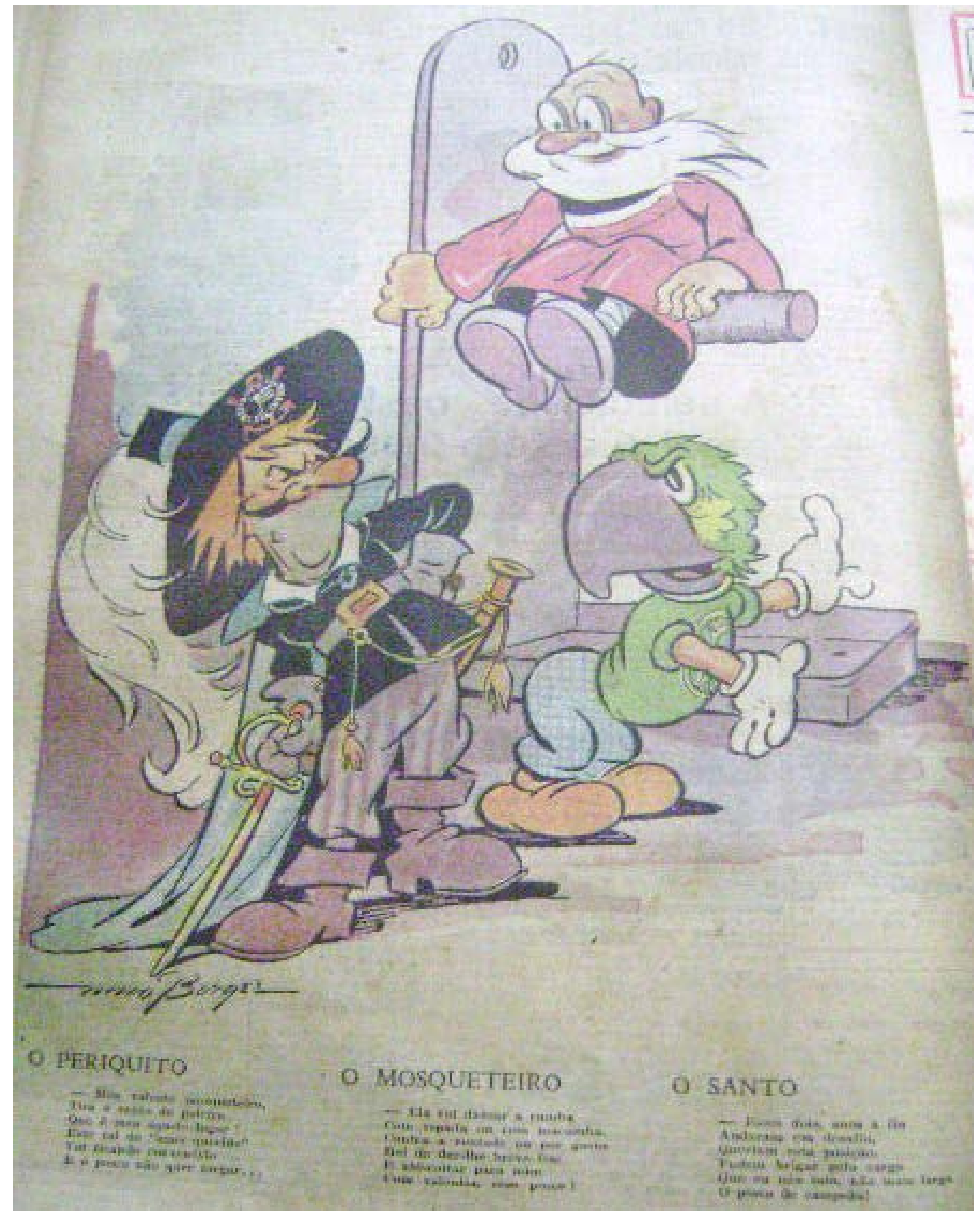

O desenho demonstra a posição dos três maiores clubes de São Paulo no campeonato regional por seus mascotes: o periquito, do Palmeiras; o mosqueteiro, do Corinthians, e o Santo, do São Paulo. Interessante notar que o mascote do São Paulo, clube criado para representar os interesses da classe dirigente do estado, não é aquele que mais lembra o bandeirante paulista, símbolo da tradição paulista. A presença de animais como símbolos de clubes futebolísticos foi analisada por Damo como "totemismo moderno", ou seja, símbolos que remetem aos fiéis uma determinada característica do clube, sendo essa capaz de ligá-los aos demais pertencentes dessa comunidade de sentimento imagianada. DAMO, Arlei Sander. Op. cit., p. 55. Desenho publicado em Gazeta Esportiva, 05 de maio de 1945, p. 16. 


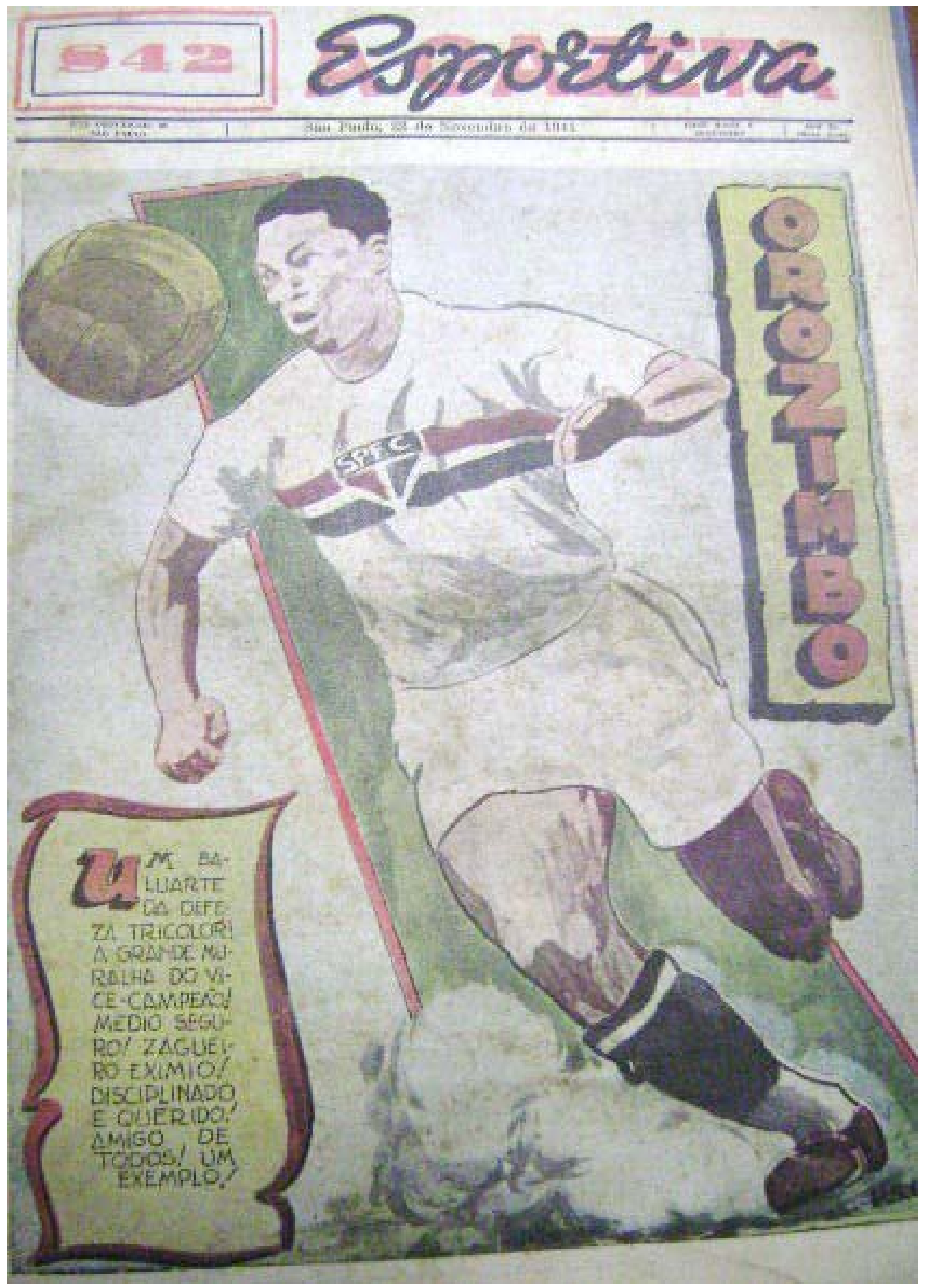

O texto publicado com o desenho de Orozimbo destacou como sendo as características exemplares do jogador do São Paulo Futebol Clube sua disciplina e senso de coletividade - valores afins com o projeto estadonovista de nação. Vale destacar a posição do jogador digno da capa e elogios do jornal: zagueiro. Gazeta Esportiva, 22 de novembro de 1941, p. 1. 
As notícias sobre a principal partida da rodada tinham, normalmente, sua chamada na capa e o texto sobre o desenrolar do jogo tinha um grande espaço no interior do jornal. Elas eram bem detalhadas e minunciosas, como se houvesse a necessidade de fazer o leitor criar um filme em sua mente sobre a partida, lance a lance $^{277}$.

Os combates de menor importância do campeonato eram noticiados em menos linhas, mas raramente faltavam informações sobre eles. O futebol praticado em ligas amadoras, nas fábricas, no interior dos estados de publicação dos jornais, o futebol feminino e de outros estados e países eram contemplados em pequenas notas na Gazeta Esportiva e no Jornal dos Sports.

Os leitores eram constantemente chamados para participar das publicações, pelo envio de cartas para a redação, participando dos concursos ou bolsas de apostas, nas seções em que eram ensinadas algumas regras futebolísticas e por meio da divulgação de manchetes pedindo auxílio para determinado clube, avisando sobre as reuniões e as próximas festas que aconteceriam nesses locais ${ }^{278}$.

\footnotetext{
277 José Carlos Marque destacou essa característica presente nas reportagens esportivas ao analisar a notícia publicada em 1903, entre Mackenzie 0 x 0 Paulistano. Além desse elemento, o autor ressalvou o uso exagerado da língua inglesa no jornalismo esportivo. Ambos os elementos ainda estavam presentes nos jornais publicados durante o Estado Novo. MARQUES, José Carlos. Op. cit., p. 74.

${ }^{278}$ Na seção denominda "Consultas”, onde os leitores perguntavam sobre dados estatísticos dos jogos, e no espaço denominado "Os que surgem" em que anunciava clubes recém fundados, ocorria um maior contato entre a Gazeta Esportiva e seus leitores. NEGREIROS, Plínio José Labriola de Campos. Op. cit., p. 81.
} 


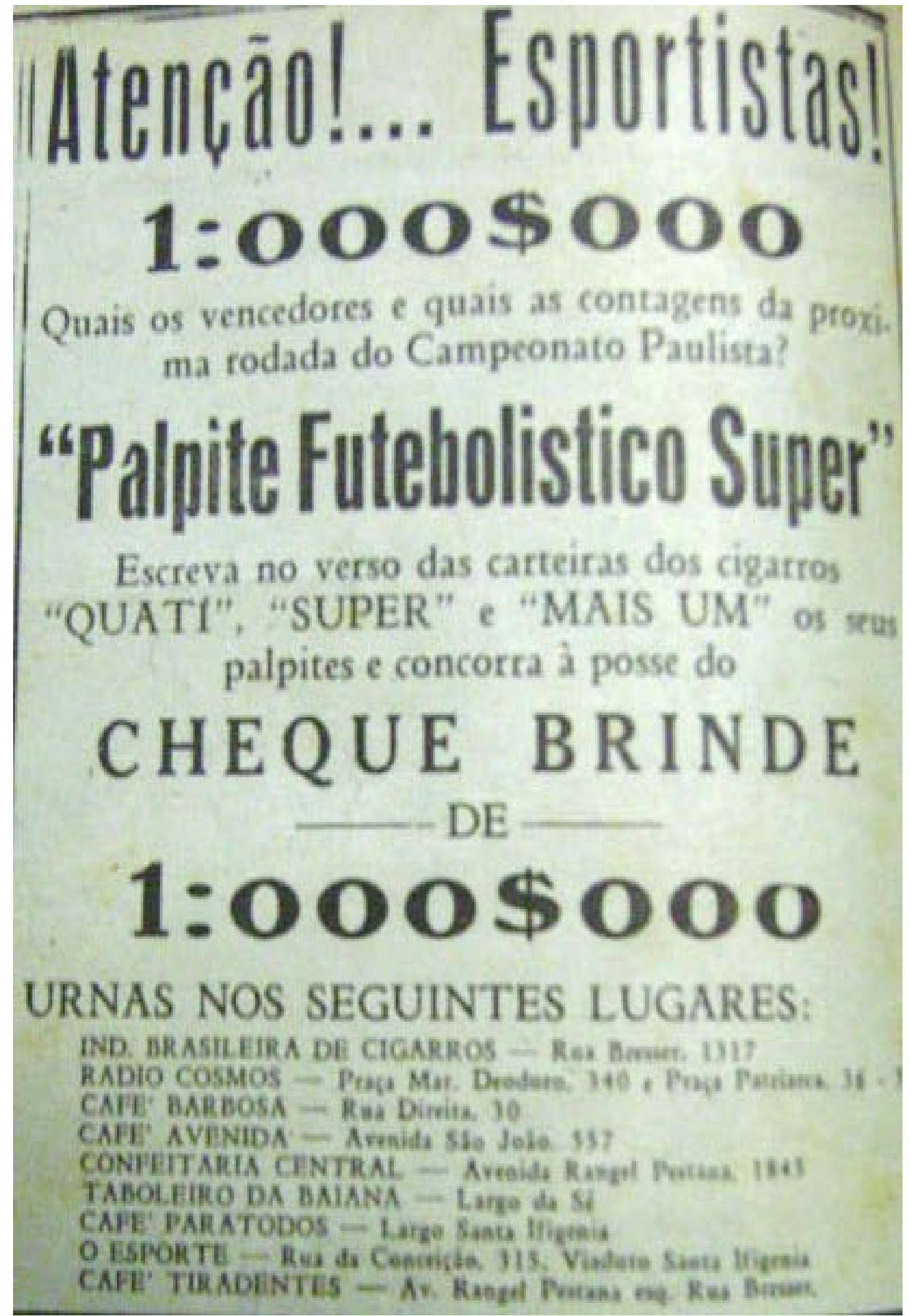

Chamada de bolão futebolístico vinculado à propaganda dos cigarros Quatí, Super e Mais um. Essas bolsas de apostas eram uma forma de diminuir a distância entre o jornal e seus leitores torcedores. Gazeta Esportiva, 22 de junho de 1942, p. 8. 


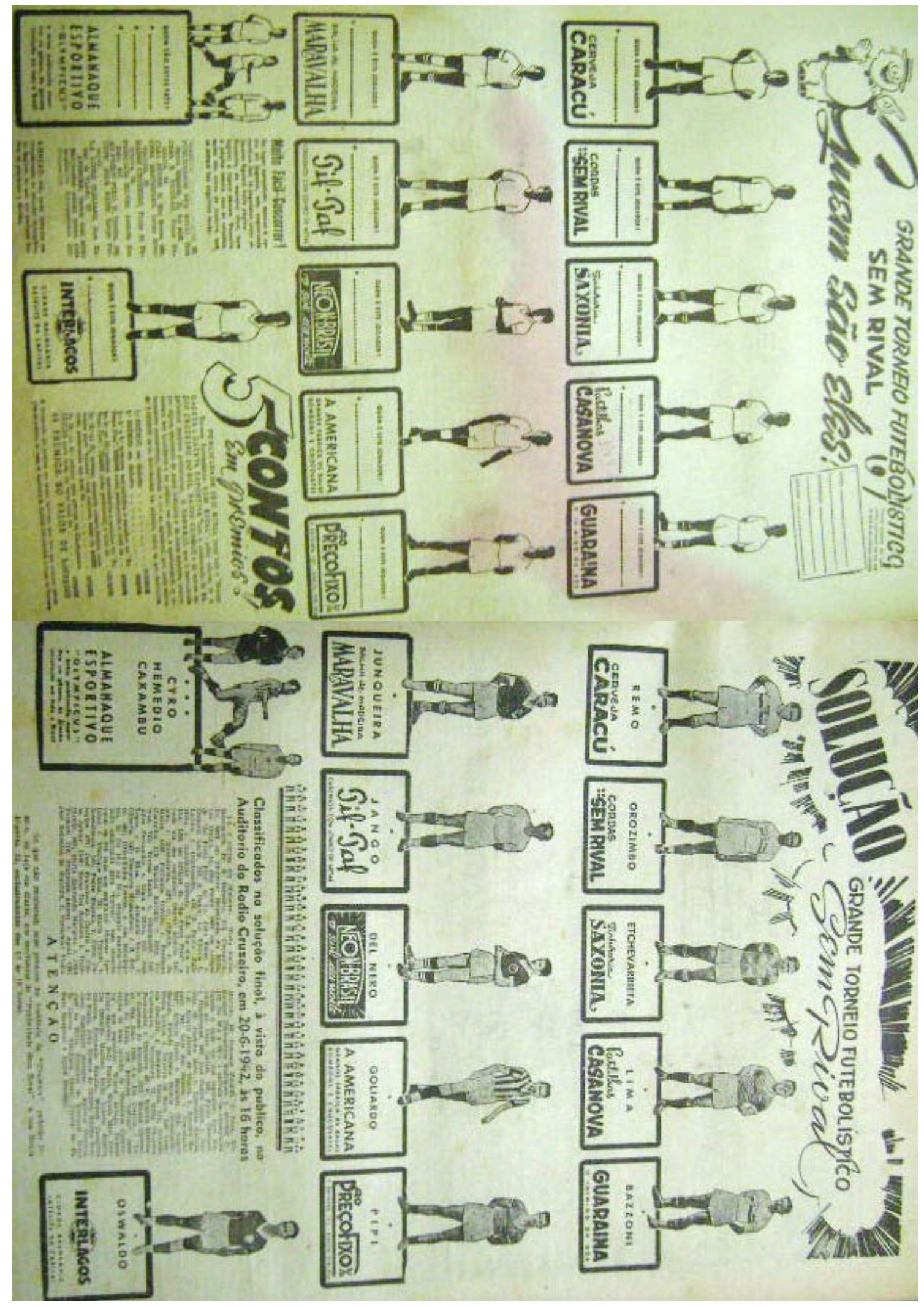

Concurso promovido pelo jornal para os leitores descobrirem os nomes dos jogadores desenhados em troca de um prêmio em dinheiro. Primeira edição só com os desenhos em Gazeta Esportiva, 26 de janeiro de 1942, p. 13. Segunda edição com a resposta do enigma, em Gazeta Esportiva, 22 de junho de 1942, p. 5. 


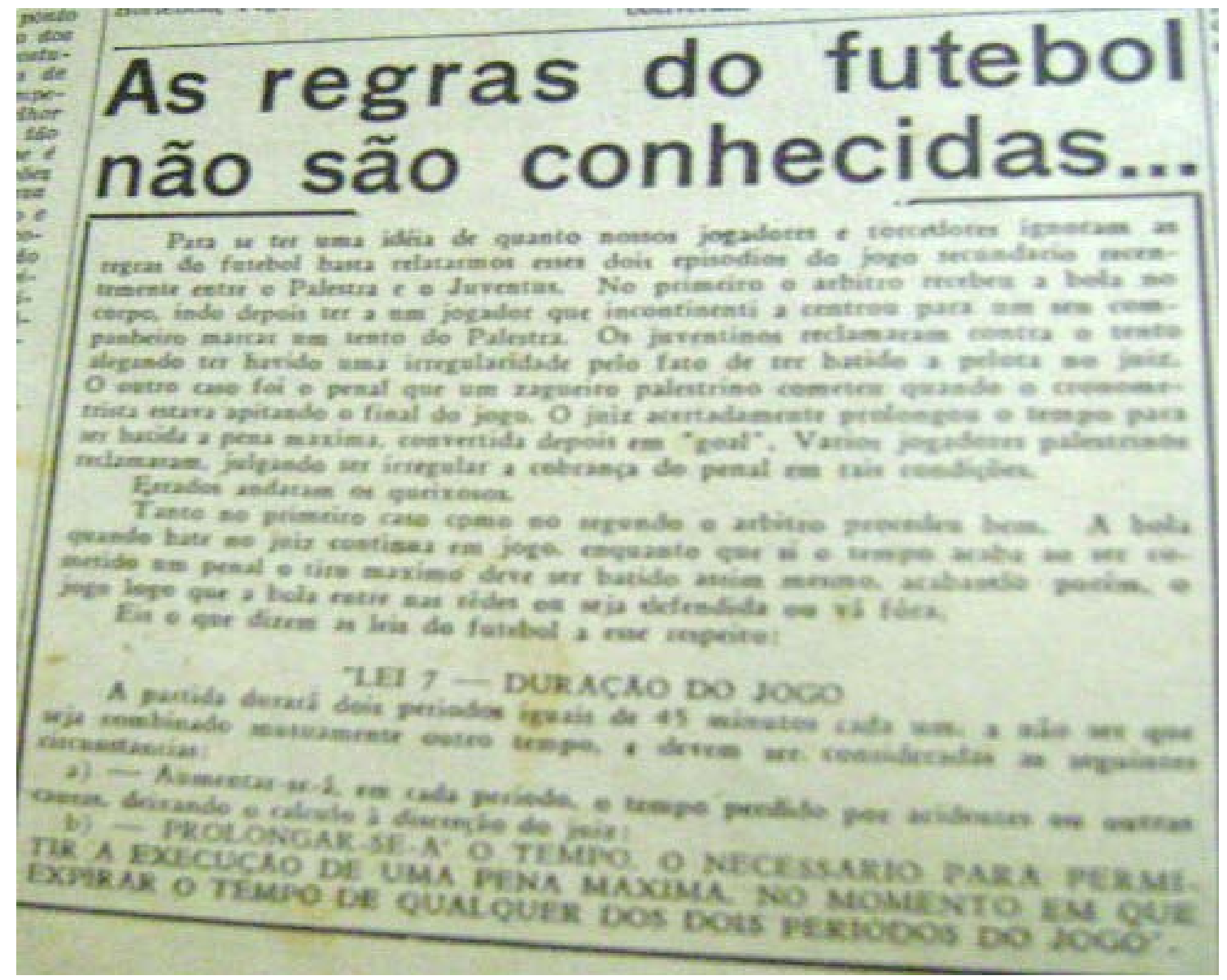

Reportagem esclarecendo a regra sobre o tempo de duração da partida. Gazeta Esportiva, 31 de agosto de 1940, p, 2. Para Mário Filho, o fato de os jogadores brasileiros desconhecerem as regras e não participarem de muitos jogos internacionais fora do continente, fazia com que os brasileiros empregassem mais a violência dentro de campo. ANTUNES, Fátima Martin Rodrigues Ferreira. Op. cit., pp. 119-120.

\section{S. E. Palestra Italia Auxilie a construçảo de nossa piscina. fumando "PALESTRA".}

Nota pedindo doações para a construção da piscina no Palestra Itália. Além de aproximar o leitor do jornal, tais notas criavam vínculos entre os clubes e o periódico que, no limite, acabavam em trocas de favores. Gazeta Esportiva, 19 de fevereiro de 1940, p. 4. 
Ao comentar os diferentes modos de jogar futebol como o jogo amador praticado nas fábricas e o esporte profissional, as notícias publicadas na Gazeta Esportiva agregavam torcedores de diferentes localidades em torno de um clube em comum:

\begin{abstract}
"Para o morador de um bairro popular, o jornal de Cásper Líbero era o periódico ideal. Para quem acompanhava o futebol, esperava-se uma publicação ágil, especializada e muito envolvida com o futebol como com outros esportes. Para essas pessoas, A Gazeta era uma referência, até porque o cotidiano do bairro também era encontrável nas páginas daquele jornal” 279
\end{abstract}

Desse modo, ao tratar o leitor a priori como um torcedor, a Gazeta Esportiva e o Jornal dos Sports criavam um forte vínculo com grande parcela da população, pois mesmo aqueles não alfabetizados ou sem condições financeiras de comprar diariamente as publicações desses periódicos acompanhavam as polêmicas e as opiniões de seus jornalistas sobre o ritual futebolístico cotidianamente vivenciado por eles, como massa torcedora $^{280}$.

Mesmo durante os períodos sem atividade futebolística, os jornais continuavam seus relacionamentos com os torcedores por meio de outras atividades culturais, como o carnaval. Além de manter os laços estreitados com a massa, essa mudança de foco permitia que os jornais especializados em esportes continuassem funcionando nos períodos sem futebol e o Estado não parasse de exercer seu controle social com discursos publicados pela imprensa:

\footnotetext{
${ }^{279}$ NEGREIROS, Plínio José Labriola de Campos. Op. cit., p. 61.

${ }^{280}$ A Gazeta Esportiva voltou a trazer em suas edições, desde 1942, quando o Brasil entrou à guerra e o regime começou a perder força, a seção "O que os leitores nos escrevem” na qual as cartas dos leitores eram publicadas na íntegra e traziam declarações de amor a seus clubes, críticas e sugestões para melhorar o futebol praticado no país.
} 
"Isso [a falta de eventos esportivos] fez com que muitas iniciativas não vingassem e diversos jornais tivessem que fechar suas redações, uma vez que o número de eventos ainda era insuficiente para se justificar um veículo exclusivo para o esporte. Até Mário Filho padeceu desse problema, tendo que recorrer a alternativas inusitadas para, por exemplo, não fechar o Mundo Esportivo, jornal que ele havia comprado em 1931. Diante da falta do que noticiar no mês de fevereiro de 1932, e atendendo a sugestão de um de seus repórteres, ele estabeleceu, divulgou e realizou o primeiro desfile das Escolas de Samba do Rio de Janeiro, prática que seria absorvida no ano seguinte pelo jornal $O$ Globo (para o qual Mário Filho também trabalhava), e que viria a se consubstanciar no discurso que cohecemos até hoje” ${ }^{281}$.

As opiniões e os ideais dos jornalistas raramente apareciam como crônicas, pois essas eram censuradas pelo Estado autoritário. Nesse sentido, apenas no último ano do Estado Novo, quando o regime já estava enfraquecido, apareceram seções em que os jornalistas davam suas opiniões de um modo mais contundente na Gazeta Esportiva. O Jornal dos Sports iniciou seu espaço de crônicas esportivas em 1943, denominado "Uma pedrinha na shooteira”.

Sobre a presença das crônicas nos jornais brasileiros e sua especificidade ao demonstrar a opinião do jornalista sobre o assunto, Fátima Antunes escreveu:

\begin{abstract}
“A crônica, enquanto gênero literário teve seu desenvolvimento no Brasil vinculado aos jornais cariocas da segunda metade do século XIX. Ela não apareceu propriamente com o jornal, mas somente quando este se tornou diário, com grande tiragem e preço relativamente acessível. A princípio, tratava-se de uma coluna de comentários e se chamava folhetim: ficava no rodapé e trazia reflexões e opniões sobre os assuntos do dia. Com o tempo, a intenção de divertir sobrepujou a de informar e comentar...
\end{abstract}

Na crônica, a notícia é tomada como pretexto para um discurso que transcende a própria notícia com o objetivo de informar, onde o autor expõe seus argumentos, interpretando fatos e acontecimentos. Trata-se, na verdade de um ensaio" ${ }^{282}$.

Desse modo, para constatar as concepções dos jornalistas sobre a prática

futebolística, procurou-se analisar as brechas existentes em seus escritos nas quais escapavam da censura suas opiniões pessoais, a importância concedida por ele a um

\footnotetext{
${ }^{281}$ MARQUES, José Carlos. Op. cit., p. 84.

${ }^{282}$ ANTUNES, Fátima Martin Rodrigues Ferreira. Op. cit., p. 27.
} 
determinado evento e as publicações realizadas por esses formadores de opiniões fora dos jornais.

Dois grandes jornalistas destacaram-se na crônica esportiva: Thomas Mazzoni, editor-chefe da Gazeta Esportiva e Mário Rodrigues Filho, diretor do Jornal dos Sports. A atuação de ambos foi fundamental para divulgar o futebol à multidão de aficcionados e, por consequência, fazer desse esporte um dos principais elementos de propagação dos ideais do regime.

Ao ressaltar a festa presente no ritual futebolístico, esses jornalistas representavam o futebol como um carnaval diário na sociedade, concretizando esse esporte como espetáculo e acentuando o seu aspecto mobilizador de massas. 


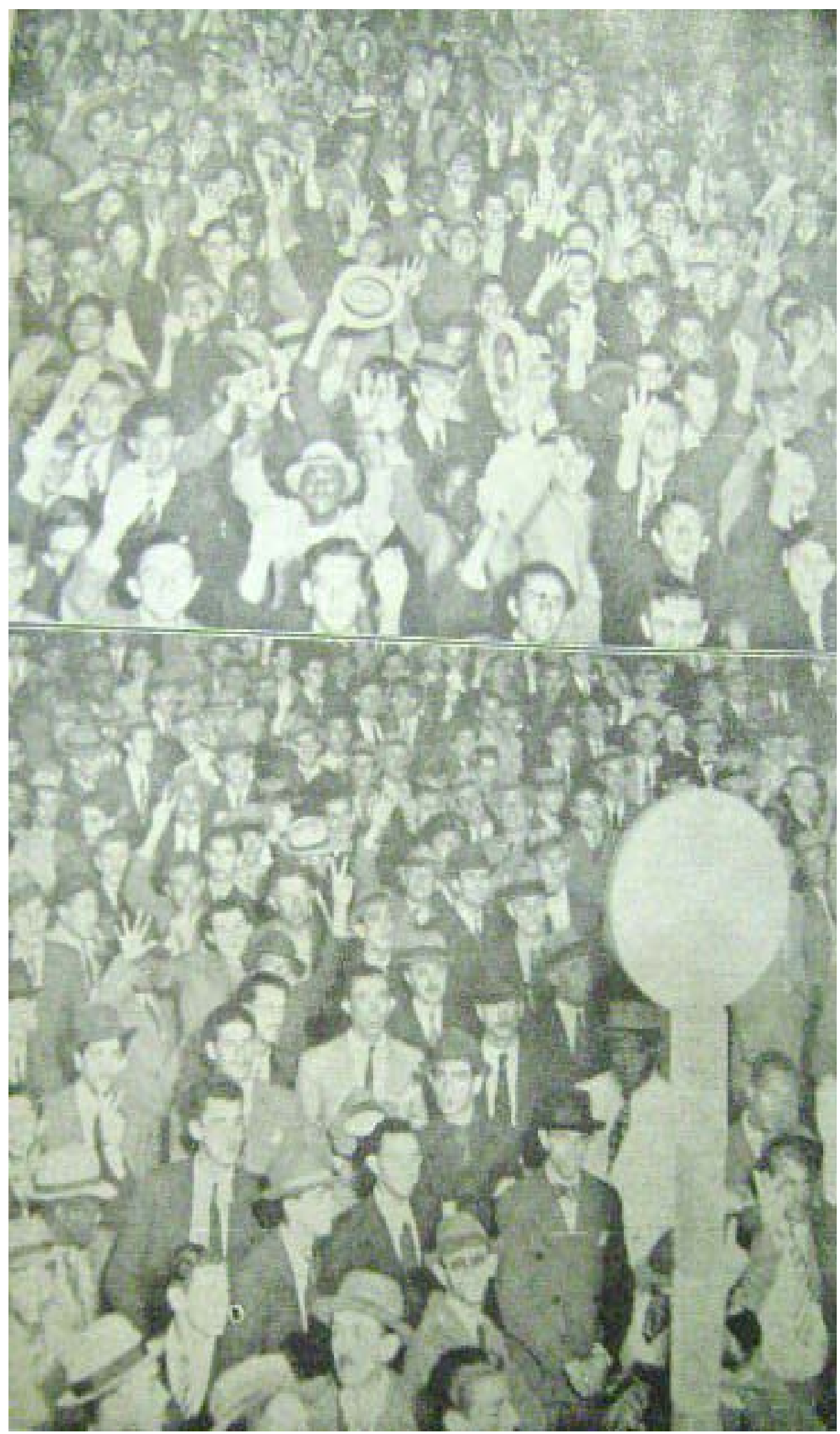

Torcida paulista em frente ao prédio da Gazeta durante a irradiação do jogo América Mineiro versus Palestra Itália. Na foto percebe-se a concretização do futebol como um esporte de massa e, em primeiro plano, voltado ao público masculino. Gazeta Esportiva, 15 de junho de 1938, p. 11. 


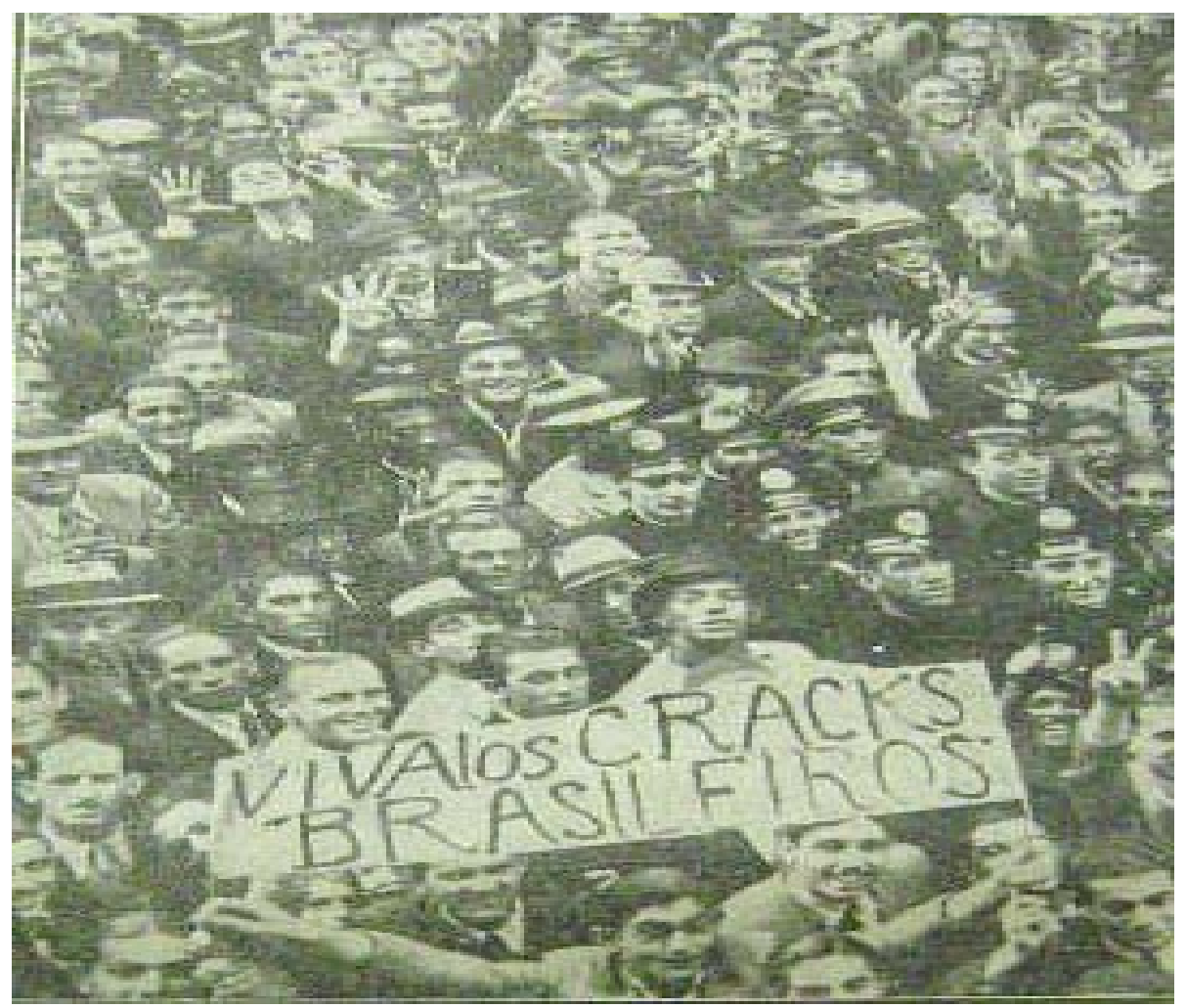

Multidão ouvindo a irradiação da partida Brasil versus Argentina disputada pela Copa Roca, em frente à Gazeta. Na imagem nota-se a presença policial garantindo a ordem. Gazeta Esportiva, 23 de janeiro de 1939, p. 6.

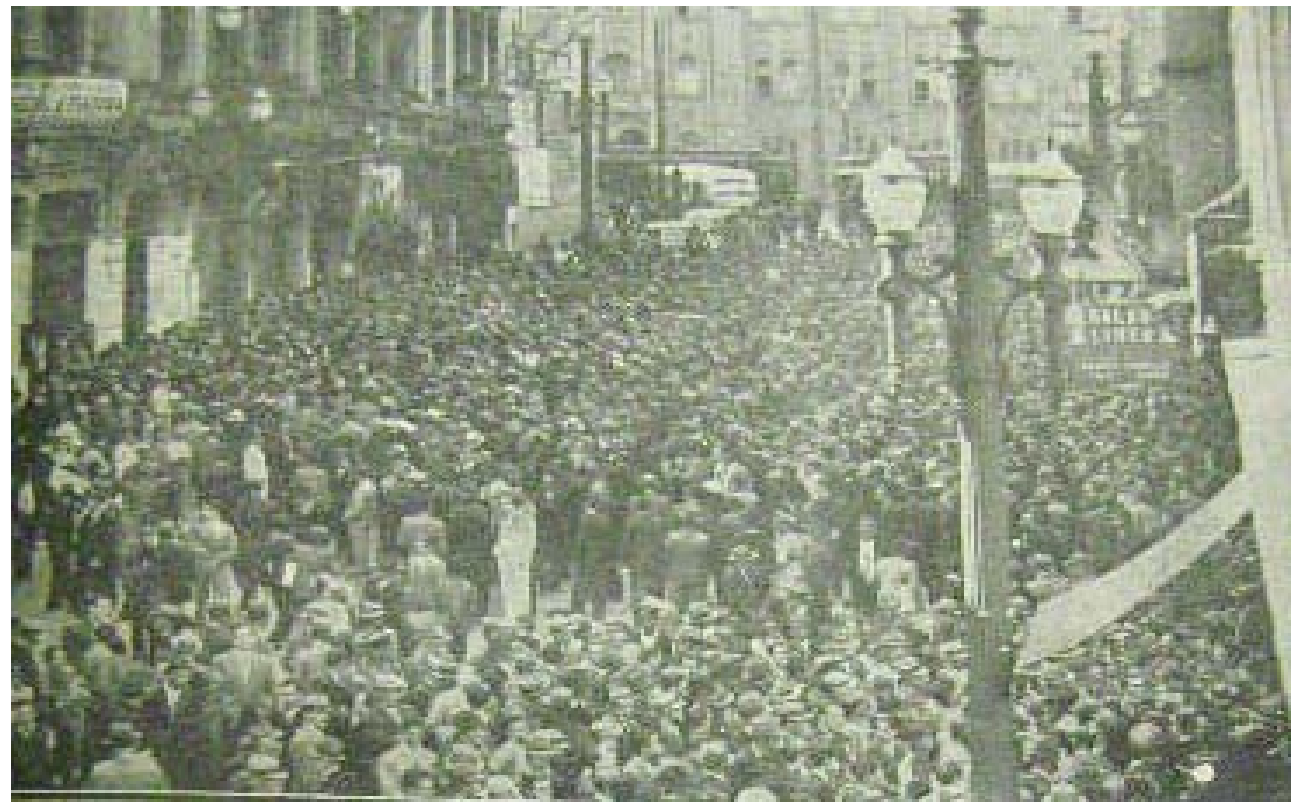

Foto panorâmica da rua em frente ao prédio da Gazeta durante a irradiação dos jogos da seleção no Mundial de Futebol, em 1938. Gazeta Esportiva, 15 de junho de 1938, p. 11. 


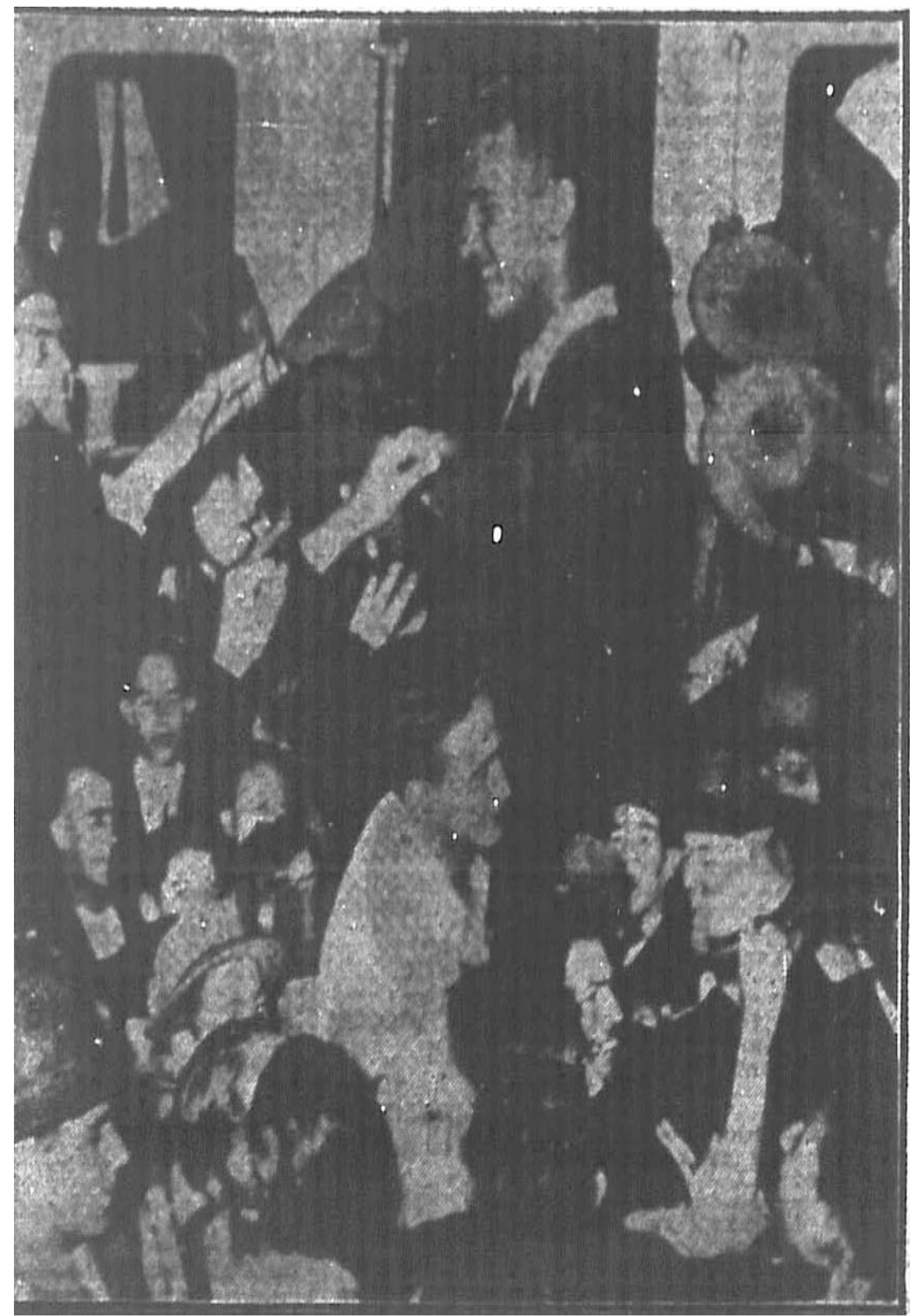

Montagem com duas fotos em planos diferentes nas quais os jogadores paulistas aparecem sendo recebidos e assediados pela torcida após a disputa final do Campeonato Brasileiro. Correio Paulistano, 19 de dezembro de 1942, p.8. 


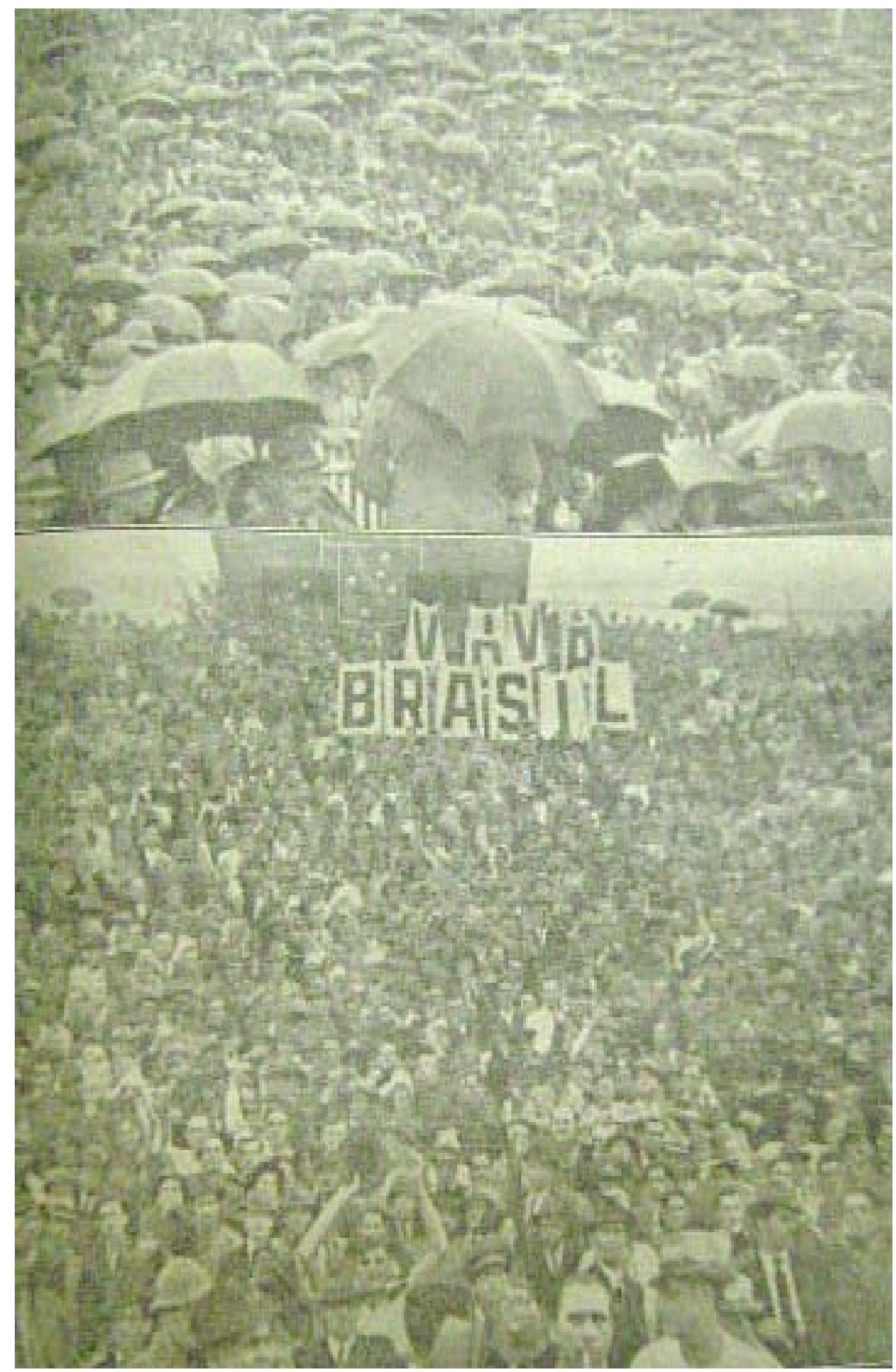

Foto da "avalanche humana" formada por torcedores durante a Copa Roca. Gazeta Esportiva, 19 de fevereiro de 1940, p. 11. 
A presença das torcidas uniformizadas constitui um bom exemplo para ilustrar o caráter mobilizador do futebol e sua espetacularização ${ }^{283}$. Ao destacar os chefes das torcidas uniformizadas, a Gazeta Esportiva realizava a mediação entre esse tipo de torcedores e a massa de aficcionados. Em julho de 1943, a Gazeta Esportiva trouxe a seguinte notícia sobre essas torcidas:

“... Soubemos que a diretoria do alvi-verde resolveu suspender temporariamente as atividades da 'torcida' uniformizada do Campeonato de 42 por falta de garantias. Mas, como? Sim, por falta de garantias! Declaram-nos os informantes que de uns jogos para cá, vários indivíduos se colocam em redor da 'torcida', ou então na frente e passam a insultar seus componentes com palavrões, ou então dirigem gracejos indesejáveis às moças que também vestem o uniforme alvi-verde, Disseram-nos ainda, que no prélio Corinthians x Palmeiras, realizado em disputa da Taça 'Cidade de São Paulo' um dos chefes de torcida pretendeu repreender um desses indesejáveis e quase foi vítima da agressão por parte desse mesmo indivíduo. (...) As torcidas uniformizadas vieram dar um colorido todo especial a esta fase de ouro que atravessa o nosso futebol, sendo até mesmo inacreditável que o premio que estão a receber por terem feito isso seja o que recebeu o Palmeiras. As nossas autoridades policiais precisam tomar enérgicas providencias no sentido de protegerem as nossas uniformizadas, colocando à disposição das mesmas alguns policiais. Estes deverão colocar-se ao lado dos cordões de isolamento, a fim de agirem quando se tornar necessário. Cremos que dessa forma, os 'valentes' não se atreverão tentar destruir uma conquista grandiosidade nosso futebol - AS TORCIDAS UNIFORMIZADAS” ${ }^{284}$.

O primeiro ponto a se destacar no trecho acima consiste na exaltação da uniformaização das torcidas, em afinidade com a uniformização social proposta pelo governo. Essa estética na qual imperava a figura de um grupo unido e disciplinado compunha a ideologia estadonovista e auxiliava na ordenação social e construção de uma nação ordenada e unida.

Além disso, a notícia demonstra o caráter mobilizador do futebol pela

\footnotetext{
${ }^{283} \mathrm{O}$ aspecto de ritual misto no futebol encontra-se na própria atuação das torcidas uniformizadas. Ao mesmo tempo em que essas torcidas se apresentavam como verdadeiros blocos carnavalescos, elas agiam de acordo com os ideais burocráticos de ordem, unidade e harmonia propagado pelo Estado Novo. As torcidas uniformizadas eram formadas por sócios dos clubes, em sua maioria, provientes da classe dominante, diferentemente das torcidas organizadas de hoje, formadas por torcedores dos clubes que se associam em torno dessas entidades regulamentadas, o que faz esse grupo ser mais fluido e dinâmico que o do passado.

${ }^{284}$ Gazeta Esportiva,12 de julho de 1943, p. 7.
} 
organização das torcidas uniformizadas e da massa popular unida para afrontar os membros da primeira. A festa e o espetáculo futebolístico presentes na arquibancada e defendidos pelo cronista encontram-se afim com os princípios do regime, pois estavam baseados no elitismo, disciplina e coletivismo.

Percebe-se que a coletividade displinada era formada pelos grupos sociais privelegiados economicamente pertencentes aso setores elitistas, pois eram as mulheres e os demais sócios dos clubes que compunham as torcidas uniformizadas. Assim, o conflito entre diferentes classes sociais aparecia nas arquibancadas de futebol, pois juntamente com os torcedores uniformizados afinados com os ideais estadonovistas, participavam do jogo de futebol os indivíduos pertencentes aos setores populares da sociedade.

A presença do torcedor pobre era encarada como hostil e não civilizada pelo cronista, fazendo-o pedir a intervenção do Estado via aparato policial para conter o populacho e salvaguardar os demais torcedores. Desse mesmo modo o Estado Novo tentava controlar essa tensa relação na sociedade, disciplinando a massa popular com a propagação ideológica e, em última instância, pelo uso do aparato coercitivo. Sobre essa necessidade de preservar a ordem e a disciplina almejada por torcedores e cronistas, Plínio Negreiros escreveu:

\footnotetext{
"Por outro lado, quando a imprensa, como também torcedores, começa a chamar pela presença policial nos estádios de futebol, está colocando esse esporte como incapaz de se auto-organizar. Assim, o esporte mais popular da cidade e do país necessitava de um tentáculo estatal: a repressão e intimidação pela força policial - Ou, mais uma vez, o medo das multidões; estas precisavam ser acompanhadas de perto" ${ }^{285}$.
}

${ }^{285}$ NEGREIROS, Plínio José Labriola de Campos. Op. cit., p. 73. 


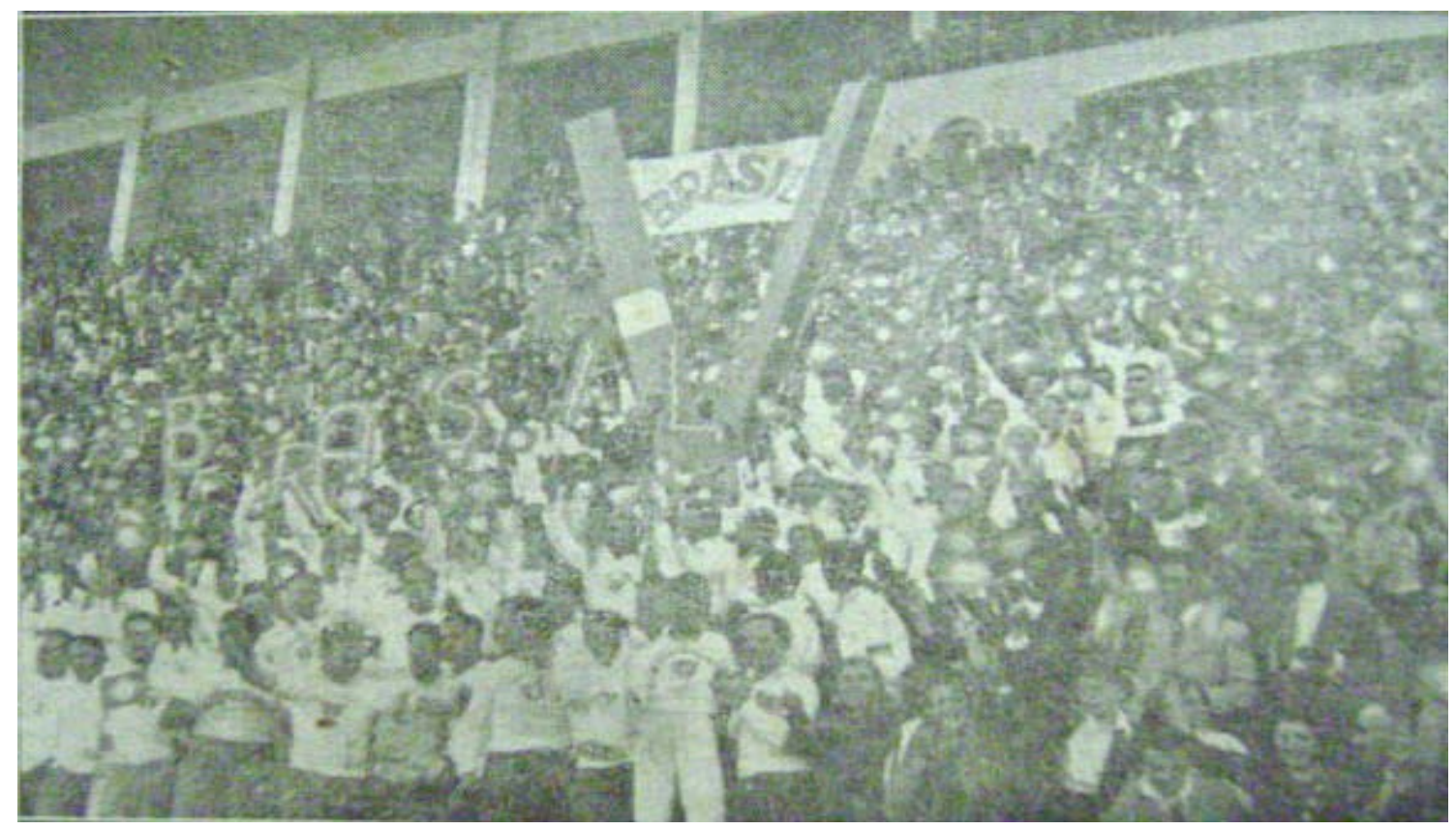

Torcida uniformizada do tricolor paulista em clima de carnaval durante o Majestoso (São Paulo versus Corinthians). Gazeta Esportiva, 31 de agosto de 1942, p. 6.

A relação construída entre o jornalista e o leitor extrapolava o âmbito do jornal,

sendo ambos colocados como torcedores cuja atuação era fundamental para o sucesso

de seus clubes:

“... Os interesses dos paulistas em jogo não são apenas de reduzir o número de jogos e sim de garantirmos - com justiça, com critério, com imparcialidade - para a nossa seleção igualdade de direitos em decidir o título com os cariocas. (...) Todos se preocupam somente com o número de partidas, mas ninguém liga ao crônico problema da desigualdade que influe decisivamente na sorte do título. (...) Se o título fosse decidido um ano aqui e outro no Rio, ou seja, com o critério do rodízio no local do terceiro ou do quinto jogo decisivo, o balanço do campeonato entre paulistas e cariocas não seria o qual é, inferior aos paulistas, obrigados de 1923 até 1944, a disputar ' 16 vezes' a partida 'finalissima' no Rio, enquanto que os cariocas apenas se submeteram a essa prova penosa somente ‘3 vezes’! (...) Existe, dirão, o sorteio. Este é o que indica - quase sempre - o local decisivo. E sorteio, é a sorte que favorece, caprichosamente, os cariocas. Por isso mesmo nós podemos estar sujeitos sempre a decidir o título pelo azar? Não serve, porque existem outros critérios esportivos, universalmente adotados..." 286 .

Como um verdadeiro torcedor, o jornalista paulista expressou a sua indignação

${ }^{286}$ Gazeta Esportiva,7 de abril de 1945, p. 7. 
sobre o critério para escolher o local da disputa final do Campeonato Brasileiro e sugeriu a implementação de rodízio das sedes finais em substituição ao sorteio. Os jornalistas esportivos comumente se expressavam dessa maneira direta e apaixonada. Por meio de um discurso marcado pela ironia e calcado no sentimento regionalista, engendrava-se um campo de disputa em que a perpetuação de uma imagem poderosa de um estado ou clube futebolístico estava em jogo.

Nos jornais esportivos a linguagem presente nas matérias era igual àquela falada pelos torcedores; os nomes dos clubes de futebol eram escritos conforme se pronunciava nas arquibancadas e os epítetos formadores da identidade clubística eram constantemente trabalhados para popularizar o periódico e, assim, fazer com que suas mensagens chegassem a um maior número de torcedores - leitores.

Foram grifados alguns exemplos de linguagem pronunciadas pelos torcedores e publicadas nos jornais, a fim de criar uma empatia maior com os aficcionados:

\begin{abstract}
"Sim. Devemos um prélio de gratidão ao futebol da Guanabara. Devemos agradecer-lhes pelo impulso que lhe demos há alguns anos atrás com Tim, Batatais, Hercules, Machado, Romeu, etc. Devemos agradecer-lhes pelo domínio que sempre tiveram nas secretarias do futebol brasileiro. Bela choradeira! ... quando o Fluminense sozinho tinha mais dinheiro que o Palmeiras, São Paulo e Corinthians, o tricolor carioca poderia ter levado, não um selecionado bandeirante, mas sim todos os cracks do nosso futebol: Caspite, foi pouco (...) Basta! Não precisamos dizer mais nada. As dores são agudas. O desespero é enorme e o pavor das cifras bandeirantes não tem limites... Não adianta lamurias. Pesa a balança notoriamente e daí o despeito destilado que se vê soltar a olhos vistos pellas trombetas da publicidade do futebol carioca" $^{287}$.
\end{abstract}

Essa influência da linguagem pronunciada pelos torcedores nas matérias de Mário Filho foi analisada por Fátima Antunes quando a historiadora destacou a entrevista que o jornalista carioca realizou com Marcos Mendonça, goleiro do Fluminense:

${ }^{287}$ Gazeta Esportiva, 10 de janeiro de 1944, p. 5. Grifos nossos. 
“A entrevista ocupava meia página; apresentava-se numa linguagem nova, simples e vibrante, lembrando a língua até então falada nas ruas e nas arquibancadas dos estádios de futebol, e que estreava no jornal, dando indícios de que a época dos acadêmicos estava chegando ao fim” ${ }^{288}$.

O processo de profissionalização do futebol foi ardentemente defendido por Mazzoni e Mário Filho. Para esses jornalistas, a profissionalização desse jogo era um elemento fundamental para a construção da nação, pois a sua prática envolvia coletivismo, disciplinarização do corpo e valorização da hierarquia. De acordo com Plínio Negreiros, a Gazeta Esportiva destacava os esportes profissionais em suas páginas como uma maneira de educar as massas nos moldes cívicos propostos pelo governo:

“A Gazeta preocupava-se com todos os esportes, destacando-se o futebol. Em relação ao grande debate dos anos 30, colocava-se a favor do profissionalismo, não apontando essa condição como geradora das dificuldades pelas quais o futebol passava (...) Para A Gazeta, o esporte enquanto fator de educação também era importante; e não só para os praticantes. $\mathrm{O}$ esporte deveria ser um espaço privelegiado de formação da população. Educar-se-iam praticantes e apreciadores dos esportes e das atividades físicas" ${ }^{289}$.

Além dessa função educadora, conforme destacou José Carlos Marques, a profissionalização do futebol não somente popularizou o jogo como aumentou a comercialização dos jornais esportivos e destacou seus profissionais:

"O percurso percorrido pelo futebol entre o amadorismo e o profissionalismo tem sua similaridade na trajetória da imprensa esportiva. Até o início da década de 40, o cronista esportivo ocupava a posição mais baixa na hierarquia dos jornais, e o futebol mantinha discreto destaque na imprensa escrita. Com a atuação de Mário Filho, houve a valorização do métier do analista e do repórter esportivo, a partir de seu trabalho com a produção do evento, e este a fornecer elementos para a atuação do homem da imprensa esportiva” ${ }^{290}$.

\footnotetext{
${ }^{288}$ ANTUNES, Fátima Martin Rodrigues Ferreira. Op. cit., p. 103.

${ }^{289}$ NEGREIROS, Plínio José Labriola de Campos. Op. cit., p. 57.

${ }^{290}$ MARQUES, José Carlos. Op. cit., p. 17
} 
Na concepção de futebol profissional engendrada por ambos os jornalistas, a popularização do esporte não estava descolada dos princípios elitistas presentes no jogo desde a sua época amadora. Os jornalisas Mazzoni e Mário Filho acompanhavam a ideologia estadonovista ao valorizarem e transmitirem à massa os ideais elitistas, conservadores, nacionais e autoritários presentes no governo.

Apesar de tentar popularizar o periódico utilizando uma linguagem simples e aproximada daquela pertencente à massa, a permanência dos princípios elitistas no futebol, após a sua profissionalização e popularização, pode ser demonstrada pelo fato do nome do principal jornal esportivo do Rio de Janeiro, e da maioria de suas seções, serem grafados com estrangeirismos, tal como era feito quando o futebol era praticado pela elite inglesa ${ }^{291}$.

Outro exemplo da permanência elitista na concepção esportiva presente nos periódicos analisados consiste na notícia publicada na capa da Gazeta Esportiva, intitulada "Culto a Charles Miller”, na qual o mito de origem do futebol aparecia calcado no elitismo exemplificado pela figura do jovem estudante rico que voltou da Europa (continente símbolo da civilização) para implantar um elemento da modernidade burguesa em uma sociedade ainda arcaica:

\footnotetext{
“Comemoramos ontem o $40^{\circ}$ aniversário do $1^{\circ}$ Campeonato Paulista de Futebol. A efemeridade não é só paulista, mas brasileira. E relembrá-la, importa em recapitular a própria história do 'association' nacional, que nasceu em terras Piratininga. Jornal de larga tradição esportiva A GAZETA, como não podia deixar de ser, assinalando o acontecimento, oferece seu número de
}

\footnotetext{
291 Segue a relação das seções presentes do Jornal dos Sports, cujos nomes eram grafados com influência de línguas estrangeiras: "Basket-ball”, "Sports em Nictheroy”, “Catch-as catch-can”, "Bolão sportivo”, "Basketballers do Brasil”, "Sports na ALE", "Sports suburbanos", "Volleyball”, "Football dos clubs independentes”, “Sociaes Sportivas”, “Water-polo”, “Sports na Light”, “Sports aquáticos”, “Shoots... (de bobina)” e "Uma pedrinha na shooteira”.
} 
hoje aos futebolistas do passado e do presente, publicando orgulhosamente a ressurreição daqueles fatos a que S. Paulo [sic] está estritamente ligado como introdutor e pioneiro do futebol no Brasil”" ${ }^{292}$.

Nesse texto presente na capa da edição, o jornalista exaltou a importância do futebol paulista para o esporte nacional, pois teria sido ele o introdutor desse esporte no Brasil, pela mítica figura de Charles Miller. O desenvolvimento industrial e cafeeiro de São Paulo teria formado uma elite esclarecida que, ao voltar dos estudos na Europa, trouxe o elemento que seria a síntese da nacionalidade. Assim, ao ler o texto, pode-se fazer uma relação entre o nacionalismo brasileiro, o desenvolvimento econômico de São Paulo e a ilustração da elite paulista.

A matéria era composta por outras seis páginas presentes no interior da mesma edição, com a chamada "Quando e onde começou o futebol no Brasil”. O texto escrito por Mazzoni desenrolou-se com uma cronologia linear dos fatos no qual a história do futebol brasileiro foi apresentada pela história do futebol paulista.

Primeiramente, Mazzoni apresentou a prática futebolística indígena no período pré-colombiano contextualizando a sua chegada na América do Sul por intermédio de marinheiros ingleses que jogavam futebol no litoral. Em São Paulo e no Rio de Janeiro, esse esporte passou a ser praticado nos colégios e entre os trabalhadores estrangeiros que viviam no país.

A chegada de Miller com o material para o jogo e a difusão do futebol nos clubes de São Paulo quando partidas eram disputadas na chácara Dulley, foram os acontecimentos apresentados em seguida. O jornalista destacou que, enquanto São Paulo já tinha quatro clubes com departamentos de futebol, esse esporte ainda estava na fase embrionária no Rio de Janeiro.

\footnotetext{
${ }^{292}$ Gazeta Esportiva, 4 de maio de 1942, p.1.
} 
Em seguida Mazzoni descreveu o processo introdutório do futebol no Rio de Janeiro com Oscar Cox, e o início da unificação futebolística em São Paulo, coordenada por Antonio Casemiro da Costa que levou à formação do primeiro campeonato paulista de futebol.

Após comparar a iniciativa de Casemiro da Costa em dilatar as fronteiras futebolísticas propondo jogos interestaduais entre São Paulo e Rio de Janeiro como uma ação própria dos bandeirantes, Mazzoni contextualizou a formação dos principais clubes paulistas e o início do movimento em favor do profissionalismo no futebol, motivado pelo lucro conseguido nas bilheterias.

Finalizando a matéria, o jornalista destacou a força do futebol paulista destacando como exemplo da sua grandiosidade a construção de um estádio que superou todos os demais, o Pacaembu. Além disso, o jornalista colocou o povo paulista à disposição do governo para continuar trabalhando pelo engrandecimento da nação:

"Continuemos a trabalhar pela organização dos nossos esportes de colaboração com o governo (...) Isto tudo é necessário quando sabemos ser hoje acentuada a influência dos esportes na educação do homem e na sociedade!” ${ }^{293}$.

${ }^{293}$ Gazeta Esportiva, 04 de maio de 1942, p. 10. 


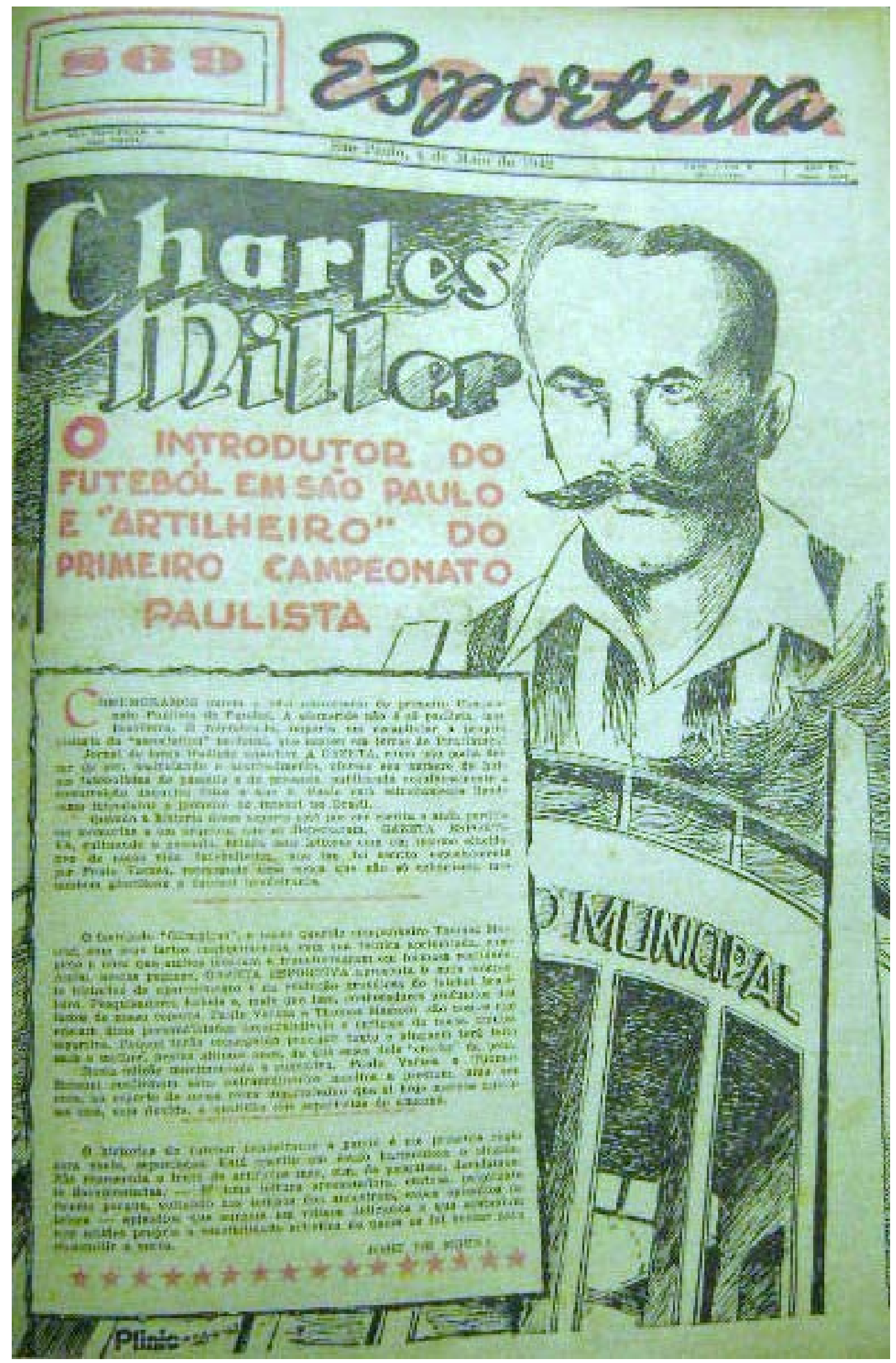

Capa trazendo a chamada da notícia sobre Charles Miller e a introdução do futebol no Brasil. Note-se a presença de dois símbolos do orgulho paulista, Miller e o Pacaembu, fazendo uma ligação do futebol praticado no passado com o jogado no presente. Gazeta Esportiva, 04 de maio de 1942, p. 1. 
Nos parâmetros elitistas do esporte, a violência intrínseca ao jogo de futebol não era tolerada pelos jornalistas esportivos. Para Mazzoni e Mário Filho, o bom jogador deveria atuar civilizadamente, com lealdade dentro de campo, respeitando as regras do esporte e propagando beneficamente o nome do Brasil em terras estrangeiras quando os confrontos eram internacionais.

Ao serem analisadas as notícias presentes nos jornais esportivos, é possível notar uma condição a ser respeitada pelas classes populares para conseguir uma melhor colocação social: agir de acordo com os padrões civilizados de sociabilidade, ou seja, com disciplina, altruísmo e educação. Assim, o caldeamento étnico não acontecia fisicamente, mas ideologicamente pela vinculação da imagem dos esportistas populares aos valores burgueses.

Na entrevista na Gazeta Esportiva, o técnico da Portuguesa de Esportes, Conrado Ross, falou sobre alguns desses princípios elitistas presentes no futebol:

\begin{abstract}
"Disciplina, como eu a entendo, não quer dizer sujeição absoluta. Disciplinado é todo o jogador que obedece ao técnico e ao seu comandante, o capitão do quadro. Disciplinado é todo o jogador que cabe ver a oportunidade de conquista de um ponto e compreende que há momentos em que mais facilmente assegurará a vitória de seu quadro cedendo ao companheiro a bola para o ponto que julga certo. Ele poderia atuar, sem ter, no entanto, a mesma chance que vê para o seu companheiro. Assim, disciplinadamente, desiste da glória de ser o marcador para assegurar a marcação, pelo outro!" 294 .
\end{abstract}

A valorização do comandante dentro e fora de campo, a necessidade de jogar com disciplina e atuar pensando no coletivo em detrimento do individualismo próprio do futebol profissional era comum nos periódicos esportivos. Além de exaltar os valores elitistas presentes no futebol desde a época amadora, estava em jogo a divulagação da ideologia do Estado Novo.

\footnotetext{
${ }^{294}$ Gazeta Esportiva, 22 de março de 1941, p. 5.
} 
Desse modo, no discurso articulado pelos jornalistas esportivos, o individualismo, a violência e a indisciplina deveriam inexistir no modo brasileiro de praticar o futebol, pois esses elementos representavam arcaísmo e barbárie.

Durante o jogo Vasco versus Corinthians disputado em São Januário, em 7 de abril de 1940, ocorreram inúmeros atos de violência e indisciplina, conforme destacou o Jornal dos Sports:

\begin{abstract}
"Os quadros se apresentaram muito abaixo do que se esperava technicamente e aggravaram a pobreza do espetáculo com um emprego de brutalidade que chegou a forçar o delegado chefe do policiamento a interromper o jogo para chamar à ordem o juiz e os jogadores” ${ }^{295}$.
\end{abstract}

Os árbitros de futebol cuja função de ser a autoridade dentro de campo conferiu a esses profissionais a alcunha de “juízes”, eram constantemente criticados nas matérias sobre os jogos por não preservarem a harmonia dentro de campo. Vale ressaltar o envolvimento do principal árbitro carioca no período, Mário Viana, com a Polícia Especial do Estado Novo, como indício do embricamento existente entre futebol e política.

A matéria publicada em dezembro de 1939, no Jornal dos Sports, trouxe a seguinte crítica sobre a atuação do árbitro paulista na segunda partida final do Campeonato Brasileiro desse mesmo ano:

\footnotetext{
"Não há nenhuma discordância a respeito da actuação do árbitro paulista que controlou a peleja no Parque Antártica. Todos são unânimes em affirmar que a arbitragem não só foi sivada [sic] de erros como também prejudicou visivelmente os cariocas. A escolha de um juiz para o Campeonato Brasileiro devia obedecer a um critério fixo. Não se comprehende que ainda tal assumpto dependa de conveniencia eventual das entidades (...) O Campeonato Brasileiro necessita ser leal, puramente technico para estabelecer intercambio dos centros maiores com os centros menores, provocando uma verdadeira transfusão de qualidades adquiridas, o Campeonato Brasileiro perde toda a finalidade, transformando-se em uma competição estreita
}

295 Jornal dos Sports, 9 de abril de 1940. 
de regionalismos bem contrários à noção pura do sport” ${ }^{296}$.

Nesse texto, Mário Filho realizou uma crítica que ultrapassou a atuação do árbitro na partida, analisando o próprio sistema de escolha dos árbitros. Utilizando da ironia, ao comparar São Paulo como um centro de menor importância no futebol brasileiro, o jornalista carioca considerou os erros decorrentes das falhas técnicas ou da má escolha da arbitragem como um perigo à própria unidade nacional.

Pode-se considerar essa reportagem como um intertexto às avessas, pois o jornalista alertou sobre o poder da paixão futebolística em provocar sentimentos regionalistas e, concomitantemente, agiu imbuído desses sentimentos quando discutiu o problema da arbitragem depreciando o futebol paulista.

Além disso, a matéria colocou a preocupação de manter o futebol alinhado aos interesses do governo em fazê-lo o esporte nacional capaz de unir territorialmente e ideologicamente a nação via um campeonato nacioanal. Para Mário Filho, o futebol deveria enaltecer a pátria e não promover separatismos e, para isso, caberia às diferentes ligas futebolísticas inscritas no torneio atuar com técnica, disciplina e harmonia.

Nesse sentido, para Mazzoni, o processo de profissionalização do futebol não era responsável pela crise presente nesse esporte durante a passagem do amadorismo para o profissionalismo. O verdadeiro algoz desse esporte seria a "mentalidade clubística” entendida como os interesses individuais defendidos pelas pessoas que dirigiam o futebol nacional ${ }^{297}$.

De acordo com Plínio Negreiros, o jornalista paulista defendia a intervenção do

\footnotetext{
296 Jornal dos Sports,19 de dezembro de 1939, p. 2.

${ }^{297}$ NEGREIROS, Plínio José Labriola de Campos. Op. cit., p. 59.
} 
governo estadonovista para ordenar o futebol nacional, pois um esporte bem estruturado

auxiliaria a missão do Estado e da crônica esportiva como porta-voz dos interesses

estadonovistas, a promover a disciplinarização da massa torcedora:

\begin{abstract}
"Além de defender medidas paliativas que pudessem melhorar o futebol em certas circunstâncias, tinha um proposta muito clara e que não deixou de defender: o futebol no Brasil deveria ser organizado pelo Estado e não mais pelos dirigentes dos clubes. Estes, para Mazzoni, de tão viciados, não tinham como ser recuperados para uma nova ordem esportiva. O sucesso do golpe de 10 de novembro de 1937, que deu origem ao Estado Novo, levou o cronista da Gazeta a acreditar que os ares do novo regime logo chegariam aos esportes. Ou seja, Mazzoni entendia que a intervenção do governo nas questões esportivas viria com rapidez, já que seria plenamente compatível com a ordem que estava se estabelecendo no país (...) na sua jornada em defesa de uma nova ordem para os esportes, inclusive utilizando-se de um quase bordão: Quando o $1^{\circ}$ de novembro chegar ao futebol esse tipo de abuso não mais irá ocorrer" ${ }^{298}$.
\end{abstract}

Nessa defesa ideológica ao regime estadonovista, Mazzoni apontava o individualismo como o elemento mais nocivo à concretização do futebol brasileiro prevalecendo, inclusive, sobre o clubismo e o bairrismo:

"Considerados por Mazzoni como uma das três chagas que depunham contra o futebol brasileiro, comparados somente à indisciplina dentro de campo, que dizia respeito as constantes aclimatações às regras, e às lutas políticas entre ligas esportivas, federações e confederações de sua época, o clubismo e o bairrismo foram definidos, naquilo que interessa salientar no momento, como desdobramentos da má conduta de parte dos especialistas, coresponsáveis pelas mazelas por ele disseminadas. Espécie de exacerbação da paixão associada à posição privelegiada que estes ocupavam no trânsito das demandas e interesses de dirigentes de clubes, ligas ou federações estaduais” ${ }^{299}$.

A indisciplina igualmente estava entre os elementos repudiados por Mazzoni, em consonância ao projeto estadonovista de nação. Para o jornalista paulista, a imprensa como propagadora dos valores governamentais deveria dar o exemplo e se comportar harmonicamente:

\footnotetext{
${ }^{298}$ Idem. Ibidem. p. 60.

${ }^{299}$ TOLEDO, Luíz Henrique de. Op. cit., p. 184.
} 
“A imprensa, no mais das vezes, é quem forma o ambiente, especialmente para os confrontos de maior tensão, de circunstâncias excepicionais. Se essa imprensa foge de sua verdadeira missão, se é escandalosa e perniciosa, envenena o ambiente” ${ }^{300}$.

O trecho acima demonsta que a parcialidade da imprensa era reconhecida pelo jornalista, mas essa deveria ser utilizada para alavancar os ideais de regime. Nesse sentido, José Carlos Marques destacou a prática de “inventar notícias” como algo comum na busca de arrebanhar um maior número de leitores durante os anos 30, do século XX. De acordo com o autor, as entrevistas com jogadores de futebol eram degeneradas a tal ponto que alguns dirigentes de futebol, em São Paulo, proibiram os jogadores de falar com jornalistas ${ }^{301}$.

Outra atuação fundamental na defesa da profissionalização do futebol foi aquela apresentada pelo jornalista Mário Filho. Para o jornalista carioca, caberia ao futebol profissional divulgar os projetos nacionais formulados pelo governo a um maior público, além de legitimar o cargo de jornalista esportivo:

\begin{abstract}
“A atuação de Mário Filho nos bastidores do futebol foi de certo modo decisivo para que o profissionalismo vingasse no futebol brasileiro no início dos anos 30. Assumindo o caráter de ocupação remunerada, esse esporte passava a encarar de outra maneira a relação entre jogadores, clubes e platéia. Da mesma forma, a imprensa poderia dispor mais elementos para também se defrontar com uma nova ocupação profissional, qual seja a do jornalista esportivo" 302
\end{abstract}

Em sua tese de doutorado, Fátima Antunes analisou a campanha realizada por Mário Filho desde o início da profissionalização do futebol, quando ocorreu a cisão no

\footnotetext{
${ }^{300}$ MAZZONI, Tomás. Problemas e aspectos do nosso futebol. São Paulo: A Gazeta, 1939. p. 31 apud MARQUES, José Carlos. Op. cit., p. 79.

${ }^{301}$ Idem. Ibidem. p. 80.

${ }^{302}$ Idem. Ibidem. p. 81.
} 
futebol carioca:

“Acreditava que os jogadores deveriam ser pagos para jogar. Além disso, sabia que o jornalismo esportivo seria beneficiado com o desenvolvimento do futebol profissional e com o aumento do público interessado. De certa forma, a própria imprensa já vinha contribuindo para a formação de um público de massas para o futebol, na medida em que dava mais destaque ao assunto (...) Para incentivar o público a comparecer aos jogos do campeonato organizado pela Liga Carioca, Mário Filho convenceu os dirigentes de clubes a promoverem campeonatos entre as torcidas pelo jornal $O$ Globo. Receberiam prêmios os grupos mais animados e criativos, o primeiro torcedor que chegasse ao estádio, e assim por diante. As arquibancadas ganharam as cores dos clubes, vestindo-se de bandeiras, animadas pelos fogos de São Jorge e pelas bandas carnavalescas" 303 .

Essa atuação de Mário Filho na promoção do futebol profissional estava em concordância com os ideais estadonovistas em utilizar o futebol para incutir à massa torcedora os valores do regime. Nesse sentido, torna-se compreensível o contato do jornalista com políticos importantes sendo, inclusive, amigo pessoal do presidente Getúlio Vargas:

“O respeito conquistado não apenas no meio esportivo, mas também entre políticos e intelectuais, permitiu-lhe exercer uma ação política real na conformação e no desenvolvimento, sobretudo, do profissionalismo no futebol. Conquistou a confiança de Getúlio Vargas e teve acesso facilitado ao seu gabinete, tanto no período do Estado Novo como, posteriormente, durante o mandato ganho nas urnas” 304 .

Os jornalistas sempre associavam um bom jogo àquele disputado cordialmente e sem violência entre os combatentes, ainda que fosse um jogo sem muitos gols ou belas jogadas. Nessa matéria há um importante elemento analítico, a saber: a presença policial no futebol.

A despeito das normas e regulamentações engendradas pelo Estado para burocratizar e controlar o futebol, a própria força policial como instrumento de coerção

\footnotetext{
${ }^{303}$ ANTUNES, Fátima Martin Rodrigues Ferreira. Op. cit., p. 106.

${ }^{304}$ Idem. Ibidem. p. 108.
} 
do aparelho estatal, ficava sempre à beira do gramado para entrar em ação em situações extremas.

Em uma sociedade calcada no autoritarismo na qual a ordem, a disciplina e a harmonia social deveriam ser preservadas sempre, não importando os meios necessários para as suas realizações, a presença policial nos campos de futebol era considerada normal e imprescendível pelos espectadores e jornalistas.

Além da violência e indisciplina praticada dentro de campo pelos profissionais da bola, a rebeldia dos torcedores eram igualmente combatidas pelo regime e, por consequência, severamente criticada pela imprensa. Sobre a falta de cordialidade da torcida carioca, a Gazeta Esportiva publicou a seguinte notícia:

\begin{abstract}
"Pela primeira vez tivemos um prélio menos compatível com a cordialidade que vem predominando ao torneio, graças à indisciplina da 'torcida' carioca que não corresponde ao tratamento que São Paulo tem dispensado aos clubes da Guanabara. Quando o árbitro Mario Viana espulsou [sic] Juarez, do São Paulo, na partida com o Flamengo, houve manifestações de desagrado, mas nem o tricolor paulista degenerou para a violência, nem o publico hostilizou o Flamengo com vaias, pedras, garrafas cascas de laranja, como aconteceu quarta-feira última, ao ser Leônidas expulso por atingir Junqueira com um pontapé. O público de lá, que não admite punição, quer dirigindo-os com objetos de várias espécies, quer recebendo-os sob tremenda assuada quando regressaram para o segundo tempo. E mais se lamentam tais fatos e atitudes em face do espírito de hostilidade e simpatia que tem sido acolhidos os 'esquadrões' cariocas, sempre admirados e aplaudidos, sejam tecnicamente, bem ou mal sucedidos” ${ }^{305}$.
\end{abstract}

A despeito da rivalidade regional presente na reportagem, as críticas escritas contra a torcida rebelde confirmam a importância conferida ao ordenamento social. Uma massa indisciplinada poderia representar um perigo latente, um potencial inimigo para um Estado constituido ilegitimamente.

Assim, era fundamental educar essa massa nos moldes ideológicos do Estado Novo. Nessa missão civilizadora, a imprensa esportiva desempenhou um importante papel ao criticar as práticas contrárias a essa ideologia quando eram praticadas pelos futebolistas e por seus torcedores.

${ }^{305}$ Gazeta Esportiva, 24 de agosto de 1940, p.7. 
Porém, ao se comportarem como verdadeiros torcedores de seus estados e expressarem esse sentimento regionalista pela paixão futebolística, Mazzoni e Mário Filho trocaram ofensas entre si inúmeras vezes, contrariando os princípios cavalheirescos por eles defendidos. Ao analisar os conflitos presentes entre esses dois cronistas, percebe-se a concepção bairrista do estado de São Paulo em tensão com clubismo carioca $^{306}$.

Em abril de 1945, Mario Filho lamentou a renda do último Palmeiras versus Flamengo, em São Paulo, de setenta e cinco mil cruzeiros. Além disso, o editor do Jornal dos Sports aconselhou os times cariocas a não jogarem mais em São Paulo para darem mais atenção ao campeonato local, onde "boas rendas haveriam de ser arrecadadas porque o público guanabarino estava interessado, muito interessado, nos cariocas”. Assim, a Gazeta Esportiva respondeu a colocação carioca:

\footnotetext{
"Mas, veio o Torneio Relâmpago. Choque entre os seis maiores clubes da cariocolandia não vão além de 50 mil cruzeiros. Chega-se a realizar dois jogos em cada noitada, e a renda não ultrapassa tal quantia. Ah, 'seu' Mario Filho, como deve ter sido bem maior essa sua nova decepção... Um Palmeiras x Jabaquara produz 59 mil cruzeiros e América x Fluminense não vai além de 38 ” 307.
}

Apesar do alinhamento com os ideais do Estado Novo, o despeito e a provocação presentes na matéria demonstram a rivalidade dos dois maiores jornais esportivos do país, a disputa para concretizar o futebol de seus estados como o mais forte do Brasil e o próprio conflito existente entre as elites regionais para se colocarem no plano decisório dos rumos políticos da nação.

A historiadora Fátima Antunes ressalvou, em sua tese de doutorado, como esse

\footnotetext{
${ }^{306}$ ANTUNES, Fátima Martin Rodrigues Ferreira. Op. cit., p. 144.

${ }^{307}$ Gazeta Esportiva, 7 de abril de 1945, p. 5.
} 
conflito se apresentava na crônica de Mário Filho, pois o jornalista defendia a unidade nacional destacando a rivalidade regional entre São Paulo e Rio de Janeiro:

\begin{abstract}
“Contudo, Mário Filho assegurava que, na militância por provar a sua superioridade, os paulistas se uniam em apoio a qualquer um dos clubes que se confrontasse com um carioca. $\mathrm{O}$ cronista via nessa atitude uma demonstração do bairrismo paulista. Contrastando esse sentimento, estaria a tendência brasileira do futebol carioca, mais cosmopolita e representante mais maduro de um futebol nacional” 308.
\end{abstract}

Ambos os jornalistas defendiam os clubes e as entidades de seus respectivos estados e torciam pela convivência harmônica desses interesses. Porém, na prática, estabelecia-se uma rivalidade regional fora dos gramados e a Gazeta Esportiva sempre reclamava mais dos atos praticados pelos elementos cariocas.

Levantou-se a hipótese de isso ocorrer devido a localização do Jornal dos Sports ser na capital da República, onde as instituições reguladoras do futebol e da política em geral estavam instaladas. Além disso, deve-se considerar o fato de ser o futebol carioca o melhor estruturado, com mais títulos nacionais e jogadores escalados na composição do selecionado nacional até meandros da década de 40, século XX.

Outra questão que merece ser analisada para tentar compreender os recorrentes reclames da imprensa paulista seria o conflito existente entre a elite de São Paulo, dona dos principais jornais do estado, e o regime estadonovista sediado no Rio de Janeiro e representado pela elite carioca. Assim, os esforços praticados pelo estado de São Paulo em voltar ao plano decisório do país assim como o era antes de Vargas decretar o governo provisório configaram uma outra hipótese para analisar essa quetão.

Se a política estadonovista utilizou-se do futebol para divulgar e concretizar

\footnotetext{
${ }^{308}$ ANTUNES, Fátima Martin Rodrigues Ferreira. Op. cit., p. 144.
} 
seus ideais, a elite paulista com as crônicas esportivas, concomitantemente, vinculou o futebol ao seus projeto de novamente reger a nação.

Desse modo, o dia-a-dia dos cronistas reforçava os valores nacionais projetados pelo Estado Novo na massa torcedora, ao mesmo tempo em que suas paixões clubísticas e regionalistas afloravam a tensão presente nesse conflituoso jogo de poder. 


\section{NAS ARQUIBANCADAS}

\subsection{A Assistência da Nação}

No discurso pronunciado por Vargas na ocasião do terceiro aniversário de instauração do Estado Novo, ao falar sobre as rivalidades, desunião e conflitos sociais presentes na República Velha e findados com o novo regime, o presidente utilizou uma expressão muito comum em nosso cotidiano, a saber "entrar em campo":

"De volta com os remanescentes do faccionismo partidário, o caudilhismo e o regionalismo, entraram em campo os exotismos extremistas procurando sobrepor-se aos superiores interesses da Nação. Veio o 10 do novembro, movimento orgânico completo e integral que, dando estructura política às reivindicações de 1930, restaurou o Brasil nas suas tradições históricas e glorias de seu passado integrando-o nas realizações de seu presente e nas aspirações de seu futuro. A revolução continuava e entrava afinal no período construtor” ${ }^{309}$.

A figura de linguagem utilizada elucida o enraizamento do futebol na sociedade como fato social total ${ }^{310}$, fruto do ritual público cotidianamente vivido pelos brasileiros, torcedores ou não de futebol. Além disso, sua utilização nos remonta à utilização do futebol por parte do governo estadonovista para a concretização dos seus projetos políticos.

Como demonstrado anteriormente, por diversas vezes foram encontrados nos periódicos analisados propagandas e concursos esportivos associando o futebol aos ideais estadonovistas de unidade nacional, disciplina, ordem, eugenismo, harmonia social e outros fatores político-econômicos próprios de situações presentes no momento

\footnotetext{
${ }^{309} \mathrm{O}$ trecho destacado foi retirado do discurso publicado no Correio Paulistano, em 10 de novembro de 1940, p.2. Grifo nosso.

${ }^{310}$ MAUSS, Marcel. Op. cit., p. 24.
} 
de suas divulgações.

Um dos acontecimentos sociais amplamente utilizado pelo goveno para vingar seus planos políticos, firmar-se internamente e realizar uma propaganda positiva do Brasil no exterior, foi a Copa do Mundo de Futebol disputada na França, em $1938^{311}$. Sobre a mobilização causada pelo evento, o Correio Paulistano trouxe a seguinte matéria:

\begin{abstract}
"Excepcionalmente, como talvez nunca tenha acontecido, o interesse aqui na capital da República, foi geral. O Departamento Nacional de Propaganda collocou vários alto-falantes em diversos pontos da cidade (...) Os jornais da tarde, publicaram, com todo destaque, photographias tiradas no Palácio da Guanabara, do presidente Getúlio Vargas, senhora e filha, assistindo pelo rádio ao desenrolar da peleja. Nota-se uma expressão absoluta de interesse na physionomia do Chefe de Estado e de sua exma. família (...) A imprensa, por outro lado, informa que Leonidas, o 'crack' que abriu o escore, vae receber mais de 10:000\$000 em prêmios. Adeanta-se, ainda, que o sr, Luis Aranha, presidente da CBD, em nome do governo, offerecerá uma casa aos ‘cracks', caso o Brasil saia vencedor no campeonato do Mundo”, ${ }^{312}$.
\end{abstract}

Ao analisar a notícia percebe-se o imbricamento existente entre política e futebol e como a primeira se utilizava do jogo com bola para cativar a massa e propagar seus ideais. O próprio fato de a Confederação Brasileira de Desportos, órgão estatal para regulamentar os esportes no país, ter prometido um prêmio a cada jogador caso a seleção fosse a campeã do torneio, demonstrava a importância do futebol para propagar internamente os ideais do Estado Novo e, externamente, divulgar uma boa imagem do Brasil.

Os prêmios prometidos aos futebolistas, divulgados no final da reportagem, além de acentuarem o profissionalismo desse esporte, procuravam criar um vínculo entre artistas da bola e governo autoritário, comprometendo os atletas a jogarem em prol

\footnotetext{
${ }^{311}$ A Gazeta de Notícias trouxe na capa de suas edições notícias sobre a campanha da seleção brasileira no Mundial de Futebol disputado em Paris nas seguintes datas: 01/05/1938, 07/06/1938, 09/06/1938, 10/06/1938, 11/06/1938, 14/06/1938, 15/06/1938, 17/06/1938, 19/06/1938, 23/06/1938 e 12/07/1938.

${ }^{312}$ Correio Paulistano, 7 de junho de 1938, p.9.
} 
dos valores estadonovistas.

Além disso, a ascenção social dos jogadores provenientes das classes sociais menos abastadas economicamente, como Leônidas da Silva, ficou evidente quando o jornalista nos informou o valor que o futebolista ganhou por fazer apenas um dos gols brasileiros no Mundial de Futebol.

Ainda analisando a notícia, nota-se que a mobilização provocada pela seleção brasileira de futebol foi descrita como um fenômeno novo na sociedade. O fato pode ser explicado pela constituição recente do profissionalismo no futebol brasileiro e pela embrionária iniciativa do Estado em valorizar a prática e a publicidade desse esporte com o intuito de reforçar a sua ideologia na sociedade.

Durante a preparação do selecionado brasileiro foi organizada a campanha do selo com o objetivo de arrecadar fundos para enviar a seleção brasileira de futebol para a disputa do título Mundial. Cada selo custava 500 réis e trazia impresso a seguinte frase: "auxiliar a scratch é dever de todo o brasileiro”. Além dessa verba, o Banco do Brasil doou 20:000\$000 e o Moinho Inglês 5:000\$000 para custear as despesas da delegação nacional de futebol ${ }^{313}$.

O apelo patriótico para motivar a população e as empresas a patrocinarem o selecionado nacional estava centrado na ideia de demonstrar a melhor imagem do Brasil no exterior. Sobre essa propaganda nacional realizada pelo futebol, Negreiros escreveu:

“Assim, o campeonato de futebol colocava em jogo os próprios destinos da nação, ao menos por duas razões. De um lado, a imagem do Brasil seria representada a vários povos europeus, que poderiam ter contato com o atual estágio de desenvolvimento do país, ou, conforme expressão da época, poderiam conhecer os níveis de progresso atingidos pelo Brasil. De outro lado, estaria em jogo a capacidade de organização e de envolvimento da população brasileira

\footnotetext{
${ }^{313}$ FRANZINI, Fábio. Op. cit., p. 70.
} 
dentro desse processo" ${ }^{314}$.

Nesse sentido, para uma maior aproximação entre o governo e o povo via futebol o DIP colocou alto-falantes em diversos locais no Rio de Janeiro para a massa torcedora acompanhar os jogos e nomeou a filha do presidente, Alzira Vargas, como madrinha do selecionado brasileiro.

${ }^{314}$ NEGREIROS, Plínio José Labriola de Campos. Op. cit., p. 260. 


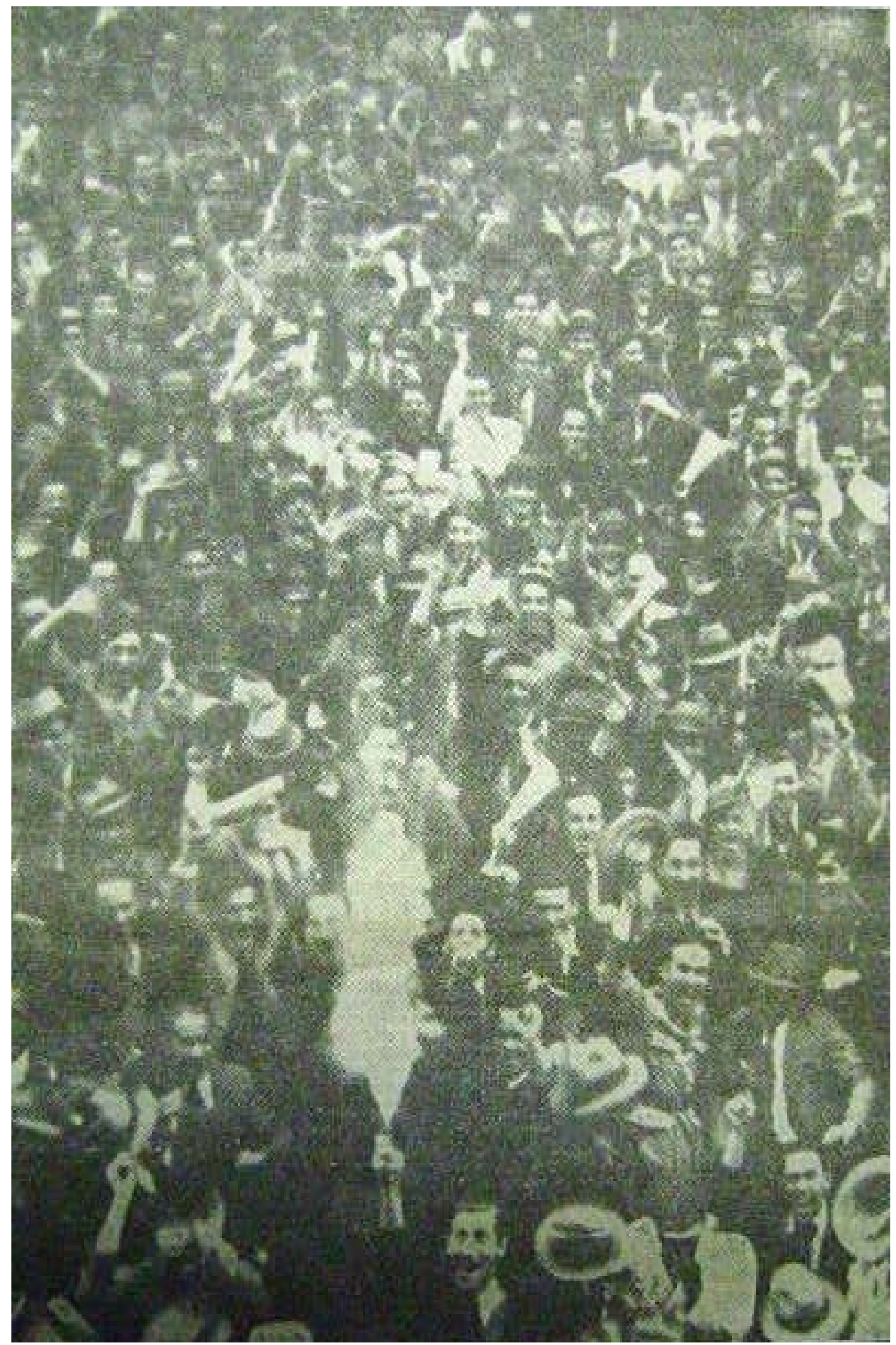

Torcida em frente ao prédio da Gazeta, ouvindo a irradiação do jogo Brasil versus Polônia, válido pelo Mundial de Futebol, em 1938. Gazeta Esportiva, 06 de junho de 1938, p. 3. 


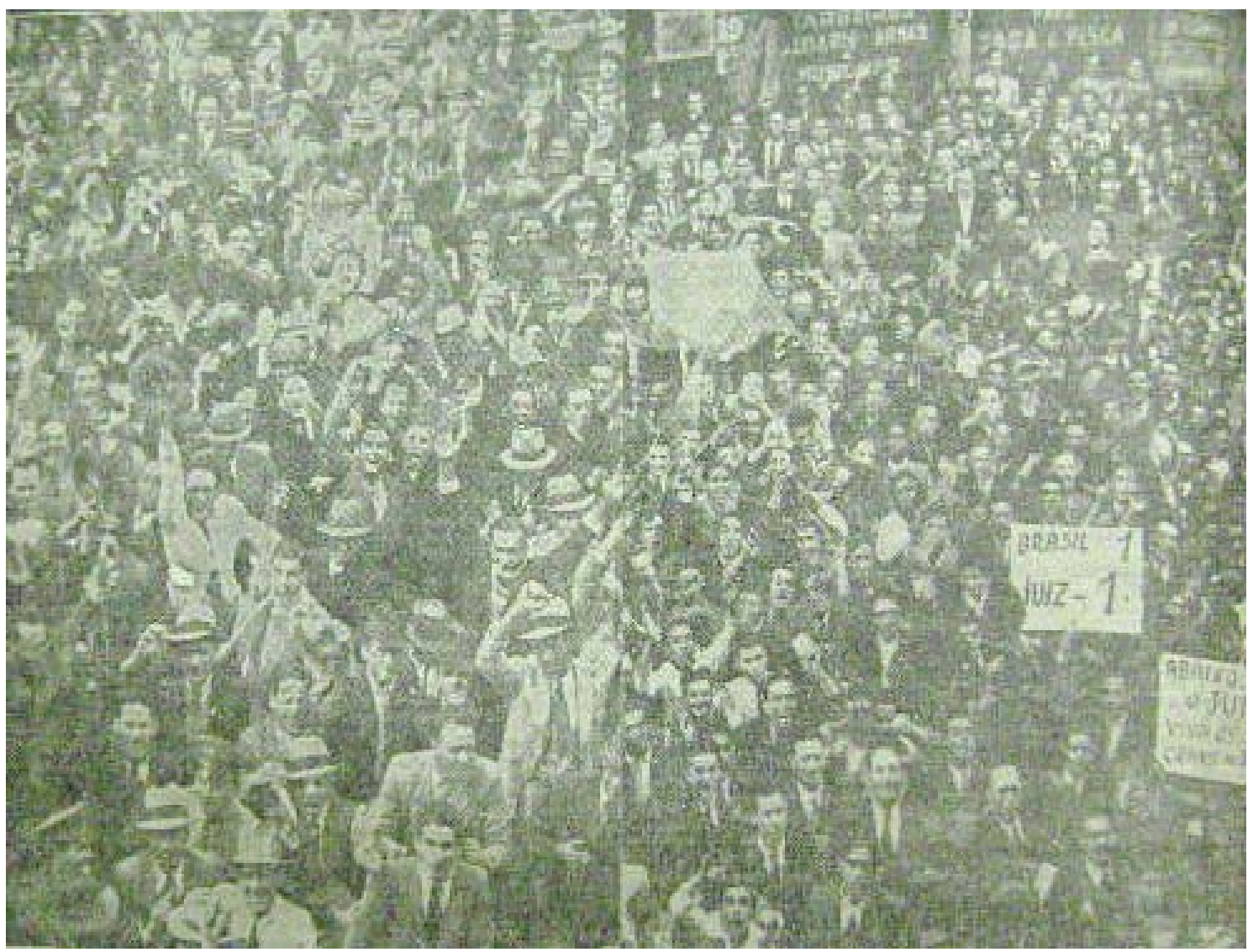

Multidão durante as irradiações dos jogos da seleção brasileira disputados pelo Campeonato Mundial de 1938. Gazeta Esportiva, 13 de junho de 1938, p. 12.

Além disso, o interesse explícito do presidente Vargas e família nas irradiações dos jogos, auxiliava na caracterização do Estado Novo como um regime popular próximo do gosto e das necessidades do povo.

A Copa do Mundo de Futebol em 1938, nas palavras de Negreiros, reforçou o ideal estadonovista de construção nacional:

"Simbolicamente, reforçou-se a idéia de que não era uma mera disputa esportiva, mas uma provocação com o intuito de mostrar a força do Brasil, do seu povo, a partir do futebol. De diversas maneiras, cada brasileiro foi responsabilizado pelo desempenho dos atletas de futebol” 315

${ }^{315}$ NEGREIROS, Plínio José Labriola de Campos. Op. cit., p. 302. 


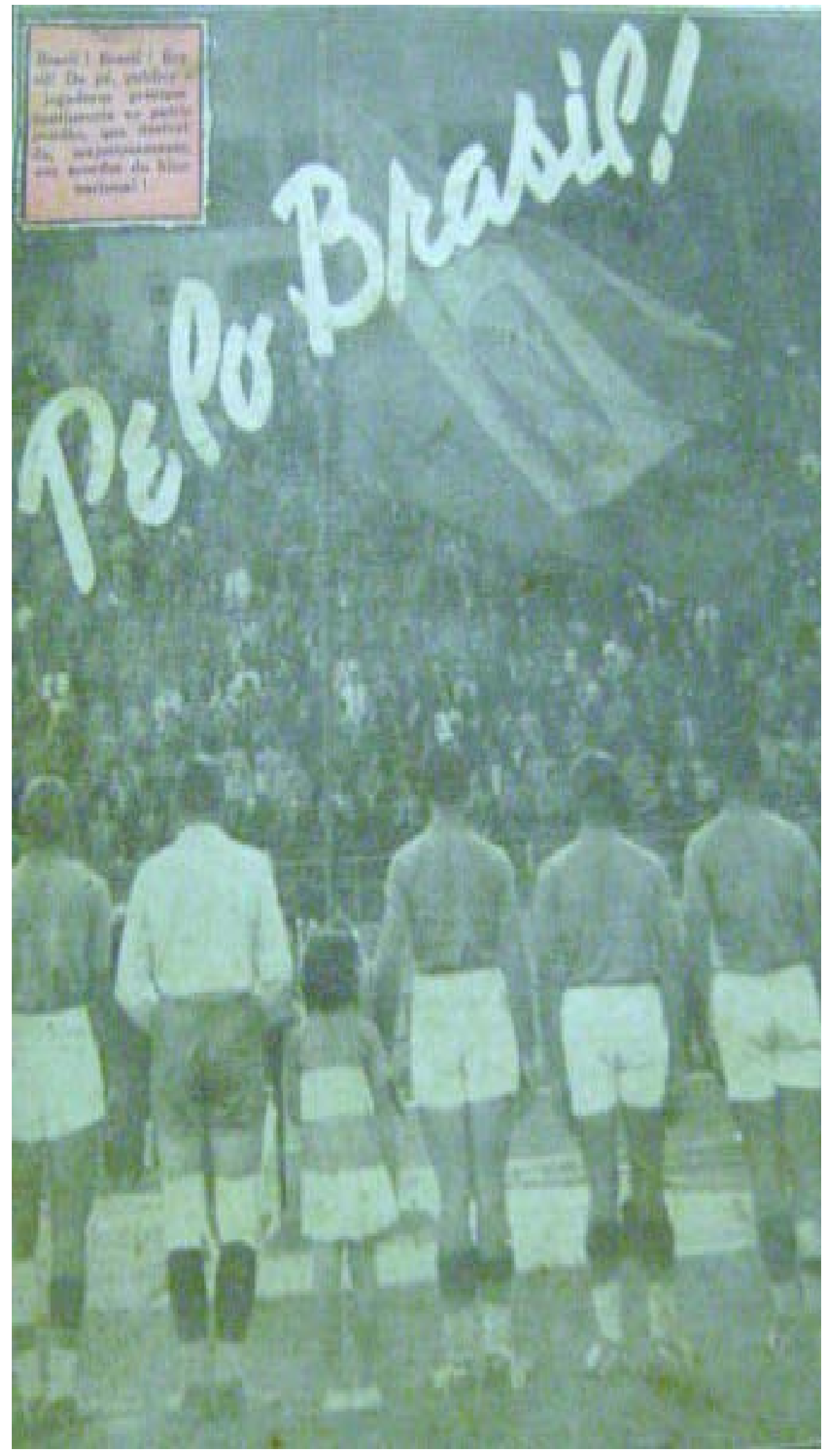

Jogadores em frente à bandeira nacional no jogo Goiás versus Mato Grosso, pelo Campeonato Brasileiro. Os estados da confederação, representados por seus selecionados, curvam-se respeitosamente à União, representada pelo símbolo pátrio. Gazeta Esportiva, 10 de novembro, 1941, p. 1. 


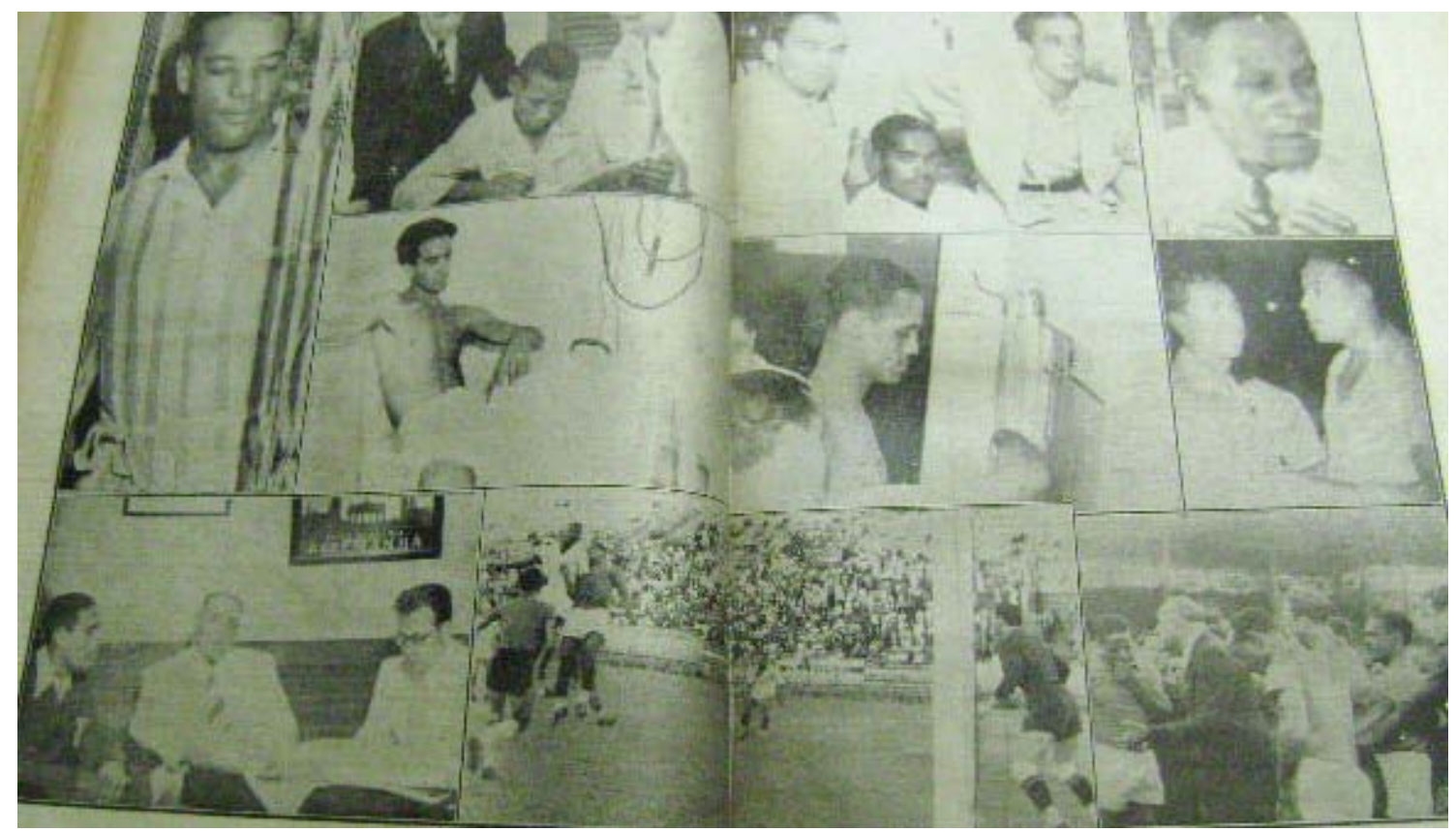

As diversas fases da cuidadosa preparação dos jogadores da seleção brasileira para segundo jogo da Copa Roca, em 1939. O futebol profissional era devidamente regularizado e planejado para garantir um maior rendimento aos atletas e, assim, conseguir mais vitórias e propagar a imagem do país de forma digna e grandiosa. Gazeta Esportiva, 23 de janeiro de 1939, pp. 8-9.

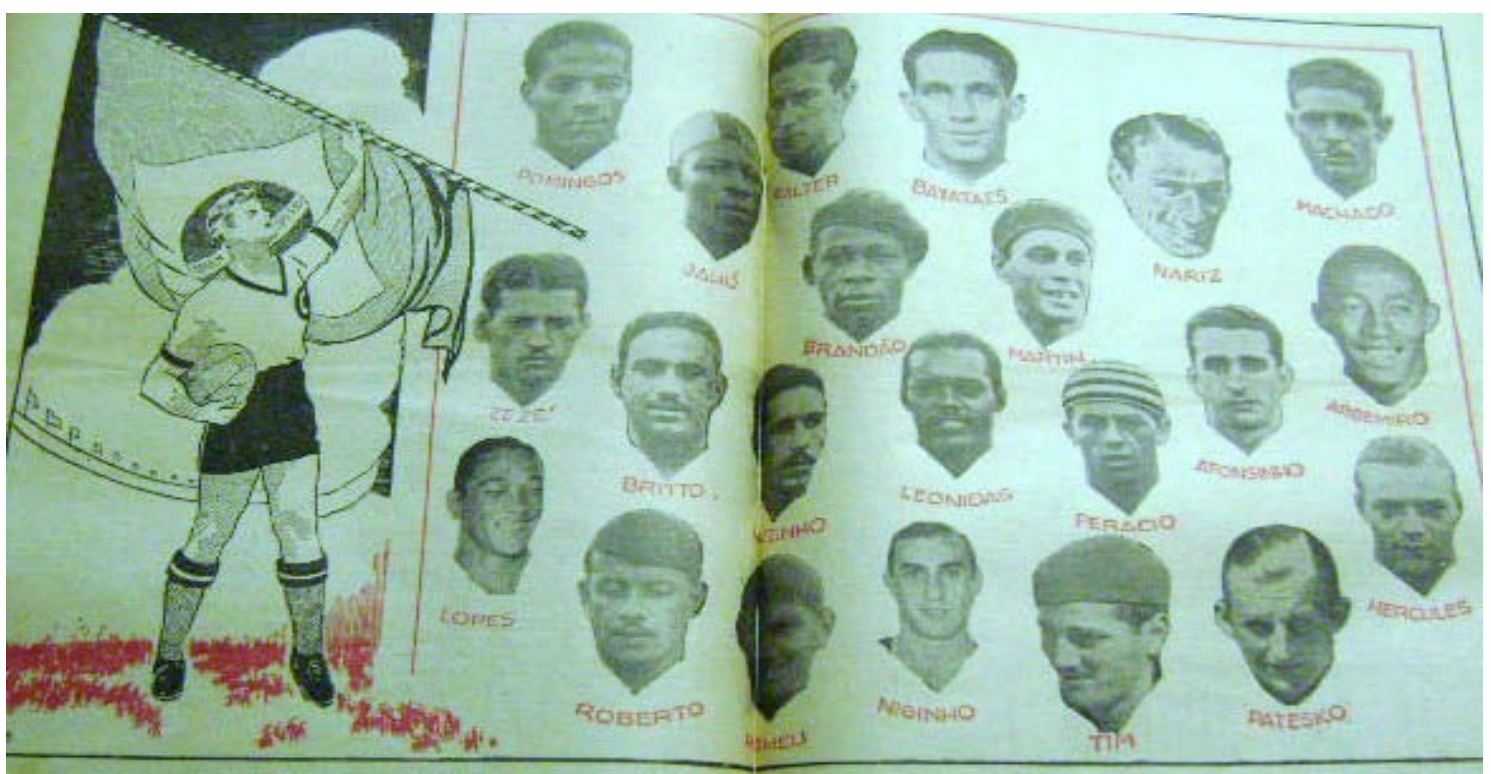

Jogadores da seleção brasileira como os “embaixadores do Brasil” no exterior durante a Copa do Mundo de Futebol, em 1938. Caberia a esses vinte e um homens elevar a imagem do país em terras estrangeiras, assim como o jogador desenhado faz de cabeça erguida com a bandeira nacional. Gazeta Esportiva, 06 de junho de 1938, pp. 8-9. 
Outra forma de propaganda política baseada no interesse futebolístico da massa

publicada nos períodicos eram aquelas realizadas com os próprios jogadores de futebol.

Como exemplo, destaca-se a imagem dos jogadores botafoguenses Carvalho Leite, Sardinha e Borges que, por ocasião do jogo Botafogo versus American All Stars, de Nova Iorque, foram fotografados tomando uma imensa xícara de café. Fazia parte da política de boa vizinhança oferecer aos jogadores latinos visitantes a bebida mais consumida por ambos os países.

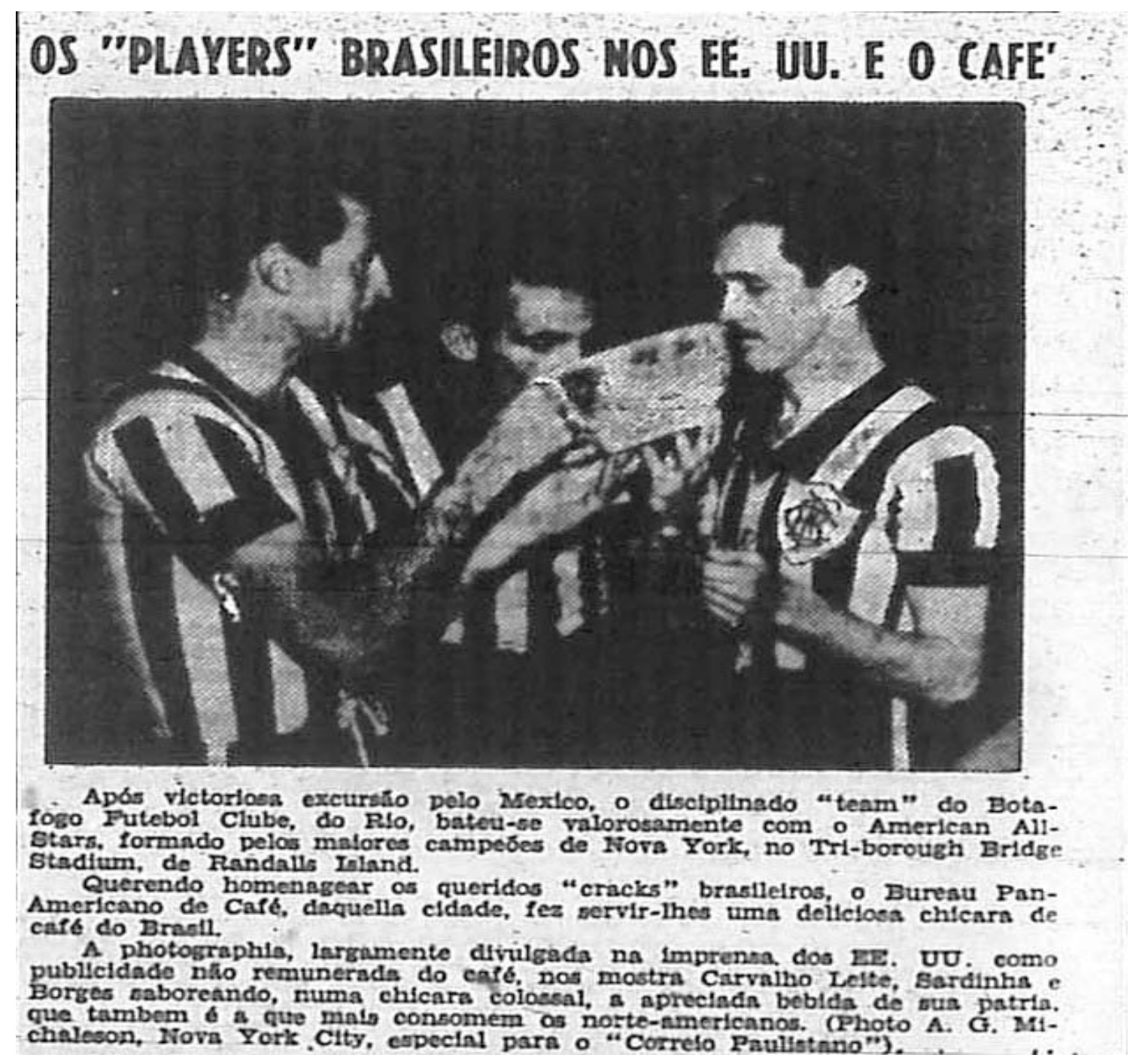

Jogadores do Botafogo fazendo propaganda gratuita do principal produto de exportação do Brasil no exterior, o café. Percebe-se que a notícia destacou como principal característica do vitorioso time do Botafogo a sua disciplina dentro e fora dos gramados. Correio Paulistano, 13 de abril de 1941, p. 16. 
Jogos beneficentes de futebol auxiliavam na concretização de missões com caráter político e, concomitantemente, realizavam uma propaganda positiva do governo deixando-o como uma entidade capaz de resolver as situações críticas.

Nesse sentido, duas partidas contrapondo as seleções carioca e paulista foram realizadas, em 1941, para auxiliar financeiramente os moradores do Rio Grande do Sul após a grande enchente ocorrida naquele estado ${ }^{316}$.

O primeiro jogo foi realizado no estádio das Laranjeiras no Rio de Janeiro, em 28 de maio de 1941. O resultado final da movimentada partida assistida por um público numeroso foi de 6 x 5 para os cariocas ${ }^{317}$. No segundo jogo, disputado em 04 de junho de 1941 no estádio do Pacaembu, em São Paulo, a vitória foi dos paulistas, por três gols a zero $^{318}$.

Porém, o periódico voltou a escrever sobre a segunda partida criticando a ética dos clubes que, de acordo com o jornalista, somente pensavam em lucrar com o futebol - elemento que deveria sintetizar os valores do Estado Novo de unidade coletiva e solidariedade entre as diferentes classes sociais em prol da nação brasileira:

\begin{abstract}
"O resultado do último encontro entre os selecionados paulistas e cariocas não surpreendeu ninguém (...) deixou no entanto contristados todos que julgam e pensam ser os esportes no momento atual um dever patriótico. Assim, porém, não pensam os dirigentes de nossos clubes que criam toda serie de dificuldades desde que a renda não reverta para benefício próprio. $\mathrm{E}$ foi esse o motivo de se mandar para São Paulo um selecionado formado quase que exclusivamente por reservas..." 319
\end{abstract}

Analisando os dados sobre essas partidas, vislumbra-se a intensa presença do

\footnotetext{
316 Outro exemplo de partida beneficente ocorreu em agosto de 1943, entre os selecionados paulista e carioca de futebol para arrecadar fundos para a "Campanha do Cigarro Prol Soldado Brasileiro", ou seja, para auxilar na manutenção dos combatentes brasileiros em ação na Europa.

${ }^{317}$ Gazeta de Notícias, 29 de maio de 1941.

${ }^{318}$ Gazeta de Notícias, 05 de junho de 1941.

${ }^{319}$ Gazeta de Notícias, 07 de junho de 1941, p. 10.
} 
público nesses eventos filantrópicos motivados pelo fato de o jogo ser disputado entre os dois maiores selecionados do país. O futebol como um forte elemento catalisador de diferentes classes sociais serviu para legitimar o governo e propagar seus valores.

Porém, de acordo com o jornalista, as entidades controladoras do futebol não prestigiavam o evento da mesma forma, pois estavam mais interessadas nos lucros provenientes de seu profissionalismo.

Assim, percebe-se o futebol profissional como uma atividade voltada ao espetáculo para mobilizar a massa e angariar lucro para seus clubes. Além disso, a crítica do jornalista escrita contra o caráter mercantil do esporte reforça a sintonia dos valores estadonovistas com aqueles publicados pela imprensa, para as quais os estados deveriam se ajudar mutuamente como membros da mesma nação.

Sobre a função do Campeonato Brasileiro de futebol em promover a unidade nacional, Mario Filho escreveu:

\begin{abstract}
“Tecnicamente esse certame representa a melhor oportunidade para um intercambio real e eficiente entre as mais distantes regiões do país e o qual [sic] se tornaria praticamente impossível se ficasse dependendo apenas das iniciativas dos clubes ou das próprias entidades regionais. Financeiramente, também o certame nacional, representa a reserva única na qual se apoia a Confederação para movimentar os desportos amadores, cuja sorte, sem o apoio eficiente , não seria sem dúvidas das melhores (...) Deve existir um compromisso tácito de colaboração entre todos dos quais depende o sucesso do empreendimento e, essa colaboração será realmente efetiva quando se evitar, sinceramente, a criação de 'casos', quando se combater com decisão os excessos de regionalismos, tão prejudiciais em todos os sentidos e quando o torcedor, seja ele carioca, paulista ou fluminense, passar a olhar os quadros como irmãos em leal competição desportiva, e não como inimigos que se degladiam”" ${ }^{320}$.
\end{abstract}

Nessa reportagem, o editor do Jornal dos Sports resumiu a ideologia estadonovista em utilizar o futebol para promover a integração nacional. Para a realização dessa empreitada, os torcedores e instituições regularizadoras do futebol

\footnotetext{
${ }^{320}$ Jornal dos Sports, $1^{\circ}$ de dezembro de 1943, p. 2.
} 
deveriam se livrar dos sentimentos regionais, individualistas e parar de objetivar simplesmente o lucro.

Desse modo, a imprensa futebolística agia como a narrativa da ordem por meio da qual os ideais estadonovistas eram divulgados de maneira simples e natural para a massa torcedora. Esta, com a paixão futebolistica, se alinhava cada vez mais aos valores do regime.

Nesse contexto, a Gazeta Esportiva realizou um concurso para analisar qual era a melhor torcida uniformizada de São Paulo. Os principais elementos de análise dos jurados consistiam em itens básicos da idelogia estadonovista para a construção da nação: a educação, disciplina, harmonia, aperfeiçoamento, orientação, organização da massa e outros elementos empregados pelos componentes nas manifestações ordenadamente apresentadas.

Ao analisar os elementos que pontuavam no concurso para escolher a mellhor torcida uniformizada, Negreiros relacionou essas entidades com as práticas nazifascistas presentes no período:

“O futebol tinha de ser um espaço também educativo, em função de que a nação estava sendo construída e nenhum setor social poderia deixar de dar a sua contribuição. Educar, regenerar, aperfeiçoar, disciplinar: isso era esperado de todas as instituições brasileiras e ainda mais do futebol, por ser, talvez, mais brasileira que muitas outras, como já se começava a analisar” ${ }^{321}$.

Em afinidade com a ideologia nacional promovida pelo Estado Novo, o critério que conferia mais pontos à torcida uniformaizada era a disciplina (de 100 a 50 pontos), seguido pelo coro e organização (50 a 40 pontos). Em seguida vinham os demais

\footnotetext{
${ }^{321}$ NEGREIROS, Plínio José Labriola de Campos. Op. cit., p. 87.
} 
critérios - entusiasmo, harmonia e originalidade e número de componentes - que pontuavam igualmente entre 50 a 20 pontos.

Não se deve esquecer que as torcidas uniformizadas eram compostas pelos sócios dos clubes pertencentes aos setores elitistas da sociedade. Assim, caberia às classes abastadas economicamente e com influência política ensinar para a massa torcedora a nação idealizada pelo Estado Novo.

Essa nação deveria ser disciplinada e organizada para o trabalho e bem estar coletivo, onde as diferentes classes sociais conviveriam harmonicamente. Assim, a nação ideal seria um reflexo da torcida uniformizada: elitista, sem conflitos sociais, disciplinada, ordenada e entusiasmada com os deveres cívicos, em prol do coletivo. 


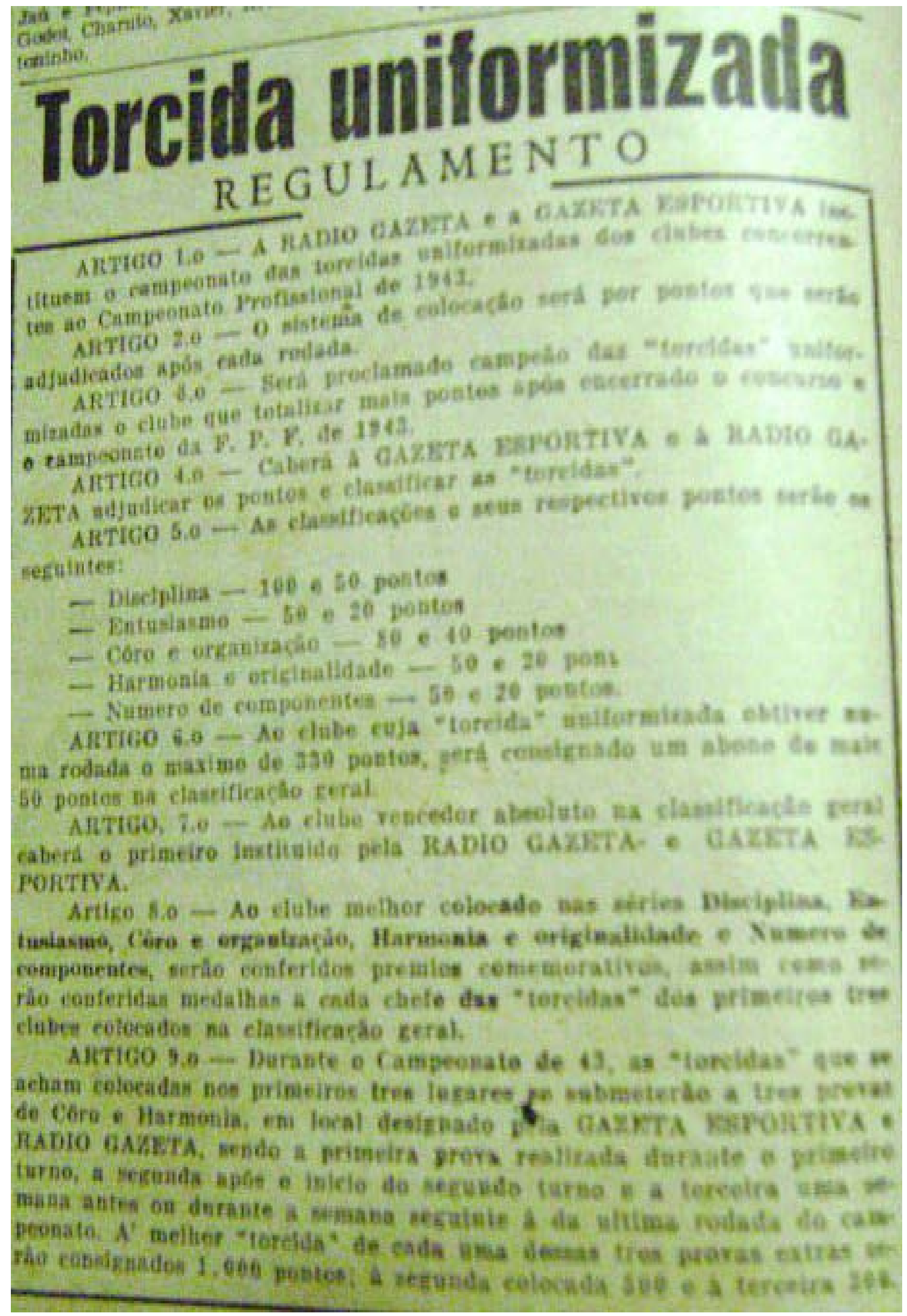

Regulamento do concurso para eleger a melhor torcida uniformizada de São Paulo, cujos principais critérios eram afins com os principais valores estadonovistas: disciplina, entusiasmo para o trabalho, organização, harmonia e coletividade. Gazeta Esportiva, 22 de março de 1943, p. 4. 


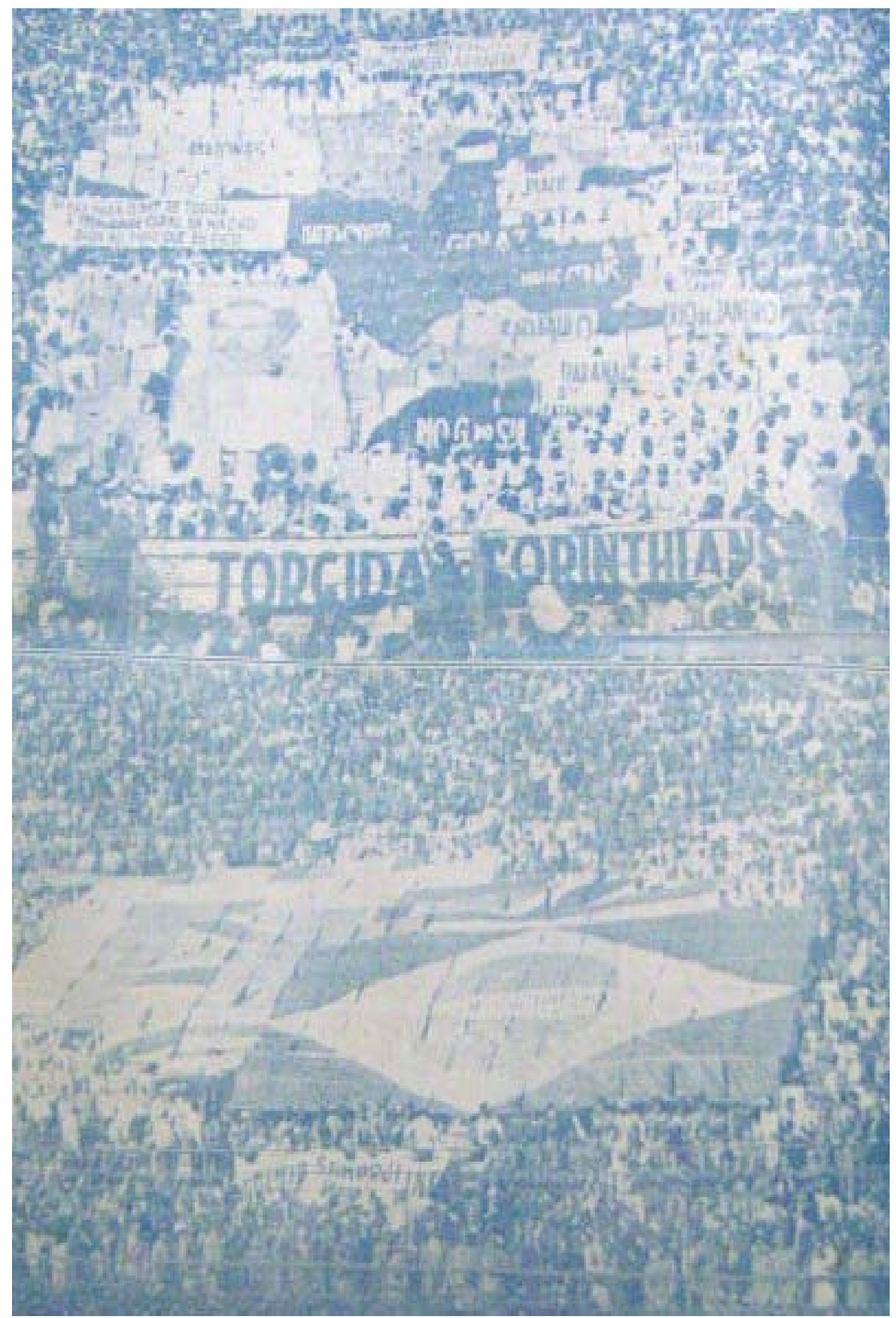

Foto da torcida uniformizada do Corinthians e do São Paulo. A presença do símbolo pátrio, representado pela bandeira nacional, do mapa brasileiro formado por seus estados e da foto de um dos ídolos do panteão nacional, D. Pedro I, afirmam a concepção do jogo de futebol como uma aula cívica para a massa. Gazeta Esportiva, 11 de setembro de 1943, p. 10. 


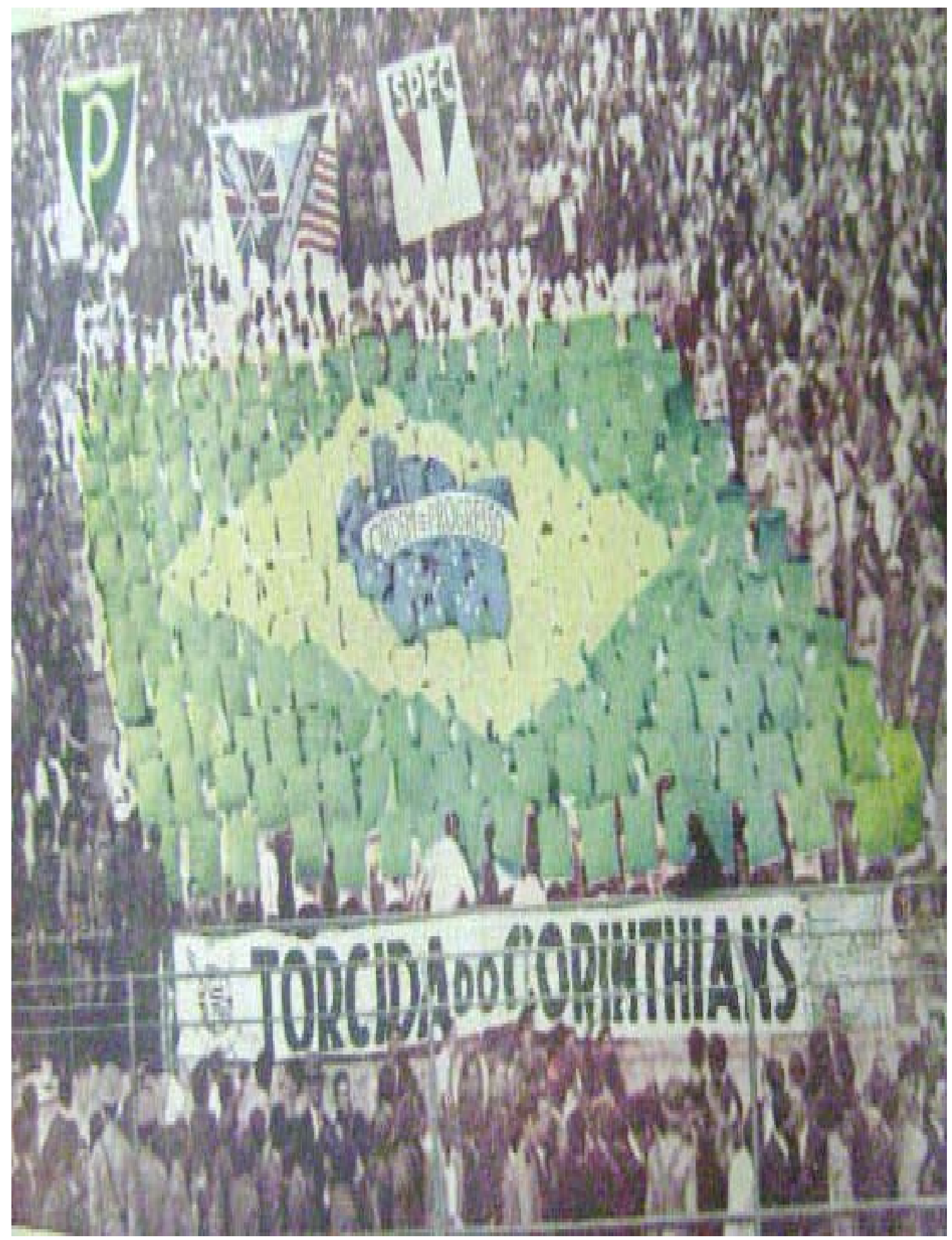

Torcida uniformizada corinthiana em ação. Nessa foto percebe-se, além da formação da bandeira nacional, a presença dos símbolos dos três grandes clubes paulistas em harmonia, na mesma torcida. Além disso, vale destacar uma separação existente entre os aficcionados: na arquibancada ficavam os torcedores uniformizados, provenientes dos setores elitistas e, abaixo, encontravam-se os torcedores comuns, representantes da massa. Gazeta Esportiva, 19 de junho de 1943, p. 11. 
Para homenagear o interventor federal em São Paulo, Fernando Costa, quando esse visitou o clube Corinthians Paulista, a torcida uniformizada corinthiana realizou uma apresentação em afinidade com os ideais cívicos projetados pelo regime, conforme noticiou a Gazeta Esportiva:

"O programa teve prosseguimento com a apresentação da torcida uniformizada corintiana que proporcionou a s. excia o ensejo de assistir à formação do mapa do Estado de São Paulo, tendo ao centro o grande retrato do interventor federal e a seguir a bandeira do Brasil!? 322

Ao analisar a notícia, pode-se perceber a ideologia nacionalista enraizada no cotidiano da sociedade. A formação de um conjunto disciplinado e harmônico embasava a torcida que exaltava os valores nacionais defendidos pelo Estado. Além disso, a sequência das imagens montadas pela massa retirava toda a rebeldia que essas poderiam causar, pois colocava São Paulo como um estado subordinado à União.

Nesse contexto, os concursos para a melhor torcida uniformizada representavam a padronização do corpus social posta em prática pelo Estado Novo na formatação de uma nação unida e organizada disciplinadamente.

${ }^{322}$ Gazeta Esportiva, 6 de agosto de 1945, p. 11. 


\section{Expressiva homienagen civica do esporte à Reipublica}

Incarnando os sentimentos gerais dos esportistas bandeirantes, ha pouco, a Torcida Uniformizada do Esporte Clube Corintians Paulista apresentou esse magistral trabalho coreografico, que repr esenta o escudo republicano nacional

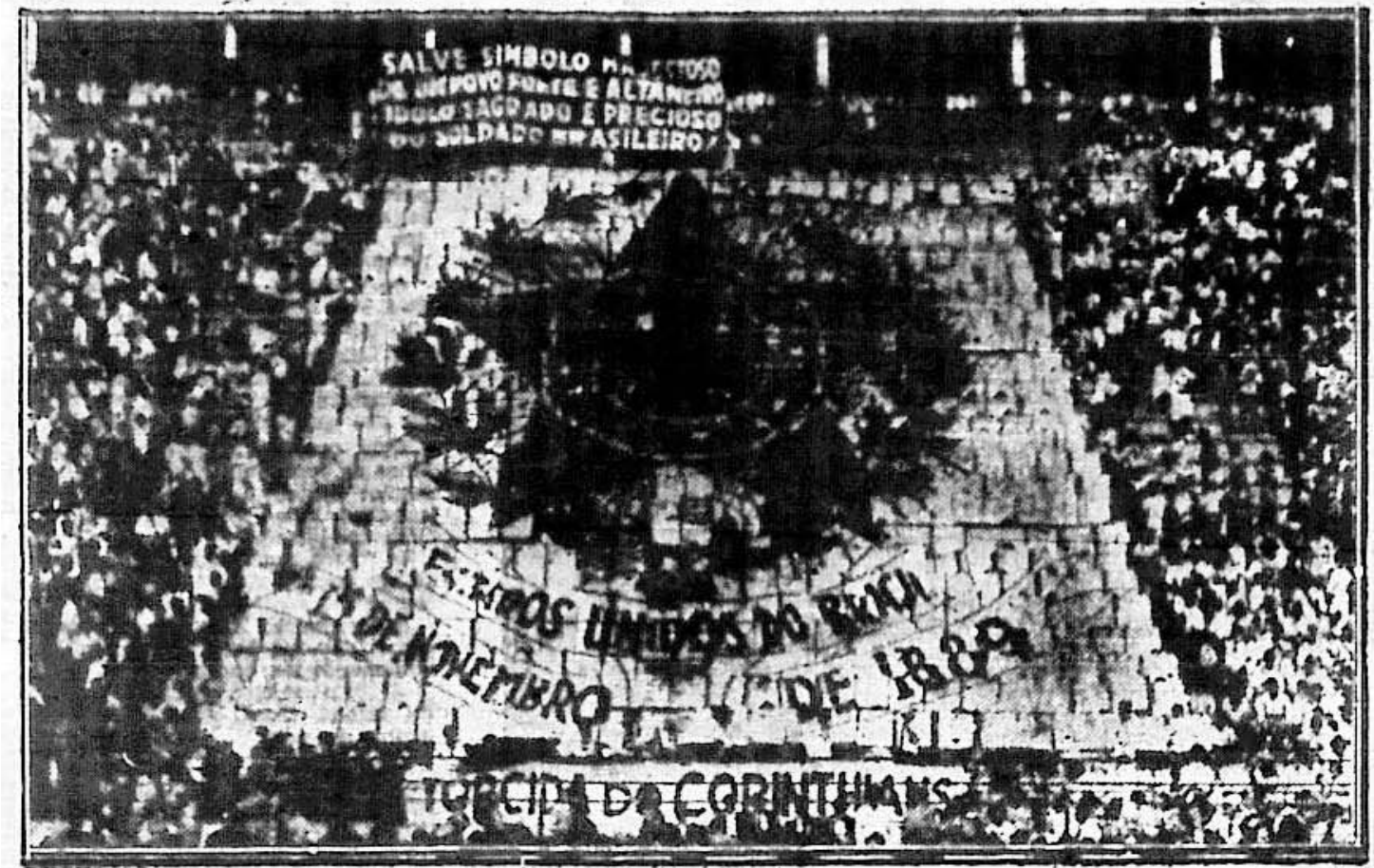

ESPQRTE E CIVISMO : Ela al a formula que con- Umento patriotlco desperta na gente o nentido exato da cilla toda uma grande attridado do homem, reavivando- | disciplina na conquista de laurels quo ateatem o valor de conting das uma Patris. Tho o. vaior flatco-moral denira da pratica comtinua das uma Patris. da Mda, qualquer que seja o selor que lhe seja atribardo.

0 homem sempre teve. neceasidade do maximo-de suas forcas, para emprega-lad no movimento normal do suan proptias atividades, enfrentanto os demain
tón da Natureza, como o rel natural dos animais

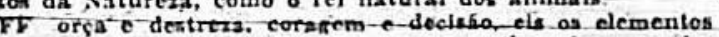
de quo senspre prectsou usar para o melhor desempenho de suns tarelan, dende o primituvismo de oun Idade nos tempos modernos de rida-e-de-lutar

o eaporte educa muscules, disciplina vontades o infundo confirnga proprla, norteando o homem para unia alliude humara de irmanasio de todoa os Individuon.

o homem forte nfo of aperias aquele que expse a rohuatez do seu fislcó to trabalho exaustivo de grandes e petindas eargas... Preclo so torna qut ele Alsponha, tambem, do uma vontade dominada, de uma compreensío dos zberts e de uma sengatez lucidas pars a compre

o esporte, nessa cruzada de preptarar o homem parn

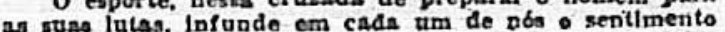
patrlo, preparando nervoa museulos, entrozando von. tadea o ulaclplina para que surla uma raca forto firme na deleas da. Patrin

Nine futas a qua nos temos envolvido no terrenó do

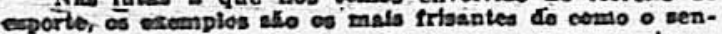
de homens viu erólet-se ufana no mastaréa dn giorla a Bandelra do Brasil. que a habillade do lenente paranaenco fora.buscar dentro as démals. a emoçís invadro od.as os peltos, no sentir de perto os acordes do hino na coral, niquele maxestoso Estadio.. Em Lima. no celehrado campeonato bul-amricano de atleilomo, aqueles gtuapos rapazea so emoclonaram ds ingrimas guando a nossa bandeira fol Icada viforlosamente a mastro de hohra:

Sha passageng que flagrantliam o. valor o a cortit-

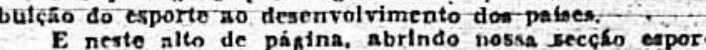
Uva nesle dia dos mals festiyos para a Branil, estampamos hofe um aspecto da expreksiva homenageen com que os exportes bandeirantes saudaram a Republica.

- Tase espetaculo coreografico coube a glorloso Fipporte Clube Cortntlans Paultsta, qtando ha podco, na Jornada thal oo cen concurso "sne renerls" ". Torclda Unlformirado rorlntana dirlelda pelo eapirito ldeallata de Ca sanosa, apresenton o emblemn da Republica.

Eepetnculo grandioso, por certo, que bem expreasou o Eepetnculo grandioso, por certo, que bem expressou o ecritimento eivico do pabllco bandelranie pela repubilca, quo teve em solo pauhata a gua base de granito. rem, neste Impresslonante trabalho de esfesço de suerri:

Torcida uniformizada do Corinthians realizando sua performance cívica ao formar o símbolo republicano da nação para comemorar a proclamação da república. Nesse sentido, percebe-se São Paulo, na performance da torcida corinthiana, se curvando à União. Na notícia destacou-se o seguinte trecho que reafirmava a função do esporte de ensinar à massa os ideais nacionais projetados pelo Estado Novo: "O esporte nessa cruzada de preparar o homem para as lutas, infunde em cada um de nós o sentimento pátrio, preparando nervos e músculos, entrozando vontades e disciplina para que surja uma raça forte, firme na defesa da Pátria” Correio Paulistano, 15 de novembro de 1944, p. 10. 
Para que os torcedores como massa não deixassem de representar suas expectativas individuais e se transformassem em algo grandioso e potencialmente perigoso, deveria o governo autoritário controlá-los ao máximo, transformando a massa em elemento amórfico.

A própria Educação Física foi valorizada pelo Estado Novo e imposta como matéria básica nos colégios do período por ser capaz de disciplinar a força do cidadão, cuidar de sua saúde, desenvolver suas habilidades e voltá-lo ao trabalho. Nesse sentido, o futebol auxiliava a moldar o homem nacional engendrado pelo governo estadonovista, pois quando praticado disciplinadamente fazia os individualismos se solidarizarem em favor do bem comum e da vitória do conjunto.

Os ideais de eugenia e disciplinarização do corpo para o trabalho estavam presentes na edificação do maior complexo poliesportivo das Américas, cuja função era ser um espaço para recreação e civismo ${ }^{323}$. Desse modo, a construção do estádio do Pacaembu demonstrou o embricamento entre política e futebol no período, constituindoo como monumento público legitimador do Estado Novo:

\footnotetext{
"Podemos considerá-lo [o Pacaembu] como um monumento que traduz a própria síntese dos anos 30 e dos anos seguintes, pois esse estádio term a sua construção efetivada num momento de extrema valorização das atividades físicas e das manifestações cívicas envolvendo multidões. Ao mesmo tempo, ocorre a sendimentação do futebol profissional dentro de uma cidade em processo de metropolização” ${ }^{324}$.
}

\footnotetext{
${ }^{323}$ NEGREIROS, Plínio José Labriola de Campos. Op. cit., p. 148.

${ }^{324}$ Idem. Ibidem. p. 126.
} 


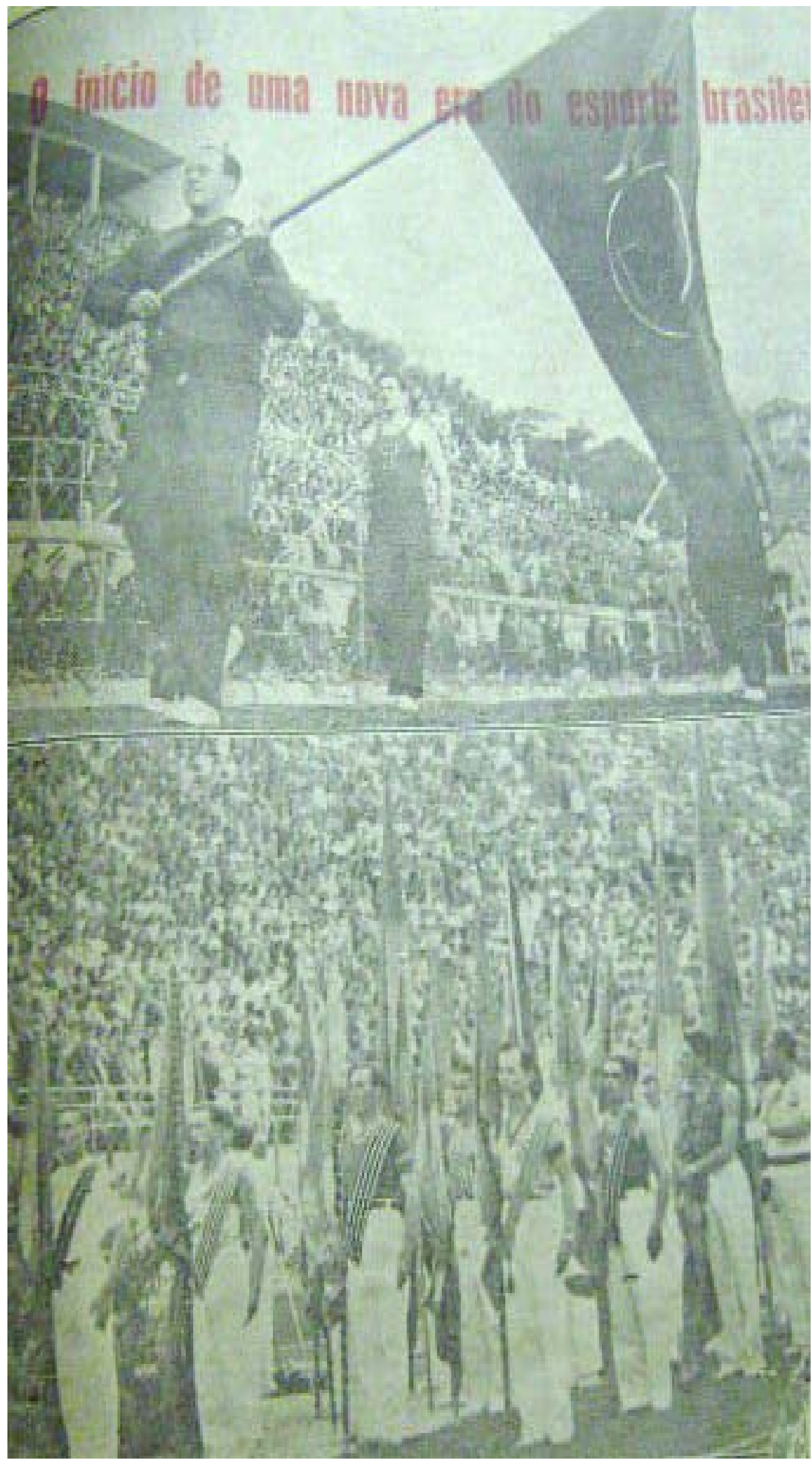

Desfile cívico assistido por milhares de pessoas durante a inauguração do Pacaembu. Gazeta Esportiva, 22 de abril de 1940, p. 6. 


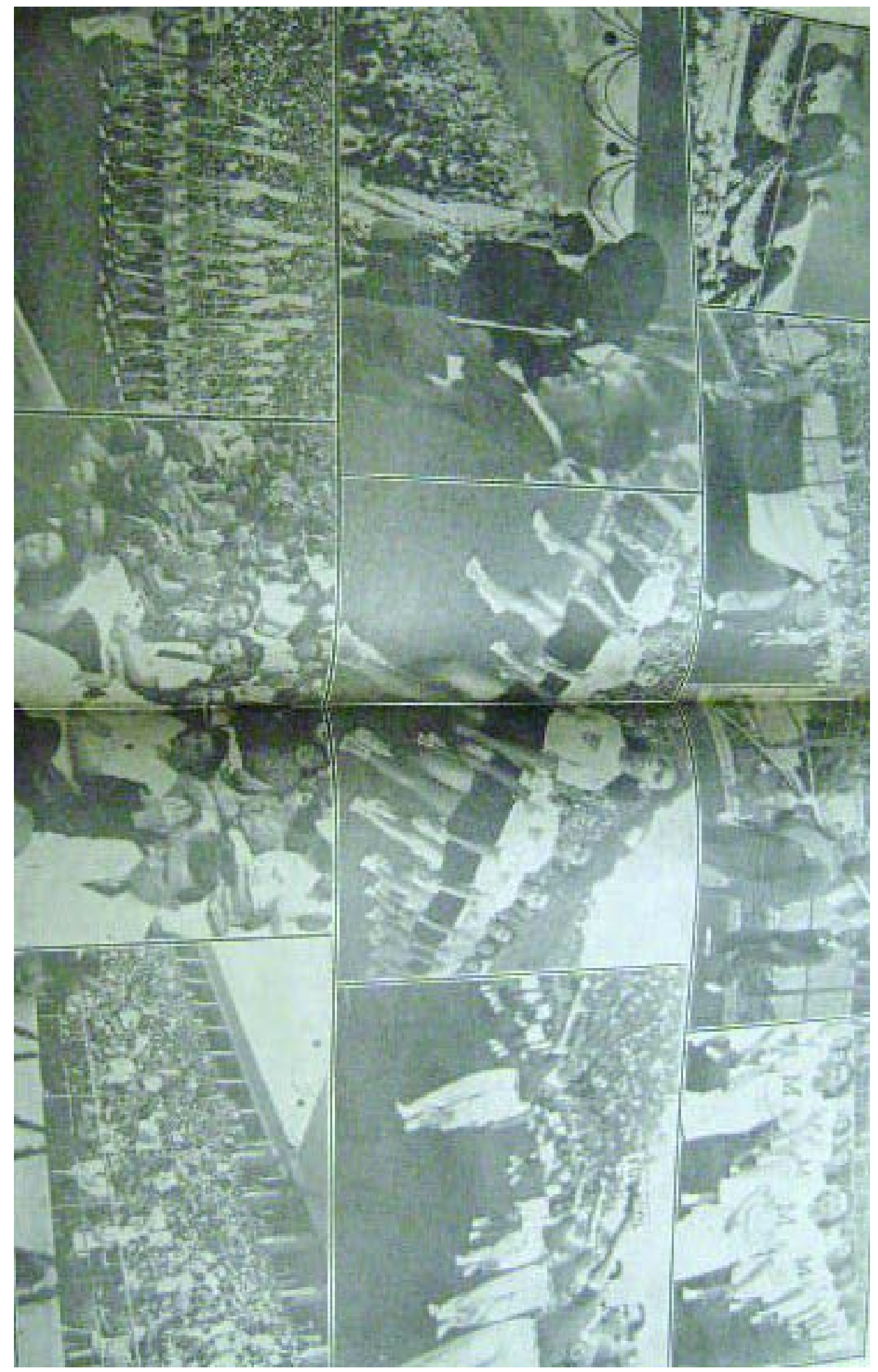

Imagens da cerimônia de inauguração do Pacaembu nas quais nota-se a presença de vários políticos assistindo à cerimônia, ao desfile realizado por colegiais nos moldes do regime (de maneira disciplinada, ordeira e harmônica) e a grande presença do público para a aula de civismo. Gazeta Esportiva, 29 de abril de 1940, p. 8-9. 


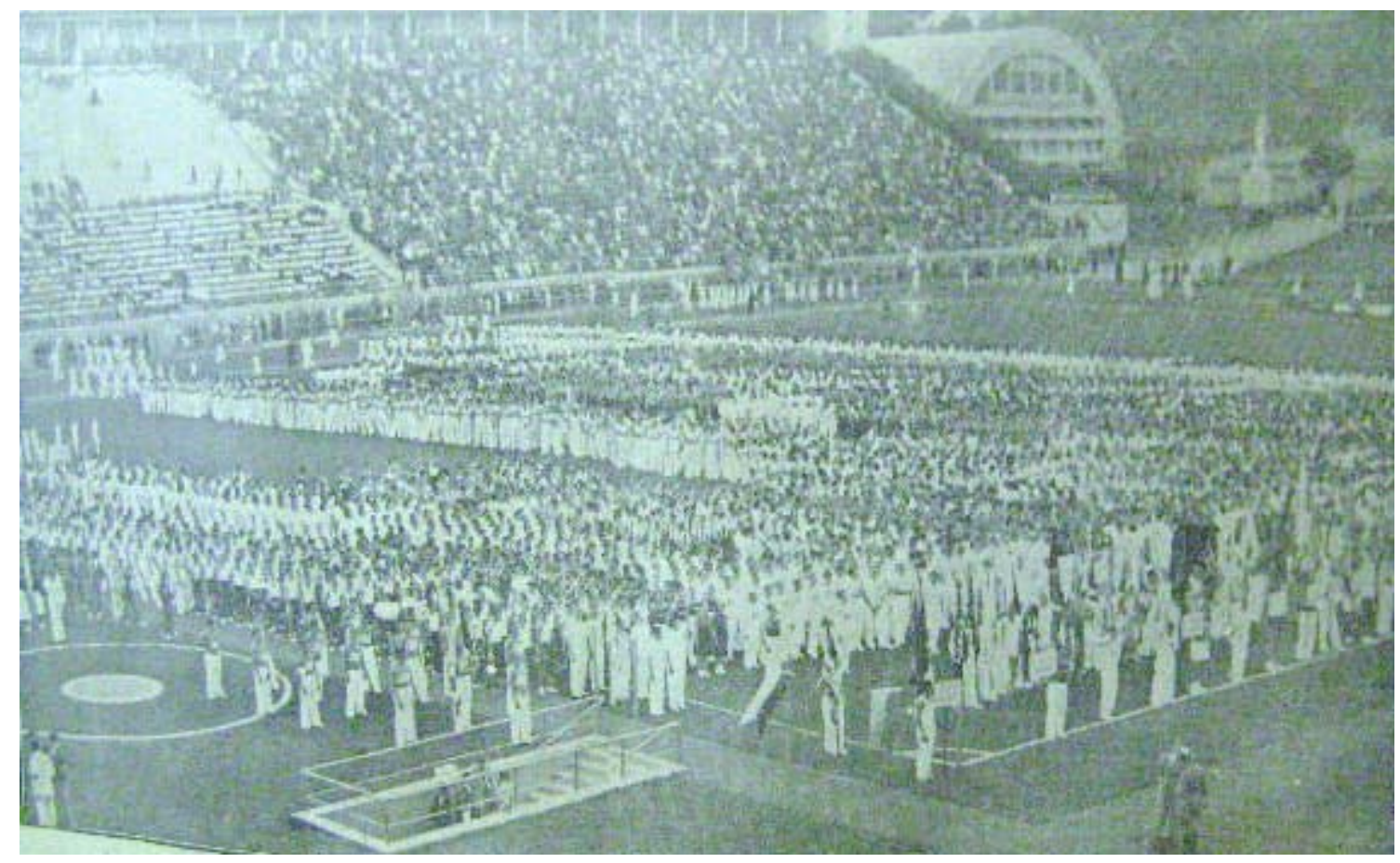

Foto panorâmica da cerimônia inaugural do Pacaembu notando-se a ordem e disciplina da coletividade harmônica. Gazeta Esportiva, 29 de abril de 1940, p. 16.

Sobre a construção de momumentos para ordenar a sociedade em regimes

autoritários, Bourdieu escreveu:

“Talvez seja refletindo sobre o que o esporte tem de mais específico, isto é, a manipulação regrada do corpo, sobre o fato de o esporte, como todas as disciplinas, em todas as instituições totais ou totalitárias, os conventos, as prisões, os asilos, os partidos, etc., ser uma maneira de obter do corpo uma adesão que o espírito poderia recusar, que se conseguiria compreender melhor o uso que a maior parte dos regimes autoritários faz do esporte (...) Assim se explica o lugar destinado por todos os regimes de caráter totalitário as práticas corporais coletivas que, simbolizando o social, contribuem para somatizá-lo e que, pela mimesis corporal e coletiva da orquestração social, visam a reforçar essa orquestração" ${ }^{325}$.

Nesse contexto, o sentido cívico do Pacaembu foi analisado por Negreiros da seguinte forma:

${ }^{325}$ BOURDIEU, Pierre. Programa para uma sociologia do esporte. IN: BOURDIEU, Pierre. Coisas ditas. São Paulo: Ed. Brasiliense, 2004. p. 220. 
“... as atividades esportivas - ou mais amplarmente, as atividades físicas e artísticas - deveriam estar intimamente vinculadas às manifestações de civismo. Assim, mais uma vez tinham como objetivo colaborar na construção do 'novo brasileiro'. Ele precisava ser forte para defender a nação; porém, também precisava compreender porquê era necessário defender o Brasil. Daí a união perfeita entre as atividades físicas e as práticas cívicas” ${ }^{326}$.

A edificação do Pacaembu realizada nas bases estadonovistas da disciplina, ordem e uniformidade tinha o objetivo de afirmar São Paulo frente aos demais estados da federação e demais países americanos. Nesse sentido, compreende-se a escolha arquitetônica e do material utilizado na construção que lembrava concreto armado pois, na época, esses elementos simbolizavam requinte e modernidade, além de conferir uma imagem monumental ao estádio.

Em sua inauguração grandiosa ocorrida na data de aniversário do interventor paulista, Adhemar de Barros, todos os detalhes foram pensados para demonstrar a supremacia paulista e seu papel de destaque na construção da nacionalidade brasileira:

“... estava em jogo muito mais do que uma simples organização de uma praça esportiva; através do esporte, São Paulo se afirmaria frente ao Brasil e o resto da América. Portanto, daí a necessidade de uma massa uniformizada e disciplinada. Em última instância, assim deveria ser o país. Ou seja, no dia da sua inauguração, o Estádio do Pacaembu deveria apresentar-se como os dirigentes do Estado Novo desejavam que o Brasil fosse” ${ }^{327}$.

A presença de delegações provenientes de países estrangeiros justifica-se pelo desejo em demonstrar ao mundo a força da nação brasileira, enquanto o desfile de estudantes de cento e oitenta diferentes municípios reforçava a unidade nacional

\footnotetext{
${ }^{326}$ NEGREIROS, Plínio José Labriola de Campos. Op. cit., p. 134.

${ }^{327}$ Idem. Ibidem. p. 148.
} 
interna $^{328}$

Diversas competições esportivas foram programadas, porém a de maior destaque foi a futebolítistica, na qual disputaram clubes de quatro diferentes estados: Flamengo (Rio de Janeiro), Corinthians (São Paulo), Atlético (Minas Gerais) e Curitiba (Paraná). A ausência de clubes estrangeiros no torneio e a presença de times fora do circuito Rio - São Paulo foram ao encontro dos valores de união nacional propagados pelo Estado Novo.

No discurso inaugural proclamado por Vargas e publicado na Gazeta de Notícias, em abril de 1940, destaca-se o seguinte trecho:

"Deante dessa demonstração da mocidade forte e vibrante [desfile de dez mil atletas com as cores nacionais], índice eugênico da raça (...) Povo de São Paulo! (...) Comprehendestes ainda que este monumento é como um marco da grandeza de São Paulo a serviço do Brasil” ${ }^{329}$.

É notável, pelo discurso, a preocupação de Vargas em construir uma nação eugênica e disciplinada quando este destaca a figura da juventude sadia e perfilada harmonicamente durante o desfile. Outro fator relevante consiste na necessidade em subjulgar o estado de São Paulo e colocá-lo a serviço da nação, retirando toda a ameaça que o poderio político-econômico paulista poderia causar à hegemonia estadonovista.

Desse modo, construiu-se no período do Estado Novo a noção de ser um

\footnotetext{
${ }^{328}$ De acordo com Negreiros, os treinos promovidos para o desfile de inauguração do Pacaembu foram bastante rígidos, pois esse deveria ser perfeito. Se os clubes não comparecessem no treinamento, eram punidos e arriscavam ficar sem o alvará para o funcionamento, expedido pela Diretoria de Esportes, comandada pelo tenente Sylvio Magalhães Padilha. NEGREIROS, Plínio José Labriola de Campos. Op. cit., p. 157.

${ }^{329}$ Gazeta de Notícias, 28 de abril de 1940, p. 16.
} 
cidadão aquele que torce pela realização da nação, sendo essa última vislumbrada pelos ideais elitistas e autoritários concebidos pelo regime. Ao futebol caberia representar, em pequena escala, a sociedade idealizada pelo governo sendo sua prática como espetáculo, e seus atores como agentes sociais responsáveis em orientar a massa torcedora para a concretização dessa idealização na macro esfera. 


\subsection{Contra-Ataques Imprevistos}

Os meios autoritários, coercitivos e censores impostos pelo Estado Novo para moldar e controlar a sociedade e o futebol em favor da realização de seus interesses encontraram, em certos momentos de tensão e conflito, oposição por parte de alguns setores sociais. Apesar de esses contra-ataques terem sido combatidos violentamente pelo regime autoritário, certamente eles contribuiram para o fim do Estado Novo e evolução do processo de democratização da sociedade brasileira.

Inúmeras notícias sobre rebeldia dos jogadores de futebol eram publicadas nos periódicos em um momento em que toda a imprensa esportiva destacava a parte disciplinar do time e do próprio jogo, afim com os paradigmas ditatoriais. A prática rebelde desses jogadores destacava suas individualidades em um contexto em que era valorizada a harmonia do conjunto, seja do time ou da nação.

A prática rebelde desses jogadores era um mau exemplo para a massa torcedora e deveria ser fortemente criticada pela imprensa. Assim, criticavam-se casos de jogadores rebeldes dentro e fora de campo, atletas contrariando dirigentes de clubes e práticas de não obediência às regras dentro da concentração da seleção brasileira. Em contrapartida, exaltavam-se os casos de redenção de jogadores considerados, anteriormente, como problemáticos.

Sobre jogadores indisciplinados, destaca-se a notícia sobre a briga entre o jogador Carreiro e seu técnico no São Cristovão, Adhemar Pimenta:

\footnotetext{
“Ao se defrontar com Pimenta, Carreiro dirigiu-lhe palavras pouco amáveis. O dirigente do quadro evitou discutir, mas quasi se estabeleceu uma scena de pugilato. Intervieram outros
} 


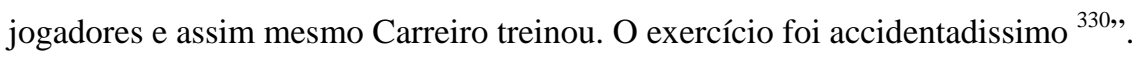

Como punição, a diretoria do clube suspendeu o jogador por trinta dias e o multou em um ordenado no valor de $800 \$ 000$. O final desse episódio demostrou o alinhamento existente entre o pensamento da elite dirigente do futebol e do governo estadonovista: ambos não suportavam atos de rebeldia e repudiavam as ações que poderiam estragar a harmonia do conjunto e desafiar a autoridade do chefe.

O mesmo pensamento autoritário estava presente no autor da matéria. Seu inconformismo por Carreiro ter voltado a treinar, mesmo após ter realizado tão graves atitudes, demonstrou como eram fortes as noções de ordem e de chefia na sociedade do período.

Por outro lado, quando um jogador rebelde ficava arrependido dos seus atos passados e entrava em sintonia com os valores da disciplina, ordem e harmonia em prol do conjunto, os jornalistas logo enalteciam sua nova conduta. A mudança de atitude ocorrida no zagueiro Agostinho foi noticiada pela Gazeta Esportiva:

\footnotetext{
"Época houve, é verdade, que o acoimavam de indisciplinado, de elemento provocador de dissidências em campo. Entretanto, necessário se tornava que os seus detratores procurassem averiguar o motivo das atitudes por ele assumidas, Para agir assim deveria existir algo. Coisas internas, é verdade, mas que acabavam por refletir em campo. (...) O fato é, porém, que nos dias presentes Agostinho tem honrado seu alto posto, dando frizantes exemplos de comportamento. É um futebolista profissional correto" ${ }^{331}$.
}

Na opinião do jornalista paulista, um legítimo profissional do futebol deveria seguir os valores elitistas presentes nesse esporte desde a sua época amadora, ou seja, precisava comportar-se como um sportman, com disciplina, lealdade e harmonia.

\footnotetext{
${ }^{330}$ Jornal dos Sports, 7 de janeiro de 1938, p. 4.

${ }^{331}$ Gazeta Esportiva, 19 de julho de 1941, p. 6.
} 
Para a realização dos projetos estadonovistas, visando à construção de uma nação unida e harmônica, a rebeldia projetada à sociedade pelo futebol era muito prejudicial. Esse esporte deveria ser um exemplo de disciplina, coletivismo e nacionalismo para a massa torcedora e, por isso, foi tão controlado e propagandeado pelo governo varguista, conforme visto anteriormente.

Outra prática considerada subversiva pelo Estado Novo, pois contrariava seus princípios eugênicos de nação, era o futebol feminino. Afim com a ideologia machista presente na sociedade, os periódicos esportivos firmavam a ideia de ser boa a presença feminina somente como espectadoras do jogo, pois estariam enfeitando um esporte violento como futebol, com a sua graça e feminilidade.

Em um primeiro momento, essa torcida feminina era formada por membros da elite mas, com a profissionalização desse esporte, mulheres provenientes das classes populares igualmente encontraram no esporte uma forma de lazer:

\footnotetext{
“À medida que o futebol se popularizava, porém, a aristocracia deixava os estádios, levando consigo suas filhas e, em muitos casos, também os filhos. Mudavam os jogadores, que passaram a entrar em campo graças ao talento e não ao sobrenome, mudava também o público, que agora freqüentava mais os galpões das fábricas que os seletos salões de baile dos clubes. Nem por isso as mulheres, ainda que outras mulheres, deixaram de acompanhar o futebol, como mostra a presença das jovens Miquelina e Iolanda nas arquibancadas do Parque Antarctica, assistindo à vitória do Corinthians sobre o Palestra no conto de Antônio de Alcântara Machado chamado justamente “Corinthians (2) x Palestra (1)”.10 Escrito na década de 1920, o texto demonstra à perfeição como o elitismo e seus bons modos perdiam de vez seu lugar no futebol para a alegria e a vibração populares, com o apelo da bola tornando-se abrangente a ponto de o autor, mesmo na ficção, fazer daquelas torcedoras suas personagens principais”332.
}

\footnotetext{
${ }^{332}$ FRANZINI, Fábio. “Futebol é ‘coisa para macho’? Pequeno esboço para uma história das mulheres no país do futebol”. Revista Brasileira de História. São Paulo, vol. 25, nº 50, pp. 315-328, 2005. pp. 318319.
} 
Nos subúrbios da capital fluminense estavam localizados os principais clubes de futebol feminino, como Eva F. C., o E. C. Brasileiro, o Cassino Realengo e o Benfica F. C. A estrutura e popularidade desses clubes eram tão precárias que o Primavera F. C. contratava suas jogadoras por classificados publicados nos jornais ${ }^{333}$.

Graças à presença desses clubes, o futebol feminino era considerado pela crônica esportiva paulista como uma “invenção carioca”. Como a ideia presente na época era de que o estado que fomentasse a sua prática não estaria trabalhando em prol da nação, o futebol feminino acentuava o conflito futebolístico entre os estados de São Paulo e Rio de Janeiro.

Como ressaltou Fábio Franzini, a principal crítica ao futebol feminino realizada durante o Estado Novo, era que ele fazia as mulheres abandonarem suas funções naturais:

"Além do machismo e do moralismo que essas ditas preocupações com o bem-estar das brasileiras não conseguem esconder, elas revelam que, na verdade, o grande problema dizia respeito não ao futebol em si, mas justamente à subversão de papéis promovida pelas jovens que o praticavam, uma vez que elas estariam abandonando suas "funções naturais" para invadirem o espaço dos homens. Não por acaso, o foco do debate centrava-se nos usos que as mulheres faziam de seu próprio corpo, daí derivandose o tema da maternidade. Nos anos 30 e 40, a associação entre o autoritarismo político e as idéias e ideais da eugenia fazia do corpo uma questão de Estado e o colocava na ordem do dia... "334.

Nesse sentido, estuda-se a opinião do médico especialista em medicina esportiva, Leite Castro, sobre a prática do futebol feminino:

"Sob o ponto de vista estético é um contracenso o futebol feminino, assim como encarado pelo lado biológico, é um esporte violento capaz de alterar o equilíbrio endócrino da mulher. Praticado por mulheres só pode ser aplaudido como exhibição grotesca ou teatral ao sabor da curiosidade popular ávida de novidades ou originalidades (...) Ela [a praticante de futebol] evolui para em equilíbrio plástico e orgânico, diante do esporte violento, em detrimento de sua função materna. O que ela ganha como atleta, ela perde como mulher. (...) Apesar da moda social moderna a mulher não pode fugir as suas tendências biológicas inevitáveis, reguladas pela chave endócrina da tireoide e dos ovários. A educação física, os exercícios corporais, o atletismo e como coroamento a natação - eis a boa norma que deve ser seguida pelas moças em geral, a fim de que, possam obter saúde e beleza. Não é no futebol que a juventude feminina se aperfeiçoará. Pelo contrário - é o futebol o esporte que lhe trará defeitos e vícios; alterações

\footnotetext{
${ }^{333}$ Idem. Ibidem, p. 319.

${ }^{334}$ Idem. Ibidem, p. 321.
} 
gerais para a própria fisiologia delicada da mulher, além de outras conseqüências de ordem traumática, podendo comprometer seriamente os órgãos da reprodução (ovário e útero). (...) Para a conquista da beleza e da saúde, bastará, que a mulher fuja dos esportes violentos e se entregue aos exercícios corporais sadios, correndo para os campos e piscinas, a fim de obter harmonia de formas, delicadeza de gestos, correção de atitudes e rigidez orgânica completa para sua felicidade e grandeza de nossa pátria! - conclui o dr. Leite de Castro"” ${ }^{335}$.

De acordo com a opinião médica, o futebol seria o antiesporte para o sexo

feminino, pois a sua prática poderia comprometer os órgãos reprodutivos e prejudicar a maternidade. Assim, ao jogar futebol, as mulheres estariam se afastando da sua principal missão - gerar filhos para a nação em concordância com os valores do regime.

Ainda sobre esse tema, outra interessante matéria foi publicada na Gazeta

\section{Esportiva:}

"Um grupo de divertidas moças cariocas entendeu de jogar futebol. Imitação norte-americana. (...) Da idéia a ação foi coisa de dias. Eis as cariocas dedicando-se a um treinamento severo, com toda a indumentária futebolística, inclusive a treinadora. $\mathrm{O}$ fato espalhou-se pelos quatro cantos da cidade e não faltaram eugenistas a criticar com acerbo a tentativa arrojada. (...) As meninas, contudo, fizeram ouvido ôco as palavras de advertência e continuavam assiduamente os seus treinos, enquanto que, da parte do público a curiosidade pela exibição das moças aumentava enormemente. Veio o jogo - estréia, verdadeira pantominia. A força não poderia ser melhor. Depois, outros jogos, considerados sempre mais pelo lado circense do que propriamente pelo o que eles podiam ter de semelhança com o futebol... Elas jogavam à sua moda... Na ignorância das regras chegavam as vezes aos puxões de cabelos da adversária. Defesa inata das mulheres. Tudo passa, porém, o futebol feminino também passou (...) A treinadora de um dos times organizados não desistiu. Observando que as suas pupilas, como futebolistas eram boas dansarinas [sic], chamou-as e expôs o plano: transformar o 'onze' num grupo de bailarinas (...) As 'cracks', constituídas agora de dansarinas, surgiam nos 'dancings' e 'cabarets' com a mesma indumentária dos campos de futebol: calções curtos, tornozeleiras e chuteiras. A novidade pegou. E o dinheiro vinha... Mas, no melhor da festa a polícia apareceu, truncando os sonhos bonitos das ex-futebolistas. O negocio tinha que terminar assim mesmo. No estado maior das grades. Na delegacia, numa derradeira tentativa de salvação, a treinadora procurou ainda justificar a finalidade do clube: aperfeiçoamento físico da raça... Está conforme!" 336 .

Primeiramente, pode-se analisar o cunho regionalista empregado pelo autor ao

colocar o futebol feminino como algo próprio do Rio de Janeiro. Assim, o jornalista

valorizou, indiretamente, as mulheres paulistas como se apenas essas dessem vida a verdadeiros cidadãos da nação, indivíduos afins com os princípios eugênicos propagados pelo Estado.

\footnotetext{
${ }^{335}$ Gazeta Esportiva, 29 de junho de 1940, p. 10.

${ }^{336}$ Gazeta Esportiva, 16 de janeiro de 1941, p. 5.
} 
Ao afastar o jogo feminino da prática do verdadeiro futebol, o jornalista paulista descaracteriza-o como esporte síntese do ethos nacional. Para ele, esse tipo de futebol aproxima-se do circo e não deveria ser levado a sério.

Ao finalizar a matéria, o jornalista caracterizou as jogadoras como prostitutas e, logo depois, como criminosas. Essas mulheres representavam um mal à nação, pois não respeitaram os valores do regime e sendo assim, de acordo com o jornalista, mereceram ser presas.

Vale destacar a ironia presente no final da matéria, quando o ideal governista de eugenia e de adestramento do corpo para o trabalho pelos esportes apareceu na fala da treinadora presa, quando essa colocou sua atividade como sendo necessária para o aperfeiçoamento físico da raça.

Para regularizar a prática do futebol feminino o Decreto-lei 3.199 que, em abril de 1941 instituiu o Conselho Nacional de Desportos (CND), afirmava em seu artigo 54 que “às mulheres não se permitirá a prática de desportos incompatíveis com as condições de sua natureza devendo, para este efeito, o Conselho Nacional de Desportos baixar as necessárias instruções às entidades desportivas do país” ${ }^{337}$.

Os esportes consideráveis compatíveis à prática feminina, de acordo com o governo estadonovista, tinham o caráter amador e elitista como o tênis, voleibol, críquete, natação e ciclismo (sendo que os dois últimos deveriam ser praticados com moderação) ${ }^{338}$. Assim, para o Estado Novo, o papel da mulher no futebol deveria ser igual a sua função política: assistir aos homens a construir a nação.

\footnotetext{
${ }^{337}$ Cf. FRANZINI, Fábio. Op. cit., p. 322.

${ }^{338}$ FRANZINI, Fábio. loc. cit.
} 


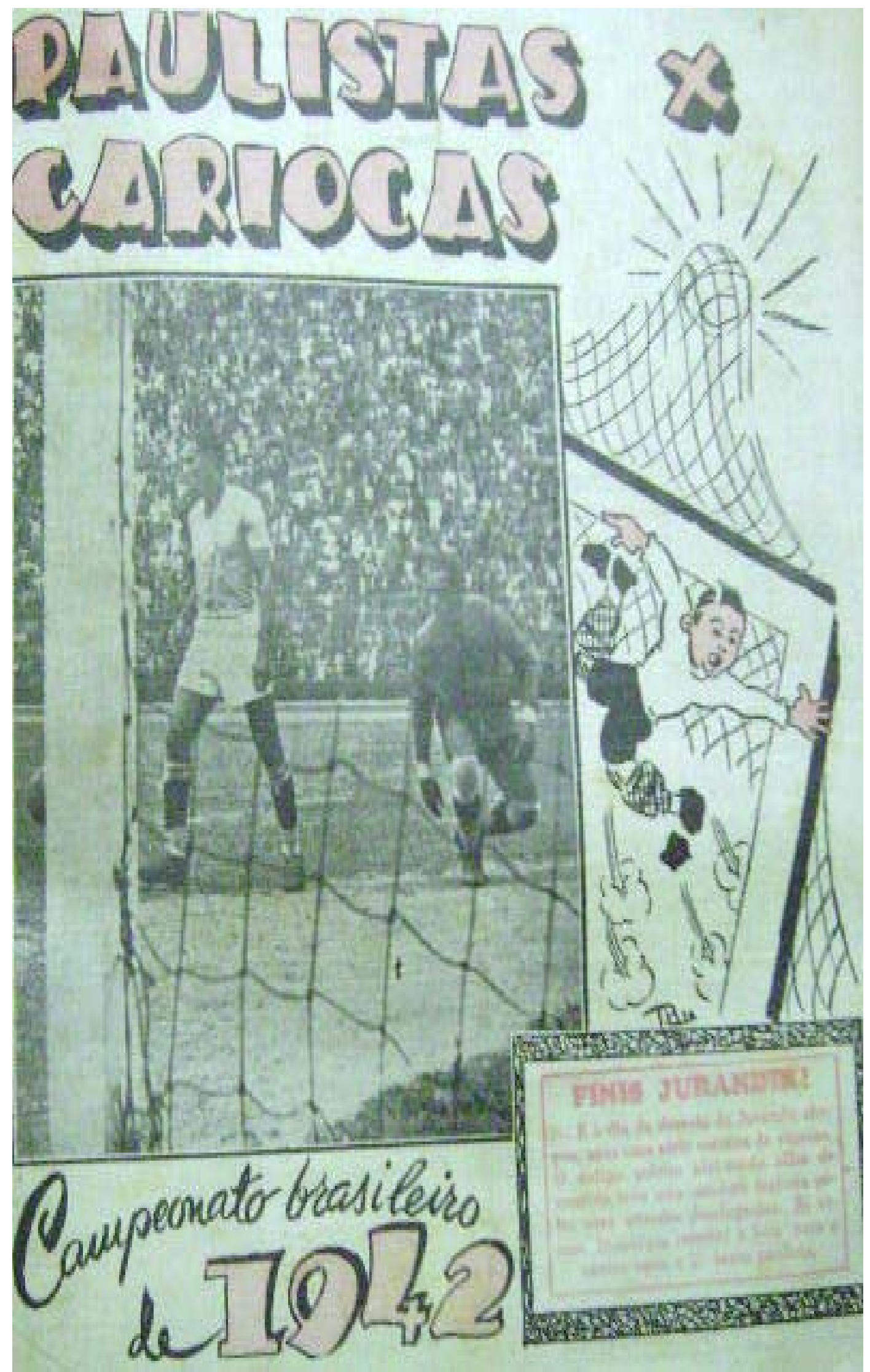

Capa contendo a chamada para o confronto final do Campeonato Brasileiro entre Seleção Paulista versus Seleção Carioca. Gazeta Esportiva, 07 de dezembro de 1942, p. 1. 
Outro grave contra-ataque sentido pelo governo em seu próprio veículo de propaganda era o regionalismo futebolístico entre São Paulo e Rio de Janeiro. Entre as federações carioca e paulista de futebol existiram vários momentos de tensão provocados pelos sentimentos regionalistas. Essas queixas, considerações e provocações regionais escapavam dos censores e, assim, eram publicadas nos periódicos esportivos.

Em 1938, a ida de King goleiro do São Paulo para o Flamengo, sem ter o clube carioca comprado o passe do atleta paulista, transformou-se em um conflito regional agressivo e perigoso para os ideais harmônicos e unitários do Estado Novo.

Graças a esse caso, a Federação Paulista de Futebol anunciou a não concessão de seus jogadores para a formação do selecionado nacional participante do Mundial de Futebol em Paris, alegando recear o arrebatamento de novos elementos pelos clubes cariocas (decisão não levada até o fim, pois os paulistas participaram do campeonato mundial).

Além disso, os paulistas suspenderam os jogos com times do Rio de Janeiro e a Liga de Futebol do Estado de São Paulo ameaçou se desvencilhar da Confederação Brasileira de Desportos. 


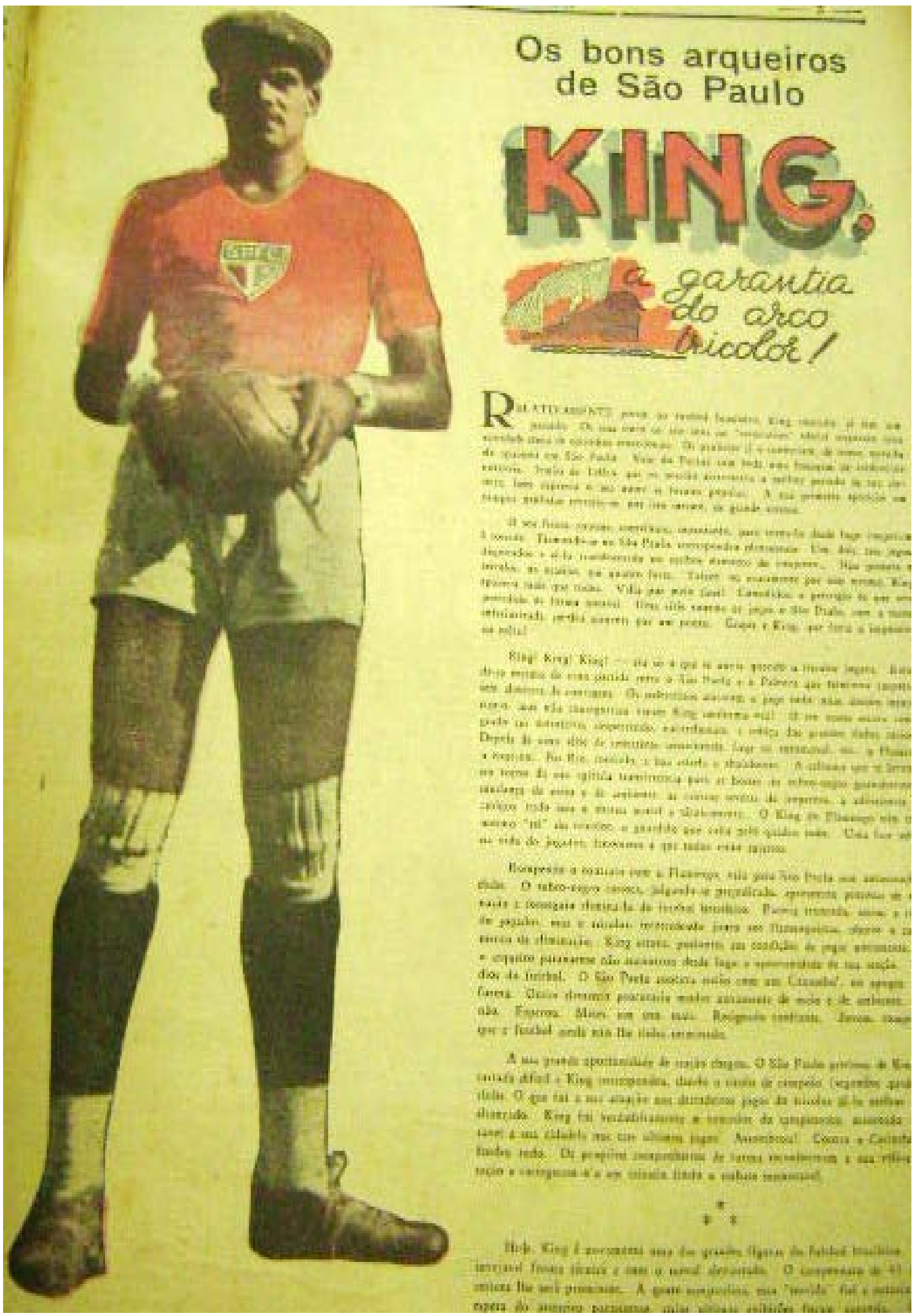

Reportagem sobre a vida de King ocupando toda página. O goleiro teria fugido do São Paulo Futebol Clube para atuar no Flamengo mas, após a intervenção da LPF junto à CBD, King foi obrigado a retornar para o clube tricolor paulista. Gazeta Esportiva, 15 de fevereiro de 1941, p. 3. 
As notícias sobre a transferência do jogador tricolor para o Flamengo

ressaltavam a herança amadora ainda existente no futebol profissional. Desse modo, o caso foi tratado com intensidade nos periódicos esportivos de São Paulo e do Rio de Janeiro:

\begin{abstract}
“Tende a complicar a relação entre os clubes paulistas e cariocas, com o caso do aliciamento de King, pelo Flamengo. Esse caso, attentatorio aos bons princípios de moralidade e cortesia, veio por em foco a mentalidade de certos clubes do Rio que, sem o menor respeito pelos direitos alheios saltam por cima dos regulamentos e compromissos para satisfazer unicamente as suas ambições mesquinhas. Existe um grande movimento de opinião em S Paulo para que os nossos clubes rompam com os da Liga do Rio diante do caso King, uma vez que os demais companheiros do Flamengo estão ajudando-o a mover a politicagem do futebol brasileiro com o indispensável intuito de encampar semelhante bandalheira esportiva”339.
\end{abstract}

\begin{abstract}
"Verifica-se, então, que o intuito do S Paulo foi o de transformar um caso banal de transferência de jogador em um caso político. Essa era a arma predilecta das entidades durante a phase do dissidio. Agora, porém, não comprehendemos a inversão de papéis. O momento não comporta, evidentemente, casos políticos mesmo se se [sic] tratasse da Liga de Foot-ball do Rio de Janeiro, a entidade mais poderosa da Federação Brasileira, não se admittiria que o dirigente de football cedesse a uma injucção (...) Não se admitte que um club, tendo elementos de prova, documentos esmagadores, prefira alimentar uma situação de mal estar (...) Torna-se, porém, indispensável a apresentação de provas, mesmo porque se conhece o falso profissionalismo da maioria dos clubs paulistas" ${ }^{340}$.

Primeiramente, é necessário um esclarecimento do assunto tratado na reportagem. O jogador King alegava que podia sair do São Paulo a qualquer momento porque estava registrado como amador na Liga de Futebol do Estado de São Paulo. Porém, tanto o clube como a entidade paulista negavam essa afirmação e o
\end{abstract} confirmavam como jogador profissional.

Sendo assim, o jornalista carioca insultou o futebol paulista ao classificá-lo como amador e, ironicamente, ao se indagar sobre as provas do profissionalismo de King, insinuou a inexistência dessas. Além disso, a narrativa destacou a supremacia futebolística do Rio de Janeiro e exaltou a sua influência junto às entidades reguladoras do futebol brasileiro.

A imprensa paulista aproveitou-se do caso para acusar os clubes e as entidades

\footnotetext{
${ }^{339}$ Correio Paulistano, 20 de janeiro de 1938, p. 10.

340 Jornal dos Sports, 15 de janeiro de 1938, p. 2.
} 
cariocas de serem protegidos pela Federação Brasileira de Futebol, a fim de diminuir a influência desses e aumentar o poder político do futebol paulista.

Nessa outra reportagem, os clubes cariocas igualmente foram apresentados como instituições alheias às regras e normatizações nacionais, como se a proximidade geográfica deles com as entidades regularizadoras dos esportes nacionais os conferissem impunidade:

“É bem possível que São Paulo esportivo se venha a afastar do convívio official do futebol brasileiro, e o caso toma a cada momento uma feição mais grave. Não é de hoje que os clubes cariocas, sem a menor semcerimônia pelas leis e regulamentos, vêm buscar os jogadores profissionais de São Paulo. Quando os clubes paulistas reclamam e vão pedir justiça aos poderes esportivos, já encontra de atalaia toda a politicagem capadocia dos elementos guanabarinos, que procuram por vários modos, dar uma 'SOLUÇÃO CARIOCA' ao caso, qualquer elle seja! (...) o Conselho de Fundadores da Liga de Futebol do Estado de São Paulo, resolveu: a) - Em signal de protesto dos clubes paulistas, que fiquem suspensos todos os jogos do mesmo com os grêmios cariocas até que se esclareça a situação dos jogadores de São Paulo em relação à Federação Brasileira de Futebol; b) - Conceder plenos poderes ao presidente da Liga de Futebol do Estado de São Paulo, para a mesma agir na defesa dos justos interesses dos clubes filiados, inclusive pedir desfiliação da Federação Brasileira de Futebol; c) - Officiar à Confederação Brasileira de Desportos solicitando informações sobre qual será a situação da Liga de Futebol do Estado de São Paulo, se esta se desfiliar da Federação Brasileira, em face dos factos assignalados com o Vasco, Botafogo e Confederação Brasileira. Pelo que sabemos e ouvimos, não nos surpreenderá se se der o afastamento da entidade paulista do seio do futebol official. Afinal de contas, se é para se resolver vesgamente os casos esportivos sempre com o propósito manifestado de se amparar os clubes cariocas, o que nos adeanta pertencer às entidades nacionaes?” ${ }^{341}$.

O jornalista paulista criticou a parcialidade das instituições reguladoras do

futebol sempre favorável ao futebol carioca. Para o autor do texto, a proximidade regional existente entre os clubes cariocas e essas instituições, ambas sediadas no Rio de Janeiro, possibilitava a formação de um grupo político contrário aos interesses paulistas.

A notícia deixou expressa a visão da liga paulista de futebol de que a união dos clubes cariocas com as entidades futebolísticas trazia um maior poder aos primeiros, deixando-os acima das leis e regulamentos e, por isso, deveria ser severamente combatida pelos dirigentes paulistas.

${ }^{341}$ Correio Paulistano, em 28 de maio de 1938, p. 8. 
Ao criar um clima tenso entre os clubes e entidades de futebol dos dois maiores estados do país, a elite paulista fomentava a rivalidade regional na massa torcedora sentimento nocivo ao projeto nacional estadonovista. Assim, barganhava-se um lugar político de destaque no futebol brasileiro em troca da pacificação da massa e divulgação da ideologia oficial:

“O ambiente esportivo nacional está agitado, em virtude do gesto do Vasco da Gama, do Rio, procurando sempre ferir os brios e interesses dos paulistas. Se já não bastassem os grandes aborrecimentos causados, ainda agora, o grêmio cruzmaltino resolve vingar-se na figura de um representante de São Paulo na Capital Federal. A tensão é tão grande que a Liga de Futebol de São Paulo resolveu cortar as relações de amizade com o Vasco da Gama” ${ }^{342}$.

Graças a gestos tidos como hostis ao brio bandeirante e às declarações consideradas pelos jornais paulistas como infelizes realizadas por dirigentes do Vasco da Gama em dezembro de 1938, a crônica esportiva fomentou o clima de tensão instaurado entre a Liga de Futebol do Estado de São Paulo e o clube carioca, inclusive concordando com a decisão da entidade paulista em cortar relações com o último ${ }^{343}$.

\footnotetext{
${ }^{342}$ Correio Paulistano, 25 de dezembro de 1938, p. 14.

${ }^{343}$ De acordo com Mazzoni, a briga entre a Liga Paulista de Futebol e o Vasco da Gama foi provocada pela transferência do jogador Jaú para o clube cruzmaltino. Como forma de punir o clube carioca, a Liga Paulista prometeu não jogar o Campeonato Brasileiro de 1938, em São Januário - ideia que não foi levada às vias de fato. MAZZONI, Thomas (Olimpicus). Op. cit., p. 282.
} 


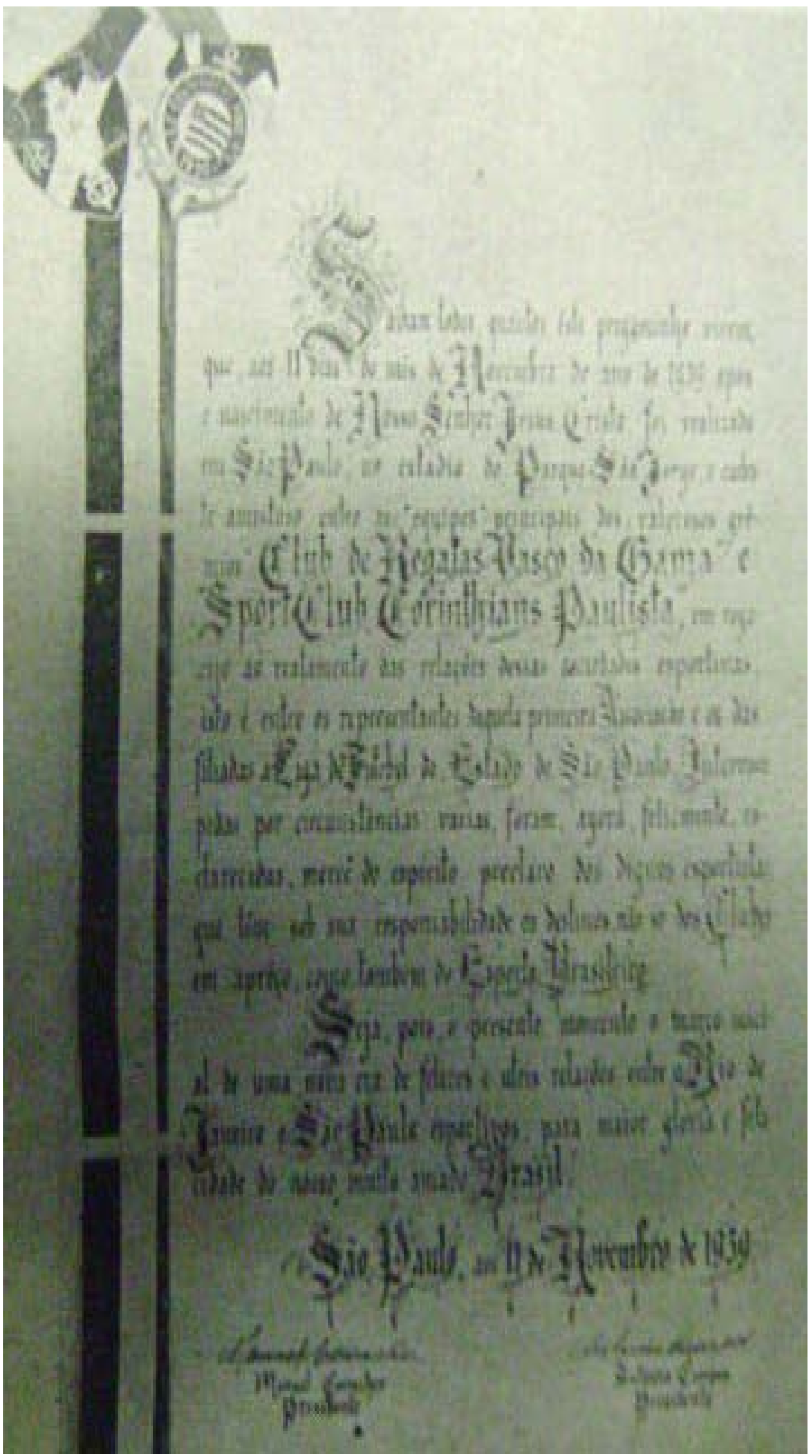

Ata assinada pela diretoria do Vasco e do Corinthians confirmando que as relações entre os dois clubes foram reatadas. Gazeta Esportiva, 27 de novembro de 1939, p. 3. 
Para firmar São Paulo como o grande centro futebolístico do país, a elite desse estado realizou fortes campanhas para ver seus jogadores na seleção brasileira, com o intuito de propagandear a grandeza do estado no exterior:

\begin{abstract}
"Tem causado profunda impressão em nossos círculos esportivos a campanha surda que certos organs da imprensa carioca vêm movendo contra os jogadores de São Paulo requisitados para a formação do seleccionado nacional. Esses rapazes tem sido hostilizados de toda forma, chegando-se ao cúmulo de serem apontados como responsáveis pelo desastre de domingo último [Argentina 5 x 1 Brasil, pela Taça Roca, $1^{\circ}$ jogo], sem se lembrarem que a base da nossa seleção foi o famoso conjunto Fla-Flu” ${ }^{344}$.
\end{abstract}

Na notícia acima, são notáveis o latente regionalismo estadual e a percepção da imprensa esportiva como um meio para fomentar paixões. A imprensa e o público carioca eram considerados pelo jornalista como elementos violentos e hostis aos jogadores paulistas.

Os clubes, assim como as entidades reguladoras do futebol carioca, eram taxados como mesquinhos pelos paulistas, e jogar na capital do país foi, algumas vezes, tido como inseguro, pois os guanabarinos, em certas ocasiões, não se comportavam civilizadamente.

Nesse contexto, no qual exaltar as qualidades do futebol paulista significava enaltecer o estado e a sua elite dirigente criando a ideia de ser essa última a classe ideal para comandar a nação, a grande presença do público nos estádios durante o campeonato paulista e a própria construção do Pacaembu foram fatores destacados pelos jornais esportivos durante o Estado Novo.

Vencer o campeonato nacional de futebol era de extrema importância para projetar São Paulo e sua classe dirigente para os demais territórios nacionais. Assim, o fato de a última partida da série dos jogos finais ser, quase sempre, disputada no Rio de Janeiro, era um fato duramente criticado pela crônica esportiva bandeirante:

\footnotetext{
${ }^{344}$ Correio Paulistano, 21 de janeiro de 1939, p. 9.
} 
“É interessante notar que, quando se recorre ao sorteio para escolha do campo para o terceiro encontro entre paulistas e cariocas, a sorte sempre protege... os cariocas. Até parece uma preferência clássica. Mas certa vez, em 1934, houve alguém que leu, depois, os papeluchos usados e não encontrou entre elles o nome de S. Paulo...” 345.

Os jornalistas paulistas argumentavam ser melhor a realização da última partida da final no Pacaembu, pois arrecadaria maior receita. Porém, como o local para a realização do jogo era decidido por sorteio, as matérias traziam a suspeita desse não ser realizado honestamente.

A final do Campeonato Brasileiro de 1940, disputada em janeiro de 1941, igualmente apresentou manifestações regionalistas fruto da rivalidade políticoeconômica e futebolística entre os estados de São Paulo e Rio de Janeiro.

O primeiro jogo, disputado no Pacaembu, teve vitória paulista por três gols a um e foi noticiada pela Gazeta de Notícias da seguinte forma:

"O sr. Pessoa [o árbitro] transformou o prélio, no segundo meio tempo, em um verdadeiro Carnaval, no qual revelou ser o verdadeiro Boneco da noitada sportiva. Os bandeiras que eram quatro árbitros paulistas, dirigiam o jogo como convinha a representação bandeirante, não ligando a mínima importância ao homem em má hora lembrado pela Federação Brasileira de Football para desempenhar o papel de dirigente em um jogo que exigia um juiz enérgico e imparcial (...) A parcialidade dos que dirigiram o cotejo foi tamanha, que até o próprio honometrista não descontou os 15 minutos em que o jogo esteve interrompido pelas scenas desagradáveis verificadas entre os 'players' em campo [Alcebíades agrediu Servílio e lutou com Luizinho]. Perdemos e até ahi nada vemos de anormal. Os paulistas são sempre os eternos rivaes dos cariocas, porém, desta feita, lutamos contra tudo, inclusive mesmo as próprias autoridades policiaes, que não nos deram as garantias necessárias. Resultado: - A turma chegou e, contando uma porção de coisas, que depõem, sem duvida, contra o football paulista. A Liga de Football do Rio de Janeiro, em gesto natural de defesa, vae recorrer, frizando um erro de direito, pois faltavam ainda 15 minutos para terminar o primeiro prélio, embora o sr. Castello Branco presidente da Federação Brasileira de Football, julgue que isso não se deva fazer [o ato de discutir o futebol brasileiro]. Pensamos o contrário: A Liga de Football deve pleitear essa medida como um ato moralizador...” ${ }^{346}$.

O sentimento regionalista estava expresso desde a primeira frase da matéria ao

destacar a falta de qualidade e imparcialidade dos auxiliares paulistas até a última, pois

o jornalista carioca colocou apenas a Liga de Futebol de seu estado como digna para realizar uma purificação no futebol nacional.

Além de destacar a rivalidade latente entre cariocas e paulistas, o jornalista

\footnotetext{
${ }^{345}$ Correio Paulistano, 14 de fevereiro de 1939, p. 8.

${ }^{346}$ Gazeta de Notícias, 14 de janeiro de 1941, p. 10.
} 
estranhou a atitude policial em não interferir para manter a ordem dentro de campo. Em uma sociedade autoritária, onde a disciplina e a harmonia deveriam moldar o corpus social, a não interferência do aparato coercitivo do Estado causava a indignação no jornalista - cidadão.

Outro elemento separatista presente na reportagem estava na possibilidade dae a Liga de Futebol do Rio de Janeiro ir contra os princípios de unidade defendidos pelo governo e postos em prática pela Federação Brasileira de Futebol. Apesar de não ter levado a reclamação a diante, o simples fato de ter cogitado em fazê-la constitui-se sintomático, pois o futebol carioca raramente fazia esse tipo de ameaça (mais comum no futebol paulista).

Ao escrever sobre o segundo jogo final, disputado nas Laranjeiras, a Gazeta Esportiva realizou o seguinte comentário sobre a primeira partida:

\begin{abstract}
"Em primeiro lugar: como sempre houve jornais da Capital da República que honrando a sua tradição, tudo deturparam a respeito da peleja de sábado passado [o primeiro jogo], no Pacaembu, apresentando-nos como verdadeiros selvagens. A dar créditos as suas versões, tanto os jogadores quanto o público bandeirante teriam maltratado bemquistos [sic] visitantes; aqueles usando de inominável violência, e este apupando-se de modo incrível, atirando-lhe toda sorte de projeteis (...) Em conseqüência, os bandeirantes somente poderiam esperar o pior possível e, assim, pagar o mal que não fizera. E foi justamente o que se deu. Desde que o camboio entrou nos mais longínquos subúrbios, a embaixada começou a ser alvo de manifestações de patente desagrado, fosse por gestos; fosse por palavras. O mesmo aconteceu quando pisamos a estação de Alfredo Maio, o mesmo sucedeu durante o tempo que esperávamos o momento de rumarmos ao campo do Fluminense. Até pelo telefone houve ameaças dirigidas aos jogadores de São Paulo (Del Nero, diplomata que é, chegou a convencer muitos anônimos de que, tudo quanto dizia não passava de invencionice, o que, aliás, é verdade). A culpa a quem cabe? A essa imprensa que não mede conseqüências de suas afirmativas uma vez que se trate de atingir maior tiragem e, ao mesmo tempo, acirrar os ânimos para que, mais e mais, se distanciam e haja estremecimento entre os dois maiores centros esportivos do pais. Lamentável, bem lamentável” ${ }^{347}$.

O jornalista paulista iniciou a matéria negando as acusações realizadas pela
\end{abstract}

imprensa carioca sobre as irregularidades na primeira partida que, supostamente, teriam

beneficiado a seleção bandeirante.

Ao analisar a reportagem é possível compreender como era grande o poder

${ }^{347}$ Gazeta Esportiva, 18 de janeiro de 1941, p. 10. 
mobilizador da imprensa esportiva. Graças às matérias criticando a atuação dos paulistas no primeiro jogo divulgadas na imprensa carioca dias antes, sentimentos calcados na rivalidade regional foram dispertados na massa torcedora e provocaram inúmeras situações desagradáveis quando os paulistas foram ao Rio de Janeiro para o segundo jogo final.

O caráter mercantil da imprensa esportiva, voltada para os setores populares da sociedade, calcada nas notícias sensacionalistas e nas intrigas esportivas era outro elemento presente na notícia. A paixão futebolística e a identidade regional do torcedor escapavam dos censores, aumentavam os lucros da imprensa e minavam os valores básicos do regime.

Esse fato demonstrou como os agentes sociais, por mais controlados que fossem, sempre burlam os sistemas autoritários com suas práticas sociais. O sentimento regionalista presente nos jornalistas e torcedores eram inflamados pelos primeiros, apesar de contrariarem os ideias autoritários do regime, pois esses também eram torcedores de seus estados e selecionados estaduais.

Outro momento crítico para os interesses do Estado Novo em que a rivalidade regional entre os estados de São Paulo e do Rio de Janeiro transpareceu intensamente na constituição do selecionado nacional, foi durante a Copa Roca de 1940.

A escolha do local e do técnico para tal competição foi realizada para agradar os paulistas fazendo-os sentir mais participantes do escalão dirigente do esporte nacional. Desse modo, escolheu-se a cidade de São Paulo para sediar a competição e o paulista Sylvio Lagreca para comandar o selecionado nacional.

Porém, os periódicos cariocas desde o início da preparação realizavam críticas sobre o trabalho do técnico paulista e reivindicavam a presença dos jogadores cariocas no time titular: 
"Há quem estranhe o facto de ter Lagreca escalado Junqueira em logar de Florindo e Del Nero em logar de Argemiro, Não cabe, porém, o gesto de espanto. É preciso acentuar, antes de tudo, a condição de Lagreca - um technico paulista, não um technico carioca. Isso significa, em primeiro lugar, que Lagreca não tem, em relação ao foot-ball carioca, um cohecimento profundo (...) A torcida carioca, por exemplo, conhece o foot-ball paulista por informação. Pode-se dizer o mesmo sobre a torcida paulista, salientando-se, naturalmente, que os factos parecem provar - pela coincidência das victórias obtidas pelos cariocas contra os paulistas - a superioridade do 'soccer' guanabarino. Não se trata, agora, de estabelecer comparações e sim de salientar a impossibilidade de Lagreca evitar erros iniciaes. O receio não está na escalação para um treino, de Junqueira e Del Nero e sim em uma escalação definitiva (...) O seleccionador único terá que esquecer em primeiro logar, que é um paulista para não distinguir, entre os vinte e cinco 'cracks' cariocas e paulistas. A dezoito de fevereiro não estará em jogo, absolutamente, de forma alguma, a vaidade do foot-ball paulista ou a vaidade do foot-ball carioca mas, apenas, de modo claro e iniliudivel, o prestígio do foot-ball brasileiro - bastante acima de regionalismos estreitos" ${ }^{348}$.

O jornalista carioca não aprovava Lagreca no comando da seleção brasileira e acusava-o de bairrista por não escalar jogadores cariocas mesmo sendo esses, em sua opinião, muito melhores que os paulistas de suas posições.

Além disso, Mário Filho criticou a falta de conhecimento técnico de Lagreca para ocupar o importante cargo no selecionado, pois sequer conhecia os jogadores do melhor futebol praticado no país, o carioca.

Apesar do teor regionalista de sua reportagem, o jornalista encerrou o texto em afinidade aos valores do regime, destacando a importância de se praticar um futebol unido e bem jogado para honrar e elevar a imagem da nação para a massa torcedora.

Devido às fortes pressões exercidas pela imprensa carioca e às críticas provenientes de dirigentes do mesmo estado, Lagreca renunciou ao cargo antes do final da competição. O técnico carioca Jayme Barcellos foi escalado para substitui-lo.

A imprensa carioca noticiou com maior intensidade se comparada à imprensa paulista a demissão de Lagreca. Apesar da Liga de Futebol do Estado de São Paulo ter se solidarizado com o técnico paulista, a única nota divulgada nos jornais paulistas analisados após a despedida de Lagreca foi publicada no Correio Paulistano:

“O que preoccupa sobremaneira os esportistas é a repercussão dessa desintelligencia no seio do

\footnotetext{
${ }^{348}$ Jornal dos Sports, 27 de janeiro de 1940, p. 2.
} 
esporte nacional, dado o papel preponderante de São Paulo e a confirmação da existência de um bloco político de hostilidade à gente esportiva bandeirante” ${ }^{349}$.

As constantes notícias cariocas sobre o caso podem, talvez, sererm explicadas pelas inúmeras críticas realizadas pelos jornais locais durante a preparação do selecionado. A imprensa do Rio de Janeiro pode ter se sentido na obrigação de divulgar as causas da demissão do técnico paulista após tantas insinuações sobre a sua falta de competência para o cargo.

Na única notícia paulista sobre o caso, o poderio futebolístico do estado foi destacado e o regionalismo exaltado pela declaração de existir um grupo político contrário aos interesses e aos valores esportistas defendidos por São Paulo.

As notícias acima reproduzidas demonstram como as rivalidades regionais se apresentavam no futebol de modo latente, destacando como estava ainda por concretizar o projeto nacional proposto pelo Estado Novo. Além da opinião pública do país, estava em jogo a formação da própria nação e a divulgação da sua imagem no exterior.

${ }^{349}$ Correio Paulistano, 23 de fevereiro de 1940, p. 8. 


\title{
4.3 O Jogo das Elites
}

Nesse jogo de rivalidades regionais, como o futebol foi utilizado pela elite paulista para voltar a ocupar um lugar de destaque no cenário político nacional perdido com o início do governo varguista e competir com a capital do país para regê-lo?

Para se responder a essa pergunta, será analisada a formação do mito bandeirante para se compreender como São Paulo, pela construção de um discurso pautado pela diferenciação e exepcionalidade do povo paulista, conseguiu alavancar um lugar de destaque na esfera dirigente da nação.

Com a instauração do governo republicano, uma questão colocou-se como fundamental: era necessário aliar a ideia do federalismo político com a de unidade nacional. Nesse sentido, as bandeiras rumo ao sertão contribuiriam para integrar as regiões brasileiras, definir e defender as fronteiras nacionais.

Para Capistrano de Abreu, um dos responsáveis pela construção do mito bandeirante, os caminhos abertos pelos paulistas no interior do país foram fundamentais para proporcionar comunicação entre as diferentes regiões brasileiras, unificando-as de fato. Sobre o processo de engradecimento das bandeiras, Danilo Ferretti escreveu:

\begin{abstract}
"Entendida sob um ponto de vista territorialista, a figura do bandeirante se transformava em um dos pontos centrais de um imaginário de modernidade social. De símbolo maior dos vícios originais da nacionalidade, como a entendia a historiografia indianista, a Bandeira passava, paulatinamente, a representar um evento central na constituição da nação brasileira, na medida em que, além de ocupar o interior, 'costurava' os dispersos núcleos de povoamento, possibilitando a integração e constituição de uma unidade do território nacional, objetivo almejado pelas elites modernizadoras de finais do século XIX” ${ }^{350}$.
\end{abstract}

A excepcionalidade paulista conferia a São Paulo uma diferenciação necessária para ser o estado líder da nação brasileira. Desse modo, a elite republicana e liberal

\footnotetext{
${ }^{350}$ FERRETTI, Danilo José Zioni. Op. cit., p. 141.
} 
paulista $^{351}$ construiu uma identidade regional marcada por esse sentimento de exceção.

Apesar de a base discursiva ser a autonomia estadual, esse discurso identitário processou-se de dois modos distintos: de um lado estava a concepção do regional como preponderante sobre o todo nacional; do outro, São Paulo era considerado como uma realidade irreconciliável com o Brasil ${ }^{352}$.

A ideologia dos liberais paulistas era modelada de acordo com os princípios liberais e republicanos dos norte-americanos. Ambas continham as seguintes ideias: colonização do sertão realizada por imigrantes, forte política ferroviária, desenvolvimento industrial e um original espírito de iniciativa e independência frente ao Estado $^{353}$.

Com a ascenção de Washington Luis candidato do Partido Republicano Paulista, divulgou-se, política e culturalmente, o destino manifesto de São Paulo ser o estado escolhido para reger o país, conforme pensado pela sua elite liberal ${ }^{354}$.

\footnotetext{
${ }^{351}$ Na época monárquica, o poderio econômico proveniente do café possiblitou o surgimento de um grupo republicano na província paulista, contestador da centralização política no período. A principal reivindicação desse grupo era diminuir os impostos nas exportações do café, praticados pela monarquia. Idem. Ibidem. p. 145.

${ }^{352}$ Idem. Ibidem. p. 150.

${ }^{353}$ Idem. Ibidem. p. 158.

${ }^{354}$ Nesse contexto foram destaques a construção do IHGSP e as comemorações do Centenário da Independência em um movimento de rememoração do passado nacional, de modo a engrandecer São Paulo. Idem. Ibidem. p. 329.
} 


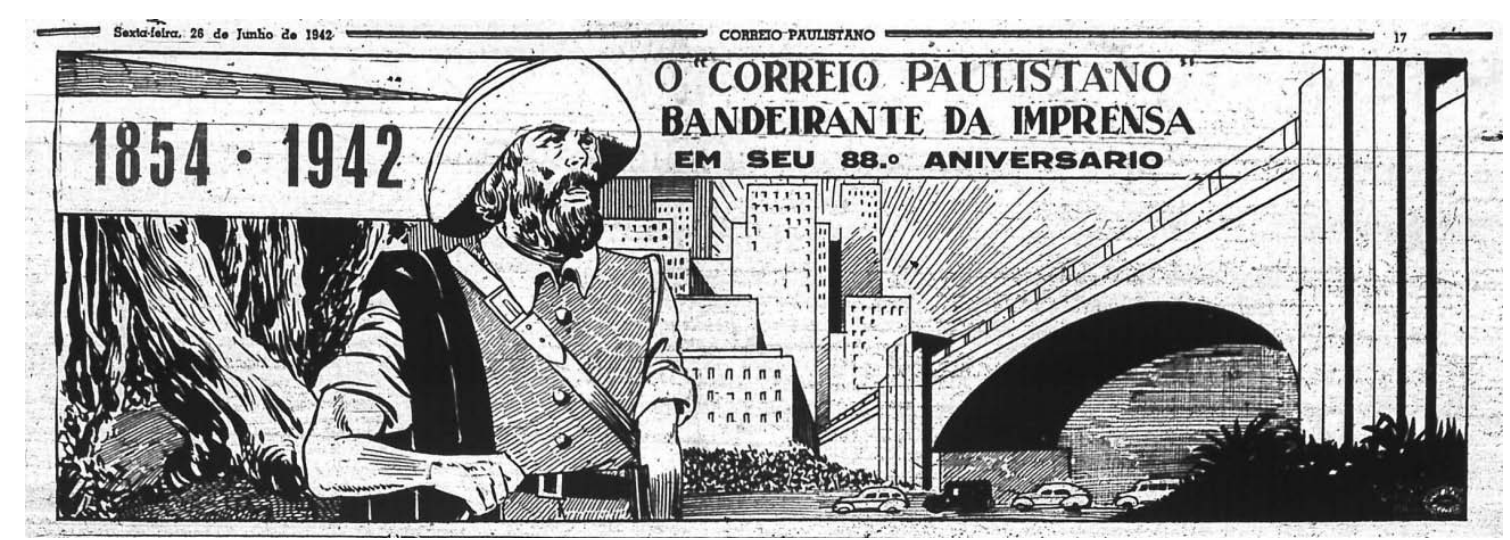

Desenho divulgado no Correio Paulistano, jornal oficial do Partido Republicano Paulista, no período anterior ao Estado Novo, no qual a elite liberal paulista foi apresentada como um bandeirante que intermedia o passado colonial e a modernidade da presente nação. Correio Paulistano, 26 de junho de 1943, p. 17.

Porém, a estabilidade da elite paulista sofreu um forte revés com a implantação do Governo Provisório realizada por Getúlio Vargas, em 1932. Nessa nova conjuntura política, visando a controlar a recessão econômica provocada pela crise do capitalismo mundial (resultado das drásticas quedas das bolsas de valores americanas em 1929) a cultura cafeeira, principal atividade econômica de São Paulo, sofreu um forte controle governamental.

Além disso, interventores militares foram nomeados por Vagas para governar os estados da federação em uma tentativa de desestruturar as bases políticas das oligarquias regionais tradicionais.

Na tentativa de inverter o cenário político e voltar aos lugares de comando nos rumos nacionais partidos políticos paulistas, outrora oponentes, se uniram como no caso do Partido Democrático que se reagrupou com o Partido Republicano Paulista originando a Frente Única Paulista (FUP). A FUP defendia a constitucionalização do Estado e recebeu o apoio de diversas entidades representativas de profissionais liberais como advogados, médicos e engenheiros ${ }^{355}$.

O mito bandeirante foi reconstruído durante esse período de luta entre as elites

${ }^{355}$ RAIMUNDO, Silvia Lopes. Op. cit., p. 92. 
paulistas e governo central. Durante o movimento armado de 1932 engendrado pelos liberais paulistas para retomarem o seu poderio político, o bandeirante foi associado ao soldado que lutava por amor a São Paulo.

Sobre a relação entre esses dois símbolos, Silvia Raimundo escreveu ${ }^{356}$ :

"Nesse momento o principal personagem das antigas bandeiras paulistas reapareceu animado pelo sentido de unir a população de São Paulo à causa da constitucionalização. A partir de então o bandeirante e o soldado constitucionalista passaram a ser identificados como um só símbolo do ímpeto paulista na luta pela autonomia política do estado”.

Todos aqueles que contribuissem de alguma forma para a implantação do projeto econômico e político das elites paulistas defendidos nos combates de 1932, eram considerados pela propaganda vinculada em todos os meios de comunicação de massa como verdadeiros heróis bandeirantes.

Não precisava ser descendente dos povoadores de São Paulo, dos quatrocentões paulistas, para ter sua imagem associada aos bandeirantes em 1932. Como o único pré-requisito era estar imbuído do espírito de luta, na propaganda de guerra, os imigrantes, negros e índios foram colocados juntamente com membros da elite como herdeiros de algo especial, provenientes dos sertanistas e que deveriam ser defendidos ${ }^{357}$.

Esse movimento armado para resgatar a soberania paulista envolveu o universo futebolístico. Para arrecadar fundos para a luta paulista foi coordenada uma campanha para doação de ouro, para a qual inúmeros clubes contribuiram, em especial o Santos F C que chegou a propor a doação de todos os seus troféus em prol da causa - o que não foi necessário, pois alguns dirigentes organizaram uma coleta para levantar fundos e salvar o patrimônio santista ${ }^{358}$.

\footnotetext{
${ }^{356}$ Idem. Ibidem. p. 95.

${ }^{357}$ Idem. Ibidem. pp. 97-99.

${ }^{358}$ AGOSTINO, Gilberto. Op. cit., p. 141.
} 
Muitos jogadores ajudaram a causa paulista, com destaque para Friedenreich, que doou seus troféus e medalhas obtidos nas vitórias futebolísticas. El Tigre alistou-se no Batalhão dos Esportistas, lutou nas trincheiras de Eleutério e conquistou o posto de sargento. Ao final do movimento, o jogador foi elevado a tenente e voltou a jogar futebol $^{359}$.

Foi durante esses turbulentos anos iniciais da década de 30 do século XX, cheios de agitações políticas e econômicas, que o futebol brasileiro encerrou o seu processo de profissionalização nas duas principais cidades do país, a saber: São Paulo e Rio de Janeiro ${ }^{360}$.

O primeiro passo rumo à profissionalização do futebol foi dado pelo clube carioca Vasco da Gama quando esse ganhou um campeonato regional, em 1923, colocando negros e brancos pobres e analfabetos para jogar. Os grandes clubes cariocas, como protesto, fundaram a AMEA e não convidaram o Vasco para se associar.

Porém, o futebol foi se popularizando tanto nas arquibancadas como dentro de campo, pois os dirigentes compreenderam que para ganhar campeonatos e atrair o público, ou seja, gerar receita, era necessário colocar os bons jogadores para atuar - não importando a sua origem social.

Nesse profissionalismo velado denominado “amadorismo marrom”, os jogadores provenientes dos setores sociais mais humildes ganhavam prêmios por suas atuações (conhecidos como "bichos”) ou eram contratados por alguma fábrica ligada ao

\footnotetext{
${ }^{359}$ Idem. Ibidem. pp. 141-142.

${ }^{360}$ Há diferentes divisões sobre a história do futebol brasileiro como a realizada por Levine: a primeira (1864-1904) se caracterizaria pela restrição do esporte nos clubes urbanos pertencentes a estrangeiros; a segunda (1905-1933) seria a fase amadora, com forte divulgação e pressão para melhorar o jogo através de subsídios aos jogadores; na terceira (1933-1950) iniciou-se o profissionalismo e a fase pós 1950 ficaria marcada pelo reconhecimento internacional acompanhado de maturidade e uma comercialização sofisticada. MEIHY, José Carlos Sebe Bom e WITTER, José Sebastião (Orgs.). Futebol e Cultura Coletânea de estudos. Convênio IMESP/DAESP. Imprensa Oficial: Arquivo de Estado. São Paulo, 1982. p. 23.
} 
clube para receber um salário por esse emprego.

Aos poucos o processo de profissionalização foi angariando defensores em São Paulo e no Rio de Janeiro como intelectuais, jornalistas, jogadores de futebol e alguns dirigentes de clubes. As entidades reguladoras de futebol foram percebendo que a profissionalização iria estruturar melhor o futebol, proporcionando maiores rendas e conseguiria manter os jogadores atuando no país (na fase amadora, vários jogadores foram atuar no futebol profissional do exterior que pagava salários por suas atuações).

A rivalidade futebolística entre os dois principais estados da federação constituiu, desde o início, o processo de profissionalização desse esporte no país, destacando o modo como a sua regulamentação precoce em relação aos demais territórios nacionais foi um fator determinante para a prática do jogo com excelência.

De acordo com Bourdieu, no campo das práticas esportivas ocorrem lutas para disputar, entre outras coisas, o monopólio sobre a imposição da legítima definição sobre prática esportiva e a função desse tipo de atividade ${ }^{361}$.

Além desse embate, esse campo pode apresentar outros, como aquele existente entre a prática esportiva amadora e a prática profissional, o esporte voltado à competição e aquele ligado ao espetáculo, o esporte elitista e o popular e as lutas pela definição do corpo legítimo e do uso legítimo do corpo.

Desse modo, o campo de disputas esportivas entre clubes e selecionados de São Paulo e do Rio de Janeiro se misturavam com os conflitos latentes no campo político, expressos com maior vigor na luta armada de $1932^{362}$.

Um exemplo deste imbricamento consiste na charge desenhada por Moles e divulgada no Correio Paulistano sobre o Campeonato Sulamericano de 1945, disputado no Chile:

\footnotetext{
${ }^{361}$ BOURDIEU, Pierre. Op. cit., p. 142.

${ }^{362}$ Exemplificando essa rivalidade regional dentro de campo, o Torneio Rio - São Paulo foi criado em 1933 para demonstrar os benefícios da profissionalização do futebol. CALDAS, Waldenyr. Op. cit., pp. 388-389.
} 


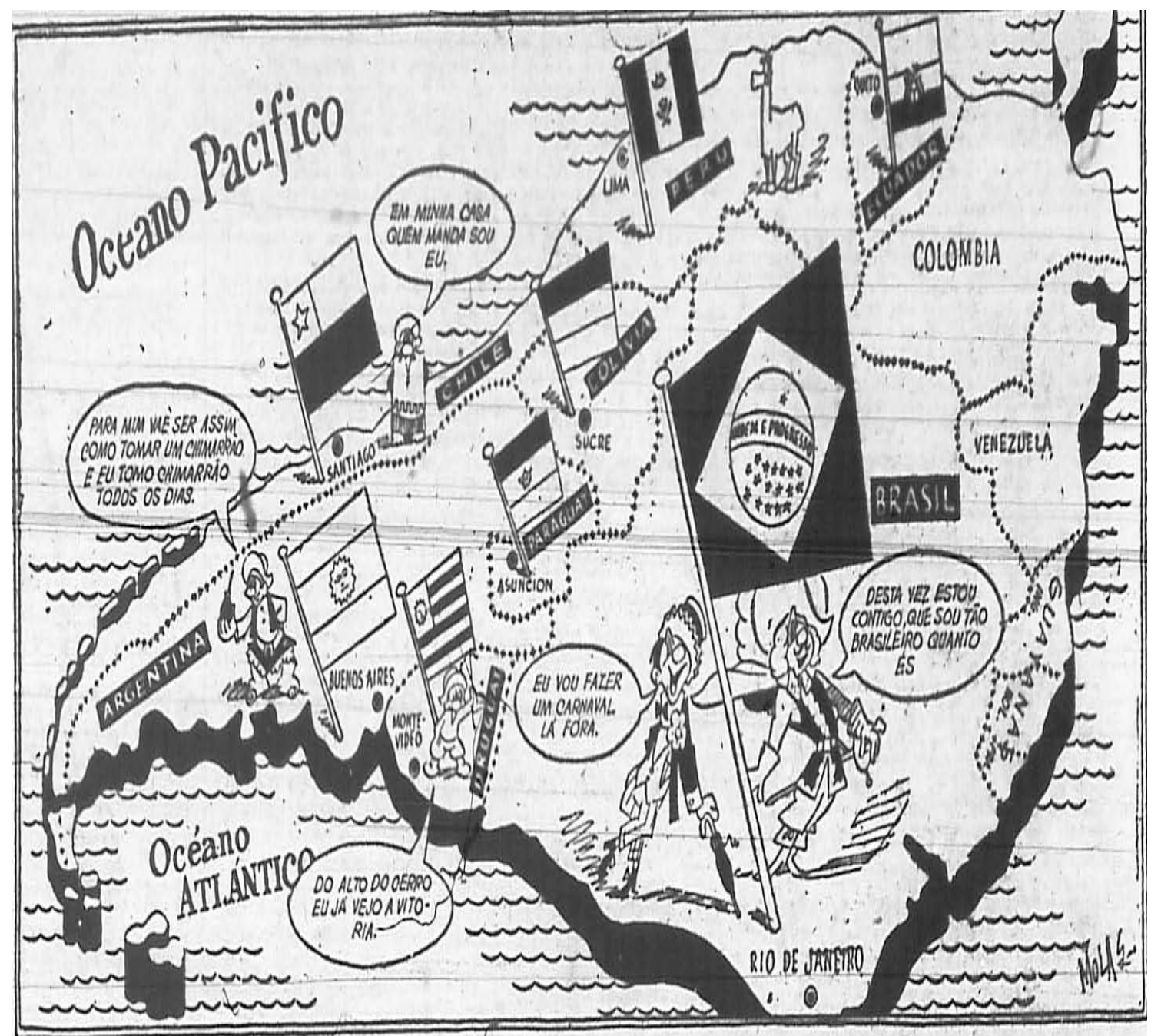

O Compoorato Sul-Amoricomo do Pulbbol visto por Moles

Desenho sobre o Campeonato Sulamericano de Futebol de 1945, disputado no Chile. Correio Paulistano, 08 de fevereiro de 1945, p. 10.

No desenho nota-se uma diferenciação representativa entre os jogadores do selecionado brasileiro. Enquanto os cariocas foram caracterizados como malandros, ligados à farra e ao carnaval, os paulistas foram desenhados como bandeirantes, herdeiros do poder, da tradição e excepcionalidade de São Paulo.

A rivalidade entre esses dois estados foi demonstrada de forma latente na charge, pois apesar de a bandeira nacional estar presente entre os dois personagens, a fala do bandeirante paulista destacou como aquele momento em que ele estava unido aos mesmos objetivos do personagem carioca era uma raridade. 
Mais uma vez o tradicional jornal paulista, antigo órgão do PRP, trouxe os paulistas representados como bandeirantes. Porém, a pecularidade dessa imagem consiste em demonstrar jogadores de futebol e não membros da elite, como herdeiros das bandeiras.

Para os liberais paulitas, utilizar o futebol para realizar o enfrentamento ao centro do governo e tentar retomar o seu posto na esfera decisória da política nacional, consistia em aproveitar o mesmo elemento cultural que o governo usava para concretizar os seus projetos.

Nesse contexto de rivalidades, em 1935, constitui-se o São Paulo Futebol Clube cujo nome representava o enfrentamento desse estado frente ao poder simbolizado pelo estado do Rio de Janeiro. O sentimento regionalista na formação do clube foi assunto na matéria publicada Correio Paulistano ${ }^{363}$ :

"Já por várias vezes temos acentuado que o São Paulo F C não é somente um clube da cidade. É um grêmio genuinamente brasileiro e que precisa, por isso mesmo, do amparo de todos esportistas que desejam o equilíbrio do nosso futebol”.

Na tentativa de angariar ajuda para a formação do clube, o jornalista ressaltou as características nacionais do tricolor paulista tentando diminuir o sentimento regional presente na sua formação. Para legitimar o caráter nacional do clube, o autor do texto destacou a prática futebolística do São Paulo existente desde o seu nascimento.

A história da fundação desse clube merece ser estuda com mais profundidade, pois o seu departamento de futebol constituído graças às doações provenientes das classes mais populares da cidade rememorava a tradição paulista de reger politicamente a nação e realizava o enfrentamento referente à perda desse mesmo status.

Sua origem humilde foi ressaltada por Mazzoni quando esse escreveu sobre a

\footnotetext{
${ }^{363}$ Correio Paulistano, 4 de maio de 1940, p.8.
} 
história do futebol brasileiro:

“Estava novamente de pé o S Paulo F C [sic], mas pobre, 'pequeno’ clube apenas. Obstáculos tremendo começaram a surgir. Vivia o clube de fé... Foi porisso [sic] que começou a ser chamado de "clube de fé" 364 .

A maioria dos palestrinos entrevistados por Alfredo Salun ressaltaram a falta de patrimônio do clube tricolor ao afirmarem que esse clube tentou invadir e roubar a sede do Palestra Itália quando esse sofreu hostilidades por representar "súditos do eixo" em $1942^{365}$. Sobre a falta de recursos do São Paulo o chefe da torcida palestrina, Agostinho Záccaro, afirmou que o tricolor paulista “não tinha onde cair morto” 366.

Nesse processo de afirmação nacional, a transferência de Leônidas da Silva para o São Paulo constitui um momento fundamental. O jogador mestiço, representante das classes populares, adorado pela massa e que fundamentou a construção discursiva de um modo genuinamente brasileiro de jogar futebol (cheio de arte, ginga e descompromisso tático) trouxe para o recém criado clube paulista uma gama imensa de torcedores pertencentes às classes populares que se identificavam com o jogador.

Assim, o clube tricolor era também denominado como “o mais querido” clube de São Paulo. A oralidade apregoa duas diferentes histórias sobre a origem do termo. Uma delas elucida a ligação desse clube com o destino político de São Paulo, pois denominar tal clube como "o mais querido” foi a maneira encontrada por Vargas para tentar diminuir as tensões decorrentes da derrota paulista na Revolução Constitucionalista na ocasião de um desfile de associações assistido em São Paulo quando a população ovacionou simbolicamente esse clube como forma de enaltecer o

\footnotetext{
${ }^{364}$ MAZZONI, Thomas (Olimpicus). Op. cit., p. 262.

${ }^{365}$ SALUN, Alfredo Oscar. Op. cit., p. 157, 160, 163, 175 e 180.

${ }^{366}$ Idem. Ibidem. p. 165. Apesar do conteúdo dessas entrevistas destacar a característica humilde do recém criado São Paulo Futebol Clube, Salun demarcou tal clube como elitista desde a sua fundação. SALUN, Alfredo Oscar. Op. cit., p. 53.
} 
estado paulista ${ }^{367}$.

A outra versão da história encontra-se documentada nas páginas da Gazeta

Esportiva, quando essa realizou um concurso para descobrir qual era o time mais querido de São Paulo. O direito de votar era conquistado após a pessoa comprar uma garrafa de vinho da empresa que estava patrocinando o concurso.

Nas edições do jornal, encontra-se a primeira prévia da apuração dos votos quando o São Paulo Futebol Clube estava na segunda colocação perdendo apenas para a Portuguesa de Esportes ${ }^{368}$.

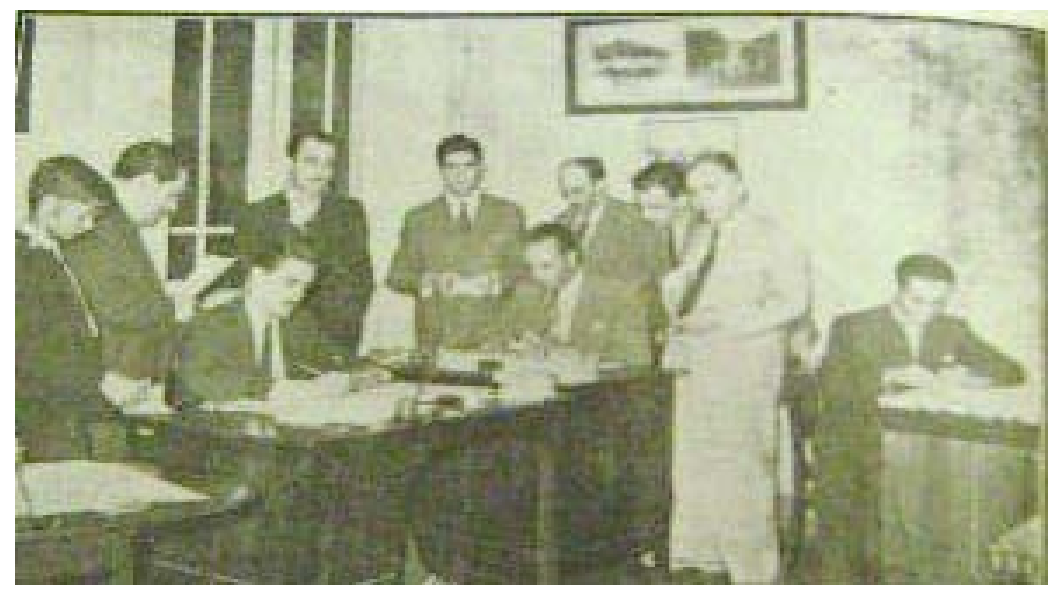

Foto da primeira apuração do concurso para eleger o clube "mais querido" de São Paulo. Gazeta Esportiva, 23 de setembro de 1940, p. 3.

\footnotetext{
${ }^{367}$ Durante a pesquisa, encontrou-se uma notícia que se assemelha a essa história. O jornalista escreveu que, durante a inauguração do Pacaembu, as delegações recebidas pelo público com mais entusiasmo, durante o desfile foram o Palestra, Syrio e Corinthians. Porém, nenhuma delas foi acolhida pelos espectadores com mais palmas e alegria que o clube detentor do nome da cidade, o São Paulo Futebol Clube. Correio Paulistano, 28 de abril de 1940, p.2.

${ }^{368}$ A edição de 07 de setembro de 1940, terceira página da Gazeta Esportiva, trouxe detalhes sobre o concurso patrocinado pela Quinta do Monteiro, no qual votaria apenas quem comprasse o vinho português "Quinta do Monteiro" ou o brasileiro "Furão". Além disso, na mesma notícia, foram divulgados os times participantes da competição, a saber: Palestra, Corinthians, Portuguesa de Esportes, São Paulo, Ipiranga, SPR, Tietê - Esperia, Portuguesa Santista, Santos, Espanha, C R Vasco da Gama de Santos, C R Saldanha da Gama de Santos, Ponte Preta, Guarane e C R Campineiro. O resultado da primeira apuração encontra-se na Gazeta Esportiva de 23 de setembro de 1940, p 3.
} 
A segunda versão sobre o epíteto elucida a presença dos periódicos esportivos na massa torcedora, além da força mobilizadora do futebol junto aos setores mais populares da sociedade. Além disso, por essa história percebe-se a estreita relação formalizada entre a imprensa e seus leitores.

Após a afirmação desse clube no futebol nacional, a saga de seus dirigentes para conseguir construir um estádio próprio pode ser associada à luta da elite paulista para conseguir um novo lugar na política nacional.

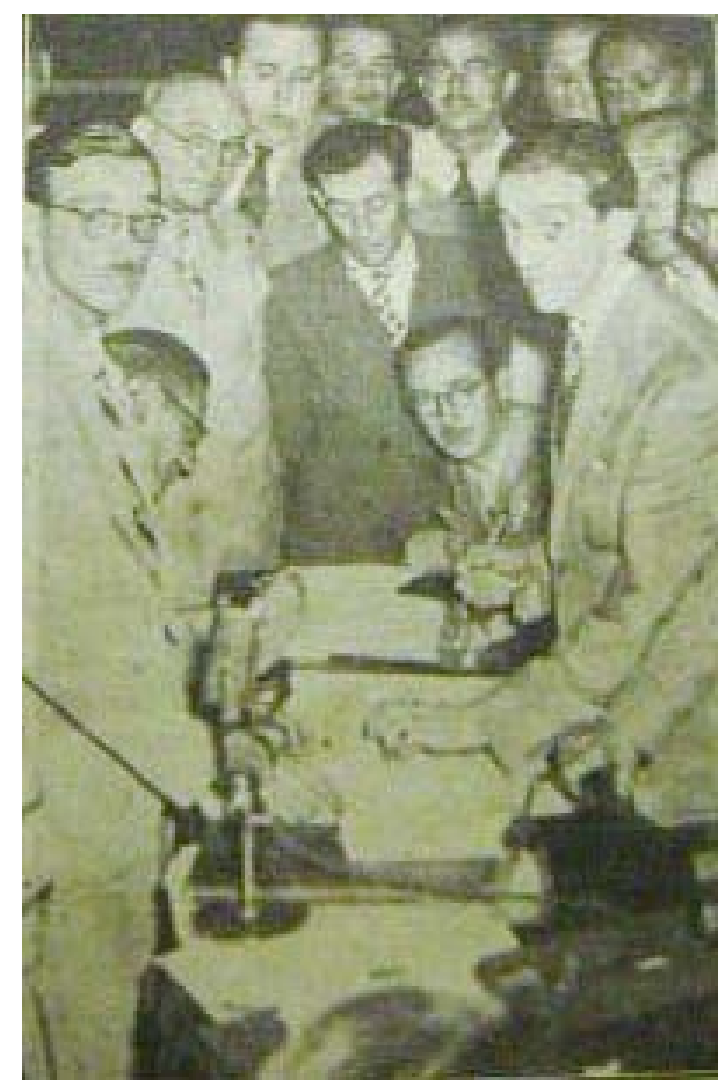

Foto da diretoria do São Paulo Futebol Clube. O grupo era formado por distintos cavalheiros provenientes de vários setores sociais sendo, em sua maioria, profissionais liberais. Gazeta Esportiva, 19 de janeiro de 1940, p. 13.

Nesse sentido, o presidente tricolor Décio Pedroso, os diretores Tomas Mauri, Eduardo de Almeida, Frederico Menzar, Roberto Pedrosa, Manuel Carlos Fineira e os membros do conselho, Carlos Monteiro Brisola e Tenente Porfírio da Paz encontraramse com o interventor federal em São Paulo, Fernando Costa, e conseguiram dele a 
promessa de ceder um terreno para a construção do seu campo esportivo ${ }^{369}$.

Analisar a transformação de um clube criado pelos setores populares para firmar uma identidade regionalista paulista dentro de um processo histórico que tentava unificar ideologicamente e territorialmente o país para uma entidade essencialmente elitista, pode auxiliar na compreensão de como o estado de São Paulo conseguiu voltar a ter seu espaço na esfera decisória do país.

${ }^{369}$ Correio Paulistano, 7 de setembro de 1941, p. 16 e Gazeta de Notícias, 7 de setembro de 1941, p. 7. 


\section{CONSIDERAÇÕES FINAIS}

Ao analisar a período estadonovista pelo futebol, procurou-se demarcar esse esporte como um elemento privelegiado para análise histórica como ritual misto e cotidiano na sociedade, espaço de representações e conflitos entre as diferentes classes sociais.

Assim, ao longo do texto, demonstrou-se como a ação controladora do regime encontrou no aspecto disciplinado e regrado do ludus um poderoso aliado para divulgar seus ideais de ordem, trabalho, unidade e harmonia social.

Em contrapartida, igualmente foi analisado como o caráter lúdico e libertário próprio da paidia presente no jogo de futebol possibilitou a existência de brechas para a resistência social. Esses espaços de tensão foram aproveitados pelas massas para contrariar o autoritarismo estadonovista e pelas elites deslocadas do poder que, por meio dessas áreas conflituosas, tentaram se recolocar no centro decisório nacional.

As concepções estilísticas de futebol-arte e futebol-força foram apresentadas no texto como construções derivadas do aspecto lúdico e agonístico do jogo com bola, respectivamente. O primeiro modelo foi construído destacando a alea própria do futebol em que o jogo seria praticado com liberdade, malandragem e individualidade. O futebol praticado com maior uniformidade tática, baseado na harmonia do conjunto e disciplina, destaca o agon do jogo com bola, próprio do segundo modelo estilístico.

Desse modo, foi destacado o modo como os dois aspectos próprios do ritual misto - a unifomização do coletivo (própria dos rituais burocráticos) e a liberdade e o poder gregário (base dos rituais comunitários) - foram trabalhados pelos diferentes grupos sociais, de acordo com seus interesses de classe.

Em diversos momentos, para o regime estadonovista era interessante destacar o 
aspecto burocrático do futebol e concretizar o modelo de futebol-força para melhor utilizar esse jogo na concretização de seus ideais. Em contrapartida, compreendeu-se como a massa exaltava a prática futebolística mais libertária, própria da construção estilística do futebol-arte e, pela preferência dada a essa forma de atuação conseguiu, por algumas vezes, contestar os valores do regime.

As narrativas presentes nos jornais de maior circulação dos estados de São Paulo e do Rio de Janeiro destacavam a tensão presente entre a ideologia estadonovista divulgada pela crônica esportiva e a sua recepção por uma massa trabalhadora ainda marcada pelos valores regionalistas e individualistas provenientes de antes do Estado Novo.

A escolha de periódicos como base documental da dissertação justificou-se pela visão da imprensa como meio de manipulação de interesses e intervenção na vida social. Assim, os jornais foram estudados como instrumentos de controle estatal e, concomitantemente, portadores de opiniões contraditórias aos projetos governamentais, ou seja, como espaço para a realização do embate tenso e conflituoso entre as diferentes classes sociais.

Apesar de a documentação consultada ter sido censurada pelo governo e constituir-se fruto da ideologia autoritária do regime, por ela conseguiu-se vislumbrar as fissuras do projeto estadonovista próprias do jogo entre diversos setores sociais na tentativa de se firmarem como dominantes.

As tensões existentes entre as diferentes classes sociais, o desconforto entre os valores projetados pelas elites e aqueles vivenciados cotidianamente pela massa, a utilização política e econômica do futebol pela classe dominante para firmar seus interesses e a utilização do espaço social proporcionado por esse esporte para ascenção e inserção popular ainda constituem pontos latentes na sociedade. 
Desse modo, finalizando a dissertação, destacou-se a importância de se realizarem outros estudos históricos sob a perspectiva de elementos próprios da cultura popular, como o futebol. Essa necessidade se justifica na medida em que, pela análise de como se processou a apropriação da cultura popular pela erudita, pode-se vislumbrar os conflitos, usos e interesses que ela sofreu em determinadas épocas e, assim, compreender não somente seus aspectos no passado, como sua influência no tempo presente. 


\section{BIBLIOGRAFIA CONSULTADA}

Fontes Primárias

- O periódico paulista Correio Paulistano, de novembro de 1937 a 1945;

- O periódico carioca Gazeta de Notícias, de novembro de 1937 ao final de 1941;

- O periódico carioca Jornal do Comércio, do início de 1942 ao final de 1945;

- O periódico Gazeta Esportiva, de São Paulo, desde novembro de 1937 a dezembro de 1945;

- O carioca Jornal dos Sports, de novembro de 1937 ao final de 1945;

- O acervo Futebol, no Museu da Imagem e do Som (MIS), de São Paulo. Foram contempladas todas as colaborações realizadas por profissionais ligados, direta ou indiretamente, ao futebol durante os anos de 1937 a 1945. 
Fontes Secundárias Específicas sobre Futebol

AGOSTINO, Gilberto. Vencer ou morrer. Futebol, geopolítica e identidade nacional. Rio de Janeiro: Faperj/ Mauad, 2002.

ANTUNES, Fátima Martin Rodrigues Ferreira. Com brasileiro não há quem possa. Crônicas de futebol e identidade nacional. Tese de Doutorado - FFLCH/ USP. São Paulo, 1999.

Futebol de fábrica em São Paulo. Dissertação de Mestrado - FFLCH/ USP. São Paulo, 1992.

CALDAS, Waldenyr. “Aspectos sócios políticos do futebol brasileiro”. Revista USP, $\mathrm{n}^{\circ}$ 22, p. 40-49, jun./jul./ago, 1994.

O pontapé inicial. Contribuição à memória do futebol brasileiro (1894-1933). Tese de Livre Docência - ECA/ USP. São Paulo, 1988.

CAMPOS, Flávio de. “Jogo de classes”. Folha de São Paulo. Entrevista concedida ao Mais! em 4 de dezembro de 2005.

CASTRO, Ruy (Org.). A sombra das chuteiras imortais. Crônicas de futebol. São Paulo: Companhia das Letras, 1993.

A Pátria em chuteiras. São Paulo: Companhia das Letras, 1994.

DAMATTA. Roberto (Org). Universo do Futebol. Esporte e sociedade brasileira. Rio de Janeiro: Pinakotheke, 1982.

DAMO, Arlei Sander. “Ah! Eu sou gaúcho! O nacional e o regional no futebol brasileiro”. Estudos Históricos. Rio de Janeiro, v. 13, n² 23, p. 87-117, 1999.

Do dom à profissão. Formação de futebolistas no Brasil e na França. São Paulo: Aderaldo \& Rothschild Editores/ Anpocs, 2007.

FAUSTO, Boris . "Política e futebol”. Folha de São Paulo. 26 de agosto de 2002. 
FLORENZANO, Jose Paulo. Afonsinho e Edmundo, a rebeldia no futebol brasileiro. São Paulo: Musa, 1998.

FOER, Franklin. Como o futebol explica o mundo. Rio de Janeiro: Jorge Zahar, 2005.

FRANCO JUNIOR, Hilário. A dança dos deuses: Futebol, cultura e sociedade. São Paulo: Companhia das Letras, 2007.

FRANZINI, Fábio. Corações da ponta da chuteira: capítulos iniciais da história do futebol brasileiro (1919 - 1938). Rio de Janeiro: DP\&A, 2003.

"Futebol é ‘coisa para macho’? Pequeno esboço para uma história das mulheres no país do futebol”. Revista Brasileira de História. São Paulo, vol. 25, n 50, pp. 315328, 2005.

GAMA, Walter. Aspectos socioculturais do futebolista. O caso do estado de São Paulo. Tese de Doutorado - ECA/ USP. São Paulo, 1996.

GASTALDO, Édison e GUEDES, Simoni L. Nações em campo. Niterói: Intertexto, 2006.

GIANOLI, Manuel Gustavo Manrique. Torcedor de futebol e o espetáculo da arquibancada: características da participação dos torcedores brasileiros em jogos de futebol. Dissertação de Mestrado - ECA/ USP. São Paulo, 1996.

GIUGLIANOTTI, Richard. Sociologia do futebol: dimensões históricas e socioculturais do esporte das multidões. São Paulo: Nova Alexandria, 2002.

GUEDES, Simoni Lahed. O Brasil no campo do futebol: Estudos antropológicos sobre os significados do futebol brasileiro. Niterói: EDUFF, 1998.

HELAL, Ronaldo e GORDON, César. "Sociologia, História e Romance na construção da identidade nacional através do futebol”. Estudos Históricos. Rio de Janeiro, v. 13, n ${ }^{\circ}$ 23, p. 147-165,1999.

HEPWORTH, Mike (Ed.). Football, violence and social identity. London/ New York: Routledge, 1994. 
JESUS, Gilmar Mascarenhas de. "Construindo a cidade moderna: a introdução dos esportes na vida urbana do Rio de Janeiro”. Estudos Históricos. Rio de Janeiro, v. 13, n 23, p. 17-39, 1999.

KLINTOWITZ, Jacob. “A implantação de um modelo alienígena exótico e outras questões pertinentes: a seleção brasileira de futebol - 1978”. Futebol e História. Encontros com a civilização brasileira, nº 5, nov., 1978.

LAVISORO, Martha e NEVES, Lecy. Futebol e sociedade. Um olhar transdisciplinar. Rio de Janeiro: Editora UERJ, 2005.

LOPES, José S. Leite. “A vitória do futebol que incorporou a pelada”. Revista USP. São Paulo: v. 22, jun/ jul/ ago, 1994.

LYRA, João Filho. Introdução à Sociologia dos Desportos. Rio de Janeiro: Editora e Edições Bloch, 1973.

MARQUES, José Carlos. O futebol em Nelson Rodrigues. O óbvio ululante, o Sobrenatural de Almeida e outros temas. São Paulo: Educ/ Fapesp, 2003.

MAZZONI, Thomas (Olimpicus). História do Futebol no Brasil, 19894-1950. São Paulo: Editora Leia, 1950.

MEIHY, José Carlos Sebe Bom e WITTER, José Sebastião (Orgs.). Futebol e Cultura Coletânea de estudos. Convênio IMESP/DAESP. Imprensa Oficial: Arquivo de Estado. São Paulo, 1982.

MILAN, Betty. O país da bola. Rio de Janeiro: Record, 1998.

MURRAY, Bill. Uma história do futebol. São Paulo: Hedra, 2000.

NEGREIROS, Plínio José Labriola de Campos. A nação entra em campo: Futebol nos anos 30 e 40. Tese de Doutorado - História/ PUC-SP. São Paulo, 1998.

PEREIRA, Leonardo. Footballmania. Uma história social do futebol no Rio de Janeiro, 1902-1938. Rio de Janeiro: Nova Fronteira, 2000.

PIMENTA, Carlos Alberto Máximo. Torcidas organizadas de futebol. Violência e autoafirmação, aspectos da construção das novas relações sociais. Taubaté: Vogal Editora, 
1997.

PRADO, Décio de Almeida. Seres, coisas, lugares. Do teatro ao futebol. São Paulo: Companhia das Letras, 1997.

RAMOS, Roberto. Futebol. Ideologia do poder. Petrópolis: Vozes, 1984.

RODRIGUES FILHO, Mario. O negro no futebol brasileiro. $4^{\mathrm{a}}$ edição. Rio de Janeiro: Mauad, 2003.

ROSENFELD, Anatol. Negro, macumba e futebol. São Paulo: Edusp/ Perspectiva/ Editora da Unicamp, 1993.

SALDANHA, João. Os subterrâneos do futebol. $2^{\circ}$ ed. Rio de Janeiro: Editora José Olympio, 1980.

SALUN, Alfredo Oscar. Palestra Itália e Corinthians: Quinta coluna ou tudo buena gente? Tese de Doutorado - FFLCH/ USP. São Paulo, 2007.

SANTOS, Joel Rufino dos Santos. "Na CBD até o papagaio bate continência". Futebol e História. Encontros com a civilização brasileira, nº 5, nov., 1978.

SANTOS NETO, José Moraes dos. Visão do jogo. Primórdios do futebol no Brasil. São Paulo: Cosac \& Naify, 2002.

SEBRELI, Juan José. La era del fútbol. 1ª ed. Buenos Aires: Debolsillo, 2005.

SEVCENKO, Nicolau. “Futebol, metrópoles e desatinos”. Revista USP, nº 22, p. 30-37, jun./jul./ago, 1994.

SILVA, Francisco Teixeira da e SANTOS, Ricardo Pinto dos (Orgs.). Memória social dos esportes: a construção de uma identidade nacional. Vol. 2. Rio de Janeiro: Mauad Editora, 2006.

SOARES, Antônio Jorge. "História e invenção de tradições no campo de futebol". Estudos Históricos. Rio de Janeiro, v. 13, n 23, p. 119-146, 1999. 

173, 1999.

“A modo de resposta”. Estudos Históricos. Rio de Janeiro, v. 13, n 23, p. 166-

TOLEDO, Luíz Henrique de. Lógicas no futebol. Dimensões simbólicas de um esporte nacional. Tese de Doutorado - Antropologia Social/ USP. São Paulo, 2000.

Torcidas Organizadas de Futebol. Col. Educação Física e Esportes. Campinas: Autores Associados/ Anpocs, 1996.

. "Transgressão e violência entre torcedores de futebol”. Revista USP, $\mathrm{n}^{\mathrm{0}}$ 22, p. 92-101, jun./jul./ago, 1994.

WISNIK, José Miguel. Veneno remédio. O futebol e o Brasil. São Paulo: Companhia das Letras, 2008.

WITTER, José Sebastião. Futebol, presente, passado e futuro. Caderno Paulista XLIII. São Paulo, nº 20, p. 2-8, 11 de novembro de 2002.

.O futebol e a paulicéia. Cadernos de história de São Paulo, n ${ }^{\circ}$ 5, p. 55-59, set./nov., 1996.

O futebol no campo da história. Congresso de História na região do Grande ABC. Santo André, p. 30-38, 1990.

O que é futebol. Coleção primeiros passos. São Paulo: Editora Brasiliense, s.d. 
Fontes Secundárias Específicas sobre Estado Novo

ALMEIDA JR, Antonio Mendes de. "Do declínio do Estado Novo ao suicídio de Getúlio Vargas”. IN: FAUTO, Boris (Org.). História Geral da civilização Brasileira. T. III, v. 3. Cap. IV. O Brasil Republicano. Sociedade e Política (1930-1964). São Paulo: Difel, 1981.

CARONE, Edgar. Brasil: Anos de crise 1930-1945. Série fundamentos, 77. São Paulo: Ática, 1991. A Terceira República. Col. Corpo e Alma do Brasil. São Paulo: Difel, 1976.

CHACON, Vamireh. Estado e Povo no Brasil. As experiências do Estado Novo e da Democracia Populista: 1937-1964. Col. Documentos Brasileiros, v. 181. Rio de Janeiro/ Brasília: José Olympio/ Câmara dos deputados, 1977.

DINIZ, Eli. “O Estado Novo: Estrutura de poder, relações de classes”. IN: FAUTO, Boris (Org.). História Geral da civilização Brasileira. T. III, v. 3. Cap. II. O Brasil Republicano. Sociedade e Política (1930-1964). São Paulo: Difel, 1981.

DINIZ FILHO, Luis Lopes. Território e destino nacional: Ideologias geográficas e políticas territoriais no Estado Novo (1937-1945). Dissertação de Mestrado - FFLCH/ USP. São Paulo, 1993.

GUIMARÃES, Silvana Goulart. Ideologia, propaganda e censura no Estado Novo. Dissertação de Mestrado - FFLCH/ USP. São Paulo, 1984.

HENRIQUES, Affonso. Ascensão e queda de Getúlio Vargas: Vargas e o Estado Novo. Vol. 1 e 2. Rio de Janeiro: Record, 1966.

MELO e SOUZA, José Inácio. A ação e o imaginário de uma ditadura: controle, coerção e propaganda política nos meios de comunicação durante o Estado Novo. Dissertação de Mestrado - USP. São Paulo, 1990.

OLIVEIRA, Lúcia Lippi, VELLOSO, Mônica Pimenta e GOMES, Ângela Maria Castro. Estado Novo. Ideologia e Poder. Rio de Janeiro: Zahar Editores, 1982. 
PANDOLFI, Dulce (Org.). Repensando o Estado Novo. Rio de Janeiro: Ed. Fundação Getulio Vargas, 1999. Versão online: www.cpdoc.fgv.br

SOLA, Lourdes. “O golpe de 1937 e o Estado Novo”. IN: MOTA, Carlos Guilherme (Org.). Brasil em perspectiva. Coleção Corpo e Alma do Brasil. São Paulo: Difusão Européia do Livro, 1969.

TOTA, Antonio Pedro. O Estado Novo. Col. Tudo é História, vol. 114. $4^{\circ}$ ed. São Paulo: Editora Brasiliense, 1994.

VARGAS, Getúlio. Diário. Vol. II. São Paulo/ Rio de Janeiro: Siciliano/ Fundação Getúlio Vargas, 1995. 
Fontes Secundárias de Referências Políticas

CAMARGO, Aspácia de Alcântara Camargo. “A questão agrária: crise de poder e reformas de base (1930-1964)”. IN: FAUTO, Boris (Org.). História Geral da civilização Brasileira. T. III, v. 3. Cap. III. O Brasil Republicano. Sociedade e Política (1930-1964). São Paulo: Difel, 1981.

CAPELATO, Maria Helena Rolim. Multidões em cena. Propaganda política no Varguismo e no Peroinismo. Campinas: Papirus, 1998.

CHAUÍ, Marilena. “Apontamentos para uma crítica da ação integralista brasileira”. IN: CHAUÍ, Marilena e FRANCO, Maria Sylvia Carvalho. Ideologia e mobilização popular. Rio de Janeiro: Paz e Terra, 1978.

CYTRYNOWICZ, Roney. Guerra sem guerra. A mobilização e o cotidiano em São Paulo durante a Segunda Guerra Mundial. São Paulo: Geração Editorial /Edusp, 2000.

FERREIRA, Jorge (Org). O populismo e sua história: debate e crítica. Rio de Janeiro: Civilização Brasileira, 2001.

FERRETTI, Danilo José Zioni. A construção da paulistanidade. Identidade, historiografia e política em São Paulo (1856-1930). Tese de Doutorado - FFLCH/ USP. São Paulo, 2004.

GAMBINI, Roberto. O duplo jogo de Getúlio Vargas. São Paulo: Símbolo, 1977.

GIRARDET, Raoul. Mitos e mitologias políticas. São Paulo: Companhia das Letras, 1987.

IANNI, Octávio. O colapso do populismo no Brasil. $2^{\circ}$ ed. Rio de Janeiro: Editora Civilização Brasileira, 1971.

Estado e planejamento econômico no Brasil (1930-1970). $3^{\circ}$ ed. Rio de Janeiro: Editora Civilização Brasileira, 1979. 
Industrialização e desenvolvimento social no Brasil. Rio de Janeiro: Editora Civilização Brasileira, 1963.

JAMBEIRO, Othon (Org). Tempos de Vargas: o rádio e o controle da informação. Salvador: EDUFBA, 2004.

LEAL, Victor Nunes. Coronelismo, enxada e voto. São Paulo: Editora Alfa-Ômega, 1975.

LENHARO, Alcir. Sacralização da política. 2a ed. Campinas: Papirus, 1986.

MANHÃES, Eduardo Dias. Políticas de Esportes no Brasil. Rio de Janeiro: Graal, 1986.

MARTINS, Heloisa Helena Teixeira de Souza. O Estado e a burocratização do sindicato no Brasil. 2a ed. São Paulo: Editora Hucitec, 1989.

RAIMUNDO, Silvia Lopes. A invenção do mito bandeirante. Tradição e pensamento regionalista na historiografia paulista nas décadas de 1920-1930. Dissertação de Mestrado - FFLCH/ USP. São Paulo, 2001.

RODRIGUES, Leôncio Martins. "Sindicalismo e classe operária (1930-1964)". IN: FAUTO, Boris (Org.). História Geral da civilização Brasileira. T. III, v. 3. Cap. X. O Brasil Republicano. Sociedade e Política (1930-1964). São Paulo: Difel, 1981.

SAES, Décio A M. “Classe média e política no Brasil 1930-1964”. IN: FAUTO, Boris (Org.). História Geral da civilização Brasileira. T. III, v. 3. Cap. IX. O Brasil Republicano. Sociedade e Política (1930-1964). São Paulo: Difel, 1981.

SCHEMES, Claudia. As festas cívicas e esportivas no populismo. Um estudo comparado dos governos Vargas (1937-1945) e Perón (1946-1955). Dissertação de Mestrado - FFLCH/ USP. São Paulo, 1995.

SKIDMORE, Thomas E. Brasil: de Getúlio Vargas a Castelo Branco (1930-1964). Rio de Janeiro: Paz e Terra, 1975.

TOTA, Antônio Pedro. O imperialismo sedutor: a americanização do Brasil na época da Segunda Guerra. São Paulo: Companhia das Letras, 2000. 
VARGAS, Getúlio. A nova política do Brasil. Livro V- O Estado Novo (10 de novembro de 1937 a 25 de julho de 1938). Rio de Janeiro: Livraria José Olympio Editora, 1938.

VIANNA, Luis Werneck. Liberalismo e sindicato no Brasil. $2^{\mathrm{a}}$ ed. Rio de Janeiro: Paz e terra, 1978.

WEFFORT, Francisco Correa. O populismo na política brasileira. Rio de Janeiro: Paz e Terra, 1980. 
Fontes Secundárias de Referências Teóricas

ALTHUSSER, Louis. Ideologia e Aparelhos Ideológicos do Estado. $2^{\circ}$ ed. Rio de Janeiro: Edições Graal, 1985.

ANDERSON, Benedict. Comunidades imaginadas: reflexões sobre a origem e a difusão do nacionalismo. São Paulo: Companhia das Letras, 2008.

. Nação e consciência nacional. São Paulo: Ática, 1989.

BERCITO, Sonia de Deus Rodrigues. Ser forte para fazer a nação forte. A educação física no Brasil (1932-1945). Dissertação de Mestrado - FFLCH/ USP. São Paulo, 1991.

BOURDIEU, Pierre. A economia das trocas simbólicas. São Paulo: Perspectiva, 2005. Programa para uma sociologia do esporte. IN: BOURDIEU, Pierre. Coisas ditas. São Paulo: Ed. Brasiliense, 2004.

Como é possível ser esportivo?
sociologia. Rio de Janeiro: Marco Zero, 1983.

CAILLOIS, Roger. Los juegos y los hombres. La máscara y el vértigo. México: Fondo de Cultura Económica, 1986.

CAMARGO, Ana Maria de Almeida. A imprensa periódica como objeto e instrumento de trabalho. Catálogo da Hemeroteca Júlio Mesquita do Instituto Histórico e Geográfico de São Paulo. Tese de Doutorado - FFLCH/ USP. São Paulo, 1975.

CAPELATO, Maria Helena Rolim. Os arautos do liberalismo: Imprensa paulista 19201945. São Paulo: Brasiliense, 1988a.

Os intérpretes das luzes. Liberalismo e imprensa paulista; 1920-1945. Tese de Doutorado - FFLCH/ USP. São Paulo, 1986.

Imprensa e História do Brasil. Col. Repensando a História. $2^{\circ}$ ed. São Paulo: Ed. da Universidade de São Paulo, 1988b. 
CAPELATO, Maria Helena Rolim e PRADO, Maria Lígia. O Bravo Matutino. Imprensa e ideologia: O Jornal "O Estado de São Paulo”. São Paulo: Alfa-Ômega, 1980.

CHALHOUB, Sidney. Cidade Febril - cortiços e epidemia na corte imperial. São Paulo: Companhia das Letras, 1996.

CHARTIER, Roger. A historia cultural. Entre práticas e representações. Lisboa: Difel, 1990.

DAMATTA. Roberto. Carnavais, malandros e heróis. Para uma sociologia do dilema brasileiro. $4^{\circ}$ ed. Rio de Janeiro: Zahar Editores, 1983.

DURKHEIM, Emile. As formas elementares da vida religiosa. Os sistemas totêmicos na Austrália. São Paulo: Martins Fontes, 1996.

DUVIGNAUD, J. El juego del juego. México: Fundo de Cultura Econômica, 1982.

ELIAS, Nobert. O processo civilizador. v. 2. Rio de Janeiro: Zahar, 1994.

ELIAS, Norbert e DUNNING, Eric (Orgs.). A busca de excitação. Col. Memória e Sociedade. Lisboa: DIFEL, 1992a.

Deporte y ocio en el proceso de la civilizacion. México: Fondo de Cultura Económica, 1992b.

GEERTZ, Clifford. A interpretação das culturas. Rio de Janeiro: Guanabara Koogan, 1989.

HOBSBAWM, Eric J. Nações e nacionalismos desde 1780. Programa, mito e realidade. $5^{\circ}$ ed. São Paulo: Paz e Terra, 2008.

HOLANDA, Sérgio Buarque. Raízes do Brasil. 26º ed. São Paulo: Companhia das Letras, 1995. 
HORKHEIMAR, Max e ADORNO, Theodor. Temas básicos da sociologia. São Paulo: Editora Cultrix, 1983.

HUIZINGA, Johan. Homo Ludens. O jogo como elemento da cultura. $5^{\circ}$ ed. São Paulo: Perspectiva, 2005.

LEITE, Dante Moreira. O caráter nacional brasileiro: história de uma ideologia. $4^{\mathrm{a}}$ ed. São Paulo: Pioneira, 1983.

MARCUSE, Herbert. A ideologia da sociedade industrial. Rio de Janeiro: Zahar, 1969.

MAUSS, Marcel. Sociologia e antropologia. Rio de Janeiro: Cosac \& Naify, 2003.

MERDRIGNAC, Bernard. Le sport au Moyen Âge. Rennes: Presses Universitaires de Rennes, p. 215-232, 2002.

MOTA, Carlos Guilherme. Ideologia da cultura brasileira (1933-1974). $4^{\circ}$ ed. São Paulo: Ática, 1978.

NASCIMENTO, Luciana. "De vitrines e multidões: O nascimento do espaço urbano moderno”. Temas \& matrizes, $\mathrm{n}^{\circ} 8,2^{\circ}$ semestre de 2005.

NOVAIS, Fernando A. (Coord.). História da vida privada no Brasil. 3 vol. São Paulo: Cia dos Livros, 1998.

ORTIZ, Renato. Cultura brasileira e identidade nacional. São Paulo: Brasiliense, $5^{\circ}$ ed. 1994.

RESENDE, Beatriz e VALENÇA, Rachel (Orgs.). Toda Crônica. Rio de Janeiro: Agir, 2004.

RUDÉ, George. A multidão na história: estudo dos movimentos populares na França e Inglaterra, 1730-1848. Rio de Janeiro: 1991. 
SOARES, Edileuza. A bola no ar. O rádio esportivo em São Paulo. São Paulo: Summus, 1994.

SODRÉ, Nelson Werneck. A história da Imprensa no Brasil. $4^{\circ}$ ed. Rio de Janeiro: Mauad, 1999.

SUROWIECKI, James. A sabedoria das multidões. Rio de Janeiro: Record, 2006.

VESENTINI, Carlos Alberto. Teia do fato: uma proposta de estudo sobre a memória histórica. Tese de Doutorado, FFLCH/ USP. São Paulo, 1982. 
